\section{НОВАЯ НАУКА}

Международный центр научного партнерства
NEW SCIENCE

International Center for Scientific Partnership

\author{
А. И. Прищепа
}

\title{
ГОРОДСКОЕ СТРОИТЕЛЬСТВО В ХАНТЫ-МАНСИЙСКОМ АВТОНОМНОМ ОКРУГЕ - ЮГРЕ (к.1950-х - сер.1990-х гг.)
}

Монография

г. Петрозаводск

МЦНП «Новая наука»

2021 


\author{
Aв Top: \\ Прищепа Александр Иванович \\ доктор исторических наук, профессор, \\ Почетный профессор Сургутского государственного университета ХМАО-Югры, \\ Заслуженный деятель науки Ханты-Мансийского автономного округа-Югры, \\ Почетный работник Высшего профессионального образования \\ Российской Федерации
}

\title{
Рецензенты:
}

\section{Карпов В. П.}

доктор исторических наук, профессор кафедры гуманитарных наук и технологий Тюменского индустриального университета, Почётный работник сферы образования Российской Федерации

Корнилов Г. Е.

доктор исторических наук, профессор, заведующий центром экономической истории института Истории и археологии УРО РАН, Заслуженный деятель науки Российской Федерации

\section{Прищепа, Александр Иванович.}

П77 Городское строительство в Ханты-Мансийском автономном округе Югре (к.1950-х - сер.1990-х гг.) : Монография / А. И. Прищепа. Петрозаводск : МЦНП «Новая наука», 2021. - 221 с.: рис., табл.

ISBN 978-5-00174-041-4

DOI 10.46916/02022021-978-5-00174-041-4

В монографии реконструируется история градостроения в Ханты-Мансийском автономном округе - Югре в годы его интенсивного нефтегазового освоения. В центре внимания автора находятся проблемы проектно-изыскательской и архитектурной работы, поиска эффективных путей создания индустрии строительных материалов и совершенствования технологии строительства, природоохранной деятельности на территории Западно-Сибирского нефтегазового комплекса.

Большое внимание уделяется исследованию социальной проблематики застройки новых «нефтяных городов», включающему оценку отраслевой системы организации и управления жилищным и гражданским строительством, а также характеристику повседневной жизни рабочих и служащих этой отрасли экономики ХМАО-Югры.

Книга может быть полезна профессиональным исследователям, преподавателям гуманитарных дисциплин общеобразовательных учреждений, всем интересующимся историей своей малой родины. 


\section{ОГЛАВЛЕНИЕ}

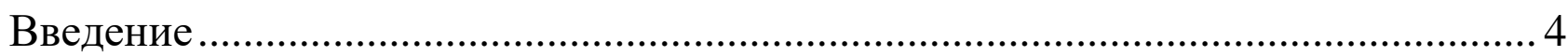

Глава 1. Проектно-изыскательская работа на севере

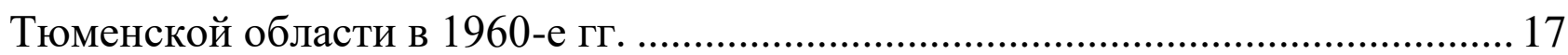

Глава 2. Деятельность проектировщиков и архитекторов

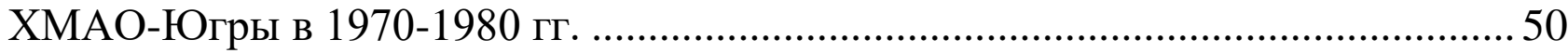

Глава 3. Развитие местного производства строительных материалов ................. 66

Глава 4. Главк «Главтюменнефтегазстрой»

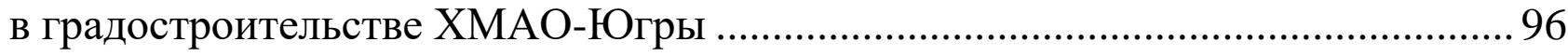

Глава 5. Жилищное строительство в новых северных городах........................... 139

Глава 6. Благоустройство новых северных городов ............................................ 183

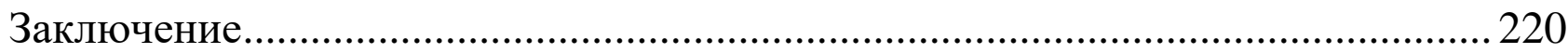




\section{ВВЕДЕНИЕ}

В многовековой истории России Югре была предопределена особая роль.

Коренное население этого далекого северного края многие годы являлось поставщиком «мягкого золота» - пушнины, составлявшей значительную часть бюджета Русского государства того времени.

В конце XV-XVII вв. новые северные города сыграли решающую роль в освоении территорий на Востоке, оснащая и благословляя на подвиг отряды первопроходцев, шедших за Камень до Тихого океана, - Россия прирастала Сибирью.

Однако по мере перемещения главной восточной транспортной траектории на юг северные города Западной Сибири стали утрачивать своё былое военно-административное и хозяйственного значение. С начала XVIII и фактически до середины XX века они стали представлять собой заштатные сибирские городки с населением от 500 до 2000 человек и являлись местом ссылки военнопленных, бунтовщиков и преступников. Основными занятиями жителей были рыболовство, охота, торговля с коренными жителями. В начале $\mathrm{XX}$ века в связи с малочисленностью их населения за ними официально был закреплен статус районных сел. Сургут и Березово, например, стали таковыми в 1926 году.

После ухода пионеров сибирского градостроения со сцены активного государственного действа России историческая память о них была разбужена громом газовых и нефтяных месторождений в Березово, Шаиме, Мегионе и Усть-Балыке в 1950-х - начале 1960-х гг.

Эти сенсационные открытия свидетельствовали о том, что в силу ряда географических и природно-климатических факторов в недрах Югры оказались сосредоточенными огромные, еще окончательно не определенные учеными запасы углеводородного сырья, вовлечение которых в промышленный оборот в значительной мере могло стать решающим фактором экономического роста и укрепления геополитического и военно-стратегического потенциала страны.

Главную роль при этом должно было сыграть социальное освоение географически удаленной, заболоченной, лишенной транспортных коммуникаций, находящейся в районе с экстремальными климатическими условиями территории. Градостроение призвано было стать решающим фактором достижения этой цели. 
Ареал строительства городов новой нефтегазоносной провинции очерчен современной территорией ХМАО - Югры. Однако в силу указанных причин на этой территории невозможно было создать стартовую площадку динамично развивающейся промышленности строительных материалов, которую целесообразно было дислоцировать южнее, на территории Тюменской области.

Поэтому региональные рамки нашего исследования включают и территорию Тюменской области, с которой отношения Югры с момента вхождения округа в ее состав в 1944 году всегда строились на принципах согласованности, активного социально-экономического сотрудничества и достижения взаимного благополучия.

Сегодня актуальность данной темы исторического исследования предопределяется необходимостью использования накопленного в ходе освоения севера Западной Сибири его апробированного опыта, нашедшего применение и признание эффективных форм и методов организации и управления городским строительством, развития его материальной базы, совершенствования технологических процессов и качества работ, создания благоприятной городской среды, поиска иных форм расселения трудовых ресурсов. Он может стать реальным вкладом в градостроительную теорию и практику решения современной стратегической задачи освоения арктического побережья Урала и Западной Сибири.

Наряду с актуальностью и практической значимостью представляемого исследования особо следует указать на номологическое значение данной монографии. Автор стремился экспонировать её в результате изучения ранее не исследованной проблематики этой плодотворной темы и введения в научный оборот аналогичных исторических источников. С этой точки зрения данное исследование представляет собой попытку первого специального комплексного изучения истории городского строительства в ХМАО-Югре.

Вместе с тем в работе использованы некоторые переработанные и дополненные фрагменты изданной автором в 2015 году книги «Возрождение Сургута. Вторая половина XX века».

Первые подходы к изучению данной проблемы относятся ко второй половине 1960-х гг. Знаменательно, что в когорте первооткрывателей междисциплинарного изучения этой пионерной темы достойное место занимали и историки. Первоначально градостроение рассматривалось ими в контексте изучения нефтегазоносной проблематики, из полифонического 
многообразия которой с течением времени развилось и оформилось самостоятельное научное направление.

Эстафетную палочку на старте формирования исторического нарратива градостроения на севере Тюменской области естественным образом первыми взяли в свои руки ученые западносибирских вузов. Среди них, прежде всего, следует назвать тюменского историка Б.А. Нима (1). Он не ставил в качестве предмета своего исследования изучение проблем градостроения в Западной Сибири. Его научной заслугой является инициирование изучения открытия и становления новой нефтегазоносной провинции, первое обоснование периодизации этого процесса, приобщение историков к научной проблематике нового направления сибирской историографии.

Достойным преемником изучения этой новаторской темы стал Н.М. Пашков, который в 1988 году защитил диссертацию на соискание ученой степени кандидата исторических наук. Его работа представляла собой плодотворный исследовательский опыт исторического осмысления западносибирского нефтегазового феномена (2).

Несмотря на характерную для историко-партийных работ того времени идеологическую риторику, необходимо признать несомненную научную ценность представленной работы Н.М. Пашкова. Автору удалось объективно показать не только непосредственный процесс нефтегазового освоения гигантской сибирской энергетической провинции, но и отметить роль социальных факторов в решении этой задачи, в числе которых градостроение занимало решающее место. Новая, открытая и введенная тюменскими историками в научный оборот проблематика оказалась неожиданной и долгое время не получала продолжения своего изучения.

Неслучайно поэтому то, что вслед за выходом в 1988 году упомянутой работы последовала некая исследовательская пауза. Ученые задумались о концептуальной перспективе последующего масштабного изучения ЗападноСибирского нефтегазового комплекса, в том числе и о его «эмбрионе» градостроительной политике на севере Тюменской области.

Только через семь лет «нефтяная тематика» начала возвращаться на страницы исторических изданий, впоследствии заняв свое достойное место в сибирской историографии новейшей истории региона. Это произошло благодаря защите кандидатской диссертации начинающего тогда свой творческий путь молодого ученого С.М. Панарина. Искренне восприняв провозглашенную политику гласности и декларированную свободу научного 
творчества, в своей кандидатской диссертации он дал смелую критическую оценку социальной политике КПСС в годы нефтяного бума 1970-х гг.

Опираясь на официальные источники, автор недвусмысленно нарисовал печальную объективную картину жизнедеятельности нефтяников, в том числе затронув и вопросы повседневного социально-бытового функционирования новых сибирских городов (3).

Обсуждение диссертации С.М. Панарина сопровождалось плодотворной полемикой в Диссертационном Совете Уральского государственного университета, и в условиях набиравшего силу методологического реформирования 1990-х гг. соискателю удалось успешно защитить кандидатскую диссертацию.

После этого социально окрашенного и заостренного, но достаточно фрагментарного изложения научной позиции по градостроительному вопросу в его изучении вновь наступает некоторый перерыв. В 1999 году очередное опосредованное обращение к теме градостроительства мы наблюдаем в работе Н.Ю. Гавриловой, изданной в формате исследования социальной политики на севере Сибири в годы создания Западно-Сибирского нефтегазового комплекса. Такой экскурс в историю градостроения в исследуемом регионе был необходим в контексте создания комплексной ретроспективной картины повседневной жизни сибирских нефтяников и газовиков. В изданной статье «Градостроительная концепция освоения нефтедобывающих районов Западной Сибири и ее реализация (1960-1980-е гг.)» автор, специально не рассматривая вопросы политики и практики градостроения, вновь ориентирует внимание ученых на приоритетные исследовательские подходы к истории городского строительства на севере Тюменской области (4).

В дальнейшем основные идеи этой статьи получили плодотворное развитие в содержательной монографии Н.Ю. Гавриловой «Социальное развитие нефтегазодобывающих районов Западной Сибири (1964-1985-е гг.), где автор сумела показать социальные факторы, повлиявшие на принятие модели расселения рабочих кадров на территории нового нефтегазового освоения.

Большое значение имеет и обоснование Н.Ю. Гавриловой некоторых специфических черт создания индустрии строительства на севере Тюменской области, детерминированных природно-географическими условиями. Однако комплексная оценка градостроительной политики и практики в упомянутых работах отражения не получила (5). 
Развивая эту проблематику, в 2002 году Н.Ю. Гаврилова и В.П. Карпов опубликовали статью «Жилищно-гражданское строительство в районах нового промышленного освоения Севера Западной Сибири», где авторы одними из первых показали динамику городской застройки северных поселений в связи с промышленным освоением их территорий. Они ввели в научный оборот достаточно интересный фактический материал, характеризующий проблемы северной жилищной застройки. Вместе с тем основная системообразующая проблематика градостроения, связанная с анализом проектно-изыскательского, материально-технического, кадрового, социально-бытового обеспечения не входила в задачи авторитетных тюменских историков и поэтому по-прежнему оставалась вне поля научного изучения (6).

В последующие годы сосредоточенное внимание этих исследователей на вопросах экономической и социальной политики в нефтедобывающих районах Западной Сибири реализовалось в публикации содержательной работы «Курс истории отечественной нефтяной и газовой промышленности», где в одном из ее разделов авторы на новом уровне возвратились к анализу градостроительной политики на территории Западно-Сибирского нефтегазового комплекса и аргументированно показали особенности демографических процессов в нефтедобывающих районах, их влияние на формы организации труда нефтяников и газовиков, эволюцию модели расселения мигрирующего населения на севере Западной Сибири во второй половине XX века. Н.Ю. Гаврилова и В.П. Карпов в этой работе косвенно затронули вопросы социальных и геофизических причин трудностей проектно-изыскательских работ на севере Западной Сибири, формирования здесь архитектурного образа новых городов, создания для их строительства необходимой индустриальной строительной базы. Несомненной заслугой авторов является акцентирование внимания на ведомственном характере застройки северных городов Тюменской области как главного тормозящего фактора успешного развития этого процесса (7).

Традиционная широкая постановка вопросов промышленного и социального освоения Западно-Сибирской нефтегазовой провинции ориентировала на изучение истории жилищного строительства на севере области и других тюменских историков. Так, например, особенности расселения рабочих кадров на севере Тюменской области в годы создания Западно-Сибирского нефтегазового комплекса нашли отражение в работе Г.Ю. Колевой и Ж.М. Колева «Хозяйственное освоение Западной Сибири и ее 
заселение в разные исторические периоды», в которой авторы сумели показать взаимную обусловленность промышленного и гражданского строительства в процессе нефтегазового освоения новой энергетической провинции, обратив при этом специальное внимание на экономическую эффективность модели стационарного расселения трудовых ресурсов в контексте перспективного социального развития территории Западно-Сибирского нефтегазового комплекса (8).

Однако при всей актуальности и научной значимости опубликованных работ ведущих тюменских историков следует отметить, что они не ставили, за исключением статьи Г.Ю. Колевой «Строительство городов в районах нового промышленного освоения в 1960-1980-е гг.» (9), в качестве основной задачи комплексное освещение истории градостроения на севере Западной Сибири. Вопросы строительства городов на этой территории затрагиваются ими в контексте общей оценки реализации социальной политики на севере Тюменской области и не претендуют на всестороннюю репрезентативность сциентической оценки проблем сибирского градостроения в исследуемый период.

Определенным компенсатором вакуума научных исследований истории гражданского и жилищного строительства в годы создания ЗСНГК является книга Г.Ю. Колевой «Западно-Сибирский нефтегазовый район: экономическое и социальное развитие (1960-2000 гг.)», особенно вторая часть ее монографии «Западно-Сибирский нефтегазовый комплекс: история становления», где в контексте истории промышленного развития края представлен интересный фактический материал по формированию индустриальной базы и кадрового потенциала строительной отрасли в регионе (10).

В этой связи необходимо обратить внимание на работу Н.П. Розанова «Крупнопанельное домостроение», изданную в Москве в 1982 году, где автор прослеживает историю становления индустрии жилищного домостроения в СССР и показывает процесс его развития в Западной Сибири (11).

На наш взгляд, весьма глубокое изучение градостроительной политики в Западной Сибири ассоциируется с публикациями тюменского историка И.Н. Стася. Обратившись к исследованию этой темы с широкого проблемного замера изучения процессов урбанизации на севере Западной Сибири, он опубликовал весьма содержательные статьи, посвященные ряду актуальных вопросов, включающих проблемы форм расселения прибывающих на север трудовых ресурсов, отраслевого управления строительством, впечатляющего 
круга демографической тематики, проектирования и строительной практики новых городов. Тем самым автор одним из немногих представителей сибиреведческой исторической науки определенно расставил ориентиры последующего исследования истории градостроения в Западной Сибири (12).

Монография И.Н. Стася «От поселков к городам и обратно» (13), вышедшая в 2016 году, является одним из первых шагов на пути системного изучения истории «советской урбанизации» Сибири с упором на ее специфику. Она вносит весомый вклад в дальнейшее комплексное изучение дискуссионного вопроса об особенностях урбанизации Сибири, включающего продолжающийся острый обмен мнениями об эффективности форм расселения, осуществления современной стратегии градостроения в районах ХантыМансийского автономного округа, проблемах его проектно-архитектурного пространства и демографической разверстки территории края.

Весьма ценным в связи с последним тезисом для историографии сибирской урбанистики является издание И.Н. Стасем в 2018 году монографии «Стать горожанином: урбанизация и население в нефтяном крае», в которой автор раскрывает тенденции демографического развития округа и тем самым открывает новую страницу в научном осмыслении процесса градостроения в Ханты-Мансийском автономном округе - Югре (14).

Многоаспектное содержание процесса градостроения неумолимо побуждало историков к более широкой исследовательской экспансии проблемного поля предмета исследования. Попытка акцентированного выражения диалектики урбанизационных процессов и формирования системы городского расселения в нефтедобывающих районах Тюменской области нашла отражение в монографии Г.Ю. Колевой, И.Н. Стася и И.И. Шороховой «Становление индустриально-урбанистического общества на территории Тюменской области» (15). Определив нижним рубежом своего исследования XVI век, авторы показали особенности заселения Сибири на разных этапах ее колонизации, сконцентрировав внимание в его финале на плодотворной методологической идее, заключающейся в единстве триады: промышленное освоение, урбанизация, градостроение на территории севера Западной Сибири.

В ходе подготовки нашего исследования мы опирались на традиционные исторические источники, представленные преимущественно архивными документами Государственного архива социально-политической истории Тюменской области (ГАСПИТО): Ф.107, Ф.113, Ф.124; Государственного архива Тюменской области (ГАТО): Ф.1731, Ф.1861, Ф.1933; Архивного отдела 
администрации города Сургута (АОАГС): Ф.1, Ф.3, Ф.34, Ф.71, Ф.80,Ф.90; Государственного архива Ханты-Мансийского автономного округа (ГАХМАО); Архивного отдела администрации города Нижневартовска (АОАГН): Ф.48/160л. 620 ед.хр.1971-2002 гг.; Ф.25/129-л.212 ед.хр.1986-1998 гг.; Ф.80-л.261 ед.хр.1973-2000 гг. и другие.

Стремясь не обременять наше исследование излишней академической официозностью и придать ему по возможности более публичный характер, мы старались ввести в научный оборот максимальное количество мемуарной литературы, имея в виду возросшую актуальность социальноантропологического подхода. При этом обнаружилось, что краеведческая и мемуарная литература, посвященная различным проблемам развития городов Югры, содержит весьма важные факты для восстановления истории их строительства (16). В этом разнообразном жанровом круге локальной истории отметим документальную повесть М.К. Юрасовой и Г.М. Юрасовой, которым удалось, на наш взгляд, наиболее полно показать вклад В.И. Муравленко в новейшую историю городов Тюменского севера (17).

Особенно ценный материал, с этой точки зрения, для нашего исследования представляют содержательные воспоминания непосредственных участников грандиозной строительной эпопеи, развернувшейся во второй половине XX века на территории Западной Сибири. В воспоминаниях В.А. Бешкильцева, П.А. Мунарева, В.В. Бахилова, В. Бирюкова, И.П. Захарова, Ф.Я. Показаньева и некоторых других мемуаристов, внесших непосредственный неоценимый вклад в сибирское краеведение, мы находим уникальные свидетельства выдающейся роли в его организации ряда блистательных руководителей форсированного строительства новых сибирских городов.

Важное место в понимания специфики проектирования и технологии югорского градостроения представляют воспоминания Ю.П. Баталина, А.Н. Отрадного, Ш.С. Донгоряна, В.Г. Чирского, Г.И. Шмаля. В них запечатлена вся социальная и психологическая панорама интенсивного городского строительства в экстремальной климатической ситуация севера Западной Сибири и не менее сложных парадоксальных мобилизационных условиях командно-административной системы экономики СССР (18).

Известная существенная субъективистская тенденциозность этого вида источников нейтрализовалась их перекрестной критикой статистическим материалом, содержащимся в ряде его сборников (19) и систематизированным 
нами в 20-ти таблицах, отражающих основные генерализирующие тенденции изучаемого градостроительного процесса на территории ХМАО-ЮГРЫ.

Не меньшую роль в этом процессе играла центральная и местная периодическая печать, издания которой автором изучены за весь хронологический период исследования. Наиболее информационно насыщенными из них явились газеты «Тюменская правда», «К победе коммунизма», «Сургутская трибуна», «Новый город», «Вестник», «ВестникСТС», «МК-Югра», «Экологическая газета», «Экологическое приложение к газете «Сургутская трибуна», региональный краеведческий журнал «Югра».

Вместе с тем в качестве гаранта защиты от известных имманентных односторонностей этого вида источников и максимальной реализации комплексного подхода к изучаемой теме и всестороннего изучения еe проблематики в качестве теоретической основы мы стремились привлечь мнения ученых, непосредственно причастных к академической градостроительной науке, архитекторов, проектировщиков, инженеров, которые участвовали в разработке планировочных и изыскательских проблем, вопросов нормативной базы строительства новых городов в агрессивных природно-климатических условиях севера Западной Сибири (20).

Основываясь на анализе научной литературы и источников, мы сочли целесообразным сосредоточить наше внимание на создании исторической реконструкции процесса градостроения в ХМАО-Югре в конце 1950-х - начале 1990-х гг. в силу его уникального опыта, накопленного в период эпохального промышленного и социального освоения крупнейшей нефтегазоносной провинции современной России.

\section{Примечания}

1. Ним Б.А. Партийное руководство развитием геологоразведочных работ на нефть и газ в Западной Сибири (1934-1966 гг.) // Коммунисты Западной Сибири (1917- 1967). Материалы научной конференции преподавателей общественных наук вузов Тюменской областной партийной организации. Тюмень, 1967; Он же. Периодизация и основные направления деятельности Тюменской областной партийной организации по развитию геологоразведочных работ на нефть и газ // На путях строительства коммунизма (Сб. статей к 50-летию Советской власти). Тюмень, 1968. 
2. Пашков Н.М. Деятельность партийных организаций Западной Сибири по созданию и развитию нефтегазового комплекса.1964-1980 гг. Томск: Изд-во ТомГУ, 1988.- 240 с.

3. Панарин C.M. Создание минеральной Западно-Сибирского нефтегазового комплекса (1961-1975 гг.): автореф. дисс... канд. ист. наук: 07.00.02. - Екатеринург, 1995.-23 С.; Он же. Открытие сибирской нефти. Сургут: Диорит, 2002. С.160-174.

4. Гаврилова Н.Ю. Градостроительная концепция освоения нефтедобывающих районов Западной Сибири и ее реализация (60-е-80-е гг.). // Ежегодник Тюменского краеведческого музея. Тюмень. 1999. С. 61-73.

5. Гаврилова Н.Ю. Социальное развитие нефтегазодобывающих районов Западной Сибири (1964-1985 гг.). Тюмень, 2002.

6. Гаврилова Н.Ю., Карпов В.П. Жилищно-гражданское строительство в районах нового промышленного освоения Севера Западной Сибири» (19651985 гг.). // Налоги. Инвестиции. Капитал. 2002. № 1-2. С. 238-244.

7. Карпов В.П., Гаврилова Н.Ю. Курс отечественной нефтяной и газовой промышленности. Тюмень, 2011. С. 212-222.

8. Колева Г.Ю., Колев Ж.М. Хозяйственное освоение Западной Сибири и ее заселение в разные исторические периоды. // Человек в нефтегазового освоения Севера. Материалы Всероссийской научной конференции. 17-18 ноября 2010 года. Тюмень, 2011. С. 110-114.

9. Колева Г.Ю. Строительство городов в районах нового промышленного освоения в 1960-1980-е гг. // Вестник Тюменского государственного университета. 2007. № 1. С.237-244.

10. Колева Г.Ю. Западно-Сибирский нефтегазовый комплекс: история становления. Часть 2. Тюмень, 2005.

11. Розанов Н.П. Крупнопанельное домостроение. М., 1983.

12. Стась И.Н. Первый генплан Сургута: история утверждения. // Всероссийская научная конференция «ХМАО-Югра: исторические вызовы и ответы», посвященная памяти известного краеведа, почетного гражданина Сургута И.П. Захарова. 6 декабря 2013 г. Сургут, 2013. С. 32-35; Он же. Центры урбанизации и расселения нефтяников - город Нижневартовск и Нижневартовский район. // Нижневартовский район в судьбах Югры. Материалы Всероссийской научно-практической конференции, посвященной 85-летию со дня образования Нижневартовского района. - Нижневартовск, 2013. - С. 35-43; Он же. Природно-географические ограничения и возможности 
градостроительного освоения и урбанизации ХМАО (1960-1980-е гг.). // Югра, Сибирь, Россия. Политические, экономические, социокультурные аспекты прошлого и настоящего. Материалы Всероссийской научной конференции, посвященной 20-летию высшего исторического образования в ХМАО - Югре. Нижневартовск, 24-25 октября 2013 г. - Нижневартовск, 2013.С. 208-215; Он же. Урбанизация самостроя: трущобы в нефтедобывающих районах советской Сибири (1960-1980-гг., 1966-1980-е гг.), 1917; Он же. Урбанизаация ХМАОЮгры в период нефтезазового освоения. Режим доступа на 6.05.2018. httpchelovekhayke.comurbahizasiya; Он же. Капитальное жилищное строительство в Х-Мансийском автономном округе в 1960-1980-е гг. // Сибирские строители: события и судьбы. Сборник статей Всероссийской научной конференции. Курган, 2017. Стась, Игорь Николаевич. Капитальное жилищное строительство в Ханты-Мансийском округе в 1960-1980-е гг. // Сибирские строители: события и судьбы: сборник статей Всероссийской научной конференции, г. Сургут, 25-26 ноября 2016 года. Сургут, 2016.

13. Стась И.Н. От поселков к городам и обратно: история градостроительной политики в Ханты-Мансийском округе (1960-е-нач.1990-х гг.). Сургут: Изд. дом «Дефис», 1916.-258 С.

14. Стась И.Н. Стать горожанином: урбанизация и население в нефтяном крае (1960-е - нач.1990-х гг.). Курган: ООО Курганский Дом печати, 2018. -168 с.

15. Колева Г.Ю., Стась И.Н., Шорохова И.И. Становление индустриально-урбанистического общества на территории Тюменской области. Тюмень, 2013.

16. Бирюков В. Годы и люди земли тюменской: книга в 3-х частях. Тюмень, 2000. Древний город на Оби: история Сургута. Екатеринбург, 1994; Захаров И.П. Моя земля. Сургут, 1999; История и перспективы градостроительного освоения территории Севера. Западно-Сибирский нефтегазовый комплекс. М., 2004; Кузнецов А.В. Мой Сургут. ХантыМансийск-Шадринск, 1996; История и перспективы градостроительного освоения территории Севера. Западно - Сибирский нефтегазовый комплекс. М.,2004; Соратники: поколение Виктора Муравленко. Тюмень, 2002; Чирсков В.Г. Уроки Щербины. М., 1999; Петрова Л.В., Показаньев Ф.Я. Сургут-Свердловск, 1987.

17. Юрасова М.К., Юрасова Г.М. Нефтяник. М., 1981.

18. Баталин Ю.П. Вместо предисловия. // История и перспективы градостроительного освоения территории Севера. Западно-Сибирский 
нефтегазовый комплекс. - М., 2004. С. 32-37; Он же. От игр «в кубики» к суперблокам: Годы, отданные тюменской нефти; Уйти от сезонности. // Соратники: поколение Виктора Муравленко. Тюмень, 2002. - С. 79-86; Бахилов В.В. Дорога к нефти. Свердловск, 1975; Мунарев П.А. Так было, так начиналось. (Записки председателя). Сургут, 2008; Из воспоминаний В.Г. Чирского. // История и перспективы градостроительного освоения территории Севера. Западно-Сибирский нефтегазовый комплекс. - М., 2004. С. 179-187; Донгарян Ш.С. Взгляды на градостроительство на Севере Западной Сибири. // История и перспективы градостроительного освоения территории Севера. Западно-Сибирский нефтегазовый комплекс. - М., 2004. - С 189-192; Он же. Нефть и Б.Е. Щербина; Нефть и В.Д. Шашин // Соратники: поколение Виктора Муравленко. Тюмень, 2002. С. 154-156; Из воспоминаний Бешкильцева В.А., главного архитектора Тюменской области в период становления ЗСНК. // История и перспективы градостроительного освоения территории Севера. Западно-Сибирский нефтегазовый комплекс. - М., 2004. С. 197-200; Шмаль Г.И. Юность комсомольская моя. Из воспоминаний Г.И. Шмаля. // История и перспективы градостроительного освоения территории Севера. Западно-Сибирский нефтегазовый комплекс. - М., 2004. С. 185-187; Он же. Юность комсомольская моя. Дела молодежные; На пути к рынку. // Соратники: поколение Виктора Муравленко. - Тюмень, 2002. С. 376384; Унжаков В.И. Я не делал карьеру, я просто работал. // Сургутские ведомости. 2003. 10 ноября.

19. Город Сургут в цифрах: Юбилейный статистический сборник. Сургут, 1995; Сургут: Экономика и финансы. Сургут, 2001.; Сургут: Культура, молодежная политика и спорт. Сургут, 2001; Сургут: Городское строительство и связь. Сургут, 2001; Обзор состояния окружающей среды города Сургута. 1993-2002. - Сургут, 2003; Экополис. Экологическое приложение к газете «Сургутская трибуна». 2000. январь. Вып. 1; Народное хозяйство Тюменской области за 1945-1980-е гг. / ЦСУ-РСФС. Статистическое управление Тюменской области. Тюмень, 1981; Народное хозяйство Тюменской области за два года девятой пятилетки. 1971-1973 гг.Статистический сборник. / ЦСУ РСФСР. Статистическое управление Тюменской области. Тюмень, 1973; Народное хозяйство Тюменской области в годы десятой пятилетки.1976-1980 гг. Статистический сборник. / ЦСУ-РСФСР. Статистическое управление Тюменской области. Тюмень, 1981; Тюменская область в цифрах за годы 
одиннадцатой пятилетки (1981-1985 гг.) / ЦСУ РСФСР. Статистическое управление Тюменской области. Тюмень, 1986.

20. Виноградов А.И. Концепция и проект планировки вторичной застройки жилого микрорайона № 8 в Сургуте (2001 г.) // Промышленное и гражданское строительство. 2002. №3; Вопросы реализации градостроительных предложений в Западной Сибири. Л., 1988; Лазарева И.В., Мельникова Т.Л. Этно-ландшафтный подход к расселению (на примере градостроительной истории Сибири). // Проблемы окружающей среды и природных ресурсов. 2001. № 11. С. 8-16; Лазарева И.В., Лазарев В.В. Город во времени и пространстве. Проблемы устойчивого развития. // Муниципальная власть. 1999. № 2. С. 14-17; Новые города в СССР. М., 1977; Лазарев В.В. Ретроспективная оценка историко-культурного развития Сургута и прилегающих территорий: Отчет по этапу НИР на тему «Выявление природо обусловленных направлений территориального развития г. Сургута Тюменской области. М., 1994; Лесков С.Н. Градостроительная политика при новых социально-экономических условиях. // Строительный вестник Тюменской области. 1999.№ 1; Лесков С.Н. Об архитектурно-строительной деятельности на территории муниципальных образований. // Материалы регионального совещания по местному самоуправлению. Тюмень, 1999; и др. 


\section{ГЛАВА 1. \\ ПРОЕКТНО-ИЗЫСКАТЕЛЬСКАЯ РАБОТА НА СЕВЕРЕ ТЮМЕНСКОЙ ОБЛАСТИ В 1960-Е ГГ.}

Огромную роль в градостроительном освоении севера Западной Сибири призвана была сыграть проектно-изыскательная деятельность, связанная с перспективами развития Ханты-Мансийского автономного округа - Югры как единого планировочного образования с комплексной инфраструктурой, объединяющей промышленное, социальное, инженерное и транспортное обеспечение с учетом взаимовлияния всех региональных и территориальных особенностей.

Открытие Шаимского, Мегионского и Усть-Балыкского месторождений нефти в 1960 и 1961 годах, казалось бы, являлось убедительным аргументом в пользу наличия в Западной Сибири крупной энергетической провинции углеводородного сырья, необходимости дальнейшего расширения геологоразведочных исследований, принятия инновационных решений, эволюции градостроительной политики и развертывания проектноизыскательных работ за Уралом, пересмотра традиционных стереотипов и поиска новых форм работы министерств и ведомств, проектных институтов и строительных организаций, архитекторов, экологов, социологов и инженеров, мобилизации духовного потенциала тружеников новой нефтегазоносной провинции.

19 мая 1962 года Совет Министров СССР принял специальное постановление, в котором правительство официально признало обнаружение в Западно-Сибирском регионе нефтяных и газовых месторождений значительной нефтегазоносности. Такая оценка не содержала корректировки предшествующей экономической политики развития топливно-энергетического комплекса СССР. Открытия нефтяных месторождений не рассматривались ещё как предвестник рождения новой Западно-Сибирской топливно-энергетической провинции, тем более доминирующей и безальтернативной. Промышленную добычу нефти предполагалось начать в 1966 году, а до этого времени министерствам и ведомствам фактически разрешалось осуществлять строительство рабочих поселений при крупных перспективных месторождениях (1).

Не в последнюю очередь принятие более решительной и масштабной стратегии освоения новых нефтяных месторождений было связано тогда с 
пересмотром, казалось бы, уже окончательно принятого правительственного решения о перспективах развития севера Западной Сибири, в основе которого лежала идея строительства крупнейшего в Европе гидроузла в районе Салехарда и затопления территории Западной Сибири.

Она возникла в начале 1950-х гг. в рамках долгосрочной программы гидротехнического освоения потенциала сибирских рек. Инициатором проекта выступил институт «Гидропроект», проектный институт Министерства строительства электростанций СССР. Он предусматривал строительство плотины протяженностью 130 км южнее Салехарда и затопление территории площадью 113 тыс. км². Мощность гидроэлектростанции, по замыслу проектировщиков, должна была составить 6-7 млн. кВт и с выработкой электроэнергии 32-35 млрд. кВт. В институте «Гидропроект» строительство Нижне-Обской ГЭС рассматривали как способ ликвидации дефицита электроэнергии в Средне-Уральском экономическом районе. В 1958 и 1960 годах проект гидроэлектростанции был обсужден на техническом совете Министерства электростанций СССР и признан экономически целесообразным.

Идею строительства Нижне-Обской ГЭС поддержали в Тюменском областном комитете КПСС. По мнению партийного руководства региона, эта ГЭС, находясь рядом с Уралом и Печорским бассейном, а оттуда близко к северным промышленным районам, сыграет огромную роль в их развитии и она необходима даже более, чем строящаяся Братская ГЭС на реке Ангара.

Однако в 1961 году новый первый секретарь Тюменского областного комитета КПСС Б.Е. Щербина отказался от лоббирования данного проекта, выбрав в качестве стратегического варианта развития области нефтегазовую промышленность. Против проекта Нижне-Обской ГЭС образовалась коалиция, состоявшая из ведомств нефтегазового комплекса, геологов, руководителей лесного и рыбного хозяйства, региональных органов власти, отраслевых и академических институтов, партийных, государственных и общественных средств массовой информации

В 1962 году решением Госплана СССР была создана Государственная экспертная комиссия (ГЭК) для проведения экспертной оценки техникоэкономической целесообразности строительства Нижне-Обской ГЭС.

Летом 1962 года ее авторитетные представители прибыли в Сургутское Приобье, чтобы на месте изучить проблемы развития народно-хозяйственного комплекса Западной Сибири в связи с намечающимся строительством НижнеОбской ГЭС. В январе и октябре 1963 года состоялось заседание 18 
Государственной экспертной комиссии. В результате жесткого противостояния Министерства энергетики и электрификации СССР, института «Гидропроект», с одной стороны, и коалиции противников проекта, с другой стороны, Госплан СССР, опираясь на оценку ГЭК, принял решение отложить вопрос о строительстве ГЭС (2).

Однако споры вокруг её строительства велись еще в течение нескольких лет. То затихая, то вспыхивая вновь, они прекратились только в 1966 году, когда в зонах предполагаемого затопления было открыто более двадцати месторождений нефти.

Эта неопределенная позиция Совета Министров СССР особенно отчетливо прослеживается в его Постановлении от 4 декабря 1963 года № 1208 «Об организации подготовительных работ по производственному освоению открытых нефтяных и газовых месторождений и о дальнейшем развитии геологоразведочных работ в Тюменской области», где, с одной стороны, с удовлетворением отмечалось, что «за последние годы в результате проведенных геолого-разведочных работ в Тюменской области открыто 18 газовых и 9 нефтяных месторождений, которые подтвердили богатую нефтегазоносность Западно-Сибирской низменности и возможность создания в этом районе крупнейшей нефтегазодобывающей базы страны» (3).

С другой же стороны, о перспективах градостроительства в Среднем Приобье в Постановлении говорилось весьма лаконично. Упоминание о нем сводилось к разрешению Совета Министров осуществлять «проектирование и строительство городов и крупных промышленных предприятий, связанных с перспективным развитием нефтяной и газовой промышленности в районе среднего течения реки Оби». При этом и такая общая констатация по существу блокировалась содержащимся в Постановлении предупреждением о том, что их требуется «осуществлять при уровне расположения строительных площадок с отметкой не ниже 30 метров, до которой может подняться уровень реки Оби при возможном подпоре его плотиной Нижне-Обской ГЭС» (4).

Следует добавить, что в это время не последовало и ожидавшегося перераспределения средств на развитие Среднего Приобья. В борьбе за финансовые потоки столкнулись тогда интересы ведомственных и региональных группировок бюрократии Средне-Уральского совнархоза и правительства Казахстана, добивавшихся канализации «нефтяных» рублей в металлургическую промышленность, а также совнархозовских деятелей ВолгоУральского района, боровшихся за ассигнования новых прогнозируемых 
месторождений, и влиятельных руководителей союзных республик, организовавших поиск «своей» нефти на заведомо бесперспективных месторождениях Закавказья и Прибалтики (5).

Таким образом, несмотря на открытие в начале 1960-х гг. крупнейших в стране нефтяных месторождений и начавшуюся активную разработку планов градостроительного освоения новой нефтегазовой территории, интенсивной системообразующей проектно-изыскательной деятельности мы не наблюдаем. Градостроительная перспектива севера Западной Сибири оставалась дискуссионной как в научных кругах, так и во властных структурах.

Гораздо активнее и оптимистичнее по понятным причинам на перспективу развития нефтегазового производства в Ханты-Мансийском национальном округе реагировал Тюменский областной комитет КПСС во главе с Б.Е. Щербиной. Ссылаясь на воспоминания В.Г. Чирского, министра «Миннефтестроя» в 1980-е гг, тюменский историк М.В. Комгорт обращает внимание на то, что в отсутствии принимаемых правительственных решений в декабре 1961 года первый секретарь Тюменского обкома партии Борис Евдокимович Щербина представил докладную записку в адрес ЦК КПСС. В ней он не только уверенно констатировал открытие в Тюменской области нефтегазоносной провинции с большими потенциальными запасами нефти и газа, но и решительно настаивал на значительном увеличении объёмов геологоразведочных работ для организации в ближайшие годы нефтедобывающей и газовой промышленности (6).

Столь активная позиция Тюменского обкома партии и его конкретные предложения подтверждались последовавшей серией новых нефтегазовых открытий. К 1964 году в Западной Сибири уже четко вырисовывались три крупных нефтегазовых провинции: Шаимо-Березовская, Северная и Сургутская. К этому времени из 20 газовых и 10 нефтяных открытых в Тюменской области 5 находились непосредственно в Сургутском районе: Усть-Былыкское, Западно-Сургутское, Северо-Сургтское, Локосовское и Южно-Балыкское (7).

Однако правительственных решений о формах расселения прибывавшего населения не поступало. При этом вряд ли можно согласиться с утверждением некоторых авторов о том, что «с 1960 года ежегодно Тюменской области выделялись бюджетные ассигнования на разработку проектов планировки промышленных объектов и узлов, топографических и геологических изысканий и разработку генеральных планов городов, поселков, проектов детальной 
планировки центров и районов первоочередной застройки городов, районных сельскохозяйственных планировок и генпланов сельских населенных мест. Эти работы соответственно включались в планы градостроительных институтов» (8).

Об этом свидетельствует содержание «Памятной записки» первого секретаря Сургутского районного комитета КПСС В.В. Бахилова, адресованной 15 января 1964 года Тюменскому областному комитету партии, в которой автор, формулируя вывод, вытекающий из реальной потребности массового расселения прибывающих в Сургутский регион и необходимости начала масштабного жилищного строительства, с горечью констатировал, что «до сих пор никто не приступал к проектированию базового города», и просил членов бюро Тюменского обкома партии «ускорить отвод и проектирование площадки под строительство поселков и города». Партийное руководство области поддержало эту инициативу и выступило главным заказчиком такой документации (9).

Трудности решения проблемы расселения прибывающих трудовых ресурсов усугублялись тем, что в начальный период освоения Среднего Приобья в стране не было стандартных норм и правил гражданского и жилищного строительства на этой уникальной новой территории с такими масштабами и столь сложными специфическими природно-климатических условиями.

В основе этих исследований использовался богатый научный материал, созданный первооткрывателями северной градостроительной тематики, такими как В.В. Муравьев, Г.В. Римский-Корсаков, Г.В. Платонов, В.Г. Танганян и другие (10).

Территория Тюменской области делилась ими на четыре природных региона, различающихся по хозяйственной специализации и природным условиям, соответственно на Южный рекреационный (группа административных районов южной части области), Ближний Север (ХантыМансийский автономный округ), Дальний Север (Ямало-Ненецкий автономный округ до Северного полярного круга) и Арктический Север (11).

Различия этих зон определяли особенности теплотехнических характеристик, конструктивные особенности строительства фундаментов, отличия санитарных и пожарных норм. Но они не позволяли отступать от установленных для средней полосы страны нормативов распределения площадей жилых и общественных помещений в квадратных метрах в расчете на одного человека, высоте этажей жилого помещения, размеров окон, дверей и других деталей типовых конструкций, числе детей для детских учреждений. 
Однако условия проживания и работы в различных регионах севера не только отличались от условий средней полосы, но и имели существенные различия на самих территориях Ближнего и Дальнего Севера.

Это усложняло работу проектировщиков. Накопленные Академией Архитектуры СССР до открытия нефтегазовых месторождений в Среднем Приобье проектно-изыскательные разработки оказывали неоценимую помощь в строительстве городов на Дальнем и Крайнем Севере. Так, например, еще в 1947 году при строительстве трёхэтажной школы инженером Г.Чернаковым в Якутске был применен метод сцепления боковых поверхностей свай с вечномерзлыми грунтами. Этот принцип впоследствии стал ведущим в практике мирового северного градостроения.

В начале 1960-х гг. осуществлялась активная застройка четырёхэтажными и пятиэтажными домами Магадана, Якутска и Салехарда. Эффективная идея замкнутых дворовых пространств, обтекаемых ветровыми потоками, широко применялась и в ходе строительства Ноябрьска, Нового Уренгоя, Надыма. Здесь внедрялись и иные плодотворные архитектурно-строительные проекты для дальнейшего арктического освоения тюменского Заполярья (12).

Но парадокс заключался в том, что они могли быть использованы в условиях жары и вечной мерзлоты. Лишь в Сургуте мы встречаем реализацию идеи замкнутых дворов, потому что, судя по высказываниям его главного архитектора В.И. Унжакова, «территория застройки Сургута не являлась «самой неблагоприятной... здесь болота были не трясинные, а верховые» (13). А для проектирования и строительства на трясинных болотах Среднего Приобья при очень низких температурах и высокой влажности таких норм и правил не было ни в СССР, ни за его пределами. Как вспоминал Ш.С. Донгорян, в то время заместитель министра нефтяной промышленности СССР, «...весь 1966 год ушел впустую на поиск возможности привлечь чьи-то силы и приступить к разработке требуемых норм и правил (14).

Необходимо было значительно активизировать работу ранее существовавших проектно-архитектурных институтов и создать новые, сосредоточив их внимание на инженерно-геологических изысканиях и подготовке принципиально новых детальных планировок застройки селитебных зон территории городов Среднего Приобья на конкретных примерах открытых районов промышленного освоения.

В 1963г оду был организован институт ЛенНИИПградостроительства. Он был создан на базе Горстройпроекта и Академии архитектуры. А чуть позднее 
был основан институт, ориентированный на работы по Северу - ЛенЗНИИЭП (15).

Ведущие ученые института ЛенНИИПградостроительства В.К. Свешников, С.И. Крестьяшин, Ю.Б. Хромов, В.Н. Маслякова, Т.Н. Чисткова, Т.И. Раскошная, Л.К. Панова, К.И. Морозова и ряд других внесли заметный вклад в изучение проблем градостроения в этом регионе. В стенах ЛенНИИПградостроительства под научным руководством членов Союза Архитекторов России, кандидата экономических наук Э.А. Зеленина и кандидата архитектуры К.И. Морозовой, была обоснована концепция расселения в регионе Западно-Сибирского нефтегазового комплекса с учетом системного подхода при вахтово-экспедиционном методе. Ими была разработана типология поселений в различных районах комплекса и выполнены модели базового города, постоянного и мобильного поселков.

В стенах этого института учеными осуществлялась большая работа и по теоретическому обоснованию основных направлений развития градостроительства на Ближнем Севере. Особенно заметное влияние на проектирование Нефтеюганска оказал рано ушедший из жизни архитектор В.В. Кадников, который непосредственно работал и очень много сделал для решения проблем размещения этого города. Будучи талантливым архитектором с тонким художественным вкусом, глубоким градостроительным чутьем, он оказывал и практическую помощь в оформлении архитектурных фасадов города Нефтеюганска (16).

Нефтеюганская бригада была крупнейшей в институте. Наибольший вклад в ее работу внесли архитекторы С.А. Ковалев, Е.В. Рудова, И.М. Типикин, Т.И. Литвиенко, Е.В. Судакова, И.Н. Новак, Т.Э. Прасолова, Е.В. Луконина, И.И. Попова, а так же конструкторы Е.В. Рукавцова, В.А. Комиссаров, А.А. Дрогичинский, Н.Н. Фелькнер, М.Ф. Гутан, Е.В. Видунова, обеспечившие проектную устойчивость сооружений.

С истинным энтузиазмом и самоотдачей добивались совершенствования технического качества проектов инженеры А.Г. Петров, Б.Н. Богданов, Г.Е. Нехамкис, С.Л. Бохман, Н.А. Масленнкикова, И.Н. Максимова (17).

С середины 1960-х гг. вопросами расселения и формирования новых городов на севере Тюменской области стали активно заниматься архитекторы Ленгипрогора Госстроя РФ М.С. Колосовский, Е.С. Квашнина-Самарина, А.И. Рысс, А.Г. Варзар, В.В.Прокопьева, сыгравшие решающую роль в составлении генеральных планов и проектов детальной планировки Сургута, Тюмени, Тобольска, Ялуторовска, Заводоуковска (18). 
Переход на комплексное проектирование производственной инфраструктуры в увязке с градостроительным освоением территории связан с подключением к работе Проектного института № 2 Госстроя СССР. Позднее, по мере развития потенциала Тюменской области в качестве территориальной организации, формирующей промузлы, стал выступать Тюменский Промстройпроект (19).

В середине 1960-х гг. коллектив проектировщиков сложился и в ходе строительства Нижневартовска. Он целенаправленно добивался создания полноценной человеческой среды обитания в северных условиях центра Западной Сибири. Должность главного архитектора Нижневартовского района было введена ещё в 1964 году (20). История сохранила имена людей, которые в различные годы руководили архитектурой градостроительства в Нижневартовске. Любопытно, что первым архитектором этого города была очаровательная женщина Г.А. Поткина, с которой нижневартовцы в шутку ассоциировали привлекательный образ своего города. В разное время управление архитектуры и градостроительства возглавляли В.В. Никифоров, В.В. Бахчеев и В.В. Антонов. С 1987 года длительное время начальником Управления являлся В.М. Добрыгин, член Союза архитекторов Российской Федерации. За многолетний добросовестный труд ему были присвоены звания «Заслуженный архитектор Ханты-Мансийского автономного округа» и «Почетный архитектор Российской Федерации (21).

В новый период своего развития вступало тогда и Областное управление архитектуры. В это время Тюменское областное Управление архитектуры напоминало штаб Всесоюзной стройки, куда стекалась вся информация, координировались все вопросы проведения инженерных изысканий, проектирования и строительства новых городов, поселков, их инженерного обеспечения и много других вопросов. Как вспоминал начальник отдела строительства и архитектуры Тюменского облисполкома А.Н. Отрадный, только в 1985-1987 гг. было проведено 47 областных градостроительных советов, 23 технических совещания, на которых рассматривались генеральные планы и проекты детальных планировок городских поселений (22).

Строительство новых городов в ХМАО-Югре начиналось с выбора площадки для их дислокации. Выбор будущего «месторазвития» нефтяного города определялся возможностью планового размещения на нем первоочередных объектов производства, жилья, дорог, инженерных сетей, очистных сооружений, необходимостью сохранения при этом для будущей капитальной застройки наиболее благоприятных и выразительных территорий, 
зеленых массивов, наличие возможности осуществления первоочередного и перспективного зонирования с определением промышленных, селитебных, коммунальных и иных территорий с тем, чтобы в дальнейшем при разработке генеральных планов эти отводы можно было органически включать в них.

Но площадок, пригодных для крупномасштабного строительства на территории Югры, практически не было. По инженерно-строительным стандартам все они относились к категории ограниченно пригодных или непригодных по условиям заболоченности, заторфованности, вечной или вековой мерзлоты, наличию оползней по длине берегов и других неблагоприятных физико-географических явлений (23).

Сургут, Нефтеюганск, Нижневартовск, Урай неслучайно стали центрами проектируемых буровых работ на профилях Средней Оби. Главным аргументом выбора Государственной комиссией базовых площадок для нефтеразведки являлось расположение их на водной магистрали. Только реки могли обеспечить доставку необходимых грузов и механизмов. Территории, расположенные по берегам рек, имели более благоприятные природные условия для их разгрузки, размещения и транспортировки. Поэтому все новые поселения Тюменской области располагались на магистральных водных путях. Выбранные площадки будущих городов Сургута, Урая, Нефтеюганска, Нижневартовска и других характеризовались спокойным рельефом, слабой залесённостью и некоторой заболоченностью. Эти факторы характерны для любой пригодной для строительства площадки в этом регионе.

Так, например, застройка города Нефтеюганска началась с редкого удобного для подъезда и обеспеченности питьевой водой берега, относительно свободного от топляка и валежника. Первопроходцы юганской нефти называли эту просеку улицей Ю. Гагарина. Такое название сохранилось до эпохи интенсивной городской застройки Нефтеюганска. Имя Ю. Гагарина носит сегодня одна из центральных улиц города и восходит ко временам догородского строительства, когда так, ассоциируя с космической устремленностью своего времени, назвали удобную прибрежную полоску земли юганские первооткрыватели нефти. Любопытно, что первоначально поселок назывался «Партсъездовский», но впоследствии он был переименован в Нефтеюганск, символизировав два характерных компонента его северной урбанизационной самоидентификации: «черное золото» Сибири и Юганскую Обь (24).

На месте строительства Нижневартовска, там, где впадает в Обь река Вах, с 1909 года стояла построенная деревянная пристань. Через три года на берегу, 
возле нее, возвели пять добротно срубленных деревянных домов, в которых проживало 11 человек. В январе 1924 года здесь был образован Нижневартовский сельский совет, а 29 сентября 1964 года селу был присвоен административный статус рабочего поселка, насчитывающего 1,5 тыс. жителей. Он стал, несмотря на большую заболоченность района, надежным плацдармом для создания города Нижневартовска (25).

Для выбранной площадки города характерна была проблема разрушения берега Оби. В 1960-х гг., когда только начиналось обустройство города, за год в зоне излучины Оби берег смывало порой до 50 метров. Еще тогда возникали идеи отвода основного русла реки в протоку, куда устремлялись воды во время паводка, с тем чтобы избежать интенсивного разрушения берегов. Впоследствии были возведены береговые укрепления и построена набережная на правом берегу Оби, ставшая любимым местом отдыха горожан (26).

Создавая генеральный план г. Нижне-Вартовска, находящегося на территории Ближнего Севера, архитекторы СибЗНИИЭПа, выполнявшие основные работы детальной застройки города, предпочли принцип регулярной планировки, основанный на сибирской традиции XIX века. Суть линейного принципа застройки состоял в том, что вдоль основной речной транспортной магистрали параллельно укладывалась автомобильная дорога, связывающая набережную с железнодорожным вокзалом. Общая вытянутость центра города вдоль реки еще более подчеркивала характер линейной структуры генерального плана (27).

Город прошел все этапы пионерного освоения: от поселка нефтяников и строителей из одноэтажных и двухэтажных домов на первом этапе с последующим возведением московскими строителями шестнадцатиэтажных жилых зданий, украсивших город, нетипичных для Ближнего Севера. Расположенный на плоском рельефе Нижневартовск приобрел черты продуманного композиционно-пространственного решения ритмическим повторением шестнадцатиэтажных конструкций на набережной. Они придали силуэтный характер застройке города при взгляде на него с реки. Сильное впечатление на жителей и гостей города оказывало повторяющееся чередование жилых групп с защищенными от ветра пространствами украшенных «зон затишья», вкраплениями лесных массивов прибрежного парка.

Хотя такой принцип застройки в условиях северной зоны не являлся типичным и идеальным, необходимо отметить, что первый генеральный план, разработанный ГИПРОГОРОМ в 1970 году, рассчитанный на 150 тыс. жителей 
и откорректированный в 1976 году с прогнозом населения к 2000 году на 280 тыс., полностью оправдался, подтвердив высокую компетентность ведущего сибирского проектного института (28). Большую роль в проектировании города сыграл А.Н. Отраднов, прошедший трудовой путь от рядового архитектора до главного архитектора Тюменской области и главного архитектора института «Тюменьгражданпроект» (29).

Основание города Урая своими истоками восходит к 1947 году, когда в Шаимском районе начались поиски нефти и газа. В 1958 году геологи вышли к Конде. Они выявили Мулымьинскую и Трехозерную структуры и определили места установки скважин. Хорошие результаты бурения доказали перспективность Шаимского района. В 1960 году приказом по Тюменскому геологоразведочному управлению была организована полевая Шаимская геологоразведочная экспедиция с расположением в селе Чантырья. Но это была окраина нефтяного района. Поэтому в июле 1960 года началась перебазировка дислокации экспедиции в поселок Урай, в то время представлявший из себя лесозаготовительный участок Кондинского леспромхоза. «Ураями» ханты и манси называли многочисленные ровки, вытянутые ямы и некоторые протоки, десятками встречающиеся на каждом километре в пойме реки. Это название закрепилось за рабочим поселком, который 25 июня 1965 года вместе с Сургутом был преобразован в город окружного подчинения (30).

В этой связи особо хотелось бы сказать о Сургуте. Село Сургут имело ряд несомненных преимуществ перед другими предполагаемыми местами высадки геологоразведчиков экспедиции Ф.К. Салманова. В то время Сургут являлся самым крупным населенным пунктом выбранной территории разбуривания. Он был районным центром. Все другие населенные пункты, включавшие в себя деревни Юган, Угут, Ачамовы-2, Тюмкины, Каймысовы, Белый Яр, Пилюгино, Сайгатино, Тундрино, располагались на значительном расстоянии друг от друга и насчитывали от 3 до 5 дворов. Часть из них размещалась на реке Малый Юган, которая являлась судоходной только в период высокого стояния вод на протяжении 450 км от устья до деревни Каймысовы. Коэффициент извилистости этой реки был достаточно высок, а её верховья сильно засорены валежником, карчами и топляком, на ней имелись перекаты, особенно многочисленные в верховьях. Все это сильно затрудняло, а местами делало невозможным судоходство и передвижение плавучих буровых установок на малых реках. Кроме того, возможность поставки ГСМ и продуктов питания с баз Ханты-Мансийска и Колпашева, расположенных по сибирским меркам на сравнительно небольшом расстоянии от Сургута, еще более усиливали 
административный потенциал будущей метрополии сибирской нефтегазовой провинции.

В 1957 году, к моменту высадки нефтеразведочной экспедиции Ф.К. Салманова, Сургут представлял собой два отдельных населенных пункта, собственно Сургут и расположенный в двух километрах от него поселок Черный Мыс с общим населением примерно пять тысяч человек и существованием традиционной для севера необходимой элементарной инфраструктуры. В самом Сургуте проживало, по разным данным, около трех тысяч человек. Это были преимущественно рабочие рыбоконсервного завода и члены колхоза «Путь Ленина» со своими семьями. Здесь имелись пристань, госпароходство, аэродром, гидропорт, моторнорыболовецкая станция, рыболовецкий кооператив, начальная, семилетняя и средняя школы, маслозавод, детские ясли, медпункт, дом культуры, две столовые, пекарня, магазины, районный банк и почта (31).

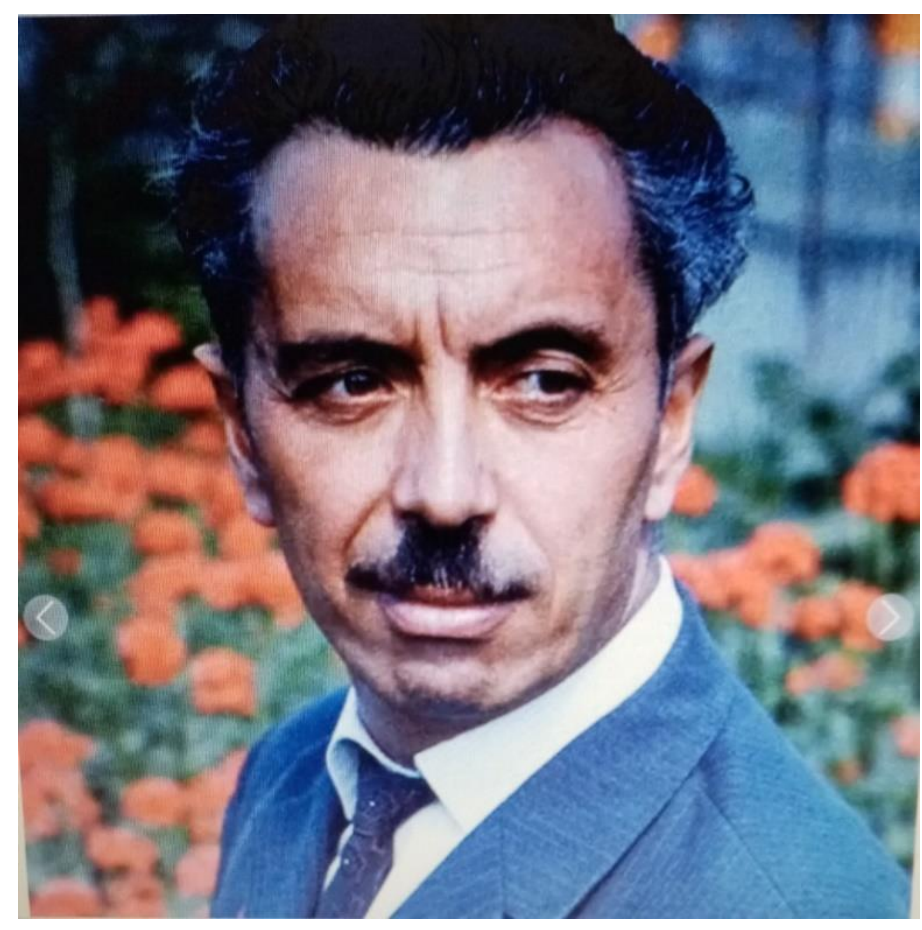

Фарман Курбанович Салманов,

начальник нефтегазоразведочных экспедиций в Сургуте (1957-1962),

Усть-Балыке (1962-1964), Горноправдинске (1964-1970),

главный геолог (1970-1978),

начальник Главтюменьгеологии (1978-1987),

первый заместитель министра геологии СССР (1987-1990),

Герой Социалистического Труда 
По мнению авторитетного исследователя А.И. Тимошенко, ключевым центром формирующейся урбанизационной системы поселений Сургут выступил в силу того, что аккумулировал значительную часть градообразующих факторов региона, способствовавших стихийному росту и расширению города (32).

Вызывает интерес точка зрения основателя объединения «Тюменнефтегаза» В.И. Муравленко, который одним из первых пророчески определил роль и место Сургута как центра освоения Западно-Сибирской нефтегазовой провинции. Он убежденно заявлял: «Сургут - отличнейший плацдарм. Сюда мы перебазируем объединение «Тюменнефтегаз», Трест буровых работ, поближе к производству, к нефтепромыслам. Кстати, тут же обоснуется и дирекция строительства нефтепромысла Усть-Балык-Омск. Здесь же намечается строительство мощной электростанции. Она будет работать на попутном газе. Первая такая в нашей стране» (33).

Изучение воспоминаний о многосторонней деятельности В.И. Муравленко свидетельствует о его большом профессиональном интересе и глубоком знании истории Сургута. Из них становится известно, что помощница В.И. Муравленко Галина Ивановна Запорожец обнаружила в фондах библиотеки Тюменского музея целую серию редких старинных книг в «мраморных корочках» и представила их начальнику нового главка. По ночам, урывая время от сна, Виктор Иванович читал эти уникальные книги. Не просто восторженно, а со знанием дела он заявлял за два года до празднования 375-летия г. Сургута: «Представляю: три и три четверти века! Возраст. Фактор истории. Есть необходимость учесть нам, зачинателям нового нефтяного периода в жизни Сургута. Нам очень надо знать минувший день края...» (34). 


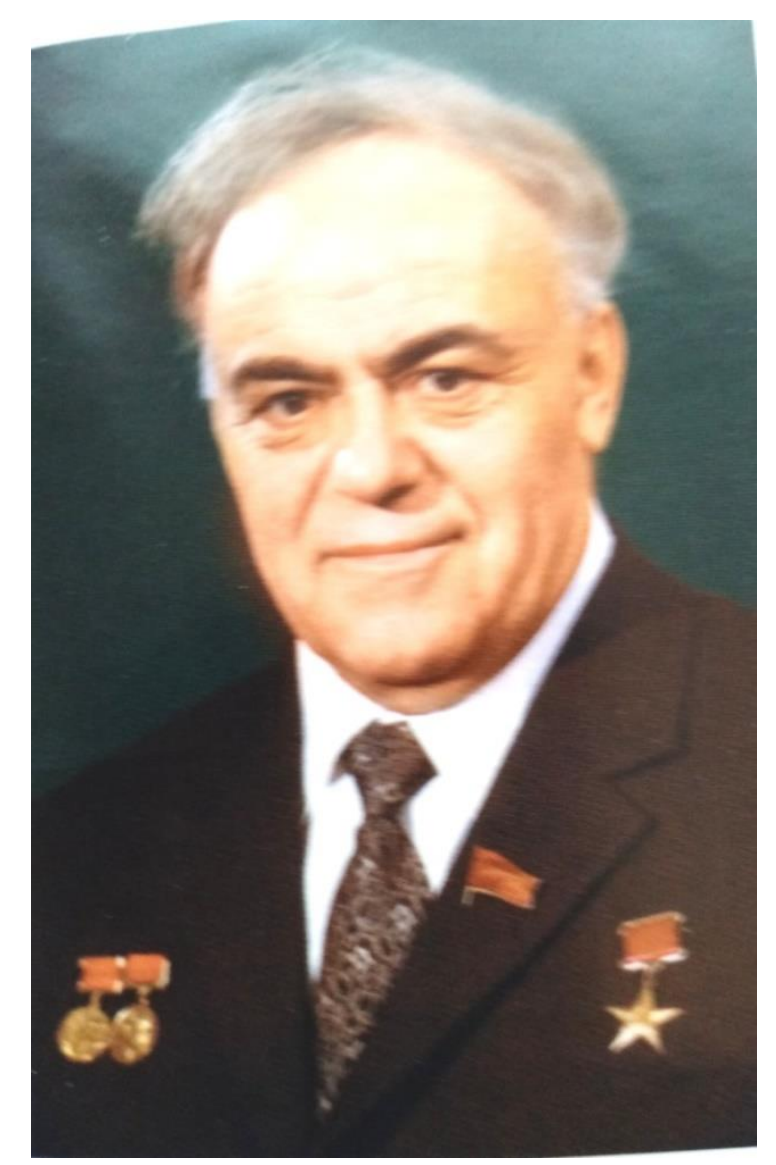

Виктор Иванович Муравленко, организатор нефтяной и газовой промышленности,

руководитель предприятия «Главтюменнефтегаз» в 1965-1977 годах, Герой Социалистического Труда, лауреат Ленинской и Государственной премий

O масштабах социально-экономического значения, которое придавал Сургуту В.И. Муравленко, свидетельствуют его планы создания города «кузницы кадров». Он писал: «Учебно-курсовой комбинат в Сургуте есть. Создадим еще профтехучилище, нефтяной техникум. В Тюмени в прошлом году открылся индустриальный институт. А в Сургуте мы организуем его филиал с дневным и вечерним отделениями...» (31). Рассуждая о размещении высших учебных заведений в Сургуте, В.И. Муравленко очень резко высказывался по поводу заявлений Лавренева, попечителя Западно-Сибирского учебного округа, который в свое время утверждал, что «открытие Томского университета было ошибкой». «Может быть, жителям Сургута тоже полагается иметь университет? Так что же, нужно открывать университет и в этом месте?» 
- задавал наследник Фамусова казавшийся ему риторическим вопрос» (36). - А почему бы и нет! - с оптимизмом возражал своему незримому оппоненту Виктор Иванович. - Придёт пора - будет университет и в городе Сургуте» (37).

Следует заметить, что такая авторитетная позиция первого лица нефтяной промышленности края имела большое значение не только для критики архаичного мнения попечителя учебных заведений начала XX века, но и для преодоления консервативной инерции части чиновников и обывателей Сургута, выступавших против создания в нем университета уже в конце XX века. «Сургут станет стольным градом нефтяного Приобья!» - таковым был главный лейтмотив всех выступлений В.И. Муравленко по вопросам перспектив его дальнейшего развития в первой половине 1960-х гг.

В то же время, по воспоминаниям старожилов, «наш Сургут был еще совсем маленьким, сплошь деревянным и занимал своими избами и дворами пространство полуострова от Саймы до современной улицы ЭнгельсаУниверситетской». При этом сургутяне делили свое небольшое поселение на две почти равные части, на «верх» и «низ». Все, кто жил на восток от центральной улицы Народной, назывались «верховские», на запад «низовские». Если бы такое деление сохранилось до наших дней, то горвоенкомат и Дом памяти и согласия оказались бы «верховскими», а здания администрации и газеты «Новый город» - «низовскими» (38). Тогда сургутские стороны и направления определялись по течению реки Оби.

В 1964 году работавшая в Приобье Государственная комиссия под председательством академика М.А. Лаврентьева, в силу исторического каприза почти однофамильца упомянутого чиновника из XIX века Лавренева, в качестве опорной базы по эксплуатации нефтяных месторождений и дальнейшего освоения Крайнего Севера назвала Сургут (39).

Проектировка новых городов уже велась. В июне 1964 года Тюменский обком КПСС и Облисполком депутатов трудящихся приняли совместное постановление «О схемах планировки городов Урая, Нижневартовска и Нефтеюганска» (40). 19 октября 1964 года облисполком утвердил проект генеральных планов развития этих городов, разработанных Башкирским государственным институтом по проектированию предприятий и сооружений нефтедобывающей промышленности (Башнефтепроект). В чрезвычайно сжатые сроки, за три месяца, при полном отсутствии топографических материалов и обслуживания геологических исследований институтом было разработано 3 генеральных плана. Они определяли расчетную численность населения Урая в 


\section{ГОРОДСКОЕ СТРОИТЕЛЬСТВО В ХАНТЫ-МАНСИЙСКОМ АВТОНОМНОМ ОКРУГЕ - ЮГРЕ (к.1950-х - сер.1990-х г2.)}

33 тыс. человек, Нижневартовска - в 44 тысяч человек, а Нефтеюганска - в 18 тысяч человек (41).

О масштабах населения нового города в Сургуте велись бурные дискуссии. В ходе полемики предпринимались попытки обосновать оптимальное количество его населения. Расхождения были очень большими и колебались от 200 до 700 тысяч человек. Инженер Реутский из «Сибгипротранса», например, еще в 1962 году прислал в Сургутский райком КПСС письмо, где настоятельно предлагал ставить вопрос о создании самостоятельной Сургутской области. И это при наличии только 50000 населения по всей Средней Оби (42).

Трудности генерального проектирования Сургута состояли в том, что в начале 1960-х гг., когда возникла его необходимость для расселения значительного числа нефтяников и обслуживающего персонала городов и поселков, окончательные границы нефтегазоносности в Среднем Приобье не были очерчены. Разница в прогнозах специалистов относительно перспектив добычи нефти и газа в Среднем Приобье была колоссальной. Одни цифры от других отличались в 30 раз (43).

Весьма примечателен в связи с этим один исторический факт. Судя по воспоминаниям первого секретаря Сургутского горкома КПСС М.М. Конева, мнение начальника «Главтюменнефтегаза» В.И. Муравленко начало меняться после того, как во второй половине 1960-х гг. «заговорил» уникальный Самотлор, а Сургут остановился в своем развитии на эксплуатации открытого еще в ноябре 1961 года Западно-Сургутского месторождения нефти и Солкинской площади.

В 1970-1974-е гг. лидерство по количеству жителей в ХМАО принадлежало Сургуту. В 1975-1980 гг. пальма первенства по числу жителей перешла к Нижневартовску: 122,2 тыс. против 120,8 тыс. в 1980 году (44). М.М. Конев вспоминал: «Мне очень памятен тяжелейший разговор, который состоялся в начале 1971 года с Борисом Евдокимовичем Щербиной - первым секретарем обкома партии и Виктором Ивановичем Муравленко - начальником «Главтюменнефтегаза». Мы ехали в одной машине в аэропорт... И вдруг фраза Муравленко: «И все-таки, Борис Евдокимович, Сургут не будет центром Среднего Приобья. Все надо перемещать в Нижневартовск: центр добычи нефти, вторую ГРЭС, железную дорогу. Наш главк намерен, и мы это уже делаем, резко сократить капитальные вложения в Сургут» (45). 
У М.М. Конева был такой опечаленный вид, что Б.Е. Щербина сказал: «Михаил Михайлович, Виктор Иванович неточно выразился. Я убежден в большом значении Сургута и в его большом будущем. Главное для партийной организации - широкий размах геологического поиска на перспективных площадках, скорое открытие нескольких нефтяных месторождений вблизи Сургута и их быстрый ввод. Форсировать ввод энергоблоков на Сургутской ГРЭС и от нее строить по Северу линии электропередач. Сургут будет городом с 300-тысячным населением» (46).

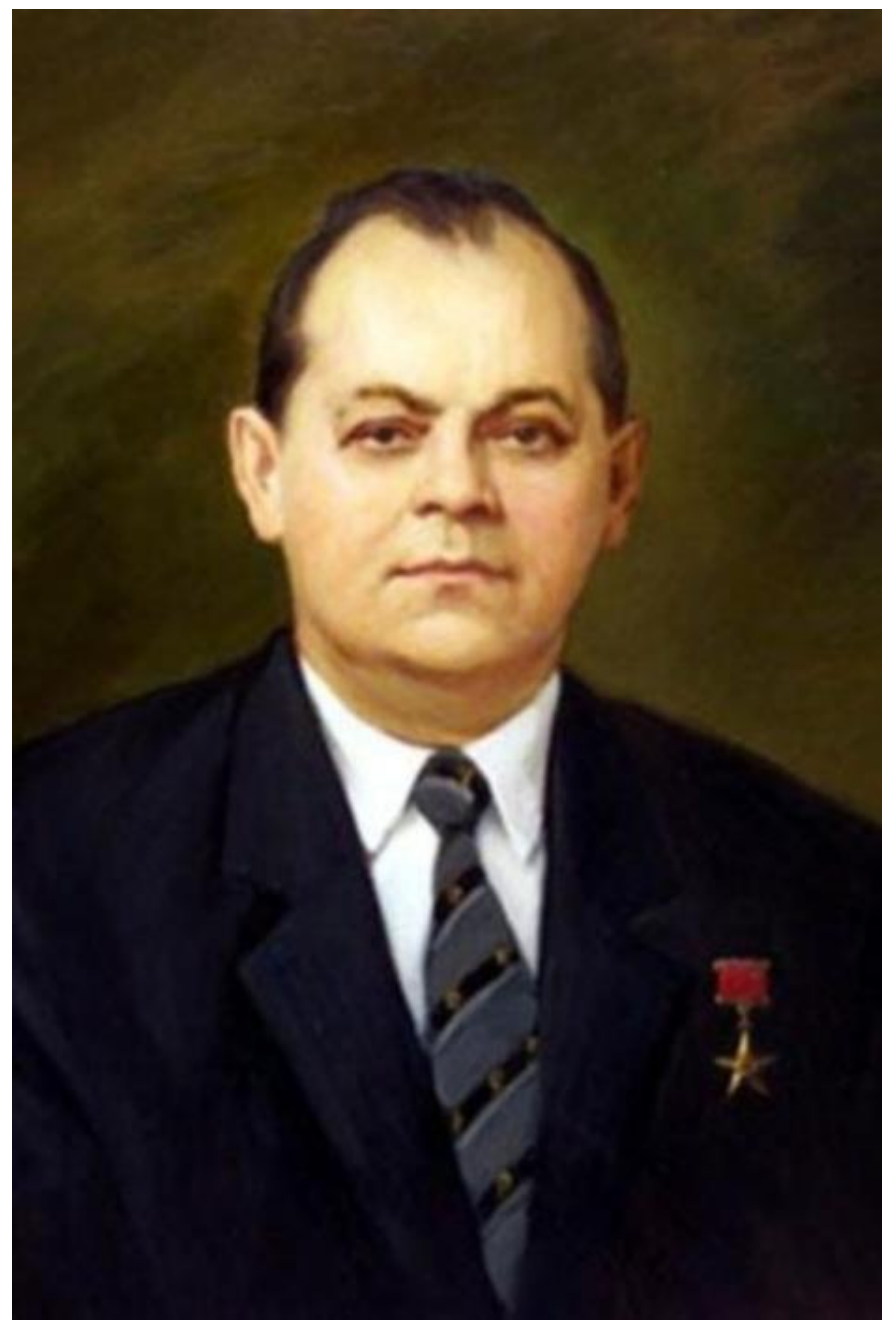

Борис Евдокимович Щербина,

Герой Социалистического Труда, первый секретарь Тюменского обкома КПСС (1961-1973), министр строительства предприятий нефтяной и газовой промышленности (1973-1984), заместитель Председателя Совета министров СССР (1984-1989) 


\section{ГОРОДСКОЕ СТРОИТЕЛЬСТВО В ХАНТЫ-МАНСИЙСКОМ АВТОНОМНОМ ОКРУГЕ - ЮГРЕ (к.1950-х - сер.1990-х г2.)}

По мнению М.М. Конева, этот разговор с Борисом Евдокимовичем еще сильнее укрепил партийных и хозяйственных руководителей в их «приверженности «генеральной линии» строительства нового города в Сургуте» (47).

Пророческим словам Б.Е. Щербины суждено было сбыться. Нефтедобыча стала и остается основой градостроения в Сургуте до сегодняшнего дня. В течение исследуемого периода Сургутский нефтяной регион, если не брать во внимание Самотлор, стал самым перспективным. Чисто «сургутские» месторождения Федоровское, Западно-Сургутское, Солкинское, Быстринское, мощные кусты Ноябрьска и Лангепаса составили уникальный по значимости нефтедобывающий регион.

На протяжении второй половины XX века Сургут не только не терял свою авангардную роль в добыче углеводородного сырья в России, но и усиливал ее. Обусловлено это было соотношением запасов нефти к уровню ее добычи. Так называемый «показатель кратности» в «Сургутнефтегазе» всегда оставался очень высоким.

Кроме того, здесь имелись большие запасы попутного и природного газа. Если в целом по стране в конце нашего исследуемого периода добывалось около 26 млрд. кубометров, то 9 из них были сургутские. Тем самым обеспечивалась топливом самая мощная в Европе электроэнергетическая база Сургутская ГРЭС. Крупный транспортный узел авиационного, железнодорожного, автомобильного и речного сообщений компенсировал издержки градостроения, связанные с географической удаленностью Сургута от экономических центров страны.

Из приведенных выше характеристик Сургута становится очевидным, насколько стратегически важным и правильным оказался сделанный в 1964 году выбор застройки административно-хозяйственного центра ЗападноСибирской нефтегазоносной провинции. Уже в 1990-е гг. число жителей в Сургуте составило 255,8 тыс. человек, а в Нижневаратовске - меньше, 246,0 тыс. человек (48).

Тем не менее, несмотря на открытие в первой половине 1960-х гг. новых крупных месторождений нефти и газа, а также активную разработку планов градостроительного освоения новой нефтяной территории, системообразующая политика расселения прибывающих в Западную Сибирь трудовых ресурсов оставалась неопределенной. 
В отсутствии её в первой половине 1960-х гг. особое место занимала продолжительная дискуссия о характере и формах расселения специалистов и рабочих кадров в новой нефтегазовой провинции.

Тогда очень активно обсуждались две диаметрально противоположные точки зрения по этому поводу. Сторонники каждой из них руководствовались одними и теми же благими намерениями - предоставить нефтяникам и газовикам наилучшие бытовые условия при экономном расходовании средств.

Сторонники первого мнения, учитывая большую разбросанность производства, предлагали строить малые населенные пункты и располагать их ближе к месту работ. Многие специалисты высказывались против строительства на севере городов и поселков для проживания всех категорий трудящихся и предлагали бурение, строительство и эксплуатацию нефтяных месторождений, а также функционирование сопутствующей инфраструктуры осуществлять вахтовым или вахтово-экспедиционным методом. Капитальность зданий рекомендовалось ими выбирать в зависимости от продолжительности эксплуатации нефтепромыслов. Наиболее последовательные защитники такой модели расселения предлагали даже создавать передвижные поселки (49).

Основным аргументом в пользу поселков, рассредоточенных по месторождениям, выдвигалось максимальное приближение жилья к месту работы, возможность в кратчайший срок обеспечить им трудящихся и то обстоятельство, что эксплуатация нефтяных месторождений - дело временное. Как полагали сторонники этой точки зрения, оно будет охватывать период в 25-50 лет, и поэтому строить капитальные благоустроенные города, рассчитанные на более длительный срок эксплуатации, нецелесообразно. Главный смысл этой точки зрения состоял в том, чтобы не строить полноценных городов, а ограничиться посёлками и аэродромами, где все работы выполнялись бы силами прилетающих $\mathrm{c}$ «большой земли» специалистов. Строительство временных поселков сняло бы, по их мнению, и другую острую проблему - обеспечение занятости населения по мере сокращения кадров в основных отраслях нефтедобычи. Ученые называли такой подход к освоению «внешний вариант».

Другая группа специалистов основывалась на ином принципе освоения новой нефтегазовой территории и другой схеме расселения людей. Они подсчитали, что только $30 \%$ из общего числа занятых в нефтедобыче и ее обслуживании совершают постоянные поездки от места жительства к местам применения своего труда. В основном это буровики, эксплуатационщики и 
некоторая часть строителей. Около $20 \%$ трудящихся совершают эти поездки эпизодически. Основная же масса рабочих и служащих, 50\%, заняты на местах, расположенных в зоне функциональности городского транспорта и пешеходной доступности. Считалось, что быстрое увеличение работающих непосредственно в нефтедобыче будет наблюдаться в первое десятилетие эксплуатации месторождений. А затем последует их сокращение и переливание в другие отрасли производства (50). Поэтому они полагали, что все эксплуатационщики должны дислоцироваться в благоустроенных городах и поселках со всей необходимой инфраструктурой и обслуживать определенную группу месторождений. Такие базовые города севера Тюменской области должны стать опорными центрами внутрирегиональной вахты, позволяющей решать многие схожие проблемы групповой системы расселения по схеме «базовый город-вахта» (51).

По их мнению, важен был и другой, морально-политический фактор. Люди, приезжающие в эти трудные для жизни районы, должны были чувствовать, что они приехали сюда работать надолго, может быть, навсегда. Они должны быть уверены, что найдут здесь такие же условия жизни и такую же заботу о себе, как и в местах, откуда они приехали. Исключительное значение поэтому приобретало формирование в новых городах социальнобытовой инфраструктуры. Эта модель расселения получила название «внутренний вариант».

Дискуссия продолжалась на протяжении длительного времени. В ходе ее свое мнение высказали такие авторитетные ученые, как академики Н.Н. Некрасов, А.А. Трофимчук, Р.З. Сагдеев, А.Г. Аганбегян, целый ряд известных докторов наук. Хотя большинство ученых и практиков в ходе дискуссии высказались в пользу «внутреннего расселения», т.е. крупномасштабного городского строительства на осваиваемой территории, длительное время определенного стратегического решения высшими хозяйственными руководителями не принималось.

Затянувшееся теоретическое обсуждение этого вопроса откладывало практическое разрешение проблемы расселения трудящихся формирующегося Западно-Сибирского нефтегазового комплекса. Во многих случаях размещение людей в населенных пунктах Министерством нефтяной промышленности решалось волевым порядком, без достаточных технико-экономических обоснований, порой исходя из конъюнктурных соображений. 
Решающим стало слово Тюменского областного комитета партии. В 1966 году его первый секретарь Б.Е. Щербина инициировал проведение научнотехнической конференции, посвященной проблемам городского строительства в нефтегазоносных районах севера Тюменской области. Выражая точку зрения членов Тюменского обкома КПСС, большинства хозяйственных руководителей и специалистов проектных учреждений Тюменской области, Б.Е. Щербина выступил с конструктивной критикой позиции руководства Миннефтепрома СССР об отказе от вахтовых поселений в пользу небольших городов-спутников топливных месторождений. К этому времени Сургут все в большей мере концентрировал расселение и управление новым экономическим районом, доказывая преимущества создания благоустроенных городов-центров таких территорий. Б.Е. Щербина безоговорочно высказывался в пользу сосредоточения ресурсов и строителей в крупных городах, доказывая преимущества схемы расселения «базовый город-вахтовый поселок». Научнопрактическая конференция приняла соответствующее такому подходу решение, рекомендовав осуществлять централизованное расселение с преимущественным созданием благоустроенных городов-центров крупных нефтяных районов. В конце 1960-х гг., согласно схемам института «Гипрогор», поддержанным Тюменским обкомом КПСС, центрами нефтяных районов намечались базовые города Сургут, Урай, Нижневартовск и Южный Балык.

Эти рекомендации благожелательно были восприняты областной архитектурной корпорацией, о чем вспоминал главный архитектор Тюменской области В.А. Бешкильцев: «Дело в том, что, пока Сургут в значительной мере не был задействован, не были построены аэропорты, речные причалы, не было Сургутской ГРЭС и другого, нефтяники постоянно проявляли тенденцию строить мелкие города-поселки при каждом нефтяном месторождении» (52).

Однако при этом он с горечью констатировал, что в 1980-е гг. «из-за беспринципной позиции Госстроя РФ - «стройте, что хотите и где хотите» нефтяники все же добились строительства таких небольших городов и поселков, как Мегион, Лангепас, Южный Балык и других, расположенных в 50-60 километрах от базовых городов» (53).

Можно понять чувства заслуженного зодчего крупнейшего мегаполиса севера Западной Сибири, однако при этом надо иметь в виду то, что возникновение небольших городов-поселков имело объективный характер и было обусловлено рядом факторов, отличных от мотивов реализации генеральных планов развития больших городов, где главными побудительными 
обстоятельствами их развития были исторический и природный мотивы, а основной причиной пересмотра их генеральных планов являлось изменение экономической базы новых городов.

В свое время применительно характеру расселения трудящихся на Ближнем и Дальнем Севере Западной Сибири Московским институтом «Гипрогор» было разработано несколько вариантов. Первый, названный «центральный», был адресован крупным городам Сургуту, Нижневартовску, Нефтеюганску. Второй, «децентрализованный», касался поселений, создаваемых на каждом месторождении. Третий, «комбинированный» или «групповой», характеризовал города и поселки, организованные в агломерации (54).

В начальный период был прият централизованный вариант, так как не было дорог, не было инфраструктуры обслуживания аэропортов, речных портов и других ее элементов. Выручали вездеходы, катера, вертолеты. Это позволило создать центры энергетики, строительства, транспорта, культуры и социльно-бытового обслуживания. Ареал влияния крупных городов ограничивался пределами в 80-200 км (55).

Однако по мере расширения географии нефтяных месторождений, строительства железной дороги и автомобильных путей сообщения, траекторий полетов авиации улучшались условия их обустройства, электроснабжения, обеспечения теплом, водой и другими компонентами жизнедеятельности. Хозяйственные руководители в лице Миннефтепрома и Газпрома получали новые возможности освобождения рабочих от ежедневных, изнурительных, длительных переездов и увеличения их рекреационного времени. В 1980-1990-е гг. стали расти Мегион, Лангепас, Радужный, Ноябрьск, Муравленко, Губкинский и другие городские поселки (56).

Областной комитет партии, выполняя принятое в марте 1980 года совместное Постановление ЦК КПСС и Совета Министров СССР «О неотложных мерах по усилению строительства в районе Западно-Сибирского нефтегазового комплекса», запланировал большие объемы строительства жилья и объектов социальной сферы. За три годы намечалось в соответствии с установками ЦК КПСС построить более 6 млн.м ${ }^{2}$ жилья в комплексе с объектами социально-бытовой сферы (57).

В связи с этим было принято решение о строительстве ряда новых городов и рабочих поселков. Самые первые наметки по схеме расселения, созданию новых городов и поселков были выполнены в Тюмени Управлением 
архитектуры и представителями Госстроя России Л.А. Каировым и В.П. Афанасьевой, Госгражданстроем - Д.Н. Гришиным и Г.Н. Вороновой.

Эти эскизные разработки легли в основу принципов расселения, предложенных институтом «Гипрогор» в августе 1980 года, в соответствии с которым предусматривалось размещение новых населенных пунктов Ноябрьский, Тихий (Коротчаево), Муравлянковский, Вынгапурский, Пур-Пе в Пуровском районе Ямало-Ненецкого автономного округа, Хохряковский, Радужный, Лангепас, Когалым, Лянтор, Федоровский, Мамонтово, Пыть-Ях, Покачи, Островной, Нягань, Таллинский в Ханты-Мансийском автономном округе.

Одновременно была проделана огромная творческая работа по обеспечению намеченных объемов жилищного строительства проектноизыскательской документацией. Для этого Госстрой России привлек более 30 институтов страны и проектно-изыскательских организаций, которые провели необходимые геологические работы, осуществили топографические съемки и представили планировочные эскизы строительства новых поселений (58).

Выполнить грандиозную задачу было не под силу области. Для этого привлекались коллективы строителей Украины, Белоруссии, Прибалтийских республик, Молдавии, Грузии, Узбекистана, Таджикистана, городов Москвы, Ленинграда, Свердловска и Магнитогорска.

Для координации работ всех участников градостроительной деятельности по намеченным к строительству 17 новых поселений решением Тюменского облисполкома в 1980 году была создана межведомственная комиссия, в которую входили представители Госгражданстроя, Госстроя России, заказчиков, подрядчиков и проектировщиков. В течение 7 лет, с 1980 по 1987 годы, два раза ежегодно она проводила заседания, на которых рассматривались все вопросы застройки городов и поселков, связанные с обеспечением необходимых условий для нефтяников и газовиков.

На заседаниях комиссии подводились итоги проделанной работы, ставились очередные задачи строительства, определялись сроки их выполнения. Самыми тяжелыми были первые годы, начало проектирования и обустройство строительных площадок новых мест расселения, период становления. Только в 1980-1982 гг. было проведено 9 заседаний межведомственной комиссии. Незаменимую роль в организации ее работы сыграл находящийся непосредственно в эпицентре развернувшейся строительной эпопеи заместитель председателя комиссии, главный архитектор 
Тюменской области в эти годы, позднее Заслуженный архитектор России А.Н. Отрадный (59).

Возвращаясь в 1960-е гг., отметим, что тем временем в Западной Сибири неумолимо нарастали объемы нефтегазодобычи. Возрастали и масштабы их прогнозируемых запасов. XXIII съезд КПСС, состоявшийся в 1966 году, поставил задачу довести здесь добычу нефти к 1970 году до 345-355 млн. т., ежегодно обеспечивая ее прирост свыше 20 млн. т. На этой основе руководство государства сделало вывод о возможности создания в Западной Сибири нового крупнейшего в стране нефтегазодобывающего регио (60).

Городское строительство в Западной Сибири приобретало значение одной из важнейших стратегических народохозяйственных задач. Решающее значение для форсирования градостроительства в конце 1960-х гг. имело совместное Постановление ЦК КПСС и Совета Министров «О мерах по ускоренному развитию нефтедобывающей промышленности в Западной Сибири» от 11 сентября 1969 года. В нем прямо указывалось на необходимость «строительство жилых домов, объектов коммунального и культурно-бытового назначения вести на основе сосредоточения его во вновь создаваемых крупнейших городах с обеспечением максимального благоустройства их в контексте с промышленным строительством» (61).

В ходе планирования размещения базовых городов первоочередные пункты расселения определялись следующим образом: Сургут - для освоения Западно-Сибирской группы месторождений, Нижневартовск - для добычи промышленной нефти Самотлора и Мегиона, Урай - для Шаимской группы месторождений, Игрим и Березов - для группы Березовских месторождений, Надым, Пангоды, Уренгой, Новый порт, Каменный Мыс, Салехард, Лабытнанги - для газовых месторождений Ямала и Карского моря (62).

Весьма показательно, что при разработке «Гипрогором» гостов и схем данных промышленных планировок все указанные пункты подтвердились.

По мнению исследователя С.В. Литвинова, в истории градостроительного проектирования на севере Западной Сибири до 1968 года следует период «возникновения», а затем - «становления» (63).

Большую работу в решении этих задач на начальном этапе их проектирования сыграл институт «Башнефтепроект» (БашНИПИнефть) под руководством М.П. Мазина. Возглавляемый им коллектив имел большой опыт обустройства нефтяных территорий в Башкирии и Татарии, и он был успешно применен в ходе планирования городов Среднего Приобъя. Первые шаги 
городов Урай, Нефтеюганск и Нижневартовск осуществлялись по проекту архитектора Михаила Павловича Мазина (63).

После того, как БашНИПИнефть разработал системы сооружений промышленных объектов и первых рабочих поселков, во второй половине 1960-х гг. поселениями на вновь отведенных территориях занимались различные строительные институты. Московский институт ГИПРОГОР Госстроя РФ при активном участии архитекторов П.П. Джишкариани и Е.В.Чапкина осуществил планировку Сургут-Нижневартовского, Игрим-Березовского и Тюмень-Тобольского районов. Ленгипрогор Госстроя РФ усилиями архитекторов М.С. Козловского, А.И. Рыся, Е.С. Квашнина-Самарина, А.Г. Варзара и В.В.Прокопьевой разработал проекты детальной планировки городов Тюмени, Тобольска, Ялуторовска, Заводоуковска, Ишима и генерального плана Сургута.

ЛенНИИПградостроительства Госгражданстроя ССCP благодаря напряженной работе архитекторов С.И. Соколова, С.И. Крестьяшина и В.Д. Кадникова сумел разработать генеральные планы Нефтеюганска и Урая (64).

В Сургуте в основе возведения поселков строителей и нефтяников лежал план, разработанный институтом «Гипротюменнефтегаз». Поселок геологов строился на базе проекта института «Геологстройпроект». Для речников проектные работы выполнял институт «Сибгипроречтранс», для энергетиков «Уралтеплоэнергострой», для железнодорожников и транспортных строителей - «Сибгипротранс». Промышленные зоны проектировали Государственный институт градостроительства и инвестиционного развития «Гипрогор» и Московский проектный институт № 2 (ПИ-2) (65).

Проектный институт № 2 располагал высококвалифицированными специалистами, в полной мере владевшими профессиональными качествами ведущих сотрудников этого авторитетного института. Архитекторы Я. Дресс, Ю. Никологорский, В.Левин специфику севера знали очень хорошо, посвятив этому значительную часть своей жизни. Все будущие предприятия города, названные министерствами, они разместил на плане в двух зонах. В 10 км западнее Сургута, в «западном промышленном узле», должны были строиться деревообрабатывающие предприятия. На севере, вдоль территории Старого Сургута, Черного Мыса, на нескольких километрах планировалось размещение домостроительного комбината. Восточный промузел должны были составить предприятия по производству зданий и строительные организации, обслуживающие основные потребности нефтяников. На восточной окраине 
этой территории, ограниченной речкой Черной, должна была строиться Сургутская ГРЭС, работающая на попутном нефтяном газе. Для расположения города оставалась полоса земли, включавшая массив территории от речного порта и рыбоконсервного завода до реки Кедровки, вдоль основного русла реки Оби с охватом лесного массива, существующего аэродрома и застроенных территорий города Старый Сургут, поселков геологов, строителей, нефтяников.

Другой вариант плана предусматривал застройку территории западнее реки Кедровки, вдоль поймы Оби, между поселком Белый Яр и поселком НПУ «Сургутнефть», до западного промышленного узла между речкой Бардаковкой и болотом (66).

Переход к комплексному проектированию производственной инфраструктуры в увязке с градостроительным освоением Сургута сопровождался еще более активным подключением к работе проектного института № 2. Многие специалисты этого института проявили себя в ходе глубокой разработки научных обоснований, ценных рекомендаций и высококвалифицированного исполнения функций главного проектировщика. Я. Дресс, Ю. Николагорский, В. Левин очень хорошо знали специфику севера, посвятив этому региону значительную часть своей трудовой биографии (67).

После того, как БашНИПИнефгь разработал системы сооружений промышленных объектов и первых рабочих поселков, 22 февраля 1966 года бюро Тюменского обкома КПСС на своем заседании утвердило план регулирования текущей застройки города Сургута до 1970 года, представленный Московским проектным институтом «Гипрогор» (68). В соответствии с его расчетами, численность населения города в 1970 году должна была составить 60 тыс. человек. Весь объем нового капитального пятиэтажного жилищного строительства в размере 350 тыс. кв. метров и необходимые для него объекты соцкультбыта предполагалось разместить на свободных территориях между поселком нефтяников и западным промышленным узлом, растягивая город еще на добрый десяток километров западнее строящегося жилого района нефтяников. Как новая, так и существующая застройка, согласно плану, обеспечивались всеми видами инженерного оборудования и благоустройства: водопроводом, канализацией, энергоснабжением, дорожной сетью, озеленением.

«Гипрогор» учёл замечания и рекомендации Сургутского райкома КПСС и горисполкома в части уплотнения существующей застройки Сургута, а также выделения дополнительных территорий для двухэтажного и индивидуального 
жилищного строительства, соответствующего росту численности населения этого района, а также увеличению объемов социально-культурного и бытового строительства.

Московский проектный институт № 2 являлся также автором плана Сургутского промышленного узла, представлявшего собой схему размещения предприятий, складских и транспортных сооружений. Основным видом городского общественного транспорта был принят автобус. П.А. Мунарев в своих воспоминаниях ошибочно датирует это решение 1967 годом (69).

На основании принятого плана регулирования текущей застройки в Сургуте развернулось интенсивное оснащение площадок для массовой капитальной застройки города, обеспечение их всеми видами инженерного оборудования, строительство общегородской магистрали от жилого района нефтяников до Черного Мыса.

Однако уже тогда город, еще не начав строиться, растянулся километров на 16-18. В 1969 году журналист А. Нежный, побывавший в Сургуте, в опубликованном в «Новом мире» очерке «Города, которые мы строили» писал: «Поселки старались ставить там, где поудобнее. Но Сургуту вышло от этого великое неудобство: его растянули вдоль Оби на 15 километров, и стал он как худосочный подросток, сердце которого не успевает перегонять кровь во все уголки слабого тела... Сургут вообще представляет собой город несколько несообразный. Странный город - где ни тронь, всюду больно» (70).

Руководство и общественность города сначала робко, а затем все увереннее стали возражать против такого проекта «Гипрогора». Это мнение было рассмотрено сначала областным отделом архитектуры, а затем исполкомом областного Совета депутатов трудящихся. «Гипрогору» было дано задание разработать генеральный план строительства города с учетом этих замечаний. На споры и согласования ушло несколько лет (71).

К 1969 году Московским проектным институтом «Гипрогор» был, наконец, подготовлен «Генеральный план застройки города», руководителем авторского коллектива которого являлся П.П. Джишкариани (72). Этот план был рассчитан на 130 тыс. жителей. Он предусматривал строительство города на площадке между нынешним санаторием «Кедровый Лог» и поселком Белый Яр. На территории от «Кедрового Лога» до Старого Сургута, где уже начали обустраиваться первые пионерные базы нефтяников, газовиков и строителей, предполагалось разместить промышленную зону (73). 
Однако и этот план застройки Сургута не удовлетворял старожилов города. Согласно ему, город удалялся от Оби на 7 км заливной поймой, которая после весеннего паводка превращалась в болото. К растянувшемуся на 16-18 км городу добавлялось еще 10 км новой застройки. При этом уничтожался большой массив хорошего леса, в котором Сургут испытывал и без того большую потребность. Серьезные возражения вызывало и непомерное растягивание всех инженерных коммуникаций и их большая удаленность от восточной промышленной зоны, речного порта и будущей ГРЭС.

Выражая их мнение, первый секретарь Сургутского горкома КПСС В. Бахилов и председатель исполнительного комитета Сургутского городского Совета депутатов трудящихся П. Мунарев обратились в Тюменский обком КПСС с просьбой поменять площадку и перенести строительство города на территорию ныне существующего Сургута. В качестве аргумента ими выдвигалось наличие к тому времени на поселениях нефтяников, газовиков, строителей и энергетиков электроснабжения, теплоснабжения и водоснабжения, инженерных коммуникаций, дорог и канализации, «за которые можно было зацепиться» на начальном этапе масштабного городского строительства (74). После обсуждения позиции руководителей города сначала в областном отделе архитектуры, а затем на заседании бюро Тюменского обкома КПСС «Гипрогору» было дано задание разработать новый генеральный план застройки города Сургута в уже сложившихся границах (75).

Интересным дополнением к истории разработки генерального плана застройки Сургута являются воспоминания Владимира Аввакумовича Бешкильцева. Его имя, как главного архитектора Тюменской области в 1960-1976 гг., занимает особое место в истории проектирования и строительства Сургута. Своими первыми колышками, постановкой доминант в застройке город обязан именно ему.

Владимир Аввакумович мог выступить с искренним творческим несогласием в отношении решения любого вопроса. В.А. Бешкильцев, родившийся в 1930 году в Березово Ханты-Мансийского национального округа, хорошо чувствовал природный ландшафт Среднего Приобья и его иногда незаметные, на первый взгляд, особенности. Понимая, что главной композиционной осью пространства, оказывающей решающее влияние на планировочную структуру нового города, является река Обь, он категорически возражал против того, чтобы траектория застройки города начиналась от железнодорожной станции и проходила в стороне от исторической территории 
Старого Сургута, и настоял на том, чтобы в его структуру вошел Старый Сургут (76).

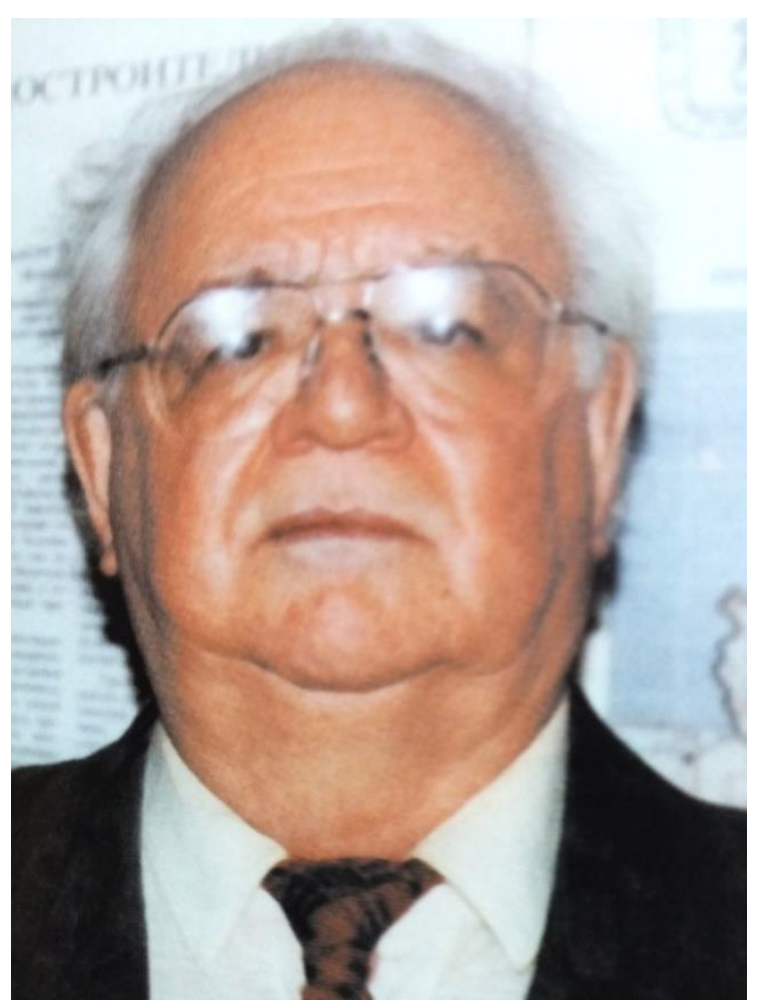

Владимир Аввакумович Бешкильцев, главный архитектор Тюменской области (1976-2001), председатель правления Тюменской областной организации Союза архитекторов СССР и РФ

Владимир Аввакумович в своих воспоминаниях так воспроизводил судьбоносное для будущего Сургута событие - утверждение генерального плана его застройки в 1969 году, проходившее, как он писал, на заседании областного комитета КПСС: «Многие выступали и рекомендовали проект генерального плана развития Сургута утвердить. В заключение Б.Е. Щербина предоставил последнее слово мне. Я встал и сказал, что материал от утверждения надо отложить, назвав лишь одну причину: проектный институт предлагает бросить исторический Сургут и уйти с застройкой на Белый Яр, в 20 км от Сургута, уйти от реки Оби. Гробовое молчание продолжалось буквально минут пять» (77). Было принято решение вернуть проект генерального плана на доработку. Он был окончательно утвержден на 
заседании Госстроя РСФСР в 1970 году и отличался большей компактностью городской территории (78).

Таким образом, открытие нефтегазоносной провинции в Западной Сибири обусловило интенсивный приток населения на территорию Среднего Приобья. Для его закрепления на рабочих местах и организации эффективной работы по обеспечению ее промышленного освоения необходимо было принять научно обоснованную модель расселения трудовых ресурсов. На состоявшихся в Тюмени в середине 1960-х гг. научно-практических конференциях был сделан выбор в пользу строительства крупных населенных пунктов с расселением нефтяников и газовиков по схеме «базовый город-вахтовый поселок».

Во второй половине 1960-х гг. Башкирским научно-исследовательским институтом проектирования (БашНИПИ нефть) под руководством М.Н. Мазина было осуществлено планирование размещения промышленных объектов и первых рабочих поселков, а чуть позже различными строительными институтами представлены генеральные планы развития Сургута, Урая, Нефтеюганска и Нижневартовска с учетом компактности застройки, сближения основных функциональных зон, транспортных и инженерных коммуникаций, сохранения природных рекреационных зон.

\section{Примечания}

1. Нефть и газ Тюмени в документах (1901-1905 гг.). Свердловск. Урал. кн. изд. 1971. Т.1.С.238-241.

2. См. подробнее: Колева Г.Ю., Комгорт М.В. Проблема повышения уровня индустриального развития Западной Сибири и проект строительства Нижнеобской ГЭС // Вестник Томского государственного университета.2008. № 3.С. 85-91; Некрасов В.Л. Нефтегазовый комплекс СССР во второй половине 1950-х - первой половине 1960-х гг.: институциональные аспекты развития // Экономическая история: Ежегодник. 2009. М., 2009. С. 220-223; Некрасов В.Л., Стафеев О.Н. Проект Нижне-Обской ГЭС (1958-1963 гг.): лоббирование, создание каолиции интересов, оппортунизм // Вестник Сургутского государственного педагогического университета. 2012. № 4. С.175-181; Стафеев О.Н. Проекты индустриального обновления регионов севера Западной Сибири (1950-е - первая половина 1960-х гг.) // Вестник Сургутского государственного педагогического университета. 2010. № 3. С. 63-72. 
3. Решения партии и правительства по хозяйственным вопросам. 19171967 гг. Сборник документов за 50лет. В 5-ти тт. Т.5. 1962-1965 гг. М.,1968. C.427-433.

4. Там же.

5. Карпов В.П., Панарин С.М. О месте Западно-Сибирсого нефтегазового региона в истории отечественной нефтегазовой промышленности // Социальноэкономическое развитие Западно-Сибирского региона: история и современность. Тюмень, 1993. С.45.

6. ГАСПИТО. Ф.124.Оп.140.Д.31.Л.281.

7. Нефть и газ Тюмени в документах. Свердловск, 1971. Т.1. С.235.

8. ГАСПИТО.Ф.П107.Оп.1. Оп.2112. Л.18.

9. Там же.

10. Донгорян Ш.С. Взгляды на градостроительство на севере Западной Сибири // История и перспетивы градостроительного освоении территории Севера. Западно-Сибирский нефтегазовый комплекс. М.,2004. С.189.

11. Путинцев Э.П. Комплексная концепция северного градостроительства: автореф. дисс...доктора архитектуры. 18.00.04. М., 2005.С.4.

12. Там же. С.7.

13. Унжаков В.И. Пока город строится, он живет // Новый город.2003. 9 августа

14. Донгорян Ш.С. Взгляды на градостроительство на севере Западной Сибири // История и перспективы градостроительного освоении территории Севера. Западно-Сибирский нефтегазовый комплекс. М., 2004. С.189.

15. История и перспективы градостроительного освоения территории Севера. Западно-Сибирский нефтегазовый комплекс. М.,2004. С.239.

16. Там же. С.241

17. Там же.

18. Там же. С.237.

19. Там же. С.239.

20. Архивный отдел администрации города Нижневартовска (АОАГН). Ф.43.15 ед.хр.1965-1974).

21. История и перспективы градостроительства...С.331.

22. Там же. С.262

23. Там же. С.259.

24. Режим доступа: schoolsience.ru 5 /2/ 35847

25. История и перспективы градостроительства...С.241. 
26. Там же.

27. Там же. С.237.

28. Там же. С.239.

29. Там же. С.259.

30. Там же. С.389.

31. АОАГС.Ф.90.Оп.1.Д.30.Л.3-4

32. Тимошенко А.И. Государственная политика формирования и закрепления населения в районах нового промышленного освоения Сибири в 1950-1980-е гг.: планы и реальность. Новосибирск: Сибирское научное издательство, 2009. С.130.

33. Юрасова М., Юрасов Г., В.И. Муравленко. Свердловск, 1986. С.99.

34. Там же. С. 100.

35. Там же. С.99.

36. Там же. С.99.

37. Там же. С.122.

38. АОАГС.Ф.90.ОП.1.Ф.30.Л.3.

39. Нечушкин А.Ф. Комментарии и воспоминания // Годы и люди. Сургутской Грэс-1.М., 1997.С.20

40. ГАСПИТО.Ф.2010.Оп.1..159.Л.12-13.

41. Там же.

42. Мунарев П.А. Так было, так начиналось. Сургут, 2008. С.68.

43. Салманов Ф.К. Сибирь-судьба моя. М., 1988. С.188.

44. Стась И.Н. Стать горожанином: урбанизация и население в нефтяном крае.1960-е-нач.1990-х гг. Курган, 2018. С.42.

45. Югра.1997.№ 30.С.9.

46. Там же.

47. Там же

48. Стась И.Н. Указ.соч. С.43.

49. ГАСПИТО. Ф.124. Оп.191. Д.73. Л.

50. Там же.

51. Там же.

52. История и перспективы градостроения ... С.199.

53. Там же.

54. Там же. С.267.

55. Там же. С.195.

56. Там же. С.267. 
57. Цит. по: История и перспективы градостроительства... С.262

58. Там же.

59. Там же. С.264

60. Материалы ХХ111 съезда КПСС. Политиздат. М., 1966. С.13.

61. Постановление ЦК КПСС и Совета Министров СССР «О мерах по ускоренному развитию нефтедобывающей промышленности Западной Сибири». 11 сентября 1969 г. // КПСС в резолюциях и решениях съездов, конференций и пленумов ЦК. Т. 10.М., 1972. С. 131.

62. Практика строительства в Западно-Сибирском нефтедобывающем регионе // История и перспективы градостроительного освоения территорий Севера. М., 2004. С. 155-156.

63. Литвинов С.В. Архитектурно-планировочное развитие городов Среднего Приобья (исторический анализ и решения). Автореф. дис. ... канд. арх-ры. СПб., 2007. С. 8.

64. История и перспективы градостроительства... С.237.

65. Там же.

66. Там же. С.156.

67. Там же. С.239

68. ГАСПИТО.Ф.124. Оп.182. Д.18. Л.6-7

69. Мунарев П.А. Указ.соч. С.67.

70. Нежный А. Города, которые мы строим: о проблемах градостроительства. Заметки публициста // Новый мир. 1969. №10. С.188-206

71. Мунарев П.А. Указ.соч. С.67

72. Там же.

73. Мельниченко М. Виктор Унжаков: «Я не делал карьеру. Я просто работал» // Сургутские ведомости.2003.10 ноября.

74. Там же.

75. Мунарев Указ. соч. С.68.

76. Из воспоминаний архитектора В.В. Прокопьевой // История и перспективы градостроения... С. 251.

77. Из воспоминаний главного архитектора Тюменской области в период становления ЗСНГ В.А. Бешкильцева // История и перспективы градостроения... С.199.

78. Мунарев П.А. Указ.соч. С.68. 


\section{ГЛАВА 2. \\ ДЕЯТЕЛЬНОСТЬ ПРОЕКТИРОВЩИКОВ И АРХИТЕКТОРОВ ХМАО-ЮГРЫ В 1970 - 1980 ГГ.}

Напомним, что производственная структура севера Тюменской области изначально формировалась по узкоотраслевому направлению нефтедобычи. Первым автором разработок системы сооружений нефтегазового комплекса, промплощадок и пионерных рабочих поселков естественным образом являлся БашНИПИнефть (Башкнефтепроект). Промышленные площадки и производственные сооружения были началом градостроительства во всех новых населенных пунктах Западной Сибири в период ее нефтегазового освоения 1960-1990 гг.

Однако переход на севере Западной Сибири в конце 1960-х - начале 1970-х гг. к комплексному проектированию производственной инфраструктуры в увязке с градостроительным освоением новой территории, разработке научных обоснований генерального планирования городов потребовал принципиального отказа от изначального формирования производственной структуры в строительной политике севера Тюменской области на основе узкоотраслевого принципа нефтедобычи. Для этого потребовались теперь иные специалисты в области архитектуры и проектно-изыскательских работ.

Поэтому 12 января 1968 года в памятной записке Председателю Госстроя СССР И.Т. Новикову Тюменский обком КПСС выразил свое неудовлетворение по поводу планировочной работы Башкирского нефтепроектного института. Он обращал внимание на невысокий профессиональный уровень градостроительной документации, разрабатываемой этим институтом, и напоминал о неоднократных просьбах передачи разработки генпланов и детальных планировок новых городов от института «Башнефтепроект» специализированному Ленинградскому зональному научно-исследовательскому институту по экспериментальному проектированию городов севера «ЛенЗНИИЭПу» (1).

14 мая 1970 года Тюменский областной Совет депутатов трудящихся на основании Приказа Госкомитета по гражданскому строительству и архитектуре при Госстрое СССР и Госстрое РСФСР от 18 марта 1970 года возложил обязанности головных проектных организаций по разработке комплексной проектной документации жилищно-гражданского строительства, включая рабочие чертежи и авторский надзор, в Сургуте, Надыме и Уренгое на 
ЛенЗНИИЭП; Нефтеюганске, Урае и Южном Балыке - на ЛенНИИ гражданского строительства; в Нижневартовске - на СибЗНИИЭП; в Салехарде, Лабытнанги, Харпе - на Ленгипрогор (2).

В принятом постановлении Тюменского областного Совета депутатов трудящихся был определен порядок организации филиала ЛенЗНИИЭПа в Сургуте, который был открыт в 1970 году. Его первым директором был назначен Евгений Борисович Никифоров, главным инженером - Н.С. Пукач. С ними приехали из Ленинграда архитекторы В.И. Лопоногов, В.В. Ванин и И.А. Гургенов, инженеры Д.Г. Дейч и А.А. Миронов (3).

К этому времени первые руководители Тюменской области Б.Е. Щербина и А.К. Протазанов пришли к выводу о половинчатом характере такого решения и предлагали сосредоточить проектирование всех гражданских объектов в институте «Тюменьгражданпроект» и его «частных мастерских» в Сургуте, Урае и Нижневартовске. Такой шаг администрации области позволил существенно приблизить проектирующие организации непосредственно «к месту событий», сделать их продукцию более реалистичной, точнее учитывать региональную специфику, существенно улучшить работу по подготовке проектно-сметной документации, осуществлению авторского надзора за ходом строительства, оказанию помощи строительным организациям. На базе ЛенЗНИИЭПа в 1986 году будет открыт Западно-Сибирский зональный научно-исследовательский институт экспериментального проектирования (ЗапСИБЗНИИЭП) (4).

Ленинградский зональный научно-исследовательский институт экспериментального проектирования (ЛенЗНИИЭП) был создан в 1963 году как главная организация по проектированию и строительству в «северной зоне» страны. Он унаследовал лучшие традиции крупнейших проектных научноисследовательских институтов и стал достойным преемником Академии строительства и архитектуры, базировавшейся тогда в Ленинграде.

Многие годы институт возглавляли выдающиеся инженеры и ученые А.В. Карагин и В.В. Судаков, крупный зодчий, талантливый архитектор С.Б. Сперанский. Последние десятилетия его генеральным директором являлся. Н. Верещагин, прошедший в институте большой путь от техника-конструктора до руководителя института (5).

После открытия за Уралом крупнейших в стране месторождений нефти и газа важнейшей задачей ЛенЗНИИЭПа стало проектно-изыскательское и архитектурное обеспечение крупномасштабного капитального строительства, 
развернувшегося в обширных нефтегазоносных районах Западной Сибири. В своей деятельности Сургутский филиал ЛенЗНИИЭПа испытывал существенные кадровые и финансовые трудности. В 1978 году в его штате не хватало 40 специалистов. Серьезной проблемой являлась текучесть кадров. В 1976-1978 гг. из-за неудовлетворительной заработной платы из филиала уволилось 127 человек. Филиал стал поставщиком специалистов в другие организации города, где коэффициент на зарплату был выше. Недопустимо затягивалось в Сургутском филиале ЛенЗНИИЭПа открытие научного подразделения (6).

Тем не менее, институт первым начал последовательно осуществлять масштабную застройку территории городов севера Западной Сибири, определяя их нормативную базу и градостроительную политику, дислокационный и архитектурный образ. Многие архитекторы, инженеры и ученые института получили всероссийскую известность в процессе разработки новаторских проектов. Даже те из проектов, которые остались нереализованными, оказали большое влияние на архитектурно-строительный процесс в стране.

Новаторский градостроительный подход филиала ЛенЗНИИЭПа проявлялся в типовых и индивидуальных проектах отдельных сооружений, их комплексов и всего города. Сургут в полной мере можно назвать продуктом деятельности института как его генерального проектировщика со всеми присущими городу архитектурно-строительными плюсами и минусами. Только за первые семь лет работы филиал ЛенЗНИИЭПа совместно с субподрядными организациями выполнил объем проектно-изыскательных работ на сумму свыше 5,5 млн. рублей. По сравнению с 1971 годом его программа возросла в 4.5 раза и составила в 1978 году 1 млн. 543 руб. по генподряду и 890 тыс. руб. за счет «собственных сил». За этот период коллектив филиала выдал проектносметную документацию на строительство жилых домов общей площадью свыше 700 тыс. кв.м., школ на 10 тыс. мест, детских садов на 5 тыс. 600 мест, предприятий торговли на 9 тыс. 835 кв.м. рабочей площади, предприятий общественного питания на 1 тыс. раздаточных места, библиотек на 200 тыс. томов, двух плавательных бассейнов, базы зимних видов спорта, фирменного магазина «Океан» и ряда других жизненно важных для города объектов. В 1978 году филиал завершил большую работу по проектированию детальной планировки восточного жилого района (7).

В 1979 году, выполняя Постановление ЦК КПСС и Совета Министров СССР от 9 феврала 1978 года, ЛенНИИПградостроительства разработал новый 
генеральный план города Сургута. Его особенностью являлось то, что он создавался на реальной основе - на базе неорганизованной застройки пионерных поселений. Поэтому, кроме нового строительства, им предусматривалось исправление нарушений градостроительной дисциплины создателями первоначальных поселений - ликвидация случаев нарушения функционального зонирования, реконструкция территории обских набережных и малоценной малоэтажной застройки центрального района пионерной застройки. К недостаткам планировочных решений нового генплана можно отнести трассировку магистрали непрерывного движения западного планировочного района, что фактически отсекало его северную часть от общегородского центра и акватории Оби. В нем недостаточно были представлены композиционные и визуальные связи селитебной зоны общегородского центра с приречной территорией, слабо проработаны планировочные связи Сургута как портового города с акваторией Оби, а также вопросы освоения и благоустройства пойменной территории Оби с целью превращения ее в рекреационную зону. План содержал ограниченные возможности развития города в западном направлении в связи с тем, что сплошные зеленые массивы, занимающие предназначенные под западный планировочный район территории, являются фактически единственными зелеными насаждениями пригорода, а также пересечение основного лесного массива в бассейне реки Саймы транспортным направлением.

Многие архитекторы, инженеры и ученые института в этих непростых условиях решения объёмно-пространственной композиции города получили всероссийскую известность в процессе разработки в нем многих новаторских проектов. Исправлению недостатков пространственно-планировочного решения комплекса общегородского центра послужило проведение в 1979 году конкурса на проект центра Сургута. Специалисты филиала ЛенЗНИИЭПа проделали эффективную работу по корректировке центрального ядра города, где были значительно улучшены как планировочные, так и объемнокомпозиционные характеристики этого важного городского комплекса. Даже те из них, которые остались нереализованными, оказали большое влияние на архитектурно-строительный процесс не только в новом городе, но и в стране (8).

Трудно переоценить вклад в работу Сургутского филиала ЛенЗНИИЭПа Семена Владимировича Билецкого. Профессиональную деятельность он начал в 1959 году в качестве техника. После службы в армии в 1962-1967 гг. учился 
во Львовском политехническом институте на факультете «Промышленное и гражданское строительство». В Сургуте начал работать с 1966 году в составе студенческого строительного отряда. После окончания института работал начальником производственного отдела СУ-9 треста «Сургутгазстрой». В августе 1971 года С.В. Билецкий был избран заместителем председателя Сургутского горисполкома, а в сентябре 1973 года назначен директором Сургутского филиала ЛенЗНИИЭП (9).

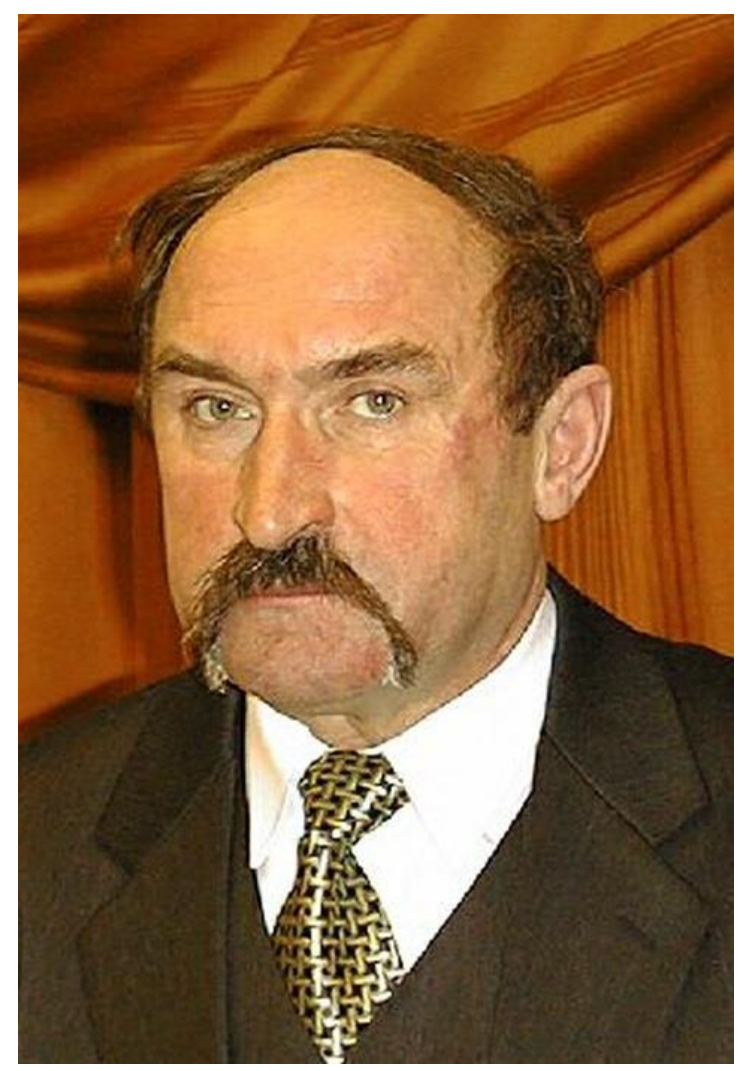

Семен Владимирович Билецкий, заместитель Председателя Сургутского горисполкома (1971-1974), директор Сургутского филиала Ленинградского зонального научно-исследовательского института экспериментального проектирования - ЛенЗНИИЭПа (1974-1985), директор Западно-Сибирского зонального научно-исследовательского института экспериментального проектирования ЗапСибЗНИИЭП (1985-2000)

Уже тогда, движимый логикой современного градостроительства, C.В. Билецкий в противоречивых условиях командно-административного управления строительным комплексом Западной Сибири, ведомственно- 
отраслевого характера застройки новых городов последовательно утверждал в Сургуте современные принципы архитектурных и планировочноизыскательских решений. В 1978 году на сентябрьском пленуме Сургутского городского комитета КПСС директор филиала ЛенЗНИИЭПа С.В. Билецкий настоятельно заявлял, что «прогрессивные градостроительные замыслы успешно реализуются только при тесном содружестве единого генерального заказчика, генерального подрядчика, генерального проектировщика» (10). Позже усилиями проектировщиков и инженеров удалось соединить их в единое целое и придать городу на основе генерального плана логическое оформление.

Под руководством С.В. Билецкого, проработавшего в должности директора института 26 лет, было спроектировано более $80 \%$ жилья и соцкультбыта Сургута и поселков городского типа Сургутского района: Лянтора, Федоровского, Пойковского, Барсово. Он был один из немногих специалистов, которые до тонкостей знали проблемы проектирования, реконструкции и строительства в Сургуте.

В возглавляемом им коллективе активно и творчески трудились «поставивший на ногу» многие здания города конструктор Э.К. Чиженков, работавшая в институте со дня его основания конструктор А.А. Ванина, участник разработки почти половины жилых массивов Сургута архитектор В.Б. Блинов и другие сотрудники Сургутского филиала ЛенЗНИИЭПа, благодаря которым Сургут из разрозненных небольших ведомственных поселений превратился в современный город (11).

О роли филиала ЛенЗНИИЭПа в истории Сургута свидетельствует то, что исследователи выделяют четыре этапа в его развитии. Первый, исторический, с 1594 года до начала освоения нефтегазовых месторождений. Второй, начало 1960-конец 1970-х гг. характеризовался бурным ростом, высокими темпами ведомственного строительства, возникновением отдельных поселков нефтяников, строителей, железнодорожников, энергетиков. Третий, начало 1980-х - конец 1990-х гг., включал в себя развитие городской инфраструктуры, формирование главных улиц города и его целостной застройки в соответствии с Генеральным планом ЛенЗНИИЭПа. Четвертый, 2000 г. - настоящее время, был связан с дальнейшим развитием инфраструктуры с охватом территории от аэропорта до Оби, строительством уникальных зданий по индивидуальным проектам, внедрением новых строительных технологий на предприятиях города, привлечением иногородных и иностранных фирм на конкурсной основе (12). 
Для более полного осуществления функций генпроектировщика в ЛенЗНИИЭПе была сформирована группа компетентных специалистов. Ее руководителем был назначен опытный архитектор В.И. Унжаков. В состав группы были включены архитектор Б.М. Абелис, инженер Р.К. Миляева и техник Г.А. Воробева (13).

Большую помощь в проектировании города оказывали Союз архитекторов РСФСР в лице Л.Г. Рочегова и Б.С. Нелюбина, а также Академия архитектуры и строительства, представляемая Л.В. Хихлухой и А.Н. Виноградовым (14).

На взгляд В.Г. Бердяева, являвшегося в 2000 году руководителем персональной творческой мастерской «Акцент», главным архитектором «СургутНИГТИнефти», председателем правления Сургутской организации Союза архитекторов России, председателем окружного территориального лицензионного архитектурного центра ХМАО-Югры, до этого 25 лет занимавшегося архитектурой в Сургуте: «Сургут в плане архитектуры был далеко не самый безликий среди молодых городов страны» (15).

Такой же точки зрения придерживался и первый вице-президент Союза архитекторов России Б.С. Нелюбин, посетивший Сургут в 2000 году. Они подчеркивали, что не следует забывать об острой необходимости высоких темпов строительства в условиях катастрофической нехватки жилья. В то время было не до архитектурных излишеств, а «моспроект» являлся самым дешевым, хотя и абсолютно не приспособленным для северных условий жильем.

Несмотря на то, что нефтяники, энергетики, строители, геологи самостоятельно возводили свои микрорайоны, сотрудники филиала уделяли архитектуре застройки особое внимание (16). Даже в то время местным архитекторам удавалось реализовывать в строительстве необычные решения. К ним можно отнести закругленные дома. Благодаря разработчикам их проектов В. Блинову, А. Агабабову и другим, привычные коробки 164-й серии стали смотреться по-новому и придали некоторым улицам и площадям особый вид (17).

В Сургуте строились и весьма оригинальные сооружения. При непосредственном авторстве сургутского архитектора В. Каштанова были возведены здания кинотеатра «Аврора» и ДК «Энергетик». В разработке нескольких вариантов проекта высотного здания «Сургутгазпрома» принимал участие сургутский архитектор А. Мордяков. Здание музыкальной школы в микрорайоне нефтяников построено по проекту М. Малинина, В. Турханов является автором проекта музыкальной школы на улице 50-летия ВЛКСМ, 
дизайн ДК «Магистраль» в микрорайоне железнодорожников разработан отцом и сыном Бердяевыми, магазин автозапчастей на перекрестке улиц Профсоюзной и Пушкинской под названием «Старый замок» спроектирован кандидатом архитектуры В. Соловьевым в содружестве со своим сыном Сергеем и В. Макелоном. Много сил и таланта вложил в проект здания Департамента жилищно-коммунального хозяйства безвременно ушедший из жизни В. Барзаковский (18).

Заметный вклад в разработку архитектурных проектов Сургута на рубеже 1990-2000 гг. внесли и югославские архитекторы. Так, например, весьма оригинально и достаточно современно выглядит спроектированное ими и построенное методом подъема этажей новое здания офиса «Сургутнефтегаз» (19).

В значительной степени реализация прогрессивных задач градостроения в Сургуте зависела от высокого профессионализма, принципиальности и авторитета главных архитекторов города. В середине 1960-х гг. почти во всех городах и районах Тюменской области были введены должности городских и районных архитекторов. Была увеличена численность аппарата Управления главного архитектора города Тюмени и областного отдела по делам строительства и архитектуры. Однако на начальном этапе градостроения в связи с отсутствием специалистов должности архитекторов ряда таких городов, например, как Сургут, Нефтеюганск и даже Тобольск, а также всех районов области занимали работники, не имевшие специального образования. Обращая внимание на это, 21 мая 1968 года секретарь Тюменского обкома КПСС А. Протазанов в служебной записке Председателю Государственного комитета Совета министров РСФСР по делам строительства и архитектуры сообщал: «Обком КПСС просит Госстрой РСФСР для укрепления местных органов архитектуры направить в 1968 году в Тюменскую область из числа оканчивающих архитектурные вузы 15 специалистов». (20) 10 июня 1968 года Госстрой РСФСР отвечал А. Протазанову: «Сообщаем Вам, что из числа специалистов, окончивших учебные заведения в 1968 году, Тюменской области выделено 15 специалистов с высшим образованием и 16 со средним специальным. Выделить дополнительно в настоящее время не представляется возможным. При распределении специалистов, окончивших высшие и средние учебные заведения в 1969 году, Ваша просьба будет учтена» (21).

В исследуемый период должность главного архитектора города Сургута занимали А.А. Асеева (1967-1968 гг.), О.В. Шока (1969-1972 гг.), Б.М. Бейдер (1972-1974 гг.), В.И. Арзамасцев (1974-1976 гг.), Б.М. Абелис (1976-1979 гг.), 
А.П. Аболонкин (1979-1986 гг.), В.Г. Груханов (1986-1989 гг.), В.И. Унжаков (1989-2000 гг.), М.А. Чураков (3 месяца в течение 2000 года), М.В. Данилов (2000-2004 гг.), А.В. Усов (с 2004 года) (22).

Именно они под руководством главного архитектора Тюменской области А.Н. Отрадного оказывали компетентное влияние на принятие решений по всем вопросам городского строительства, начиная с акта утверждения представляемых проектов до эксплуатации и реконструкции зданий. Главные архитекторы обеспечивали порядок застройки города в соответствии с генеральным планом, преодолевали стихийность и ведомственность в его строительстве, обеспечивали профессиональное управление градостроительной территории.

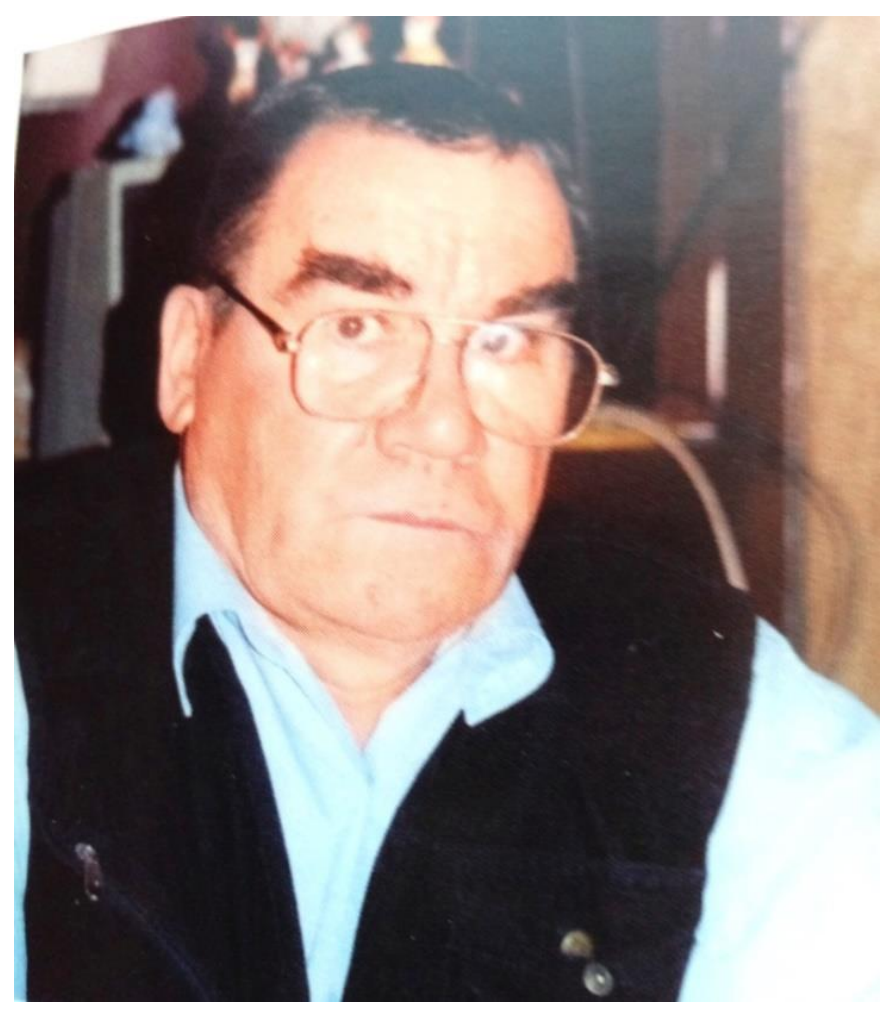

Анатолий Николаевич Отраднов,

главный архитектор института «Тюменьгражданпроект» (1966-1976), главный архитектор Тюменской области (1976-2001)

В Сургуте особое значение роль главного архитектора приобрела в период наиболее интенсивного строительства города, пик которого пришелся на 1989 год, когда было введено в строй 340 тыс. кв. м. жилья, а также в наиболее трудные 1990-е гг., в течение которых, несмотря на «строительный 
обвал» в регионе, Сургут возводил две трети жилищного фонда всего ХантыМансийского автономного округа. Неслучайно то, что именно в Сургуте в декабре 1985 года было создано одно из немногих в стране отделение Союза архитекторов СССР (23), а чуть позже главному архитектору г. Сургута, выпускнику факультета архитектуры Уральского политехнического института имени С.М. Кирова, в свое время приглашенного на эту должность Л. Рокецким, человеку, как он сам иронизировал, «с мухоморным характером», Виктору Ивановичу Унжакову, были присвоены высокие звания «Заслуженный архитектор Ханты-Мансийского автономного округа» и «Заслуженный архитектор Российской Федерации» (24).

Наиболее злободневными для архитекторов строящихся городов были вопросы рациональной конструкции жилых зданий для северных районов Западной Сибири. Они обсуждались на научно-практических конференциях по проблемам градостроительства в 1966 и 1968 годах в Тюмени с участием заинтересованных министров, представителей Госстроя и Госплана СССР (25). Большую активность в создании оптимального проекта жилья для северян проявляли Тюменский обком КПСС и Министерство газовой промышленности. 15 декабря 1967 года в одном из писем Министерство газовой промышленности сообщало секретарю Тюменского обкома КПСС А. Протазанову, что «оно поддерживает предложение Тюменского обкома КПСС о рассмотрении проектирования жилых домов и жилых комплектов, предназначенных для строительства поселков в нефтегазоносных районах» (26).

Члены Тюменского обкома считали, что действующие серии полносборочных жилых домов по своим планировочным и конструктивным решениям, а также принятой в них внутренней высотой 2,5 метра не учитывают специфики и климата условий северных широт Западной Сибири. Они справедливо полагали, что суровые климатические условия этих районов, где зимой температура достигает минус 40-45 градусов, а летом выпадает значительное количество осадков, вызывают необходимость более длительного пребывания в жилых помещениях, что требует создания максимума удобств и благоустройства для работающих и их семей, и в первую очередь увеличения объема помещений. Поэтому 9 июля 1968 года в служебной записке председателю Госстроя СССР И. Новикову секретарь Тюменского обкома КПССЕ. Огороднов писал: «Учитывая эти обстоятельства, Министерство газовой промышленности и Тюменский обком КПСС убедительно просят Вас, в порядке исключения, разрешить увеличение внутренней высоты жилых зданий, 


\section{ГОРОДСКОЕ СТРОИТЕЛЬСТВО В ХАНТЫ-МАНСИЙСКОМ АВТОНОМНОМ ОКРУГЕ - ЮГРЕ (к.1950-х - сер.1990-х г2.)}

сооружений в северных газовых и нефтяных районах Тюменской области до 2,7 метра» (27).

2 декабря 1968 года эту просьбу дублировал первый секретарь Тюменского обкома КПСС Б.Е. Щербина: «Учитывая тяжелые климатические условия в этих районах, обком КПСС просит Госстрой СССР разрешить строительство жилых домов серии 1-467-А с высотой этажа 2,7 метра» (28).

Госстрой СССР позитивно реагировал на мнение партийного руководства области. Ленинградскому зональному научно-исследовательскому институту экспериментального проектирования (ЛенЗНИИЭПу) было дано задание не только поднять потолок в проекте серии 1-467-А, но и приступить к специальному проектированию пятиэтажного крупнопанельного дома для северян.

Когда проект такого дома, подготовленный ЛенЗНИИЭПом, был готов, его направили на согласование заинтересованным организациям для утверждения в Тюменский обком КПСС. Однако первый секретарь областного комитета партии Б.Е. Щербина «камня на камне» не оставил от представленного проекта. Борис Евдокимович в принципе не был согласен с ним. Суть его критики состояла в том, что проект не содержал «идеи закрепления человека на севере». По его мнению, решению этой задачи во многом должен способствовать более комфортный вариант квартиры для северян.

Борис Евдокимович мечтал о такой квартире, из которой человеку, приехавшему работать на север, не хотелось бы уезжать. Сохранился документ, в котором были зафиксированы требования Б.Е. Щербины к такому варианту жилья.

Во-первых, из-за недостатка кислорода на севере он рекомендовал увеличить объем квартиры, полагая, что потолки у нее должны быть 3 метра, а не 2,5, как предполагалось. Во-вторых, учитывая сырой климат и условия работы нефтяников, в каждой квартире он советовал предусмотреть сушилки. Он был категорически против строительства однокомнатных квартир, считая, что одинокий человек должен жить в общежитии, а для семьи из двух человек однокомнатной квартиры недостаточно. Он считал, что в проекте должны доминировать четырехкомнатные и трехкомнатные квартиры с двумя санузлами. На первом этаже каждого подъезда полагал Борис Евдокимович необходимо предусмотреть просторные помещения для проведения совместных торжеств, свадеб, юбилеев. При входе в подъезды он рекомендовал включить в 
проект оборудованные места для хранения колясок и велосипедов, учитывая прогнозы высокой рождаемости в северных городах (29).

Все эти предложения первого секретаря обкома, безусловно, были приняты. Однако в мае 1971 года он был вынужден признать, что в Среднем Приобье, где в силу суровых природно-климатических и сложных инженерногеологических условий, отсутствия собственной индустриальной базы и постоянно действующего транспорта для осуществления перевозок строительных материалов и конструкций удорожание строительства, по сравнению с центральной полосой, составляло 2,5 раза, освоение 1 га территории - 1,7 раза, стоимость $1 \mathrm{м}^{2}$ жилой площади в деревянном доме превышала 180 рублей, а в капитальном помещении - 280 рублей в среднем по СССР (30), он с горечью вынужден был признать, что «с такими хоромами, когда на каждого работающего приходится по 70-100 квадратных метров жилья, на севере жилищной проблемы не решить» (31).

Этот роскошный проект был заменен на новый, менее комфортный, и тоже не без участия Б.Е. Щербины. После того как он был назначен министром Миннефтегазстроя СССР, неся ответственность за решение жилищной проблемы всех нефтяников и газовиков страны, министр был вынужден понизить «тюменскую планку». Щербина-реалист наступал на горло собственной песне.

Сургутские архитекторы и проектировщики последовательно искали пути решения внедрения прогрессивных технологий в домостроительное производство и адаптацию своей продукции к суровым климатическим условиям Среднего Приобья. Ведущие специалисты понимали, что главное требование к строительству на севере заключается в максимальной сборности элементов, превращении строительной площадки в монтажную, максимальном облегчении конструкций и повышении их вариабельности и взаимозаменяемости. В начале 1970-х гг. большое признание в ряде северных районов страны, Певеке, Анадыре и других, получила система «Мобиль», предложенная КиевЗНИИЭПом. Она представляла собой унифицированные конструкции для строительства практически в любом регионе страны. Для особых региональных условий севера «Мобиль» имела унифицированный набор строительных изделий, различные варианты блок-секций, решений узлов, варианты цветовой и пластической гаммы панелей.

Однако проведенные расчеты ЛенЗНИИЭПа показали, что решение проблемы развития индустриального домостроения для удаленных районов 


\section{ГОРОДСКОЕ СТРОИТЕЛЬСТВО В ХАНТЫ-МАНСИЙСКОМ АВТОНОМНОМ ОКРУГЕ - ЮГРЕ (к.1950-х - сер.1990-х г2.)}

севера в экономическом и архитектурно-конструктивном отношениях находится в иной плоскости, чем та, которую предлагает система «Мобиль». К тому же выводу пришли ученые в Швеции и Финляндии применительно к своим северным территориям (32).

Не прижилась на севере Среднего Приобья и идея строительства монолитных домов. Зимой 1972 года, во время поездки в Сургут, на совещании с хозяйственными и партийными руководителями в Тюменской области Председатель Совета Министров А.Н. Косыгин поделился своими впечатлениями о поездке во Францию, где ему советовали строить в Сибири малозатратные монолитные, а не крупнопанельные здания. Ш.С. Донгорян вспоминал: «Я ожидал, что все присутствующие министры выступят против этого. Но большинство закивало головами и произнесло да, да, да... И я решил вступить в полемику... Я сказал, что действительно монолитное домостроение выгодно в теплых регионах нашей страны. Но в Западной Сибири, где 7 месяцев зима, при сильном морозе невозможно качественно бетонировать стены и перекрытия. Далее добавил, что монолитные стены и перекрытия перед отделкой надо будет сушить, в зимних условиях даже при больших затратах равномерной сушки невозможно добиться...».

Беседа профессионального строителя завершилась заключением Алексея Николаевича: «Да, пожалуй, Вы правы, монолитнее домостроение в условиях севера нетехнологично и, очевидно, не может быть эффективнее крупнопанельного домостроения». Все присутствующие облегченно вздохнули (33).

На севере Западной Сибири дополнительные сложности сохранения удовлетворительного состояния внешнего вида зданий создавали региональные природно-климатические условия. Вместо обычных красителей и отделочных материалов в Среднем Приобъе необходимо было использовать специальные составы, атмосфероустойчивые в суровых условиях севера. В исследуемый период использование таких эффективных отделочных материалов осуществлялось крайне недостаточно при заводском способе отделки, а на строительных площадках наблюдается их полное отсутствие. Следует, однако, признать, что на Сургутском ДСК предпринимались попытки использовать способы отделки панелей декоративными полимер-цементными пастами и цветными растворами с рельефной поверхностью. А ЛенЗНИИЭПом проводились разработки ряда научных эффективных способов отделки стеновых конструкций. 
Положение стало меняться в 1999 году. Тогда Управление архитектуры и градостроительства в Сургуте предприняло попытку изменить облик города. По его инициативе начались работы по «облагораживанию» не рассчитанных на столь длительную эксплуатацию «хрущевских» пятиэтажек и других сооружений унифицированной архитектуры советского периода сургутского градостроения. Сначала в качестве наружного отделочного материала использовали плитку. Но она была довольно дорогостоящей. Тогда решили использовать краску. Этим стала заниматься научно-техническая мастерская «Канон», которая в 2001 году по итогам выставки завоевала вторую премию за реализацию концепции колористического изменения застройки Сургута. Одним из первых «раскрашенных» зданий стал расположенный на улице Ленина «Детский мир». Его колористика получила различную оценку специалистов и представителей общественности города. Рождался новый образ Сургута. Начав с покраски отдельных домов, в 2002 году мастерская «Канон» уже имела договоры на обновление 30 домов (34). Впоследствии эта работа развернулась в городе повсеместно.

Образ города создавали и ночное освещение, и рекламные щиты, и многое другое, входящее в понятие «среда города». По решению Думы в 1999 году была принята целевая программа «О развитии наружной рекламы на территории Сургута». Ее реализацию взялось выполнить МП «Торгтехника и реклама». Она стала основой дальнейшей работы по осуществлению комплекса мероприятий, включающих в себя установление рекламных щитов европейского стандарта, тумб для информации о социальной и культурной жизни города, стендов для частных объявлений, ночной иллюминации улиц Сургута (35).

Таким образом, в 1970-е гг. в городах ХМАО-Югры градостроительная политика начинает приобретать черты большей управляемости и более уверенного противостояния ведомственной тенденции. Сургутские архитекторы сделали максимум возможного для реализации в кратчайшие сроки в экстремальных условиях севера Западной Сибири крупномасштабных проектов благоустройства, комфортности и безопасной жизнедеятельности жителей нового города. 


\section{Примечания}

1. ГАСПИТО. Ф.124.Оп.19.Д.73.Л.46.

2. ГАСПИТО.Ф.113. Оп.31.Д.7. Л.51.

3. Там же.

4. История и перспективы градостроительного освоения...С. 239.

5. Сургутская трибуна. 1990.12 мая.

6. ГАСПИТО.Ф.Ф.113.Оп.31.Д.7. Л.90.

7. Там же. Л.87.

8. Там же. Л.90.

9. Там же.

10. Там же. Л.90.

11. Сургутсая трибуна.1990.12 мая.

12. История и перспективы градостроительного освоения...С.251.

13. Практика строительств в Западно-Сибирском нефтегазодобывающем районе // История и перспективы градостроительного освоения...С.155-156.

14. Литвинов С.В. Архитектурно-планировочное развитие городов Среднего Приобья (исторический анализ и решения). Автореф. дис. ... канд. арх-ры. - СПб., 2007. - С. 8.

15. История и перспективы градостроительного освоения...С.156.

16. Там же.

17. Вести СТС. 2000.5 февраля. № 6.С.2

18. ВестиСТС.2000. 5 февраля. № 6. С.3.

19. Там же.

20. ГАСПИТО. Ф.124.Оп.191.Д.73. Л.49

21. Там же.

22. Материалы отдела архитектуры администрации города Сургута, 2006. Л.7, 8, 13, 16.

23. Новый город. 2003.9 августа

24. ГАСПИТО. Ф.113. Оп.31. Д.7. Л.89.

25. ГАСПИТО.Ф.124. Оп.191.Д.73. Л.90.

26. ГАСПИТО.Ф.124.Оп.191.Д.73.Л.12

27. Тамже. Л.90.

28. Там же. Л.140.

29. Донгарян Ш.С. Указ.соч. С.191.

30. Донгорян Ш.С. Нефть и Щербина. // Соратники: поколение Виктора Муравленко. Тюмень, 2002. С.154. 
31. Особенности градостроительства в нефтедобывающих районах. Л., 1970. C.67.

32. Донгорян Ш.С. Указ. соч. С.155.

33. ДонгорянШ.С.Указ. соч.С.192

34. Особенности градостроительного освоения...С.15

35. Югра.2002.21-28 февраля 


\section{ГЛАВА 3. \\ РАЗВИТИЕ МЕСТНОГО ПРОИЗВОДСТВА СТРОИТЕЛЬНЫХ МАТЕРИАЛОВ}

К моменту сенсационных открытий месторождений углеводородного сырья на рубеже 1950-х-1960-х гг. промышленность строительных материалов $\mathrm{XMAO,} \mathrm{как} \mathrm{и} \mathrm{Тюменской} \mathrm{области} \mathrm{в} \mathrm{целом,} \mathrm{была} \mathrm{представлена} \mathrm{несколькими}$ мелкими, порой полукустарными предприятиями, производящими преимущественно кирпич и незначительное количество черепицы, силиката и некоторых других компонентов строительного производства. В области складывалось крайне тяжёлое положение с обеспечением строек: имелось 79 кирпичных заводов, но только 2 из них являлись заводами круглогодичного действия. Без них 77 мелких кустарных заводов в 1959 году произвели 60 млн. штук кирпича, т.е. по 770 тыс. штук за сезон на один завод (1).

Многие предприятия области из года в год не выполняли плановых заданий производства кирпича. В 1959 году годовой объём его выполнения составил 60\%. Кирпичные заводы недодали более 70 млн. штук условного кирпича (2).

В 1948-1956 гг. существовал Тюменский черепичный завод. Он производил черепицу и гончарную посуду (3). В 1961-1962 гг. в Тюменской области действовал небольшой силикатный завод (4). В силу неэффективной работы они были ликвидированы: черепичный завод - в 1956 году на основании приказа Министерства промышленности стройматериалов РСФСР от 22.06.1956 г. № 214, а силикатный - в 1962 году (5). Тюменский завод «Строитель», переданный от Свердловской железной дороги Тюменскому областному управлению стройматериалов, был ликвидирован в 1955 году (6).

Кирпичные заводы носили преимущественно сезонный характер и были оснащены устаревшим оборудованием с небольшой производительностью труда, на них использовались отсталые технологии. Обжиг основной части кирпича осуществлялся в напольных печах, где топливом являлись дрова. Из-за их плохого качества перерасход топлива против нормы на 1 тыс. штук кирпича составлял $1 \mathrm{~m}^{3}$ древесины.

Кольцевые же печи давали большой перерасход каменного угля и значительную часть времени простаивали из-за недостаточного количества его поставок и низкого качества (7). Для них было характерно несоответствие основных производственных мощностей. Если обжиг кирпича позволял 
производить до 30 млн. штук условного кирпича в год, то сушка была рассчитана только на 18 млн. шт. (8).

Среди многочисленных ведомственных полукустарных производств кирпича в 1965 году в Тюменской области наиболее предпочтительно выглядели 5 его производителей: Тюменский завод «Труд», насчитывавший в январе 1965 года 266 работников, Тюменский завод № 1 с 249 работающими, Ишимский кирпичный завод, насчитывавший в своем штате 63 человека, Тобольский кирпичный завод, на котором трудилось 34 человека, и Тюменский завод силикатных изделий, обеспечивавший работой 76 человек. Они входили в состав областного Управления промышленности строительных материалов, возглавляемого В.М. Хабаровым (9).

Как видим, они не поражали своей численностью. Самым большим и стабильно работающим производственным коллективом в то время являлся Тюменский кирпичный завод «Труд», расположенный в поселке Богандинский. О конкретной дате его рождения точных сведений пока обнаружить не удалось. Но достоверно известно то, что он был национализирован в 1917 году (8), а первые упоминания о нем, относящиеся к советскому периоду, содержат ведомости о выплате заработной платы, датированные 1931 годом. Они хранятся в архиве администрации Тюменской области (10).

Еще с 1950-х гг. в структуру кирпичного завода «Труд» входили глиняный и песчано-гравийный карьеры, а также формовочный, черепичный, электроцех и механический цех, цех сушки, обжига, строительства и снабжения, МОП, ЖКО, гараж, четыре участка, включая гипсовый. Завод успешно справлялся с плановыми заданиями, обеспечивая потребности местной промышленности в удовлетворительной по качеству кирпичной и иной продукцией (11).

Но этого оказалось крайне недостаточно к середине 1960-х гг. В 1966 году в связи с ускоренным развитием нефтегазового освоения территории севера Западной Сибири и бурным ростом промышленного и гражданского строительства дефицит кирпича в Тюменской области составил 504 млн. штук. Важнейшие стратегические объекты промышленного и гражданского строительства нового крупнейшего в стране нефтегазоносного региона не обеспечивались в полной мере стеновыми материалами и особенно кирпичом.

Обеспокоенные создавшимся положением в производстве кирпича, партийные, советские хозяйственные органы предпринимают решительные меры по ликвидации дефицита стеновых материалов в Западной Сибири. 
В середине 1960-х гг. Тюменским обкомом КПСС совместно с советскими хозяйственными органами была утверждена крупномасштабная программа развертывания в области производства строительных материалов и конструкций, которая предусматривала создание 14 заводов с объемом выпуска 250 млн. штук кирпича в год (12).

Наряду со строительством новых заводов по производству кирпича большую роль в обеспечении строительных организаций стеновыми материалами призваны были сыграть реконструируемые предприятия. Масштабы реконструкции действующих кирпичных заводов охватывали 10 предприятий с предполагаемым объемом производства 80 млн. штук кирпича в год (13).

В ходе выполнения решений Тюменского обкома КПСС областной исполнительный комитет депутатов трудящихся обратился в Министерство строительства РСФСР с просьбой обязать институт «Гипростроя» подготовить к 1 августа 1966 года сметную документацию на строительство и реконструкцию кирпичных заводов: в Тюмени - с объемом производства в 40 млн. шт. условного красного кирпича, в Ишиме - 40 млн. шт. условного кирпича, в Тобольске - 60 млн. штук условного кирпича в год. Облисполком запросил у министерства промышленного строительства 2 млн. рублей и немедленно приступил к выполнению программы строительства заводов стеновых материалов с расчетом покрытия образовавшегося в области дефицита кирпича путем последовательного ввода в эксплуатацию мощностей предприятий с объемом производства в 1966 году - 35 млн. шт. условного кирпича, в 1967 году - 80 млн. шт. условного кирпича, в 1968 году - 90 млн.шт. условного кирпича, а в 1969 году - 100 млн. штук условного кирпича в год (14).

Выполнение принятой программы создания и реконструкции предприятий строительной индустрии в новой нефтегазовой провинции было связано с большими трудностями. Областное управление промышленности стройматериалов планировало осуществить расширение и реконструкцию существующих заводов к 1967 году и за счет этого увеличить их мощность на 57 млн.шт. кирпича в год. Однако из-за отсутствия в области подрядных строительных организаций освоить необходимые объемы строительномонтажных работ не представлялось возможным. В 1966 году при Тюменском областном управлении производства строительных материалов был организован ремонтно-строительный участок, и за пять месяцев его работы удалось освоить 300 тыс. рублей. Но это не могло удовлетворить потребности 
начатого крупномасштабного строительства заводов стеновых материалов в главном нефтедобывающем регионе страны. Необходимо было изыскать новые подходы к реконструкции кирпичных заводов. Тюменский облисполком выступил с инициативой реорганизовать этот ремонтно-строительный участок и создать ремонтно-строительные управления в Ишиме, Тобольске и Тюмени с расчетом освоения в области 1 млн. 96 тыс. рублей в 1967 году (15).

Однако для выполнения такой задачи промышленные предприятия строительной индустрии Тюменской области нуждались в значительном техническом обновлении. Заводы областного управления испытывали острую неудовлетворенную потребность в землеройных машинах и производственных механизмах. Начальник Тюменского областного управления промышленности строительных материалов в обращении в облисполком сообщал о том, что для выполнения плана мероприятий по расширению мощностей производства кирпичных изделий заводоуправлению требуется 5 автомобилей ГАЗ-51, 5 тракторов ДТ-75, 5 самосвалов ЗИЛ-130, 3 бульдозера ДТ-75, 2 бульдозера ДТ-100, 2 бульдозерных установки на базе трактора ДТ-75, 2 автокрана ЛАЗ-690, 3 экскаватора Э-153, экскаватор Э-652, 3 сварочных аппарата, 3 бетономешалки объёмом 250 литров, 3 растворомешалки, башенный кран, легковой автомобиль «Москвич» (16).

Особое беспокойство у руководства управления вызывало отсутствие новых механизмов ключевых предприятий создаваемой индустрии производства стеновых материалов. Тюменскому кирпичному заводу для развертывания в 1966 году запланированного производства в силу износа старой техники не хватало экскаватора ёмкостью котла 0,93 куб.м. и бульдозера мощностью 140 л.с. В таких же машинах нуждался Тюменский завод «Труд», Ишимский и Тобольский кирпичные заводы. Всего по управлению промышленности строительных материалов в 1966 году не хватало 8 бульдозеров и 6 экскаваторов (17).

Особенно остро вопрос расширения и обновления производственных мощностей стоял перед руководителями Тюменского силикатного завода в силу того, что он в 1965 году был сдан с большими недоделками. На заводе необходимо было осуществить полную перестройку производства на новый технологический поток для того, чтобы добиться снижения его себестоимости и повышения рентабельности (18).

Обновление и эксплуатация материальной базы производства кирпичной продукции проходили в условиях отсутствия соответствующего 
технологического и вспомогательного оборудования ремонтной базы. Так, например, на силикатном заводе балансовая стоимость установленного оборудования составляла в 1966 году 820 тыс. руб. Однако ремонтная база была снабжена только одним токарным и двумя сверлильными станками.

Недостаток ремонтного оборудования приводил к нарушению ритмичности работы предприятий, когда основной выпуск продукции приходился на третью декаду месяца в силу того, что ремонт технологического оборудования из-за специфики производства строительных материалов проводился главным образом в это время.

Подобное состояние ремонтной базы в условиях наладки и замены отдельных видов устаревшего оборудования, а также полного отсутствия централизованной поставки запчастей обусловило недовыполнение плана выпуска кирпича. В 1966 году оно составило 6,1\% (19).

Невыполнение плановых заданий сопровождалось также медленным вводом в строй сырьевых карьеров производства строительных материалов. План монтажных работ за 8 месяцев 1966 года по строительству предприятий нерудных материалов, осуществляемый Министерством строительства РСФСР, в 1966 году был выполнен только на 75\%. Из 13 территориальных главных управлений, осуществлявших подобного рода строительство, ни один план не выполнен (20).

С еще большим отставанием, на 70\%, велось строительство пусковых карьеров. В их числе был и ведущий поставщик нерудных материалов Тюменского областного управления - Перевалочный карьер. Положение усугублялось тем, что для эксплуатации его уже обустроенных к тому времени площадей не хватало двух бульдозеров и экскаватора мощностью 1,3 куб.м. (21).

Очень сложная производственная обстановка складывалась на Воронинском месторождении глины. Здесь основные запасы к 1966 году были исчерпаны. Оставшиеся же пласты был не пригодны для производства качественного кирпича вследствие наличия в них пылевидных и известковых включений. Кирпич, произведенный из этого сырья, по товарному виду и особенно по механическим свойствам соответствовал низкой 75-ой марке и не отвечал более высоким требованиям ГОСТА, предъявляемым в отношении 100-ой, 125-ой и 150-ой марок кирпича.

Вследствие этого предприятия стеновых материалов Тюменской области несли большие финансовые потери. Так, например, на заводе силикатных изделий из-за низкой марочности кирпича удорожание его себестоимости в год 
составляло 80-100 тыс. руб. Проблема состояла в организации по опыту керамзитового завода дополнительного извлечения и доставки ежесуточно 500 тонн качественной глины, пригодной для строительства домов любой этажности из находящегося на расстояние 55 км от силикатного завода Богандинского месторождения (22).

Отсутствие собственного автомобильного парка являлось причиной и других больших производственных потерь на новых и реконструируемых предприятиях Тюменской области. В течение многих лет они были вынуждены арендовать грузовые и пассажирские машины у Министерства автомобильного транспорта РСФСР. Это создавало большие трудности как для транспортировки сырья и товарной продукции, так и для перевозки рабочих и служащих заводов стеновых материалов, проживающих на значительном расстоянии от места работы. В 1965 году предприятия Тюменского областного управления промышленности строительных материалов из-за систематических опозданий обслуживающих их автобусов потеряли 758 часов рабочего времени, в результате чего заводы недополучили 3375 тыс. штук условного кирпича (23).

Серьезной проблемой в создании условий роста масштабов производства новой отрасли промышленности Западной Сибири являлось то, что занятые в ней работники предприятий Тюменского объединенного управления промышленности строительных материалов имели меньшую материальную мотивацию для производительного труда, т.к., в отличие от тружеников многочисленных ведомственных кирпичных заводов, расположенных на территории области, кирпичные заводы областного управления промышленности строительных материалов не входили в перечень предприятий, труженикам которых выплачивался районный коэффициент 0,15 (24). На пяти таких предприятиях трудилось 1087 работников со среднемесячной заработной платой всего в размере 99 рублей (25).

Рабочие кирпичных заводов областного управления и их родственники проживали в тяжелых бытовых условиях. Они испытывали острую нужду в благоустроенном жилье. Например, рабочие и члены семей Тюменского кирпичного завода «Труд» в количестве 126 человек при численности его персонала более 260 человек проживали в неприспособленных деревянных строениях барачного типа с печным отоплением и без канализации. Эти находящиеся в аварийном состоянии помещения были построены еще в 1943 1955-х гг. и требовали капитального ремонта, замены перекрытий и кровли, 
промерзающих половых настилов, прогнивших углов и нижних венцов бревенчатых стен, а по большому счету полного сноса (26).

Неслучайно поэтому на кирпичных заводах, где использовался тяжелый физический труд, наблюдался высокий уровень травматизма и несчастных случаев. Отсутствие благоприятных условий повседневного полноценного семейного отдыха в нерабочее время, здорового бытового досуга затрудняло восстановление затраченных физических сил работников задымленных и загазованных цехов «горячего» кирпичного производства.

Администрация заводов выделяла немалые средства на оборудование и ремонт вентиляционных систем и мероприятия, направленные на совершенствование техники безопасности. Их объемы представлены в таблице № 1 (27).

Таблица № 1

Освоение средств, направленных на проведение мероприятий по улучшению техники безопасности рабочих Тюменского областного управления промышленности строительных материалов в 1966 году

\begin{tabular}{|l|c|c|c|c|c|c|}
\hline Наим.предп. & Всего & На техн безопасн. & На вентил. & Сан.быт. & Всего & На тех.б. \\
\hline Силикат. з-д & 12000 & 5700 & 1300 & 5000 & 12300 & 6100 \\
\hline Кирпич.з-д«Труд» & 8000 & 4000 & 1200 & 2800 & 7500 & 3000 \\
\hline Кирпич. 3-д№ 1 & 19300 & 4000 & 8000 & 7300 & 17200 & 3900 \\
\hline Ишим. 3-д & 1850 & 830 & 180 & 840 & 2400 & 400 \\
\hline Тобол. 3-д & 1850 & 883 & 147 & 821 & 1500 & 800 \\
\hline Всего & 43000 & 15360 & 10827 & 16761 & & \\
\hline
\end{tabular}

Данные таблицы свидетельствуют о том, что администрация предприятий кирпичного производства Тюменского областного управления стеновых материалов уделяла санитарному и бытовому обустройству цехов предприятий достаточно пристальное внимание. Вместе с расходами на ремонт вентиляции эта статья была ведущей и составила больше половины, 27588 руб. из общей суммы 43000 руб., затрат на охрану труда. Это было вызвано тем, что, в отличие от машиностроительного и других производств, где особое беспокойство вызывало состояние «технической безопасности», кирпичные заводы отличались крайне неблагоприятной экологической обстановкой, поэтому здесь главная причина травматизма и несчастных случаев была связана не с нарушениями техники безопасности, а с вредными для здоровья участников «горячего производства» условиями труда. 
Особую заботу о рабочих предприятия, как следует из таблицы, проявлял Тюменский кирпичный завод № 1, на долю которого приходилась почти половина выделенных управлением средств на эти социальные потребности. В 1967 году на предприятии была установлена дополнительная вентиляция и орошение на запыленных участках, усилена герметизация и уплотнение дверей транспортных устройств. С рабочими были проведены занятия, и они были ознакомлены со специфическими правилами безопасной работы на всех участках кирпичного производства.

На охрану труда в 1967 году было израсходовано 1474 руб. и приобретено спецодежды на сумму 4809 руб., спецмыла - 2591 руб. спецжиров - 2841 руб. Администрацией завода совместно с профсоюзной организацией был разработан план мероприятий по охране труда, технической безопасности и промсанитарии. Об их выполнении и нерешенных проблемах руководители цехов еженедельно отчитывалась на производственных совещаниях и планерках (27).

Только в первом полугодии 1967 года на осуществление мероприятий по улучшению охраны труда предприятиям Тюменского областного управлении промстройматериалов было выделено 8035 руб. Из них на социально-бытовое устройство зон отдыха в производственных цехах было направлено 3570 руб. (28), на ремонт вентиляционных систем было ассигновано 3400 рублей, затраты на проведение мероприятий по улучшению техники безопасности составили 1065 руб. (29).

Однако уровень травматизма и несчастных случаев на кирпичных заводах Тюменской области оставался высоким, о чем свидетельствует таблица № 2 (30).

Таблица № 2

Производственный травматизм на предприятиях Тюменского Областного управления промышленности стройматериалов в 1966 году

\begin{tabular}{|l|c|c|c|c|c|c|}
\hline \multicolumn{1}{|c|}{ Наим.предп. } & Спис.с. & $\begin{array}{c}\text { Число н.с. } \\
\text { до 3-х д. }\end{array}$ & $\begin{array}{c}\text { Н.С. свыше } \\
\text { 3-х дн. }\end{array}$ & Потери. ч/дн & К/Ч & К.Т. \\
\hline Силикат. 3-д & 354 & - & 5 & 174 & 14,1 & 34,9 \\
\hline Кирпич. 3-д «Труд» & 303 & $1 / 3$ & 21 & 480 & 59,0 & 22,8 \\
\hline Кирпич. 3-д№ 1 & 221 & $1 / 3$ & 7 & 135 & 31,6 & 19,3 \\
\hline Ишим. 3-д & 96 & - & 1 & 68 & 10,4 & 8,0 \\
\hline Тобол. 3-д & 55 & - & 4 & 105 & 73,0 & 21 \\
\hline
\end{tabular}


Данные таблицы утверждают, что наиболее благоприятная травматическая обстановка наблюдалась на самом крупном предприятии производства стеновых панелей - Тюменском силикатном заводе. Здесь при численности работников в количестве 354 человек трудопотери составили всего 174 ч/дней, в то время как на самом небольшом в управлении Тобольском кирпичном заводе со штатом 55 рабочих, т.е., в семь раз меньшим, чем на силикатном заводе, невыход на работу составил почти равное количество с ним- 105 ч/дней.

Наряду с Тобольским кирпичным заводом высокий коэффициент частоты травматизма был характерен для основных поставщиков кирпича в Тюменской области - Кирпичного завода №1 и кирпичного завода «Труд», отличавшимися сходными травмоопасными характеристиками производства обжигового кирпича в «горячих цехах».

На кирпичном заводе № 1, в силу большой утомляемости работников и связанным с ней низким уровнем производственной и технологической дисциплины, несоблюдением работающими правил технической эксплуатации оборудования, а также отсутствием средств механизации тяжёлых физических работ и сигнализации, при штате рабочих в количестве 221 человек в 1966 году произошло 7 несчастных случаев $\mathrm{c}$ коэффициентом тяжести 8,7 и коэффициентом их частоты 3,0 .

Всего на предприятиях областного управления промышленности строительных материалов в 1966 году при среднесписочном составе 1126 чеовек, несмотря на освоение средств, направленных на предотвращение несчастных случаев и травматизма в сумме 43000 рублей, произошло 358 несчастных случаев и событий, связанных с получением травм, вследствие которых было потеряно 966 (по другим источникам 962 ч/дней) (30).

В 1967 году производственная ситуация на кирпичных заводах оставалась весьма травмоопасной. На небольшом Ишимском кирпичном заводе, например, насчитывавшем всего 90 человек, произошло 22 несчастных случая, на заводе «Труд» в 1967 году при списочном составе в 275 человек произошло 19 несчастных случаев (31). В большей степени страдали выгрузчики туннельных печей. В структуре травм рабочих предприятий строительного производства доминировали ушибы, ожоги и переломы конечностей (32), а также имели случаи исхода «И-3», т.е. смертельного исхода (33).

Основные причины травматизма были связаны с организацией производства. Они сложились вследствие отсутствия проектов производимых 
работ, технологических карт монтажа конструкций, графиков выполнения работ, мероприятий, обеспечивающих безопасные и здоровые условия труда, отсутствия достаточного освещения рабочих мест, отсутствия или недостаточного технического надзора за соблюдением рабочими правил эксплуатации оборудования. В силу специфики кирпичного производства наибольшие риски травматизма имели место на операциях, связанных с пылевыделением, отсутствием вытяжной вентиляции, подготовкой извести и ее транспортировкой, а также наибольшей трудоемкостью: укладкой сырца, нагрузкой автоклавов, разгрузкой и погрузкой топлива и сырья на складах. В 1967 году на предприятиях Тюменского областного управления промышленности строительных материалов по этим причинам пострадало 23 человека, из которых 18 эксцессов травматизма произошло по вине администрации (34).

В этой группе причины, приведшие к травматизму 5 человек, были связаны с низкой производственной дисциплиной и случившимися на почве пьянства лихачествами и драками (35). Чуть меньшее количество травм, 18, произошло вследствие технических причин. Среди них из-за конструктивных недостатков в проектах устройства лесов и подмостков, их неправильной установки, бракованных частей и деталей строительных механизмов и устройств, приборов и аппаратов травмировалось 3 человека, отсутствия ограждений на участках опасной работы -6 человек, отсутствия сигнализации - 4 человека (36).

Наиболее травмоёмкими профессиями являлись формовщики и экскаваторщики, получившие соответственно 8 травм и 4. Вследствие отсутствия опыта работы большинство несчастных случаев происходили с молодыми людьми, имевшими производственный стаж менее одного года - 21 человек. Затем в этой печальной шкале значились рабочие со стажем до трех лет - 11 человек. Число травм рабочих с трудовым опытом свыше пяти лет было значительно меньше - 3 человека (37).

Тем не менее производственные мощности выпуска стеновых материалов последовательно расширялись, а объемы их производства заметно росли. Большое значение в деле повышения эффективности использования рабочего времени и роста производительности труда имели общественные смотрыконкурсы рационализаторов и изобретателей, проводимые в целях повышения рентабельности и культуры труда. Заметную роль в активизации этой работы на 
предприятия строительной промышленности Тюменского областного Управлении сыграл смотр-конкурс, проведённый 20 мая 1967 года (38).

Тюменским областным управлением в августе 1966 года было начато монтирование строительно-ремонтного участка и освоено к концу года 490 тыс. рублей. Организация строительного участка позволила завершить строительство и монтаж оборудования цеха № 2 Тюменского кирпичного завода № 1 с мощностью производства 8 млн. штук кирпича в год. Одновременно решался вопрос о формировании на базе этого участка более крупного предприятия с объемом освоения строительно-монтажных работ в размере 857 тыс. руб. в 1967 году. Кроме этого, в том же году было завершено строительство новых производственных площадей на Ишимском и Тобольском кирпичных заводах и освоение питающего их Бабарыкского карьера (39).

На первом участке Тюменского кирпичного заводе № 1 было завершено строительство и обустройство зоны для содержания спецконтингента, и 4 ноября 1966 года она была заселена. В январе 1967 года завершена реконструкция второго участка с переводом его на круглогодичное производство и доведением мощности до 8 млн. штук условного кирпича (40).

Высокими темпами шла реконструкция ветерана кирпичного производства Тюменской области завода «Труд». Инженерно-техническому персоналу этого предприятия удалось расширить кольцевую печь на четыре камеры на участке № 3 «Бабарынка». После этого удалось добиться увеличения объема обжигового кирпича до 500 куб. метров. На технологической линии этого участка вследствие его перехода на круглогодичное производство выход кирпича составил 14 млн. штук (41).

Ведущим специалистам завода на технологической линии участка № 1 удалось установить вальцы грубого помола СМ-150, а для добавки отощителя в жирную глину было установлено сито-буран. При укладке кирпича-сырца на сушильные вагонетки был механизирован труд формовщиц, а для увеличения производительности труда выгрузчиц готового кирпича были внесены изменения в работу люлечного конвейера (42).

Реконструкция старых заводов и строительство новых, сопровождавшиеся апробацией новой техники, ее монтированием, заменой устаревшего оборудования являлись характерными чертами производства в то время. Тяжелые условия труда на производстве кирпича, низкая заработная плата, по сравнению с работниками других ведомств, острый дефицит жилья и целый ряд других причин повседневной жизни порождали глубокое 
недовольство рабочих условиями труда и быта, создавали основу большой текучести кадров, которая была гораздо выше, чем на предприятиях других отраслей промышленности (43).

Из поступивших в 1966 году на заводы областного управления промышленности стройматериалов 1015 человек уволилось 1005 работников. В 1967 году поступило на кирпичные предприятия 697 человек, а оставило их 625 человек. За 9 месяцев 1968 года было принято на работу 614 человек, а уволилось 625 человек. Для сравнения отметим, что в общем штате управления со всеми подразделениями текучесть кадров была большой, но гораздо меньшей, по сравнению с текучестью работников основных цехов. Соотношение составляло приблизительно 50\% к 100\% (44). В 1966 году на Тюменском заводе силикатных изделий для обеспечения работы технологической линии требовалось 355 рабочих. А фактически работало 232 человека (45). В 1967 году кадровая ситуация на нем не изменилась. Дефицит рабочих составлял 168 человек (46).

Проведенный в 1967 году расчет потребности предприятий в инженернотехнических специалистах высшей квалификации при существующих темпах расширения объемов кирпичного производства и сохранения масштабов его текучести свидетельствует о том, что если в 1967 году она составляла 6 штатных единиц, то в 1968 году должна возрасти до 7, в 1969 году - до 10, а в 1970 году-до 15 человек (47). В 1977 году после перехода в стране к обязательному среднему образованию и реформе системы профессиональнотехнического образования количество работников со средним техническим образованием стало увеличиваться. Их число на Тюменском заводе строительных материалов составило 14 человек, а на кирпичном заводе «Труд» - 6 человек.

Однако текучесть рабочих кадров не сокращалась. В 1971-1974 гг., например, на кирпичном завод «Труд» число уволенных рабочих даже превышало количество принятых: поступило 1311 человек, а уволилось 1330 человек (48).

Потребность в рабочих кадрах оставалась исключительно высокой и покрывалась в основном за счет привлечения на производство лиц с криминальным прошлым. На Тюменском заводе строительных материалов в 1976 году из общей численности рабочих в количестве 379 человек 316 человек относились к категории трудящихся, именуемой «спецконтингент». На кирпичном заводе «Труд» из 243 работающих его представителями являлись 
163 человека, вольнонаемных рабочих на этих заводах было соответственно всего 25 и 80 человек (49).

В исследуемый период все предприятия Тюменского областного управления промышленности строительных материалов удовлетворяли свои кадровые потребности в основном за счет Управления исправительно-трудовых лагерей. Эта мощнейшая организация стала монопольным поставщиком рабочих кадров производства кирпичной продукции. Положение усугублялась тем, что другой источник рабочей силы в лице вольнонаемных тружеников до $40 \%$ включал в себя лиц, приглашенных из других отраслей народохозяйственного комплекса Тюменской области и поэтому не имевших необходимую квалификацию. Очень низкая квалификация основной массы контингента рабочих предприятий, сформированная из представителей «спецконтингента» и требовавшая смены квалификации вольнонаемных тружеников, а также направляемых на «перевоспитание» подростков с криминальным прошлым и пониженным уровнем социальной ответственности в условиях высокой текучести кадров предъявляли особые требования к их профессиональному обучению.

Система подготовки рабочих на производстве складывалась и совершенствовалась параллельно с решением вопросов реконструкции и ввода в строй новый предприятий. На начальном этапе их развития учебные классы отсутствовали. Обучение осуществлялось в строительных конторах, красных уголках, столовых, общежитиях и иных неприспособленных помещениях без достаточной учебно-материальной базы.

Качество обучения зависело от кадрового состава преподавателей и инструкторов. Однако в рассматриваемый период предприятия севера Западной Сибири испытывали хроническую потребность в мастерах высшей квалификации производства стеновых материалов. На Тюменском кирпичном заводе «Труд», например, в штате его сотрудников числилось всего несколько человек с высшим и средним техническим образованием. Предложения Тюменского управления промышленности строительных материалов об организации учебного комбината поддержки министерства не получали (50).

Тем не менее в 1965 году непосредственно на предприятиях Тюменского управления было подготовлено 152 рабочих. Осуществлялась форма индивидуального и бригадного обучения. Доминировало бригадное обучение. В этой форме было подготовлено 123 человека. На Тюменском силикатном 
заводе из числа 35 обученных 31 человек получил новую профессию путем бригадного обучения (51).

Такое преимущество этой формы обучения было обусловлено тем, что, во-первых, в середине 1960-х гг. большими темпами шло расширение производственных площадей, требовавшее увеличения контингента рабочих путем их массового охвата обучением. Во-вторых, это было связано с высоким оборотом сменяемости рабочих, обусловленного высокой текучестью кадров. В-третьих, специфика главного источника поступления рабочих на производство диктовала необходимость их постоянной переподготовки в связи со сменой профессий.

В ней нуждались не только вновь принятые рабочие, но и работники, имевшие продолжительный трудовой стаж, в связи с осуществляемой реконструкцией и модернизацией устаревшего оборудования. Необходимость постоянного повышения квалификации рабочего определялась изменениями технического уровня и усложнением технологии производства, требующего постоянного совершенствования профессиональных знаний, умений и навыков. Система повышения квалификации включала в себя профессиональное обучение рабочих, направленное на рост квалификационного разряда по имеющейся профессии и позволяющее ему выполнять функции более сложного труда и управлять более современной производительной техникой.

Как мы отмечали, обновление демонтированных основных технологических линий было осуществлено на Тюменском кирпичном заводе «Труд» и Тюменском кирпичном заводе № 1. На введенном в строй Тюменском силикатном заводе было установлено современное оборудование. На всех кирпичных заводах области была осуществлена замена наиболее важных агрегатов производства кирпича. В то же время на Тюменском кирпичном заводе «Труд», например, в 1967 году из 251 человек персонала, включенного в основной производственный цикл, 177 человек имели возраст от 25 до 44 лет и нуждались в профессиональном совершенствовании (52).

В 1970-е годы продолжающаяся комплексная механизация производственных процессов и новая технология, несмотря на eе непоследовательное внедрение, оказывали двоякое воздействие на профессиональное формирование работников и уровень их технической подготовки. Обслуживание новой техники требовало от рабочего более высокого мастерства и опыта. Большая надежность работы современного оборудования наряду с выполнением рабочими все более узких функций при 
усложняющихся технологических процессах вела к тому, что число профессий и специальностей увеличивалось, а круг необходимых для них знаний сужался. Поэтому преодоление узкой специализации, борьба со снижением уровня профессиональной подготовки становились все более важной задачей отделов технического обучения предприятий производства стеновых материалов.

Решая ее, администрация и общественные организации кирпичных заводов разъясняли трудящимся важность овладения вторыми и смежными специальностями, поддерживали начинания рабочих в этом направлении, помогали создавать необходимые условия, развивали такие передовые формы организации труда, как многоагрегатное обслуживание, совмещение профессий и трудовых функций. Необходимость этой работы актуализировалась тем, что на предприятиях стеновых материалов севера Западной Сибири во второй половине 1960-х гг. имел место массовый переход производства кирпича от дровяных напольных печей к работающим на каменном угле кольцевым печам без принятия соответствующих мер по их кадровому обеспечению.

В связи с этим во второй половине 1960-х гг. в трудовых коллективах предприятий Западной Сибири была развернута активная работа по увеличению зоны обслуживания технологических линий производства кирпича, освоению вторых и смежных профессий. В силу специфики технологической эволюции производства кирпича, эта форма повышения становилась ведущей на предприятиях Тюменской области. В 1967 году на Тюменском кирпичном заводе № 1 из прошедших обучение 48 рабочих 25 повысили квалификацию в порядке обучения вторым профессиям (53).

Важнейшим средством стимулирования технического роста рабочих кирпичного производства являлось в исследуемый период повышение разряда и перевод на более квалифицированную работу, присвоение почетных званий «Ударник коммунистического труда», «Ударник пятилетки», «Лучший по профессии», «Специалист высокой квалификации», установления доплаты за расширение зоны обслуживания и совмещение профессий, предоставление отпусков в летнее время, путевок в дома отдыха. Заработная плата прошедших такое обучение работников заметно превышала заработную плату своих коллег.

В результате пристального внимания администрации к развитию этого движения количество совмещающих профессию в 1970-е гг. заметно увеличилось. На Тюменском силикатном заводе в 1975 году 15 человек работало по методу совмещения. Они обслуживали 12 \% оборудования (54). 
Важное место в научно-технической и производственной пропаганде повсеместно на всех предприятиях индустрии Западной Сибири занимали научно-техническое общество (НТО) и Всесоюзное общество изобретателей и рационализаторов (ВОИР). В эти годы принимались меры по совершенствованию организационных форм и методов стимулирования участия рабочих в движении рационализаторов и изобретателей. Существенно расширился состав участников движения рационализаторов и изобретателей в ходе проведения Всесоюзного смотра научно-технического творчества молодежи «Пятилетке-упорный труд, мастерство и поиск молодых!». В первой половине 1970-х гг. оно приобрело массовый характер.

Администрация предприятий промышленности строительных материалов проявляла большую заинтересованность в участии рабочих руководимых ею кирпичных заводов в этом движении, осознавая его роль не только в повышении их культурно-технического уровня и квалификации, но также и в нравственном развитии рабочих. Администрация и общественные организации предприятий промышленности строительных материалов поддерживали творческую энергию трудящихся. В этих целях периодически проводились смотры-конкурсы рационализаторов и изобретателей «За высокую культуру труда» (55).

В ходе их проведения был накоплен интересный опыт. Например, на Тюменском заводе «Труд» функционировали школы рационализаторов и изобретателей, где передовые рабочие знакомили трудовые коллективы со своими предложениями по совершенствованию технологии и техники кирпичного производства (56). Это было особенно необходимо, потому что форсированное техническое перевооружение кирпичных заводов сопровождалось их преждевременными поломками, быстрым износом, простоями и потерей рабочего времени. В июне 1966 года на Тюменском заводе силикатных изделий из-за поломки пальцев транспортера, износа пластин пресса, поломки экскаватора, выхода из строя вентилятора, прекращения подачи пара, поломки элеватора и смесителя, пальцев на смесителе, порыва транспортной ленты, отсутствия запасных частей для проведения планового капитального ремонта формовочных проточных прессов СМ - 816 простои оборудования составили 30 часов (57).

На Тюменском кирпичном заводе № 1 в течение 4 месяцев 1968 года простаивала обжиговая печь из-за отсутствия обжиговых заготовок. Указания Министерства промстройматериалов РСФСР и Главного областного 
управления промышленности стройматериалов поставщику, Ливенскому заводу, на отгрузку обжиговых заготовок не выполнялась (58).

Участок № 1 Тюменского кирпичного завода № 1, находившийся на территории в черте города, подлежащий сносу из-за отсутствия технологического транспорта и изношенности оборудования, стабильно работал в режиме перманентных простоев и систематически не выполнял плановые задания. На заводе в течение 4 месяцев было совершенно прекращено производство шлаковых блоков и гипсовых плит из-за отсутствия цемента и гипсового камня, поставляемого Кунгурским строительным комбинатом. Не на полную мощность до 1969 года работало оборудование Тобольского и Ишимского кирпичных заводов вследствие осуществляемой на их площадях тотальной технологической реконструкции (59).

В результате простоев механизмов кирпичных заводов снижалась их сменная выработка. Например, на заводе силикатных изделий в 1966 году на один пресс она составила 12,5 тыс. штук кирпича в смену вместо установленных 20 тыс. штук. Росли расходы предприятий на обслуживание простаиваемого оборудования, составившие в 1966 году на заводе «Труд», например, 0,9 тыс. рублей (60). По плану того года себестоимость одной тысячи штук кирпича должна была составить 37 руб. 25 коп., а фактически затрачивали на ее производство 40 руб. 30 коп. (61).

Допущенные простои существенно влияли на размер заработной платы рабочих кирпичных заводов. В 1966 году она составляла в среднем 2,2 тыс. рублей. При этом оплата основным акторам кирпичного производства, «жигарям», из-за простоев снижалась до 0,6 тыс. рублей. При переводе их во время простоев на дополнительные работы по очистке сараев от мусора и битого кирпича оплата составляла 0,7 тыс. рублей. В зимнее время оплата подвоза дров к напольным печам, а также дробление угля для кольцевых печей осуществлялась в размере 0,5 тыс. рублей. В 1966 году на заводе «Труд» было допущено 18 случаев перерасхода заработной платы на общую сумму 26,0 тыс. руб. (62).

Органической частью технологического процесса производства строительных материалов являлось обеспечение их сырьем. В 1966 году потребность Тюменского кирпичного завода № 1 в глине составляла 65762 куб.м. в год, кирпичному заводу «Труд» необходимо было 42500 куб.м, потребности Ишимского кирпичного завода составляли 15000 куб.м., а Тобольского кирпичного завода - 6250 куб.м. (63). 
Для обеспечения кирпичных заводов Тюменской области строительным песком в 1966 году было завезено из Омской, Свердловской и Челябинской областей около 200 тыс. куб.м. этого необходимого сырья. При существующем состоянии его добычи в Тюменской области по подсчетам экономистов к 1970 году ежегодные донорские поставки должны были возрасти до 500-600 куб.м. При этом стоимость одного кубического метра завезенного строительного песка со всеми транспортными расходами в 1966 году составляла от 8 руб. 60 коп. до 13 руб. (64). В этой связи стратегическое значение для развития новой отрасли в области приобретала стабильная высокопроизводительная работа региональных сырьевых карьеров, в числе которых исключительно важное место занимало расположенное в 30 км от Тюмени Переваловское месторождение строительного песка.

В начале 1966 года оно представляло собой весьма печальное зрелище. К нему не были подведены подъездные пути, отсутствовал торф для утепления карьера, не было построено помещение для обогрева рабочих. Водопроводная система не работала. Подогревателей масла и воды для функционирования техники в наличии не было. Приемное отделение не сумели отремонтировать. Сушильные шибера отсутствовали.

Областное управление промышленности строительных материалов пыталось в силу своих экономических возможностей исправить положение на Переваловском карьере и, прежде всего, усилить его строительными механизмами. Во 2-м квартале 1966 года ему было выделено два экскаватора мощностью 0,65 куб.м. и бульдозер C-300, что обеспечило добычу строительного песка в 1966 году на Переваловском месторождении в объеме 200 тыс. куб.м., а также рост экономии в размере 1,5 млн. руб. (65).

Однако было очевидно, что эпизодические финансовые вбрасывания в разработку этого уникального месторождения строительного материала лишь усугубляют общую кризисную ситуацию обеспечения им промышленных предприятий, производящих кирпич.

С особой остротой поэтому стала проблема системного финансового и технического обеспечения Переваловского месторождения нерудных полезных ископаемых. Его освоение было возложено на Тюменский кирпичный завод «Труд». При наличии собственных, весьма незначительных финансовых и материальных ресурсов, коллектив завода выполнил очень большой объем работы по строительству и монтажу Переваловского карьера, а также и добычи сырья на этом месторождении. В 1967 году за счет ссуд Госбанка была 
построена и введена в эксплуатацию трансформаторная подстанция карьера мощностью 3200 квт и стоимостью 60 тыс. рублей. Были приобретены и оборудованы 2 гидроклассификатора и другое оборудование общей стоимостью 35 тыс. рублей. За счет ощутимого для завода финансового напряжения удалось внедрить гидромеханизированный способ намыва товарного песка (66).

Всего на освоение Переваловского месторождения было израсходовано 260 тыс. рублей, из них за счет оборотных средств завода - 124 тыс. рублей и за счет ссуд госбанка - 136 тыс. рублей. Кроме того, было отвлечено из оборота завода и уплачено подрядной организации за намыв песка 72 тыс. рублей (67).

Такие финансовые расходы тяжелым бременем ложились на бюджет завода, отвлекали большие средства из основного производства и не позволяли его совершенствовать. К тому же значительные материальные потери завода были связаны с неукомплектованностью карьера взрывной техникой. Имеющиеся в распоряжении предприятия два земснаряда с сезонной производительностью 460 тыс. т. по этой причине за два года смогли выдать только 120 тыс. куб. метров песка. Для осуществления взрывных горных работ завод не имел квалифицированных кадров. Однако в связи с низкой оплатой труда такого рода специалистов он был ограничен в их наборе. Тем более это было невозможно сделать в силу того, что взрывные работы не были включены в планы производства и реализации товарной продукции кирпичного завода.

Это порожденное командно-административной системой управления экономикой противоречие производственной деятельности завода стало тормозить развитие Переваловского карьера, не позволяло наращивать объёмы добычи и выемки крайне необходимого для кирпичных заводов области сырья.

В связи с этим администрация завода «Труд» в целях быстрейшего развития Переваловского карьера и стабилизации работы непосредственного кирпичного производства обратилась в областное управление промышленности стройматериалов с предложением о выделении Переваловского карьера из подчинения кирпичному заводу «Труд» и создании специального предприятия по добыче нерудных материалов на базе Винзилинского и Переваловского месторождений песка и Режевского месторождения камня с непосредственным подчинением его специализированному Главку МПСМ «Главнеруд» (68).

Активно разрабатывались и другие варианты улучшения снабжения кирпичных предприятий глиной и песком. В целях приближения основного производства к сырьевым источникам и сокращения транспортных расходов в 
1968 году вблизи Воронинского месторождения на участке «Бабарынка» было начато строительство завода на 50 млн. штук стеновых материалов (69).

Инициативная работа руководства областного управления промышленности строительных материалов во главе с М.В. Хабаровым по созданию новой региональной отрасти экономики, несмотря на объективные трудности еe рождения, уже в первые годы своего развития давала впечатляющие результаты, отраженные в таблице № 3 (70).

Таблица № 3

Выполнение плана 1967 года предприятиями Тюменского областного управления промышленности строительных материалов (т.р.)

\begin{tabular}{|l|c|c|c|c|}
\hline \multicolumn{1}{|c|}{ Завод } & Отчет 1966 г. & План 1967 г. & Отчет 1967 г. & \% вып. к 1966 г. \\
\hline Кирпичн. 3-д № 1 & 307,6 & 521,1 & 500,0 & 162,5 \\
\hline Кирпичн. 3-д «Труд» & 613,5 & 559,8 & 512,0 & 83,1 \\
\hline Тобольск.Кир. 3-д & 62,0 & 57,7 & 44,6 & 92,6 \\
\hline ИшимскийКир. 3-д & 151,9 & 146,0 & 147,0 & 96,8 \\
\hline Силикатный 3-д & 673,0 & 1209,4 & 1303 & 149,3 \\
\hline Итого & 2008 & 2500 & 2520 & 125,3 \\
\hline
\end{tabular}

Данные таблицы свидетельствуют о значительном увеличении производства кирпича промышленными предприятиями областного управления. В целом его рост составил $25,3 \%$. Особенно заметное увеличение его объемов произошло на Тюменском кирпичном заводе № 1, составившее $62,5 \%$, а также на Тюменском силикатном заводе, достигшем 49,3\% роста при наихудших в области стартовых возможностях своего развития.

Силикатный завод в 1965 году, как мы отмечали, был сдан с большими недоделками. Однако уже к 1968 году рост производительности труда, по сравнению с годом пуска завода, вырос на $21 \%$. Выработка на одного рабочего в 1965году составляла 3385 руб., а в 1968 году она возросла до 4170 руб.

Одновременно перестройка предприятия на новый технологический поток позволила ему резко снизить затраты на 1 рубль товарной продукции, и из убыточного в 1967 году завода, когда затраты составляли 101,2 коп., за 9 месяцев 1968 года коллективу предприятия удалось добиться снижения затрат на 1 рубль товарной продукции в размере до 83,9 коп.

Увеличение объемов производства и снижение себестоимости продукции позволило вместо имевшихся ранее убытков, составлявших в 1966 году 1059 тыс. руб, а в 1967 году - 77 тыс. руб., получить по итогам 9 месяцев 1968 
года прибыль в размере 337 тыс. руб. при росте фондоотдачи с 0.52 коп в 1965 году до 0.63 коп. в 1968 году (71). В то же время, однако, осуществляемая реконструкция старых кирпичных заводов и расширение их площадей производства в 1967 году не позволили остальным кирпичным заводам управления выйти на показатели 1966 года.

Об объемах производства обжигового кирпича в натуральном выражении (тыс. штук) свидетельствуют данные таблицы № 4.

Таблица № 4

Объемы производства обжигового кирпича (тыс. шт. усл. кирп.)

\begin{tabular}{|l|c|c|c|c|}
\hline \multicolumn{1}{|c|}{ Завод } & Отчет 1966 г. & План 1967 г. & Отчет 1967 г. & \% вып. к 1966 г \\
\hline Кирпичн. з-д № 1 & 12574 & 25100 & 22600 & 179,6 \\
\hline Кирпичн. 3-д «Труд» & 13545 & 13000 & 13100 & 96,7 \\
\hline Тобольск. кир. 3-д & 2245 & 2500 & 2560 & 114,0 \\
\hline Ишимский кир. 3-Д & 5839 & 6400 & 6400 & 109,6 \\
\hline Силикатный з-д & 32706 & 48000 & 52700 & 170,3 \\
\hline Итого & 66913 & 95000 & 97360 & 145,3 \\
\hline
\end{tabular}

Показатели таблицы свидетельствуют о том, что даже в условиях реконструкции и нового строительства кирпичных заводов их трудовые коллективы не только не уменьшили производства стеновых материалов, но даже заметно его увеличили. Особого внимания заслуживают трудовые успехи завода силикатных изделий, труженики которого на оборудовании, принятом в 1965 году с большими недоработками, сумели произвести кирпича в 1967 году на 70\% больше, чем в 1966 году. Одновременно с этим строительство нового строительно-ремонтного участка и монтаж оборудования цеха № 1 на кирпичном заводе № 1 не стали причиной спада его производства. Более того, правильно определенная техническая стратегия руководства завода позволила после ввода в строй нового оборудования ликвидировать временное отставание производства промышленной продукции и обеспечить в 1967 году ее наивысший прирост среди предприятий Тюменского областного управления промышленности строительных материалов, составивший 79,6\% .

O динамике роста номенклатуры строительных материалов на предприятиях областного управления промышленности свидетельствует таблица № 5 (73). 
Таблица № 5

Рост номенклатуры строительных материалов на предприятиях

Тюменского областного управления

\begin{tabular}{|c|c|c|c|c|c|c|c|}
\hline $\begin{array}{l}\text { Наимен. } \\
\text { изделия }\end{array}$ & Ед. изм. & $\begin{array}{l}1965 \\
\text { Отчет }\end{array}$ & $\begin{array}{c}1967 \\
\text { Отчет }\end{array}$ & $\begin{array}{c}1967 \\
\text { Рост\% }\end{array}$ & $\begin{array}{l}1968 \\
\text { План }\end{array}$ & $\begin{array}{l}1968 \\
\text { Отчет }\end{array}$ & $\begin{array}{c}1968 \\
\text { Рост\% }\end{array}$ \\
\hline $\begin{array}{l}\text { Товарная } \\
\text { продукция }\end{array}$ & т.руб & 2518 & 4544 & 180,3 & 5200 & 4620 & 183,5 \\
\hline $\begin{array}{l}\text { Стеновые } \\
\text { материалы }\end{array}$ & млн. шт. & 46,3 & 98,3 & в 2 раза & 120,0 & 108,4 & в 2,2 раза \\
\hline $\begin{array}{l}\text { Кирпич } \\
\text { глиняный }\end{array}$ & млн.шт. & 38,9 & 40,3 & 104,1 & 48,0 & 47,1 & 121,2 \\
\hline $\begin{array}{l}\text { Кирпич } \\
\text { силикатный }\end{array}$ & млн.шт. & 6,3 & 50,4 & в 8 раз & 68,0 & 54,0 & в 10,6 раза \\
\hline $\begin{array}{l}\text { Изделия } \\
\text { гипсовые }\end{array}$ & т. $\mathbf{M}^{3}$ & 7,8 & 11,2 & 143,6 & 11,3 & 10,2 & 130,2 \\
\hline
\end{tabular}

Данные таблицы говорят о том, что в 1965-1967 гг. объем товарной продукции, выпускаемый предприятиями стеновых материалов, увеличился на 180,3 \%. Особенно интенсивно развивалось производство силикатного кирпича, обеспечивавшего потребности развернувшегося в области жилищного и промышленного строительства.

Из материалов таблицы видно, что более чем в два раза увеличился выход глиняного кирпича, намного опережая темпы роста строительства в области и успешно ликвидируя образовавшийся в середине 1960-х гг. дефицит этого базового конструктивного материала. При этом доминировало производство кирпича высокого качества. Например, на Тюменском силикатном заводе после преодоления трудностей с сырьевым обеспечением фактический выпуск кирпича по маркам составил М-150 - 4929 т. штук, М-125 - 5032 т. штук, M-100 - 15660 т. штук, М-75 - 7091 т. штук (74).

Еще более впечатляющими выглядят масштабы прогнозируемого выпуска стеновых материалов в 1968 году, согласно которым предприятия областного управления, как следует из таблицы, за этот год должны были произвести объем товарной продукции, равный предшествующему двухлетнему циклу его увеличения.

Достигнутые высокие производственные показатели не в последнюю очередь были обеспечены повсеместно развернувшимся на кирпичных заводах края социалистическим соревнованием. Мощным рычагом увеличения производства кирпича на предприятиях строительных материалов Западной Сибири являлось принятие повышенных трудовых обязательств, направленных 
на выявление резервов роста производительности труда, эффективности и рентабельности кирпичного производства, снижения его себестоимости.

Для достижения этих целей на предприятиях исследуемой отрасли особое значение имели мероприятия, направленные на улучшение культуры производства горячих цехов, их санитарного состояния, быта и повседневной жизни рабочих. Для севера Западной Сибири они являлись особенно актуальными, потому что производство строительных материалов существенно отличалось от других отраслей материального производства условиями, в которых осуществлялась их трудовая деятельность. Они характеризовались организационными, технологическими и санитарно-гигиеническим особенностями, которые оказывали большее негативное влияние, чем в других отраслях, на здоровье, физическое и моральное состояние работников и их отношение к выполняемым трудовым обязанностям. Среди этих факторов особенно большое значение имели санитарная обстановка на производственных участках, обеспеченность спецодеждой, возможностями ее обогрева и сушки, состояние воздуха в цехах, качество питания, условия отдыха, время продолжительности рабочего дня. Создание здоровых и безопасных условий труда на протяжении всего исследуемого периода имело огромное значение для формирования психологической атмосферы удовлетворенности рабочими своим трудом, что очень важно было в обстановке высокой кадровой текучести трудовых коллективов для достижения стабильности их штатного состава.

Заметную роль в активизации работы по улучшению рекреативных условий производства стеновых материалов в Тюменской области играли смотры-конкурсы культуры и санитарной гигиены производства. Для организации и проведения их из представителей профсоюзной, комсомольской и партийной организации создавались штабы, в задачи которых входила разработка условий проведения смотров и форм поощрения победителей на уровне цехов, участков, бригад и отдельных производственников. Смотры конкурсы являлись своего рода формой социалистического соревнования, которая пользовалась особой популярностью в трудовых коллективах стенового производства в силу того, что они, как это ни парадоксально, по своему гендерному составу были преимущественно женскими. Например, весь персонал Тюменского кирпичного завода № 1 насчитывал 251 человек, из которых 164 человека (66\%) являлись представительницами прекрасного пола. Их привлекало на это производство то, что, несмотря на тяжелую физическую нагрузку и нездоровую экологию в цехах, достаточно незамысловатые 
технологические приемы кирпичного производства, не требующие сложной квалификационной подготовки, легко усваивались женщинами. Не последнюю роль играли весьма высокие для этой категории работников заработки. Неслучайно поэтому то, что среди победителей смотра-конкурса производственной культуры и санитарной гигиены, проведенного 20 мая 1967 года на предприятиях Тюменского областного управления промышленности строительных материалов, со значительным преимуществом доминировали склонные к чистоте и порядку женщины (75).

В конце 1960-х - начале 1970-х гг. на предприятиях и учреждения всего Советского Союза особенно ответственно и организованно проводилось социалистическое соревнование в честь празднования 100-летия со дня рождения В.И. Ленина. Оно дало мощный толчок для расширения масштабов социалистического соревнования и совершенствования его форм. В 1971 году в ходе выполнения постановления ЦК КПСС и Совета Министров СССР «О развертывании Всесоюзного социалистического соревнования» на заводах стройматериалов Тюменской области были усовершенствованы и одобрены в производственных коллективах новые условия социалистического соревнования и формы поощрения, привлечены к его участию десятки новых трудовых коллективов и сотни тружеников кирпичного производства (76).

В 1974 году в социалистическом соревновании на предприятиях Тюменского областного управления стройматериалов приняли участие 1117 человек, в том числе в «Движении за коммунистический труд» - 565 рабочих, 10 цехов и 21 бригада. В результате социальной активности участников этого движения план 3-х лет 9-ой пятилетки по реализации промышленной продукции стеновых материалов был выполнен на 104,6\%, рост производства кирпича составил 106,1\%, силикатных изделий - 100,9\%. Сверх плана было произведено 9 млн. 300 тыс. штук кирпича, план отгрузки товарного песка был выполнен на 120 \%, рост производительности труда составил 100\%. Затраты на 1 рубль товарной продукции снизился на 1,6 копейки, себестоимость одной тыс. штук красного кирпича сократилась на 3 руб. 97 коп. (77).

Победители социалистического соревнования находились в центре внимания трудовой общественности Тюменской области. Их имена заносились на «Доски почета» предприятий, опыт достижения высоких производственных показателей обобщался и распространялся областными средствами массовой информации. В 1973 году 111 работников предприятий стеновых материалов Тюменского областного управления были награждены орденами и медалями, 
170 человек отмечены значками «Отличник социалистического соревнования 1973 г.», сотни его участников поощрены грамотами и ценными призами (78).

Успешное выполнение принятой программы выпуска стеновых материалов являлось важным условием масштабного жилищного и капитального строительства на территории ХМАО-Югры. Тюменская область все в большей мере становилась самодостаточным субъектом производства строительных материалов и стеновых конструкций.

Заметную роль в выполнении государственных заданий предстояло сыграть и ветерану - кирпичному заводу «Труд». В исследуемый период он претерпел показательную эволюцию. На основании приказа Министерства промышленности строительных материалов РСФСР от 04.02.1974 № 62 17 марта 1974 года был введен в эксплуатацию завод строительных материалов Производственного объединения «Тюменьстройматериалы». В марте 1977 года произошло его объединение с Тюменским кирпичным заводом «Труд» и был создан единый «Тюменский завод строительных материалов» (79).

С образованием нового крупного завода строительных материалов существенно возрос объем выпускаемой продукции, обновился её ассортимент, открылись новые цеха: керамической фасадной плитки (КФП), бетоннофасадной плитки (БФП), бетонно-мозаичной плитки (БМП) (80).

В ходе экономических реформ периода «перестройки» на основании приказа Министерства промышленности строительных материалов РСФСР от 14 января 1989 № 24 и приказа ТПО «Тюменьстройматериалы» от 17 января 1989 № 5 Тюменский завод строительных материалов был ликвидирован и в соответствии с законом о кооперации СССР в целях повышения эффективности производства и увеличения выпуска строительных материалов. Для удовлетворения потребностей народного хозяйства и населения на базе Тюменского завода строительных материалов 1 апреля 1989 года был создан кооператив «Сибстройматериалы». Этот кооператив решением Исполкома Калининского районного Совета народных депутатов от 20.04.1989 № 97 и приказа Тюменского завода строительных материалов от 23.01.1989 № 6 был зарегистрирован при Территориальном производственном объединении (ТПО) «Тюменьстройматериалы» Министерства промышленности строительных материалов РСФСР (81).

Основной задачей кооператива являлось использование производственных мощностей для производства строительных материалов: простой керамической плитки, керамической фасадной плитки, бетонно- 
мозаичной плитки, плитки бетонно-фасадной на основе белого цемента. Кооператив начал осуществлять также выпуск продукции сверх госзаказа, включающий производство разнообразных товаров народного потребления, и оказывать услуги населению в строительстве и ремонте жилья.

В ходе расширения его хозяйственно-производственной деятельности на основании приказа Министерства промышленности строительных материалов РСФСР от 17.05.1989 № 243 было создано Территориальное производственное кооперативное объединение (ТПКО) «Тюменьстройматериалы», а территориальное производственное объединение «Тюменьстройматериалы» и его структурные подразделения были ликвидированы.

Основные фонды ТПО «Тюменьстройматериалы», в том числе кооператив «Стройматериалы», были переданы на условиях аренды вновь созданному «Территориальному производственному кооперативному объединению «Тюменьстройматериалы» (82), который 1 декабря 1989 года стал филиалом ТПКО «Тюменьстройматериалы» и был переименован в Тюменский комбинат строительных материалов - филиал ТПКО «Тюменьстройматериалы» (83).

В штатном расписании филиала в 1990 году уже значились такие структурные подразделения, как АУП, производственно-технический отдел, планово-экономический, отдел главного механика, отдел главного энергетика, цеха № 1, 2, цех КФП, цех БМП, отдел материально-технического снабжения, отдел технического контроля, отдел капитального строительства, транспортный цех (84).

В соответствии с законом РСФСР «О предприятиях и предпринимательской деятельности» и постановления главы администрации Калининского района города Тюмени филиал комбината строительных материалов ТПКО «Тюменьстройматериалы» 1 января 1993 года был преобразован в товарищество с ограниченной ответственностью (ТОО) «Комбинат строительных материалов», а в апреле 1997 года на его основе было создано открытое акционерное общество (ОАО) «Комбинат строительных материалов» (85).

В ходе выполнения намеченной в середине 1960-х годов программы развития стройиндустрии в Тюменской области вводились в строй и успешно действовали другие предприятия отрасли. В 1965 году было закончено строительство первой очереди Винзилинского завода силикатных изделий производственной мощностью 50 млн. штук силикатного кирпича в год. В 
ноябре 1965 года начался выпуск промышленной продукции, а в 1966 году было произведено уже 32,7 млн. штук кирпича (86).

Год своего двадцатилетия завод встретил отличными показателями. К 1985 году было выпущено 2 млрд. 100 млн. штук силикатного кирпича и 240 тыс. кв. м облицовочной плитки. В 1980-е гг., несмотря на бурное развитие крупнопанельного домостроения, потребность в стеновых материалах в общем объеме строительства жилья и объектов соцкультбыта оставалась достаточно высокой. Винзилинский завод силикатных изделий был самым большим в области по выпуску стеновых материалов. Он изготавливал около 50 \% всего объема кирпича, выпускаемого предприятиями Главка (87).

Яркий след в истории производства строительной продукции Тюменской области оставил Ялуторовский завод стеновых материалов, начавший производство кирпича еще в 1971 году и ставший основой современного холдинга «Поревит» - модернизированного предприятия по производству стеновых блоков из автоклавного газобетона, силикатного кирпича и силикатных пазогребневых блоков в Урало-Западносибирском регионе. Его открытие состоялось 22 апреля 2009 года. Завод оснащен автоматизированными линиями производства немецкой фирмы MASA HENKE MaschinenfabrikGmbH. Его производственная мощность составляет 300 тыс. м ${ }^{3}$ газобетона и 110 млн. условных штук кирпича в год (88).

Таким образом, в 1960-е гг. в процессе производственного и социального освоения Западно-Сибирской нефтегазоносной провинции трудовыми коллективами новой энергетической провинции были заложены основы строительной индустрии Тюменского Севера. Продолжая её славные традиции, созданные предприятия прошли непростой путь экономического реформирования и хозяйственной реорганизации, в ходе которого сумели сохранить и приумножить свой экономический и творческий потенциал, наращивая его в наши дни.

\section{Примечания}

1. Государственный архив социально-политической истории Тюменской области (ГАСПИТО). Ф.124. Оп.91.Д.75.Л.74-75.

2. Там же.

3. Режим доступа: www.trsm 72.ru Тюменский комбинат строительных материалов 
4. Краткий справочник по фондам Государственного архива Тюменской области. Тюмень: Изд-во «Вектор бук», 2002, с.6.

5. Режим доступа: www.trsm 72.ru Тюменский комбинат строительных материалов.

6. Краткий справочник по фондам Государственного архива Тюменской области. Тюмень: Изд-во «Вектор бук», 2002, с.5

7. Государственный архив Тюменской области (ГАТО), Ф.2085, Оп.1. Д.266. Л.7.

8. Там же. Л.23.

9. ГАТО. ф.2085. Оп.1. Д.22. Л.23.

10. Краткий справочник по фондам Государственного архива Тюменской области. Тюмень: Изд-во «Вектор бук», 2002,с.6

11. Режим доступа: www.trsm 72.ru Тюменский комбинат строительных материалов

12. ГАТО, ф.2085, оп.1, д.25, л.2.

13. Там же. Л.4

14. ГАТО, ф.2085, оп.1, д..25, л.77.

15. ГАТО, ф.2085, оп.1, д.20,л.19.

16. ГАТО. Ф.2085. Оп.1.Д.15.Л.32.

17. ГАТО, ф.2085, оп.1, д.20, л.19.

18. ГАТО, ф.2085, оп.1, д.32, л.8.

19. ГАТО, Ф.2085, ОП.1, Д.23, Л.5

20. ГАТО, ф.2085, оп.1, д.20, л.7.

21. ГАТО, ф.2085, оп.1, д.20, л.7.

22. ГАТО, ф.2085, оп.1, д.267, л.34..

23. ГАТО, ф.2085, оп.1, д.225, л.67.

24. ГАТО, ф.2085, оп.1, д.20 л.2.

25. ГАТО, ф.2085, оп.1, д.161, л.13.

26. ГАТО, ф.2085, оп.1, д.98, л.7.

27. ГАТО, ф.2085, оп.1, д.275, л.7.

28. ГАТО, ф.2085, оп.1, д.98, л.11.

29. Там же.

30. ГАТО, ф.2085, оп.1, д.861, Л.111.

31. ГАТО, ф.2085, оп.1, д.245, л.71.

32. ГАТО, ф.2085, оп.1, д,161, л.111.

33. ГАТО, ф.2085, оп.1, д.249, л.77 
34. ГАТО. Ф.2085. Оп.1.Д.119.Л.23

35. ГАТО, ф.2085, оп.1, д.98, л. 17

36. Там же, Л.19.

37. ГАТО, ф.Л.20.

38. Там же.

39. Там же.

40. ГАТО. Ф.2085.Оп.1.Д.249.Л.77.

41. Там же.

42. Там же.Л.71.

43. Там же.

44. ГАТО. Ф.2085.Оп.1.Д.391.Л.110

45. ГАТО, ф.2085, оп.1, д.92, л. 83

46. ГАТО, ф.2085, оп.1, д.23, л.5

47. ГАТО, ф.2085, оп.1, д.98, л.30

48. ГАТО, ф.2085, оп.1, д.29, л. 23

49. ГАТО, ф.2085, оп.1, д.92, л.73.

50. ГАТО, ф.2085, оп.1, д.39, л.7

50. ГАТО, ф.2085, оп.1, д.29, л.65.

51. ГАТО, ф.2085, оп.1, д.78, л.57

52. Там же, л.7.

53. Там же, л. 8

54. ГАТО, ф.2085, оп, 1, д.11, л.10.

55. ГАТО, ф.2085,оп.1, д.15,л.23.

56. ГАТО, ф.2085, оп.1, д.5, л.65.

57. ГАТО, ф.2085, оп.1, д.78, л.7

58. ГАТО, ф.2085, оп.1, д.29, л.47

59. Там же.

60. ГАТО. Ф.2085, оп.1,д.266, л.9.

61. ГАТО, ф.2085, оп.1, д.225, л. 70

62. ГАТО, ф.2085, оп.1, д.32, л.60.

63. ГАТО, ф.2085, оп.1, д.249, л.77

64. ГАТО, ф.2085, оп1, д.15, л.33.

65. Там же.

66. ГАТО, ф.2085, оп.1, д.33, л.2.

67. Там же, л.3.

68. Там же. 
69. ГАТО, ф.2065, оп.1, д.32, л.60.

70. ГАТО, ф.2085, оп.1, д.98,л.27.

71. ГАТО, ф.2085, оп.1,д.32,л.34.

72. Там же.

73. ГАТО, ф.2085, оп.1,д.32,л.48

74. Там же.

75. ГАТО, ф.2085, оп.1, д.32, л.33

76. ГАТО, ф.2085, оп. 1 , д.92, л. 80.

77. Там же, л. 8

78. Там же, л.77.

79. ГАТО, ф.1861, оп. 1 ,д.228,л.2

80. Там же.

81. Режим доступа: www.trsm 72.ru. Тюменский комбинат строительных материалов.

82. Там же,

83. Там же.

84. Там же.

85. Там же.

86. Режим доступа:zavodfoto.Likejournal.com. История промышленности России в фотографиях: ООО «Инвест-селикат-стройсервис».

87. Там же.

88. Режим доступа: www.tyumen-city.ruviasat...administrativekatalogyfondov 


\section{ГЛАВА 4. \\ ГЛАВК «ГЛАВТЮМЕННЕФТЕГАЗСТРОЙ» В ГРАДОСТРОИТЕЛЬСТВЕ ХМАО-ЮГРЫ}

Успешное выполнение принятых планов выпуска стеновых материалов кирпичными заводами Тюменской области, расширение географии их ввода в строй и появление на некоторых участках заводских площадей новых механизированных цехов производства стеновых материалов свидетельствовало о процессе ускоренного развития на севере Тюменской области новой для структуры ее экономики строительной отрасли. Но это отнюдь не означало, что данная территория становилась самодостаточным субъектом экономики сибирского севера, обладающим индустрией производства компонентов механизированной технологии капитального, гражданского и жилищного строительства.

Отдельные сооружения из кирпича начали активнее строить в местах расселения прибывающей на север рабочей силы. Но наиболее массовыми домами в 1960-е гг. продолжали оставаться комплектно-брусовые 8-12-16квартирные дома, производство которых осуществлялось на Богородском заводе строительных материалов. В 1964 году для создаваемых в Тюменской области поселков и городов, предприятий и организаций «Тюменнефтегаз» Тюменского территориального геологического управления и Государственного комитета по газовой промышленности СССР трудовой коллектив Богородского завода взял на себя обязательство изготовить 10 тыс. кв.м. таких домов, а в 1965 году довести их производство до 24 тыс. кв.м. (1).

В ряде случаев в местах расселения нефтяников сооружались двухэтажные и трехэтажные дома с деревянными перекрытиями. При постройке этих, называемых в народе "сталинскими", домов вручную клали кирпичи. Каждый проект, можно сказать, был индивидуальным. Темпы строительства не могли даже в малой степени удовлетворить потребность в жилье, которую испытывали прибывающие нефтяники и газовики, энергетики и строители, учителя и врачи. А она была колоссальной. Только счастливчики жили в таких строениях. Значительная часть мигрантов селилась в унизительных условиях временных балков, вагонов и другого ветхого жилье.

При этом на строительство жилья, судя по критическому выступлению председателя Сургутского горисполкома П.А. Мунарева 31 января 1969 года на Пленуме Ханты-Мансийского окружного комитета КПСС, «стали отпускать 
меньше средств, чем в предыдущие годы. Если в 1964 году было введено в эксплуатацию 33 тыс. кв. метров жилья, то в 1968 году- 25700 кв. метров». В 1968 году в Сургут прибыло 5128 человек. Численность его населения составила 27728 человек. Для того, чтобы расселить такое количество людей согласно нормативам, необходимо было ежегодно вводить 60 тыс. кв. м жилой площади. Однако в 1969 году в Сургуте не имели ни одного квадратного метра жилой площади такие крупные предприятия, как СУ-4 с количеством работающих 444 человека, мехколонна № 55, где насчитывалось 203 человека, мехколонна № 14 с числом работающих 220 человек, нефтепроводное управление, где трудилось 328 рабочих и специалистов, СУ-19, где нуждались в жилье 152 человека, предприятия связи с 239 почтальонами и телеграфистами и ряд других крупных организаций. В городе насчитывалось более двух тысяч балков и вагончиков (2).

Однако оптимизм и уверенность в будущей благоустроенной жизни не покидали сургутских эмигрантов. Об этом свидетельствуют иронические названия улиц их стихийных поселений. Летом 1964 года на западной окраине Сургута, у кромки картофельного поля колхоза «Красный северянин», сегодня это район улиц Ленина и Дзержинского, выросла небольшая странная жилищная агломерация нефтяников, состоящая из металлических вагончиков. В них жили работники управления, туда же переехал и его главный штаб. Народная молва единственной улице этого железного поселка присвоила имя уважаемого человека, заботливого коменданта НПУ Доры Семеновны Охремчук. Позднее металлические вагончики стали обрастать множеством деревянных балков, статус поселка повысился, и он закрепился в истории Сургута под названием «Таратыновка». Так простыми людьми в шутку или всерьез было увековечено в истории города имя уважаемого руководителя Бориса Николаевича Таратынова, заместителя начальника НПУ по кадрам и быту, военного моряка, капитана второго ранга, участника Великой Отечественной войны (3). Очень популярными и хорошо известными почтальонам города стали и другие названия балковых мегаполисов, запечатлевшие фамилии первых руководителей промышленного освоения Западной Сибири, «Чабанград», «Сабирзяновка», «Бикбовка» (4).

Вполне очевидно, что в этих гротесковых названиях стихийных поселений содержалась большая доля недовольства тружеников города своим жилищным положением. С особенно большим сарказмом оно выражалось в ярком названии вагон-городка газовиков, именуемом в народе «Золотой 
эшелон». Там даже в 1980 году насчитывался 581 вагон (5), занятый под жилье, a 112 вагонов служили бытовыми помещениями (6). Пик вагоно-балкового жилищного бума в Сургуте приходится на начало 1970-х гг. Тогда в нем насчитывалось до 32 тыс. таких градостроительных шедевров (7).

Аналогичная жилищная панорама просматривалась в эти годы во всех строящихся городах Югры. Между тем в это же время в Москве инженеры и архитекторы трудились над конструкцией первых сборных крупнопанельных домов. Еще раньше, в 1947-1948 гг., на Соколиной Горе под общим руководством инженера В.Ф. Промыслова коллективом авторов «Горстройпроекта» и «Института строительной техники Академии строительства и архитектуры СССР» в лице архитекторов В.И. Богомолова, Н.М. Фукина, инженеров Г.Ф. Кузнецова, Б.Н. Смирнова, Н.В. Морозова, В.А. Вольнова был сооружен первый в стране четырехэтажный каркаснопанельный дом (8).

Несущий каркас этого здания был выполнен из профильного металла. Панели наружных стен представляли собой многослойные, с двумя слоями асбестоцементных плит, толщиной 40 см каждый, утеплители, состоявшие из двух основных элементов: узких вертикальных панелей-простенков высотой на этаж, образующих на фасаде пилястры и межоконные вставки. Панели перекрытий в виде узких ребристых плит с подшивным потолком из гипсовой сухой штукатурки имели размер 3,25 х 0,5 м. Межквартирные и межкомнатные перегородки монтировались из гипсовых плит. Хотя конструкция этого дома, с точки зрения современных требований сборного строительства, была далеко не совершенна и требовала выполнения большого объема работ на строительной площадке и большого расхода металла в количестве 16 кг на 1 м $^{3}$ здания, его строительство явилось первым производственным опытом по возведению многоэтажных домов из сборных элементов (9).

В 1958 году архитекторами коллектива «Гипростройиндустрии», включающего инженеров В.Г. Кочешкова, А.Г. Розенфельда, И.П. Полозова, при участии архитектора И.Ю. Марковой, инженеров Л.С. Евгеньевой, В.И. Сысоевой, А.А. Кирилловой, Н.П. Грачева под руководством Н.П. Розанова была разработана серия усовершенствованного типового проекта крупнопанельных домов, получившая шифр I-464, утвержденная Госстроем СССР для массового строительства.

В типовых проектах серии I-464, по замечаниям экспертизы Госстроя СССР, были изменены продольные шаги с 3,4 и 2,65 на 3,2 и 2,6, а также 
снижена конструктивная высота с 3 до 2,7 м. Экономичные планировочные решения домов этой серии обеспечили относительно низкую стоимость $1 \mathrm{~m}^{2}$ жилой и полезной площади, сокращение затрат труда и расхода основных материалов - стали и цемента. Первые годы массового строительства бескаркасных крупнопанельных домов серии I-464 в различных климатических и геологических условиях подтвердили их конструктивную надежность и технико-экономические преимущества, по сравнению с жилыми домами традиционных конструкций. Их трудозатраты были ниже традиционных на 30-40\%, вес зданий на 30-40\% меньше, сроки строительства короче в среднем в

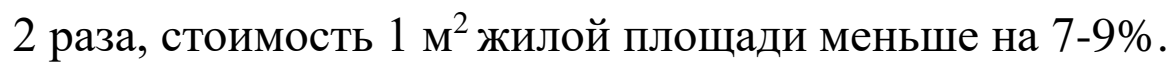

Для производства комплектов сборных изделий серии I-464 институтом «Гипростройиндустрия» были разработаны типовые проекты заводов с комплектами технологического оборудования производительностью 35,70 и 140 тыс. м² жилой площади в год (10). Они в целом отвечали требованиям утверждавшейся в стране новой революционной технологии домостроения. Но не в полной мере.

Эти четырехэтажные дома, возведенные первоначально в Кузьминках и на улице Кууссена, были построены из прокатных панелей. Наружные панели для этих домов были вертикальными - высотою в два этажа. С инженерной точки зрения, а особенно с точки зрения технологии производства, эти дома были еще очень далеки от совершенства. Поэтому московские проектировщики интенсивно работали над конструкцией нового крупнопанельного пятиэтажного дома. Им стал Дом серии К-7, созданный на основе идеи архитектора Виталия Лагутенко - руководителя первой мастерской Моспроекта. Строили дома этой серии на основе продукции Краснопресненского завода железобетонных конструкций, на базе площадей которого затем был основан ставший известным в стране Московский домостроительный комбинат № 1 .

Проект серии К-7, основанный на кассетной технологии, ставшей ключевой для Московского домостроительного комбината, используется до сих пор. Смысл ее состоит в том, что одновременно можно изготовить не одну-две, a сразу десяток готовых панелей. Дом К-7 был достаточно прост для изготовителей, и в этом заключалось его главное достоинство. Пятиэтажка состояла всего из двух десятков наименований изделий. И поэтому заводы все необходимые операции смогли освоить довольно быстро. В 1958-1964 гг. в Москве были возведены первые в мировой практике заводы сборных 
железобетонных изделий - Люберецкий и Шелепинский, производительностью каждый по 120 тыс. м. ${ }^{3}$ в год с контейнерным способом производства. Это положило начало широкому внедрению в строительство крупноразмерных сборных железобетонных элементов, изготовляемых заводами механизированным способом. Проекты заводов были разработаны Гипростроймашем и Минстройдором. Их авторами являлись инженеры А.А. Сусников (руководитель проекта), В.А. Каличев, А.А. Горский, архитектор Н.П. Розанов и другие. Дома серии К-7 легли в основу жилищного строительства в Москве (11).

В городах Западной Сибири застройка велась первоначально более экономичными и малозатратными «хрущевками» серии 1-464 Института Гипростройиндустрии, а также сериями 1-335 и 1-439 А, которые, однако, не соответствовали климату северных регионов.

Начиная с 1970-х гг. наиболее распространенными стали дома, которые были разработаны ЛенЗНИИЭПом - «ленпроектовские дома». Они пришли на смену вызывавшими нарекания югорчан устаревшим проектам. Наиболее известными являются дома серии 112, проект которых был разработан институтом для районов с вечномерзлотным грунтом, что для широт Тюменского севера стало наиболее приемлемым вариантом домостроения (12).

В 1959-1962 гг. в СССР было возведено около 200 заводов крупнопанельного домостроения общей площадью 15 млн. м (13), и на начальном этане застройки новых городов Ханты-Мансийского автономного округа предпринимались попытки обеспечить ее потребности за счет ввоза в Сибирь домостроительных материалов и конструкций.

До создания собственной индустрии строительства на севере Западной Сибири основным источником обеспечения градостроения материалами и конструкциями являлось увеличение их производства на предприятиях Минпромстроя и Минпромстройматериалов. До пуска Сургутского домостроительного комбината в 1971 году расположенные вблизи формирующегося Западно-Сибиркого нефтегазового комплекса наиболее мощные из них являлись основными поставщиками металлоконструкций первых собираемых в Сибири крупнопанельных домов. Первые «малосемейки» - жилые строения 467 серии и старые «моспроекты» 464 серии - строились из привозного железобетона, который транспортировался из Свердловска, Омска и Новосибирска. От долгой транспортировки и многочисленных перевалок на станциях и причалах изделия ломались. В результате, как вспоминал главный 
архитектор Сургута В.И. Унжаков, «из пяти домов собирали два-три. В микрорайоне геологов до сих пор стоят дома, укрепленные металлическими каркасами, потому что они собирались из битых панелей» (14).

$\mathrm{He}$ в полной мере обеспечивался и прием поступающих строительных конструкций. В акте проверки сохранности поступающих ценностей отмечалось, что Строительное управление № 9 не обеспечивает сохранности поступающих ценностей. Грузы в момент поступления не проверяются, приходуются несвоевременно, ответственных лиц для проверки жилых домов, знакомых с их комплектацией, не выделяется» (15).

Слабые возможности приема и хранения строительно-монтажных конструкций усугублялись несвоевременными поставками стройматериалов. Как правило, они прибывали с большими задержками. Первая баржа со строительными материалами и инструментами доставила необходимый для исторического Усть-Балыкского месторождения груз только 26 июля 1964 года, а по плану первые суда должны были пришвартоваться в Сургуте ещё в мае для отправки в Омск нефтеналивных танкеров. Основное же поступление материалов началось лишь в середине августа и сентябре того года. Такое резкое, незапланированное поступление строительных материалов и инструментов затрудняло организацию работ по их выгрузке и складированию. В результате этого они были не размещены, а фактически брошены на берегу реки Обь за 12 км от Сургута (16).

Руководители Сургута, Урая, Нфтеюганска активно поддерживали инициативу Тюменского обкома КПСС, который еще в 1963 году принял решение о создании опорной базы поставки стройматериалов в г. Тюмень и запланировал строительство механизированного речного причала с объемом строительно-монтажиых работ на 1964 год в размере 450 тыс. руб. (17). Разработанная проектная и сметная документация включала в себя сооружение уникальных причальных объектов и железнодорожных подъездных путей на сумму 288,4 тыс. рублей (18).

Учитывая то, что развитие нефтедобывающих районов Тюменской области и их обустройство является важнейшей народнохозяйственной задачей, Совет Министров РСФСР еще 16 сентября 1964 года в своем специальном постановлении «О мерах по оказанию помощи в освоении нефтяных месторождений в Тюменской области» настоятельно потребовал от совнархозов, министерств и ведомств РСФСР, крайисполкомов и облисполкомов «принять необходимые меры по оказанию помощи в 101 
обустройстве этих районов и усилению контроля за своевременной поставкой строительного сырья, материалов и оборудования, выделяемых для этой цели» (19). Для решения этой задачи на реках Сибири, в городах Новосибирске, Томске, Омске, Тюмени, Тобольске и Лабытнангах сооружались базы материально-технического снабжения с подъездными железнодорожными путями, причальными сооружениями и автотранспортными участками. Это постановление ЦК КПСС последовательно выполнялось и создавало благоприятные условия для расширения возможностей второго источника поставок домостроительных панелей на север Тюменской области, каковыми являлись межобластные поставки.

В соответствии с Постановлением Совета Министров РСФСР от 16 сентября 1964 года Министерство строительства РСФСР планом на 1965 год предусматривало изготовление и поставку сборного железобетона и деталей крупного домостроения для обустройства нефтяных районов Тюменской области в объеме 60 тыс. м ${ }^{3}$ в том числе: «Главзапсибстрой»- 20 тыс. м ${ }^{3}$ (15 тыс. м ${ }^{2}$ жилой площади), «Главкузбасстрой» - 20 тыс. м ${ }^{3}(10$ тыс. м² жилой площади), «Главсредуралстрой» - 20 тыс. м³ (15 тыс. м² жилой площади (20). Планом межтерриториальных поставок строительных материалов, утвержденным Советом Министров РСФСР, предусматривалось в том числе ввести в 1968 году в Тюменскую область 100 млн. штук кирпича (21).

Однако Главснабсбыт РСФСР был в значительной степени ограничен в такого рода поставках из-за дефицита производства железобетонных конструктивных материалов стеновых панелей на предприятиях стройиндустрии Российской Федерации и трудностей осуществления их доставки из других экономических районов Советского Союза.

Поэтому для более полного удовлетворения потребностей жилищного и капитального строительства Тюменской области в стеновых железобетонных металлоконструкциях Главснабсбыт РСФСР особое внимание сосредоточил на создании региональной промышленности и обратился к Тюменскому обкому КПСС с убедительной просьбой «принять меры по увеличению их производства на действующих предприятиях региона» (22).

Однако сделать это было в Тюменской области в то время исключительно трудно. В первой половине 1960-х гг. Тюменская область представляла собой огромный сельскохозяйственный район, а в ХМАО доминировали лесная промышленность и добыча рыбы. Имеющиеся в то время в наличии строительные организации как в Тюменской области, так и в округе создать 
«индустриальную базу строительства» объективно не могли. Об этом в июне 1960 года, чуть более чем за год до открытия Усть-Балыкского месторождения, на пленуме Тюменского областного комитета КПСС подчёркивалось большое значение для перспективного развития экономики области и ее урбанизации открытие месторождения нефти в Шаиме: «Открытие в районе поселка Шаим на реке Конде запасов нефти внесёт большую поправку в сторону увеличения темпов роста развития производительных сил области». Откровенно говорилось, что «развитие строительной индустрии и производство строительных материалов в области не только не опережают темпы строительства, но даже резко отстают и тем самым сдерживают промышленное, культурно-бытовое и жилищное строительство» (23).

В Тюменской области и его субъектах не было достаточной производственной базы ни в одной строительной организации, ни в совнархозе, ни в управлениях и трестах, подчинённых облисполкому. Большинство областных строительных организаций имели низкий технический уровень и являлись кустарными или полукустарными предприятиями.

Отсталость строительной индустрии в области характеризовалась основным показателем, определяющим уровень индустриального строительства и фиксирующим расход сборного железобетона на миллион рублей выполненных строительных работ. Если в целом по стране расход сборного железобетона в 1959 году на один миллион рублей строительномонтажных работ составил 175 кубометров, то в Тюменской области производство сборного железобетона в 1959 году достигло всего лишь 59 кубометров на один миллион рублей стоимости строительно-монтажных работ. (24) При этом строительные организации, подведомственные облисполкому, сборный железобетон почти не применяли (25).

Потребность строительных организаций в сборном железобетоне в Тюменской области в 1960 году, за год до открытия Усть-Балыкского месторождения, составляла около 100 тыс. кубометров, а предприятия совнархоза и облисполкома могли реально выпустить лишь 30,0 тыс. кубометров, в том числе предприятия совнархоза - 25 тыс. кубометров (26).

Для ввода в строй в области новых объектов строительной индустрии не хватало капиталовложений, и многочисленные ранее действующие объекты производственной базы строительства были законсервированы. Например, ещё в 1961 году по заказу Тюменского совнархоза началась разработка проектных 
заданий для строительства в городе стекольного завода. Однако в течение 7 лет к его строительству не приступали в силу недостатка финансирования.

Трестом «Тюменьгорстрой» с 1954 года строился завод сборного железобетона, но к началу 1960-х гг. он так и не был введен в эксплуатацию. С 1962 года в Тюмени строилась Промбаза № 1, которая по планам должна была стать основным поставщиком сборного железобетона и стеновых панелей для жилищного строительства. Однако в 1962-1964 гг. на её строительство было выделено всего $20 \%$ сметной стоимости, а задача ввода в строй в 8-й (1966-1970 гг.) пятилетке вообще не ставилась. Деревообрабатывающий цех в Тюмени мощностью 20 тыс. м ${ }^{3}$ переработки древесины в год из-за отсутствия ассигнований на завершение его строительства в течение 6 лет находился на консервации. По этой же причине были заморожены строительство Тюменского керамзитового завода и базы строительной индустрии в Тобольске. Немногочисленные, функционирующие в Тюменской области строительные организации «Минпромстроя» были маломощными, недостаточно оснащенными машинами и механизмами, они не имели своего технологического автотранспорта, типовых технических училищ по подготовке кадров, их рабочие были слабо обеспечены жильём и социальными объектами (27).

Строительная индустрия требовала высококачественных заполнителей: щебня, гравия, песка. Добыча и переработка нерудных материалов в области находилась на крайне низком техническом уровне.

Имеющиеся в ведении областной местной промышленности карьеры Богдановический и Тюменский, расположенные в Свердловской области, являлись полукустарными предприятиями, выпускающими дорогую, но низкопробную продукцию. Щебень из этих карьеров поставлялся на стройки области несортированным по фракциям, смешанным с остатками земли и глины. Гравий и песок также имели примеси других пород.

Неудовлетворительное состояние щебня, гравия и песка вызывало увеличение расхода цемента в бетоне и снижало его качество, не удовлетворяло потребности строек в инертных материалах.

В 1960 году, накануне открытия «большой нефти» в Нефтеюганске, для всех строек Тюменской области требовалось 640 тыс. кубометров камня, щебня и гравия. Эта потребность за счёт производства обеспечивалась только на 50\%. Дефицит нерудных ископаемых частично компенсировали поставки из других областей. Основной поставщик гранитного камня Тюменский межкарьер был 
слабо оснащён механизмами, имел экскаваторы небольшой ёмкости, не соответствующие работе в скальном грунте. Дробильно-сортировочное хозяйство было также маломощно, установка дробилок и сортировок носила временный характер, их недостаточное количество не позволяло организовать приготовление и сортировку щебня по фракциям, тщательную их очистку от примесей (28).

Кулаковское месторождение, расположенное возле города Тюмени, имело незначительный запас гравия. Он залегал на небольшой глубине, но размещался тонкими пластами, затрудняющими его механическую разработку. Возрастающую потребность строительства в гравии это месторождение обеспечить не могло (29).

Соблюдение технологических требований промышленной добычи углеводородного сырья включало в себя осуществление последовательного ряда сложных инженерно-технических и строительных операций. Они требовали опережающего выделения дополнительных финансовых средств.

Поэтому освоение нефтегазовых месторождений в ХМАО-Югре и на всем Тюменском Севере со сложными природно-климатическими условиями начало осуществляться без подготовки строительной, инженерной и социальной инфраструктур. Речные порты, автодороги, электроэнергетику, аэропорты, жилые и социальные объекты пришлось строить не до сооружения непосредственных производственных механизмов извлечения и приёма нефти, а после них.

В то время производственно-технологический потенциал НПУ «Сургутнефть» составляли два нефтепромысла на Усть-Балыкском и Мегионском месторождениях, цех научно-исследовательских и производственных работ, строительный участок с двумя прорабскими участками в Сургуте и Нефтеюганске. Однако их строительные и технические возможности не были достаточными для реализации такой масштабной работы на крупнейших в стране месторождениях собственными силами. Большую помощь нефтяникам в решении их производственных задач оказывали геологи Сургутской нефтеразведочной экспедиции и работники Сургутского рыбокомбината. Специалисты этих подразделений в собственных механических мастерских производили наладку оборудования. Нефтяникам передал несколько восьмиквартирных домов рыбокомбинат, а местный райпромкомбинат поставил пиломатериалы и столярные изделия. Сургутская речная пристань отдала под жильё работникам НПУ «Сургутнефь» здание 
вокзала, а совхоз «Юганский» - помещение под контору управления. Жители Сургута радушно приглашали к себе для проживания новоселов (30).

Однако развернуть работы по бурению эксплуатационных скважин нефтяникам «Сургутнефти» в 1964 году в полном объёме не удалось. УстьБалыкской конторе бурения, где был основан первый нефтяной промысел, задание по бурению из-за тяжелейших бытовых условий оказалось не по силам. У нефтяников не было своей конторы, заведующий промыслом не имел даже письменного стола. Участок Уфимского строительного управления не выполнил план по строительству жилья: зимой рабочие вынуждены были жить в палатках и балках (31).

Мегионский нефтепромысел, который в августе 1964 года отделился от «Сургутнефти» и стал самостоятельным управлением «Мегионнефть», до конца 1964 года так и не смог приступить к буровым работам во многом из-за нерешённости аналогичных проблем (32).

Опыт развития крупнейших по тому времени нефтяных регионов Татарии и Башкирии порождал у ведомственных руководителей скептическое отношение к возможности выполнения в ХМАО-Югре поставленных задач строительства и создания в максимально короткие сроки нового энергетического центра страны.

Для таких настроений имелись реальные основания. Строительное управление № 9, созданное на базе Сургутского прорабского участка, собственными силами план строительно-монтажных работ на 1964 год по промышленному строительству выполнило только на 30,7\%, а по культурнобытовому - на 8,7\%. Такой фактический срыв плановых заданий был связан со слабой кадровой укомплектованностью рабочими подразделений управления. Кадровый состав Строительного управления № 9 в июле 1964 года насчитывал 500 человек, что явно было недостаточно для одновременного комплексного строительства промышленных, социально-бытовых и жилищных объектов. Для решения поставленных задач ему необходимо было ещё столько же работников (33).

Кадровый дефицит на строительных предприятиях области носил хронический характер. По состоянию на 1 мая 1959 года на предприятиях строительных материалов Западно-Сибирского совнархоза работало всего 1500 человек при дефиците 93 инженеров и техников. Однако по плану в 1960 году предусматривалось направить для работы на север Тюменской области только 17 инженеров и 15 техников (34). 
Состояние трудовой дисциплины на кирпичных и железобетонных заводах было крайне низким. В отдельные дни невыходы на производство составляли до $20 \%$ работающих. Имеющиеся механизмы использовались крайне неудовлетворительно. Из 30 башенных кранов работало $70 \%$ и, как правило, только в одну смену. Экскаваторы использовались на 50\%. В одну смену их них работало 70\%. Всего на 40-49\% были механизированы штукатурные и малярные работы (35).

В начале 1960-х гг., как мы отмечали, у Правительства и Госплана СССР ещё не было полной уверенности в том, что этот регион располагает стратегическими ресурсами углеводородного топлива и сможет составить альтернативу разработанным традиционным месторождениям нефти и газа. В условиях неопределенности и большого риска средства выделялись экономно, практически только на решение ближайших производственных задач.

Становилось очевидным, что в многообразной цепи задач освоения новой нефтегазоносной территории на севере Тюменской области все большую актуальность приобретала проблема формирования в структуре ЗападноСибирского нефтегазового комплекса современной индустриальной строительной отрасли промышленности.

В условиях острейшей потребности технического перевооружения строительной отрасли в Западной Сибири руководство страны предпринимает решительные меры по осуществлению глубоких изменений в региональном управлении строительного производства, отвечающих реальным задачам формирования новой социально-экономической модели края. Совет Министров СССР стремится сконцентрировать на севере Западной Сибири стратегическое управление производством строительных материалов и конструкций для более оптимального осуществления задач обустройства нефтяных и газовых месторождений, капитального и жилищного строительства. Однако, как вспоминал Ю.П. Баталин, стоявший у истоков создания этого управленческого центра, «Главуралстрой», расположенного в Свердловске, в состав которого входили тюменские тресты, при поддержке Свердловского обкома КПСС наотрез отказался развернуть строительные работы на нефтяных месторождениях. «Минтяжстрой», самое сильное в то время союзное строительное министерство, в чью зону входила Тюменская область, также не согласилось сделать это, мотивируя свой отказ задачами по развитию черной металлургии. В чем, кстати, получило поддержку «металлурга» Л.И. Брежнева (36). Поочередно взять на себя ответственность за создание строительной 
индустрии в Западно-Сибирской нефтегазовой провинции отказались «Минтрансстрой» и «Минмонтажнефтестрой» (37).

Предположительно такую реакцию руководителей ведущих отраслей тяжелой индустрии СССР можно объяснить тем, что в тот период мощности строительных организаций нефтяной отрасли страны требовали значительного увеличения для реализации задач, поставленных в решениях руководства партии и правительства. В документах XXIII съезда КПСС предусматривалось выполнение задач пятилетки за счет роста капиталовложений в 1,5 раза (38).

В то же время успешно развивалась газовая промышленность. Решающим организационным фактором ускоренного развития газовой промышленности в первой половине 1960-х гг. явилось то, что в условиях перестройки системы управления народным хозяйством, начавшейся в 1957 году, газостроительные организации после длительной борьбы, в отличие от нефтяных ведомств, не были переданы совнархозам. Нефтестроительные организации в территориальных строительных главках утратили свои ведущие позиции, что отрицательно сказалось в целом на развитии нефтяной промышленности в первой половине 1960-х гг.

В этой ситуации по инициативе Председателя Совета Министров СССР Алексея Николаевича Косыгина при Совмине было создано новое структурное подразделение «Главгаз» во главе с Алексеем Кирилловичем Кортуновым. Под его начало было передано 12 нефтестроительных трестов, после чего он был преобразован в Комитет по газовой промышленности - «Газпром» (39).

Следующим судьбоносным шагом в становлении строительной индустрии ХМАО-Югры стало решение о создании в Тюмени специального главка, наделённого чрезвычайными полномочиями, в задачу которого входило бы формирование в кратчайшие исторические сроки фундамента становления строительной индустрии на территории севера Западной Сибири для обустройства нефтяных и газовых месторождений, а также развёртывание уникального в мировой практике градостроительства в сложных природноклиматических условиях необжитого региона. На основании Распоряжения Совета Министров СССР от 6 февраля 1965 года № 209-р и в соответствии с Приказом Государственного производственного комитета по газовой промышленности СССР от 16 февраля 1965 года № 114 было учреждено «Главное управление по строительству предприятий нефтяной и газовой промышленности в Западной Сибири» с местоположением в г. Тюмени «Главтюменнефтегазстрой» (40). 
Его руководителем был назначен Алексей Сергеевич Барсуков. Он являлся опытным высококвалифицированным специалистом промышленного и гражданского строительства. Участник Великой Отечественной войны, получивший первый орден за инженерное обеспечение танкового прорыва, он хорошо усвоил её уроки. После войны А.С. Барсуков выполнял ответственные государственные задания по вводу в строй знаменитого Новокраматорского машиностроительного завода им. В.И. Ленина. В 1949 году он был назначен управляющим треста «Особстрой», контролируемого лично И.В. Сталиным. Ему было поручено строительство высотных зданий в Москве. Потом были Донбасс, Сумгаит, Волгоград, где он возводил заводы, фабрики, прокатные станы и целые города (41).

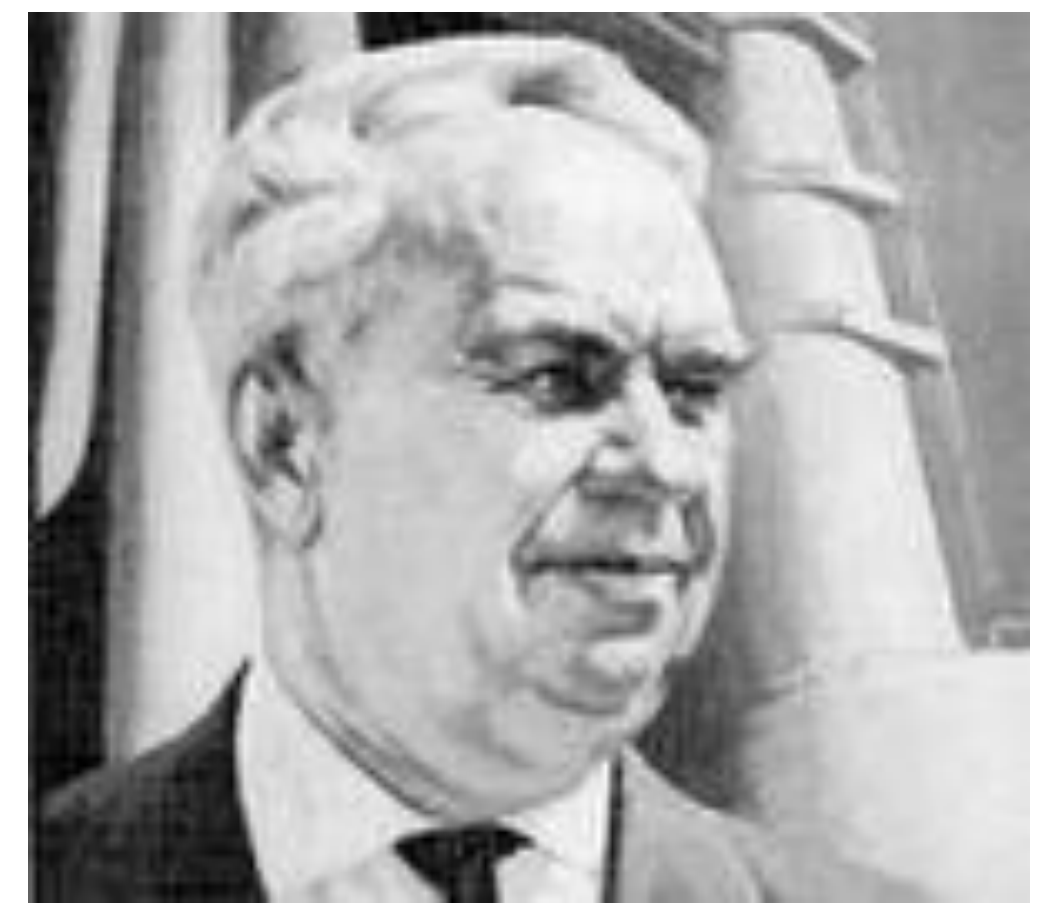

Алексей Сергеевич Барсуков, директор института «Роспроект» (1963-1964), уполномоченный Газпрома СССР по Тюменской области (1964-1965), начальник Главтюменнефтегазстроя (1965-1970)

Ещё до принятия Советом Министров СССР официального решения о создании «Главтюменнефтегазстроя», в октябре 1964 года, А.С. Барсуков был назначен специальным уполномоченным Комитета газовой промышленности СССР с задачей создать в Тюмени новый главк с целью материально- 
технического обустройство нефтяных и газовых месторождений, строительства новых посёлков и городов, создания социально-культурной инфраструктуры на территории новой нефтяной провинции страны (42).

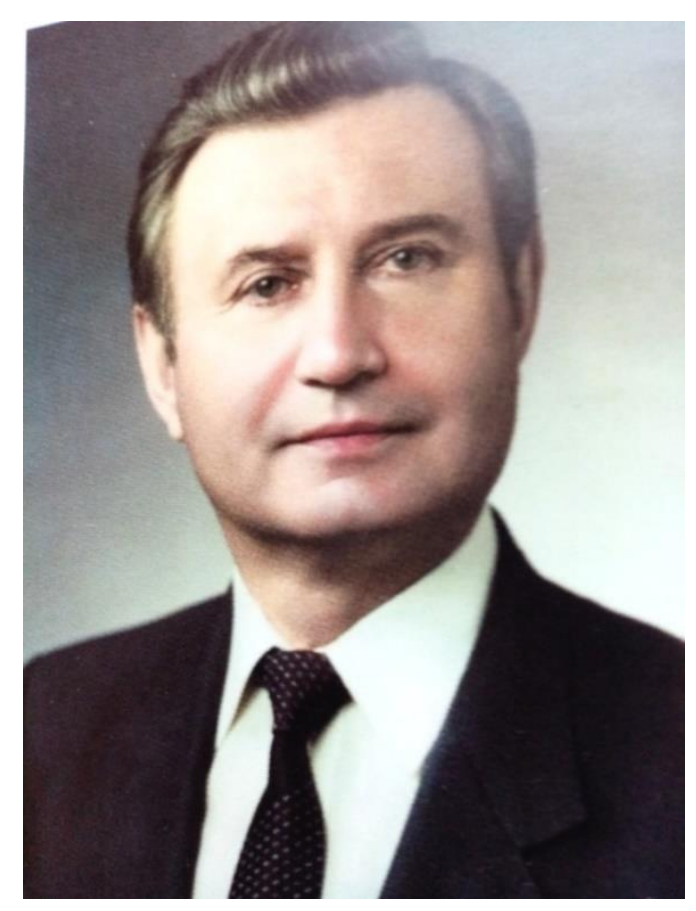

Юрий Петрович Баталин, одновременно главный инженер и первый заместитель начальника Главтюменнефтегазстроя (1965-1970), заместитель министра газовой промышленности (1970-1972), первый заместитель Министра строительства предприятия нефтяной и газовой промышленности (1973-1984), заместитель Председателя Совета министров СССР (1985-1989)

Свою «ознакомительную поездку» в 1964 году он начал с посещения Тюмени и Сургута, о которой позже вспоминал: «Я приехал в Тюмень в мае 1964 г. Там ничего не было. Ни-че-го. Есть такой город Сургут. Там было три лошади и один самосвал...» (43).

Надёжным соратником А.С.Барсукова стал многое воспринявший от него переведенный из Башкирии на должность главного инженера главка Юрий Петрович Баталин, будущий заместитель председателя Совета Министров СССР и одновременно Председатель Госстроя страны в непростые 1980-е гг. Молодой Ю.П. Баталин и зрелый А.С. Барсуков, разные по характеру, взрывной Ю.П. Баталин и спокойный, основательный А.С. Барсуков, удачно дополняли 
друг друга в процессе формирования структуры нового главка и системы его управления.

Новый главк создавался в середине 1960-х гг., когда закладывались основы производственной, технической и социальной политики руководителей главных структурных подразделений формирующегося Западно-Сибирского нефтегазового комплекса и его строительных организаций. Решая эту задачу со свойственной ему энергией, Барсуков сформировал оперативную группу из пяти человек, представителей Москвы, Тюмени и Омска. На основании Распоряжения Совета Министров СССР от 6 февраля 1965 года № 209-р и в соответствии с Приказом Государственного производственного комитета по газовой промышленности СССР от 16 февраля 1965 года № 114 было организовано хозрасчетное предприятие «Главное управление по строительству предприятий нефтяной и газовой промышленности в Западной Сибири» «Главтюменнефтегазстрой» с местоположением в городе Тюмени (44).

В его состав первоначально вошли ряд структур треста «Тюменнефтегазпроводстроя»: Строительное управление № 8 в г. Тюмени, Строительное управление № 9 в г. Сургуте, Строительное управление № 10 в г. Усть-Балыке, Строительное управление № 11 в г. Мегионе, Строительное управление № 14 в г. Нижневартовске, Специальное управление по сантехническим работам в г. Тюмени, Спецучасток сантехнических работ в г. Сургуте, База комплектации и снабжения с перевалочными пунктами в Омске, Сургуте, Нижневартовске, Нефтеюганске и Тюмени, Автотранспортная контора № 2 с подчиненными автобазами № 4, 6, 8 в Сургуте, Усть-Балыке и Мегионе, учебно-курсовой комбинат в г. Сургуте, Нормативноисследовательская станция в г. Сургуте.

В структуре «Главтюменнефтегазстроя» был организован новый трест по комплектации и материально-техническому снабжению с местоположением в г. Тюмени. Ему в подчинение были переданы контора материально-технического снабжения в г. Новосибирске, база комплектации и снабжения в г. Тюмени и перевалочная база в г. Тавде. В том же году в г. Тюмени был создан еще один производственный трест создающегося гигантского главка - трест автомобильного и водного транспорта (45).

В самые короткие сроки под руководством его начальника, талантливого организатора строительного производства Алексея Сергеевича Барсукова, была сформирована организационная структура нового главка, наделенного чрезвычайными полномочиями. В 1970 году Главк насчитывал уже 4000 
человек руководящего управленческого состава, сформированного из числа 18000 специалистов, прошедших «школу А.С. Барсукова», которого коллеги уважительно называли «дед». 14000 человек не справились с поставленными задачами - ушли или были уволены (46). Позже Алексей Сергеевич вспоминал: «Я в Тюмени прожил около 7 лет. Когда оттуда уходил, это было в семидесятом году, то оставил двенадцать трестов, тридцать пять тысяч человек. Хозяйство огромное. Тюмень есть Тюмень. Ох, какая это была работа! Страшно просто...» (47).

В процессе интенсивного расширения объемов капитального и жилищного строительства им продолжался непрерывный поиск оптимальной модели системы управления промышленного и жилищного строительства в Западной Сибири. На основании Приказа Миннефтегазстроя СССР от 12 февраля 1966 года «О структурных изменениях в составе «Главтюменнефтегазстроя» СУ № 6 в Тюмени было реорганизовано в трест «Тюменьгазстрой», СУ-9 в Сургуте - в трест «Сургутгазстрой», СУ-12 в Урае в трест «Шаимгазстрой», СУ-14 в Нижневартовске - в трест «Мегионгазстрой», Хозрасчетный участок строительных работ в Урае СУ-12- в СУ № 6 треста «Шаимгазстрой». В составе главка дополнительно был создан трест специализированных работ «Спецгазстрой» с дислокацией в Тюмени. На основании Приказа Мингазстроя СССР от 9 декабря 1966 года также были созданы тресты «Нефтеюганскгазстрой» и «Ямалгазстрой», а в 1967 году трест «Тюменнефтегазмеханизация». В 1969 году были организованы тресты «Тюменьгазмонтаж» и «Севергазстрой» (48).

В ходе дискуссии того времени о путях организации промышленного освоения новой нефтегазоносной территории и формах расселения трудовых ресурсов, преимуществах и недостатках создания региональных материальнотехнических баз, сети межобластного снабжения, организации промышленной эксплуатации и обустройства месторождений А.С. Барсуков подчеркивал необходимость создания производственных баз на начальном этапе строительства Западно-Сибирского нефтегазового комплекса. В июне 1965 года на пленуме Тюменского областного комитета КПСС А.С. Барсуков, опираясь на мнение рабочих, уверенно заявлял: «Базы - это основа плодотворной работы, это начало начал!». Он выражал неудовлетворение тем, что строительные организации «Главтюменнефтегазстроя» не вели в первые пять месяцев текущего года строительство первоочередных объектов производственных баз бурения, энергопоездов и промысла геофизики в Урае, Сургуте и 
Нефтеюганске. Он выражал большую обеспокоенность тем, что «в текущем году не на все базы предусмотрено выделение необходимых финансовых средств». «Мы, например, ничего не строим из баз заказчику в Урае, то же и в Сургуте»,- с горечью констатировал он (49).

Актуальность создания баз стройиндустрии в Западной Сибири А.С. Барсуков связывал с опасным, по его мнению, форсированием темпа и объёмов нефтедобычи. Программа работ только для собственных подразделений главка составила в 1966 году 98 млн. руб. «Можем ли мы поднять эту программу?» - обращался он с далеко не риторическим вопросом к залу на пленуме Тюменского обкома КПСС в июне 1965 года.

Отвечая на него, он разъяснял: «Для этого надо 2000-2200 автомобилей, 120-140 бульдозеров, 100-120 единиц экскаваторов, а мы имеем только 25\% от их количества. И самое главное, для того чтобы ее выполнить, нужно по подсчетам специалистов Главка 16-18 тыс. рабочих» (50).

По мнению А.С. Барсукова, существовало два пути развития ЗападноСибирского нефтегазового комплекса. Первый путь он называл «программаминимум», и заключалась она в том, чтобы «на 1,5-2 года отказаться от многого и оставить только самое необходимое для добычи нефти». Создав запас скважин в Сургуте и Усть-Балыке, он полагал возможным «сократить капиталовложения и перебросить их на строительство промышленных баз. А за это время будет построен нефтепровод Усть-Балык - Омск, который быстро восполнит недоданную нефть, резко удешевит стоимость нефти и окупит затраты на предлагаемые мероприятия...» (51).

Обосновывая необходимость первого пути, Алексей Сергеевич говорил: «Институтами подсчитано и спрогнозировано, что для того чтобы добыть и передать на переработку 70 миллионов тонн нефти к 1975 году и довести добычу до 200 миллионов тонн к 1980 году, нужно затратить до 4 миллиардов рублей, нужно привлечь для этого сотни тысяч человек населения.» Это целесообразно ещё и потому, подчеркивал А.С. Барсуков, что освоение природных ресурсов нашей области усложняется суровыми климатическими условиями, отсутствием транспортных связей, кроме рек, эксплуатация которых продолжается всего 4-4,5 месяца в году.

Второй путь А.С. Барсуков ассоциировал с» программой максимум». «Для её выполнения нужно дать средства и материальные ресурсы, механизмы и оборудование и идти развёрнутым фронтом... Для этого нужно, чтобы 
тюменской целине отдавалось столько и так, как это делалось, скажем, на строительстве Братской или Волгоградской ГЭС», - утверждал он (52).

Сегодня, по прошествии многих лет, невольно задумываешься о причинах его командировки в Ирак в 1970 году. Почему он, проработав там до 1976 года в качестве главного советского специалиста на нефтепромыслах «Северная Румейла», был удостоен высшей награды Ирака - Ордена Двуречья, а в своей стране среди отмеченных Звездою Героя Социалистического Труда заслуженных организаторов геологоразведочного, нефтегазового, энергетического, транспортного производств тех эпохальных лет нет главного создателя необходимых условий для их функционирования - главного строителя Западно-Сибирского нефтегазового комплекса Алексея Сергеевича Барсукова?

Выражая уверенность в справедливости своих рассуждений, он продолжал концентрировать железобетонное производство на комплексных промышленных базах, прилагая усилия приблизить к непосредственному производству все технологические циклы строительства, в том числе и насыщенное механизмами производство кирпича. В процессе этого им была выдвинута и частично реализована оригинальная плодотворная идея передвижных кирпичных заводов (53).

Партийные, советские и хозяйственные руководители Тюменской области с пониманием относились к инициативам А.С. Барсукова и активно работали над реализацией многих из них. В совместном Постановлении Тюменского обкома КПСС и исполкома областного Совета депутатов трудящихся 15 августа 1967 года самокритично отмечается, что производство строительных материалов в области резко отстает от роста объемов капитальных вложений и сдерживает темпы строительства производственных и культурно-бытовых объектов. В 1967 году недостаток стеновых материалов составил 150 млн. штук условного кирпича. Обком КПСС и Областной исполнительный комитет принимают решение увеличить к 1971 году их производство до 750 млн. штук условного кирпича и утверждают задания по вводу новых и реконструкции действующих предприятий железобетонных изделий.

Принятая программа создания и реконструкции предприятий строительной индустрии в новой нефтегазоносной провинции, хотя и с нарушениями намеченных сроков, но последовательно выполнялась. Уже в 1969 году «Главтюменнефтегазстрой» сдал в эксплуатацию первую очередь 
Тюменского домостроительного комбината, а в четвертом квартале 1970 года первую очередь Сургутского домостроительного комбината (54).

Обращает на себя внимание интенсивность и масштабы строительства предприятий строительной индустрии непосредственно в новых городах ХМАО-Югры как средство реализации строительной политики А.С. Барсукова и Ю.П. Баталина, направленной на приближение производственных баз непосредственно к строительным площадкам и уменьшение тем самым зависимости регионального градостроения от ведомственных и федеральных поставок конструкционных материалов.

В этом отношении наглядным примером решения такой задачи, существенно снизившим инъекцирование сибирского градостроения ведомственными элементами жилищного строительства города Нижевартовска и способствовавшим концентрации производственных процессов его застройки, стало создание в городе в 1979 г. собственного домостроительного комбината. Он выпускал и монтировал жилые дома из крупнопанельных блоков собственного производственного строительно-монтажного объединения «Нижневартовскстрой» Главтюменростроя министерства промышленного строительства СССР. В 1986 году это предприятие становится трестом крупнопанельного домостроения, а в 1988 году - проектно-строительным объединением крупнопанельного домостроения «Нижневартовскжилстрой» территориальноного строительного объединения «Тюменьстрой» Минуралсибстроя. Впоследствии, занимаясь выпуском и монтажом жилых домов из крупнопанельных элементов, этот «концерн» представлял собой объединение предприятий «Нижневартовскжилстрой» ассоциации «Нижневартовскстрой» Минуралсибстроя (55). Сердцевиной Нижневартовского домостроительного комбината являлся созданный в 1979 году завод крупнопанельного домостроения. Он занимался производством и реализацией деталей крупнопанельного домостроения, железобетонных изделий, строительно-монтажными и ремонтно-строительными работами до прекращения своей деятельности в 1999 году (56).

Быстрыми темпами вводились в эксплуатацию и другие предприятия строительной индустрии непосредственно в городах округа. В конце 1960-х1970-х гг. наряду с указанными домостроительным предприятиями Нижневартовска, несмотря на существенные проблемы и трудности производственной деятельности, в Сургуте были построены 4 завода, которые 
реально выдавали промышленную продукцию, заводы крупного домостроения, железобетонных изделий, керамзита и товарного бетона (57).

Особенно убедительным в утверждении о том, что «западно-Сибирский нефтегазовый комплекс и города ХМАО-Югры строила вся страна» является активное участие в этом Всесоюзном действии непосредственно Тюменской области, географически расположенной ближе всех к входящей в его состав областей. В Тюмени было возведено два мощных завода крупнопанельного домостроения, заводы комплектно-блочных устройств и ремонта машин и механизмов, цех стеклопрофилита и мозаичный плитки, в п. Локосово и п. Советском было построено 2 кирпичных завода, в п. Богандинском - завод по производству керамзитового гравия, Для обеспечения строящихся объектов ХМАО-Югры исключительно важную роль играл ввод в эксплуатацию в 1971 году в посёлке Харп дробильно-сортировочной фабрики по производству щебня, одновременно вводились в строй и другие, менее мощные, предприятия различной ведомственной принадлежности (58).

Прозорливая строительная политика А.С. Барсукова и Ю.П. Баталина позволила «Главтюменнефтегазстрою» ежегодно перевыполнять план и наращивать объемы строительно-монтажных работ. Заметное увеличение числа действующих кирпичных предприятий не только расширяло масштабы производства кирпича в том виде, в каком он производился раньше, но и сопровождалось внедрением новой технологии массового выпуска крупных кирпичных блоков, В 1960-е гг. второе рождение получил ставший одним из крупнейших в области кирпичный завод «Труд» Управления промышленности стройматериалов, возводимый трестом «Тюменьоблстрой». В их числе значились такие крупные кирпичные предприятия, как Богандинский кирпичный завод треста «Облммежколхозстрой», кирпичный завод треста «Тюменьлесстрой», с выпуском каждым из них по 40 млн. штук условного кирпича в год. Решающую роль в их строительстве играл трест «Тюменьоблстрой». Главк «Главтюменнефтегазстрой», осуществляя координацию их строительства, заложил фундамент собственного кирпичного завода с мощностью годового производства 16 млн. штук условного кирпича. Одновременно, реализуя стратегическую задачу А.С. Барсукова приближения материальной базы строительства к производству, главк начал осуществлять оригинальную идею «передвижных кирпичных заводов».

Предприятия строительной индустрии ХМАО-Югры и Тюменской области становились самодостаточным субъектом производства строительных 
материалов и стеновых конструкций. При этом в ходе создания новых заводов и реконструкции ранее существовавшего производства строительных материалов существенно возрастал объем выпускаемой продукции и обновлялся её ассортимент. Например, поиск оптимальной организации управления и производства упомянутого нами, существовавшего еще до Октябрьской революции, национализированного в 1917 году ветерана строительного производства Западной Сибирикирпичного завода «Труд» завершился преобразованием ТПКО «Тюменьстройматериалов» в товарищество с ограниченной ответственностью (ТОО) «Комбинат строительных материалов», а в апреле 1997 года на его основе было создано открытое акционерное общество (ОАО) «Комбинат строительных материалов (59).

В настоящее время Тюменский комбинат строительных материалов представляет собой современное производство, выпускающее свыше 300 наименований железобетонных изделий, включающих многопустотные плиты перекрытий шириной 1,5 м, лестничные ступени, марши и площадки, перемычки и прогоны, фундаментные блоки, плиты и ленточные фундаменты, приставки для опор ЛЭП и другие важнейшие строительные конструктивные элементы. На производстве железобетонных изделий и бетона используются только высококачественные материалы. Их высокое качество обеспечивается благодаря входному контролю содержания поступающих цемента, щебня, песка, химических добавок, металла, а также контролю качества производимых железобетонных изделий на всех этапах производства, включая проверку уже готовой продукции (60).

Крупные задачи в ходе эволюции своего производства решал трудовой коллектив Винзилинского завода силикатных изделий. Отметив в предыдущей главе его стремительную эволюцию в 1965-1967 гг. как производителя кирпича, обратим внимание на развитие индустриального потенциала этого предприятия и его вклад в технологическую трансформацию строительной отрасли Западной Сибири в последующие годы.

В 1973 году Всесоюзным государственным институтом по проектированию предприятий промышленности строительных материалов «НИИКерамзит» был разработан проект строительства завода керамзитового гравия. На основе этого проекта работы по строительству завода в п. Винзили (Тюменская область) были начаты в апреле 1976 года и завершены в декабре 1980 года. Свой двадцатилетний юбилей в 1985 году Винзилинский завод 
силикатных изделий знаменовал выпуском 2 млрд. 100 млн. штук силикатного кирпича и 240 тыс. кв.м. облицовочной плитки. Переход к рыночной экономике Винзилинский завод осуществлял болезненно. В ходе реорганизации административной системы управления, обновления руководящего кадрового состава и большой части управленцев среднего звена произошел спад производства и строительной активности предприятия, начался переход на бартерные сделки.

Заводу удалось сохранить динамику производства и выйти на высокие экономические показатели. Успешно реализуя предоставленную свободу внешнеэкономиоческих связей, инициативному руководству модернизирующегося предприятия в декабре 2002 года удалось приобрести прессовое оборудование немецкой фирмы «Боймер и Боймер». Первая партия кирпича с этой линии сошла 1 апреля 2003 года, и он сразу завоевал строительный рынок благодаря улучшенным физико-техническим качествам и идеальной геометрии.

Значительному увеличению выпуска строительного кирпича способствовал также ввод в эксплуатацию в марте 2005 года второй очереди пресса БСП-600. Это позволило значительно увеличить выпуск силикатного кирпича по немецкой технологии, значительно расширить ассортимент выпускаемой продукции и запустить в апреле 2009 года линию рустированного кирпича, а в июле - производство известняковой муки для сельского хозяйства(61).

Основным видом деятельности ООО «ВЗКГ» является производство керамзитового гравия из экологически чистой голубой глины Кыштырлинского месторождения, расположенного в 12 км от промплощадки завода. В 2008 году на предприятии начала осуществляться программа диверсификации, в ходе которой завод освоил масштабное производство керамзитобетонных блоков, стеновых и перегородочных, керамзитополистиролбетонных блоков крупного формата, конструкционно-теплоизоляционных для малоэтажного и монолитнокаркасного домостроения, «теплых» перемычек из керамзитополистиролбетона для всех видов строительства, металлической кладочной сетки различных типоразмеров, элементов благоустройства, плитки тротуарной, бордюров, сливов и др., плитки фасадной и облицовочной для наружной и внутренней отделки, фундаментных блоков из керамзитобетона («теплый» подвал) для малоэтажного строительства, художественную ковку из металла.

Керамзитобетонный блок ООО "ВЗКГ" как стеновой материал, разработанный по программе энергосбережения, получил заслуженное 
признание у строителей и проектировщиков, отмечен наградами выставок в Новом Уренгое и Сургуте.

Низкая теплопроводность и водопоглощение, высокая конструкционная прочность и экологическая чистота являются объективными характеристиками данного продукта. Керамзитоблоки ООО "ВЗКГ" представляют собой лучший стеновой материал для строительства частного дома как по цене, так и по качеству. Керамзит Винзилинского комбината применяется для заливки больших керамзитобетонных плит, которые в дальнейшем использовались в многоэтажном строительстве. Также керамзит является отличным утеплителем полов и потолков жилых зданий. Керамзитоблоки всех размеров и видов нашего завода ВЗКГ применяются как в частном домостроении, так и в многоэтажном. Ассортимент керамзитоблоков на заводе огромный и включает в себя такие виды, как стеновые, перегородочные, вентиляционные, полнотелые, фундаментные и пазогребневые. Мощности завода позволяют обеспечить данным строительным материалом потребности строительной отрасли близлежащих районов области. Наличие вблизи завода автомобильных дорог, железнодорожных подъездных путей делает работу завода технически удобной и экономически выгодной для покупателя. В пункты, удаленные от железнодорожных станций, продукция может быть доставлена водным транспортом через порты Тюмень и Тобольск. По дополнительным соглашениям с покупателем завод осуществляет поставки по месту требования. Возможна доставка автомобильным, железнодорожным и речным транспортом по России и за рубеж. Продукция завода является победителем конкурса «Лучшие товары и услуги Тюменской области 2017», включена в Национальный Реестр, в «Перечень 100 лучших товаров России 2017 года», имеет свой товарный знак (62).

30 декабря 1971 года в Тюмени начал функционировать завод ЖБИ-3 как экспериментальный завод, построенный по специальному проекту, разработанному Куйбышевским государственным проектным институтом «Гипронефтестрой» в целях выполнения Постановления Совета Министров СССР по ускоренному развитию Западно-Сибирского топливноэнергетического комплекса. Его современная производственная мощность выпуска железобетонных изделий была рассчитана на 108,5 тыс. куб.м в год. В проект завода была заложена широкая номенклатура выпускаемых изделий, включавшая железобетонные блоки для строительства жилых домов, объектов 
соцкультбыта, промышленных и предназначенных для сельского хозяйства зданий, производства доборных изделий.

Трудно переоценить экономический вклад завода и его правопреемника современного ООО «Завод ЖБИ-3» в городское строительство ХМАО-Югры и всего тюменского региона, осуществленный им в ходе его пятидесятилетней деятельности. Возведенные за полувековую историю жилые микрорайоны и ряд знаковых городских объектов округа являются убедительным свидетельством этого (63).

Заметный след в истории городского строительства ХМАО-Югры оставил Ялуторовский завод стеновых материалов. Продолжая изложение его истории, начавшейся, как мы отмечали, производством кирпича еще в 1971 году, особо укажем, что он впоследствии стал основой современного холдинга «Поревит» - модернизированного предприятия по производству стеновых блоков из автоклавного газобетона, силикатного кирпича и силикатных пазогребневых блоков в Урало-Западносибирском регионе. Его открытие состоялось 22 апреля 2009 года. Производственная мощность завода составляет 300 тыс. м газобетона и 110 млн. штук условного кирпича в год. Завод оснащен автоматизированными линиями производства немецкой фирмы MASA HENKE MaschinenfabrikGmbH.

Для реализации этого проекта была выбрана производственная площадка Ялуторовского «Комбината строительных материалов» площадью 16,8 гектаров, находившаяся на северо-западной окраине Ялуторовска в 75 км от Тюмени. Место расположения было обусловлено близостью сырьевой базы, железнодорожных путей и автомобильной развязки. Наличие собственного карьера песка, обладающего уникальными свойствами, позволяет добиваться исключительной чистоты и стабильности качества строительных материалов завода «Поревит». Его продукция является победителем конкурса «Лучшие товары и услуги Тюменской области 2015, 2016, 2017 гг.». Системный аудит промышленной продукции «Поревита» признал ее соответствующей международному стандарту ECOMATERIA (64).

В добавление к названным предприятиям строительной индустрии, расположенным непосредственно на территории ХМАО-Югры, обратим внимание на то, что, кроме них, градостроение округа имело возможность пользоваться выпуском строительного кирпича еще четырех крупных современных промышленных предприятий, расположенных на территории Тюменской области, включающих ЗАО «Богандинский кирпичный завод», 
ООО «Винзилинский завод строительных материалов», ООО «Инвест-силикатстройсервис», АО «Завод стеновых материалов «Поревит» (65).

Выпуск железобетонных конструкций и изделий на территории Тюменской области осуществляли 13 крупных промышленных предприятий, представленных ООО «Дорстрой-инвест», расположенном в г. Ишиме, ООО «Завод ЖБИ-3» с местоположением в Тюмени, ООО «Завод ЖБИ 5», дислоцированном в Тюмени, ЗАО «Заводоуковский КСМ» (г. Заводоуковск); ООО «Завод железобетонных изделий № 4» (г. Тобольск); ЗАО МПКФ «Алькор» (г. Тюмень); филиал АО «Мостострой-11» (г. Тюмень), ТФ «Мостоотряд-36» (г. Тюмень); филиал АО «Мостострой-11»; ТФ «Мостоотряд87» (г. Тобольск); ООО «СтройТрансИндустрия» (г. Тюмень); ЗАО «ТКСМ» (г. Тюмень); ОАО «ТДСК» (г. Тюмень); ОАО «Тюменский завод ЖБИ-1» (г. Тюмень); ООО «ЖБИ-Промжелдортранс» (г. Тюмень).

В целом предприятиями строительной промышленности Тюменской области в 2017 году было выпущено 144,71 млн. штук условного строительного кирпича и 481,2 тыс. м³ сборных железобетонных конструкций и деталей (66).

Сегодня строительная промышленность Тюменской области, включая предприятия ХМАО-Югры, производит подавляющую часть строительных материалов и удовлетворяет значительную часть потребностей северных территорий Западной Сибири в ее продукции (67).

Таким образом, в процессе производственного и социального становления Западно - Сибирской нефтегазоносной провинции трудовым коллективам предприятий промышленного производства материалов ХМАО-Югры и Тюменской области, несмотря на огромные трудности их организационного, производственного и социального развития, удалось обеспечить капитальное и жилищное строительство крупнейшего в стране нефтегазоносного региона необходимым сырьем и материалами, а в последующие годы заметно приумножить объемы их производства.

В исследуемый период на севере Тюменской области были построены заводы строительной индустрии, обеспечившие, наряду с промышленным, городское освоение северных территорий Западной Сибири. В ХМАО-Югре в 1965-1996 гг. было построено 15 городов, хронология возникновения которых отражена в таблице № 6 (68). Всего на севере Западной Сибири за годы ее нефтегазового освоения был построен 21 город (69). 
Таблица № 6

Населенные пункты, получившие статус города в 1965-1996 гг.

\begin{tabular}{|c|c|c|c|c|c|c|c|}
\hline № & Название & $\begin{array}{c}\text { Район / город } \\
\text { окружного } \\
\text { значения [3] }\end{array}$ & $\begin{array}{c}\text { Муниципальный } \\
\text { район/ городской } \\
\text { округ [4] }\end{array}$ & $\begin{array}{l}\text { Населе- } \\
\text { ние } \\
\text { (чел.) }\end{array}$ & $\begin{array}{c}\text { Основание/ } \\
\text { первое } \\
\text { упоминание }\end{array}$ & $\begin{array}{l}\text { Статус } \\
\text { города }\end{array}$ & Герб \\
\hline 1 & Белоярский & $\begin{array}{c}\text { город } \\
\text { Белоярский }\end{array}$ & $\begin{array}{l}\text { Белоярский } \\
\text { мун.район }\end{array}$ & $\begin{array}{c}\lambda 19622 \\
{[2]}\end{array}$ & 1969 & 1988 & \\
\hline 2 & Когалым & $\begin{array}{c}\text { город } \\
\text { Когалым }\end{array}$ & город Когалым, ГО & $\begin{array}{c}\lambda 67727 \\
{[2]}\end{array}$ & 1975 & 1985 & \\
\hline 3 & Лангепас & $\begin{array}{c}\text { город } \\
\text { Лангепас }\end{array}$ & город Лангепас, ГО & $\begin{array}{c}\nearrow 44646 \\
{[2]}\end{array}$ & 1980 & 1985 & \\
\hline 4 & Лянтор & $\begin{array}{l}\text { Сургутский } \\
\text { район }\end{array}$ & $\begin{array}{l}\text { Сургутский } \\
\text { мун.район }\end{array}$ & $\begin{array}{c}\nearrow 41199 \\
{[2]}\end{array}$ & 1932 & 1992 & \\
\hline 5 & Мегион & город Мегион & город Мегион, ГО & $\begin{array}{c}\searrow 46643 \\
{[2]}\end{array}$ & 1810 & 1980 & \\
\hline 6 & $\begin{array}{l}\text { Нефтею- } \\
\text { ганск }\end{array}$ & $\begin{array}{c}\text { город } \\
\text { Нефтеюганск }\end{array}$ & $\begin{array}{c}\text { город Нефтеюганск, } \\
\text { ГО }\end{array}$ & $\begin{array}{c}\searrow 127255 \\
{[2]}\end{array}$ & 1961 & 1967 & \\
\hline 7 & $\begin{array}{l}\text { Нижневар- } \\
\text { товск }\end{array}$ & $\begin{array}{c}\text { город } \\
\text { Нижневар- } \\
\text { товск }\end{array}$ & $\begin{array}{c}\text { город } \\
\text { Нижневартовск, ГО }\end{array}$ & $\begin{array}{c}7277668 \\
{[2]}\end{array}$ & 1909 & 1972 & \\
\hline 8 & Нягань & город Нягань & город Нягань, ГО & $\begin{array}{c}758565 \\
{[2]}\end{array}$ & 1965 & 1985 & \\
\hline 9 & Покачи & город Покачи & город Покачи, ГО & $\begin{array}{c}\nearrow 18074 \\
{[2]}\end{array}$ & 1984 & 1992 & \\
\hline 10 & Пыть-Ях & $\begin{array}{l}\text { город Пыть- } \\
\text { Ях }\end{array}$ & город Пыть-Ях, ГО & $\begin{array}{c}\searrow 39570 \\
{[2]}\end{array}$ & 1968 & 1990 & \\
\hline 11 & Радужный & $\begin{array}{c}\text { город } \\
\text { Радужный }\end{array}$ & город Радужный, ГО & $\begin{array}{c}\searrow 43666 \\
{[2]}\end{array}$ & 1973 & 1985 & \\
\hline 12 & Советский & $\begin{array}{l}\text { Советский } \\
\text { район }\end{array}$ & Советский мун.район & $\begin{array}{c}\searrow 29293 \\
{[2]}\end{array}$ & 1963 & 1996 & \\
\hline 13 & Сургут & город Сургут & город Сургут, ГО & $\begin{array}{c}7380632 \\
{[2]}\end{array}$ & 1594 & 1965 & \\
\hline 14 & Урай & город Урай & город Урай, ГО & $\begin{array}{c}\lambda 40537 \\
{[2]}\end{array}$ & 1922 & 1965 & \\
\hline 15 & Югорск & город Югорск & город Югорск & $\begin{array}{c}\nearrow 37966 \\
{[2]}\end{array}$ & 1962 & 1992 & \\
\hline
\end{tabular}


В ходе городского строительства степень урбанизации Тюменской области возросла с 32\% в 1960 году до 79,9\% в 2018 году. В ХМАО-Югре этот процесс развивался еще более интенсивно. В 2018 году в городах округа проживало 91,8\% его населения (71).

Возвращаясь к середине 1960-х гг., укажем, что, развивая индустриальную базу севера Западной Сибири, «Главтюменнефтегазстрой» во главе с А.С. Барсуковым пристальное внимание уделял укреплению производственного потенциала непосредственно региональных строительных организаций. Имена рядовых подвижников сибирского градостроения достойны особенно высокой оценки за их вклад в обеспечение на местах необходимых материально-технических и психологических условий формирования современной строительной отрасли в ХМАО-Югре.

В Сургуте у истоков рождения региональной базы строительства стоял А.Г. Кошман, возглавлявший Строительное управление № 9. Уже в октябре 1964 года СУ-9 в условиях острой нехватки арматуры, металла, электродов и других необходимых материалов приступило к монтажу поступивших сборных зданий РММ площадью 576 м $^{2}$ и двух мастерских, соответственно размером

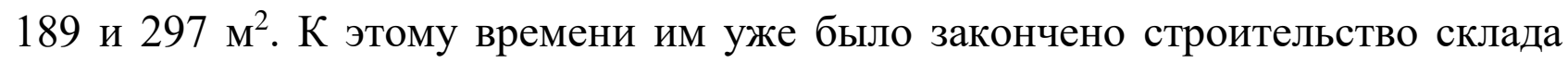
цемента общей площадью $900 \mathrm{~m}^{2}$. Динамика создания производственной строительной базы в Сургуте представлена в таблице № 7 (72).

Таблица № 7

Создание строительной базы в Сургуте (тыс. руб.)

\begin{tabular}{|l|c|c|c|}
\hline \multicolumn{1}{|c|}{ Наименование объекта } & $\begin{array}{c}\text { Начало. Год } \\
\text { строительства, } \\
\text { год }\end{array}$ & $\begin{array}{c}\text { Сметная } \\
\text { стоимость, } \\
\text { тыс. руб. }\end{array}$ & $\begin{array}{c}\text { Всего стр- } \\
\text { монтаж. работ работы, } \\
\text { тыс. руб. }\end{array}$ \\
\hline Подготовка территории базы & 1965 & 2,3 & 2,3 \\
\hline Профилакторий & 1965 & 79,4 & 79,5 \\
\hline Авторемонтная мастерская & 1965 & 100,1 & М \\
\hline Моечная эстакада & 1965 & 19,1 \\
\hline Сантехническая мастерская & 1965 & 19,8 & 14,9 \\
\hline Электроремонтная мастерская & 1965 & 208,6 & 144,7 \\
\hline Производственный корпус РБХ & 1965 & 69,4 & 37,2 \\
\hline Пропарочные камеры полигона ЖБИ & 1965 & 39,2 & 33,6 \\
\hline Арматурная мастерская & 1965 & 1,6 & 1,6 \\
\hline Подкрановые пути & 1965 & 283,3 & 283,3 \\
\hline Производственные и складские площадки & 1965 & 148,9 & 148,9 \\
\hline Автопроезды & 1965 & & 15,2 \\
\hline
\end{tabular}


ГОРОДСКОЕ СТРОИТЕЛЬСТВО В ХАНТЫ-МАНСИЙСКОМ АВТОНОМНОМ ОКРУГЕ - ЮГРЕ (к.1950-х - сер.1990-х г2.)

\begin{tabular}{|l|c|c|c|}
\hline Вертикальная планировка & 1965 & 16,5 & 16,5 \\
\hline Материальные склады & 1965 & 27,2 & 27.2 \\
\hline Склад оборудования & 1965 & 14,4 & 14,4 \\
\hline Склад карбида и кислорода & 1965 & 9,2 & 9,2 \\
\hline Склад битума & 1965 & 7,8 & 7,8 \\
\hline Склад ГСМ & 1965 & 16,4 & 13,6 \\
\hline Склад тарного цемента & 1965 & 29,8 & 29,8 \\
\hline Водоснабжение & 1965 & 28,8 & 28,8 \\
\hline Временные причалы & 1965 & 275,7 & 235,3 \\
\hline Электроснабжение & 1965 & 15,1 & 15,1 \\
\hline Теплосети & 1965 & 15,1 & 15,1 \\
\hline Автодороги & 1965 & 61,9 & 61,0 \\
\hline Телефонизация и радиофикация & 1965 & 22,8 & 18,9 \\
\hline Котельная & 1965 & 97,7 & 88,5 \\
\hline Временные здания и сооружения & 1965 & 38,4 & 38,4 \\
\hline Прочие затраты 9,8\% & 1965 & 191,5 & 157,3 \\
\hline Проектные работы & 1965 & 32,9 & \\
\hline Непредвиденные расходы & 1965 & 47,7 & \\
\hline ИТОГО: & & 2005,6 & 1695,8 \\
\hline
\end{tabular}

Данные таблицы свидетельствуют о большом масштабе проводимых руководством СУ-9 работ по созданию собственной производственной базы уже на начальном этапе городской застройки Сургута. Однако, несмотря на энтузиазм региональных градостроителей, их объективные конструктивные технические возможности не соответствовали масштабным задачам строительства многотысячных нефтяных городов. По мере укрепления строительных организаций и расширения масштабов их деятельности Сургут продолжал застраиваться брусовыми домами в двух направлениях - со стороны поселка нефтяников и в промежутке между Старым Сургутом и Черным Мысом, которые через некоторое время слились.

Ввод в эксплуатацию стандартных брусовых домов позволял сургутянам достойно переносить суровые сибирские зимы. Возможно, застройка Сургута еще длительное время осуществлялась бы по этой «проектно-архитектурной модели», но приезжающая молодежь не желала жить в «деревне», а мечтала о современном городе. Поэтому неслучайно одной из наиболее острых проблем, которые тогда обсуждались, была проблема, какими должны создаваться новые города, деревянными или капитальными, «каменными». 
Сторонниками деревянного исполнения городов были подрядчики. Они обосновывали свою точку зрения тем, что населенные пункты Среднего Приобья располагаются в таежной зоне, где много леса, из которого на местах можно изготовлять сборные жилые дома и другие здания и сооружения. Кроме того, как утверждали сторонники этой точки зрения, «здесь нет ни камня, ни гравия, ни глины. Все это необходимо будет завозить за несколько сот километров при отсутствии железнодорожных и автомобильных дорог и короткой речной навигации, что потребует огромных финансовых затрат» (73).

Нефтяники, которые выступали в роли заказчиков, были убеждены, что город надо строить из долговечных и несгораемых материалов. Их главный аргумент, до определенного времени являвшийся дискуссионным и не находившим абсолютной поддержки у высоких руководителей, состоял в том, что нефтяники будут здесь жить и работать сотни лет. Поэтому они должны иметь комфортные и надежные жилые дома и всю социальную инфраструктуру. Оппоненты «вахтового метода» стремились доказать, что каждый квадратный метр территории, отвоеванный у болот, будет стоить огромных денег, поэтому нужно строить многоэтажные дома на свайных основаниях. Немаловажными, на их взгляд, являлись и соображения пожарной безопасности. К тому времени имелись факты выгорания до основания целых деревянных поселков в условиях ветреных широт Среднего Приобья (74).

Дискуссия затягивалась. Отсутствие определенного решения тормозило проектирование Сургута, Урая, Нефтеюганска и Нижневартовска. Все громче звучали призывы к сдерживанию ведущегося в них строительства. В этих условиях заместитель Председателя Совета Министров М.Т. Ефремов после очередного обсуждения у него «градостроительного вопроса Западной Сибири» принял решение ознакомиться с характером городского строительства на аналогичной территории, в зоне вечномерзлых грунтов соседней Финляндии.

В течение недели была сформирована представительная делегация из восьми человек, в которую вошли Ш.С. Донгарян, заместитель министра нефтяной промышленности, Н.Л. Вовченко, заместитель министра газовой промышленности, В.И. Муравленко, начальник «Главтюменнефтегаза», А.С. Барсуков, начальник Главтюменнефтегазстроя, В.Н. Огородников, секретарь Томского обкома КПСС, представители Госстроя и Управления лесной промышленности Тюменской области. Делегация ознакомилась с опытом жилищного строительства в окрестностях г. Хельсинки и г. Оулу, а также северного района Лапландии (75). 
Вернувшись в Москву, все участники командировки выразили уверенность в том, что в Западной Сибири нефтяные города в основном целесообразно застраивать многоэтажными из несгораемых материалов и конструкций домами (76). После решения вопроса застройки городов главку под руководством А.С. Барсукова необходимо было решить, кто будет здесь строить и как.

Однако градостроительная ситуация здесь осложнялась тем, что предыдущий опыт восстановления разрушенных после войны городов, когда многие из них фактически создавались на основе образованных СНиПов и представляли собой идеальный тип рабочих поселков с четким функциональным зонированием и жилыми кварталами, представлявшими равные условия для проживания населения, не годился. По воспоминаниям Ш.С. Донгаряна, в то время заместителя министра нефтяной промышленности СССР, весь 1966 год ушел впустую на поиски возможности привлечь чьи-то силы и приступить к разработке требуемых норм и правил (77).

Освоение уникальных нефтяных и газовых месторождений Западной Сибири требовало проведения в короткие сроки различного строительства, однако чрезвычайно сложные инженерно-геологические условия, вечная мерзлота, сильная заболоченность и крайняя неоднородность грунтов во многом усложняли и затягивали этот процесс. Кроме того, не существовало никакого наработанного материала, который можно было бы положить в основу разработки нормативной документации, государственных и отраслевых стандартов, отражающих разнообразие природно-климатических условий, наличие сырьевых ресурсов для стройиндустрии, состояние технической базы домостроения, ведомственную разобщенность и многое другое, что характеризовало бы региональную специфику гражданского строительства на территории нового освоения. Такие параметры представляли собой исключительную актуальность для разработки и внедрения генеральных схем управления строительством здесь. Изучение инженерно-геологических особенностей строительства в Западной Сибири Госкомитет Совета Министров СССР по науке и технике поручил Производственному и научноисследовательскому институту по инженерным изысканиям в строительстве. С этой целью в Тюмени был создан отдел, а в Салехарде - лаборатория института. Однако, как отмечал секретарь Тюменского обкома КПСС А. Протазанов в служебной записке от 2 июля 1968 года Председателю Государственного комитета Совета Министров СССР по науке и технике Т. Кириллину: 
«Инженерно-геологическая изученность этой территории сильно отстает от темпов строительства. Эти маломощные подразделения не в состоянии справиться с теми задачами».

Поэтому техническая политика в строительстве на севере Сибири складывалась в значительной степени стихийно, по ходу проектирования и сооружения отдельных объектов, без регулирующей основы регионального характера. Новизна и неизученность географических и природноклиматических условий градостроительства на севере Западной Сибири, его номинальное архитектурно-планировочное управление требовали от руководителей строительства нестандартных самостоятельных решений.

В феврале 1967 года министр нефтедобывающей промышленности Д.В. Шашин пригласил в Тюмень около 1000 самых известных проектировщиков, ученых и инженеров-строителей, которые в течение двух недель сформулировали пункты «Временных строительных норм и правил». Через месяц они были утверждены и в течение 20 лет являлись руководством к действию проектировщикам и инженерам, переходя пунктами и частями в основные СНиП (79).

Можно утверждать, что программа гражданского и жилищного строительства на территории Западно-Сибирского нефтегазового комплекса во многом создавалась на базе этих «Временных строительных норм и правил», созданных и утвержденных Миннефтепромом СССР.

Категорическим противником абсолютизации каменного строительства в окруженном лесами Сургуте выступал первый генеральный директор производственного объединения «Сургутнефтегаз» Н.П. Захарченко. На одном из партийных активов он откровенно высказался против такой односторонности в градостроительной политике: «Времена романтики прошли, белокаменные дома красиво смотрятся, но, кроме них, нужны и те, в которых люди будут жить и работать» (80).

Сразу после категорического заявления Н.П. Захарченко на трибуну поднялся первый секретарь Тюменского обкома КПСС Б.Е. Щербина и не менее определенно заявил: «Мы будем строить только белокаменные города, никакого деревянного жилья не будет!» (81).

По воспоминаниям Н.П. Захарченко, дело доходило до абсурда. В середине 1970-х гг. в Сургуте, неподалеку от гостиницы «Северной», стояли 
почти готовые, под крышей, несколько деревянных домов. «Утром, вспоминает генеральный директор, - вижу: два дома разобраны, один так даже сожжен». (82) Этот спор разрешила встреча Н.П. Захарченко с секретарем ЦК КПСС В.И. Долгих, который был крайне удивлен тем, что в Среднем Приобье при богатейших лесных ресурсах запрещено деревянное строительство. Итогом встречи стали отмена этого непродуманною запрета и начало деревянного строительства в Белом Яру и вахтовых поселках.

Отсчет официальной застройки города Сургута, исключая самостоятельно построенный нефтяниками в 1966 году дом на Набережной № 46, крупнопанельными домами начинается в мае 1968 года. Под руководством заместителя начальника производственного отдела Управления строительством Сургутской ГРЭС Алексея Белогорохова была сделана привязка на местности первого крупнопанельного дома в микрорайоне энергегиков (83). В 1969 году «Сургутгазстроем» в городе было построено 4 крупнопанельных пятиэтажных жилых здания сметной стоимостью 8733 рубля, общей площадью 7900 квадратных метров (84). В микрорайоне строителей первое крупнопанельное пятиэтажное здание было построено в 1971 году Строительным управлением № 22 во главе с В.П. Пересыпкиным (85).

Над Обью начинал подниматься новый город. Однако в вопросе о перспективах развития Сургута было много скептиков. Проектировщиков и строителей критиковали в Тюменском обкоме КПСС, Сургутском горкоме партии и даже в центральной печати. В 1976 году газета «Советская Россия» поместила статью под названием «Сургутские хутора», в которой автор эмоционально доказывал утопичность рассуждений о том, что «это» станет городом. Он был убежден в том, что идея единого города обречена на провал (86).

Были «неверующие» и среди самих будущих горожан. В.И. Унжаков вспоминал: «Когда построили пятиэтажный дом на нынешнем проспекте Ленина, заселялись туда неохотно. Ни дорог, ни магазинов, ни школы поблизости. А я тогда говорил: «Ребята, вы будете жить в центре города». Ближайшей к одиноко стоящему дому была улица 50 лет ВЛКСМ. Этот адрес дом и получил. Потом, когда уже вокруг застроился проспект Ленина, на нем красовался дом, на табличке которого оставался еще его исторический адрес «Улица 50 лет ВЛКСМ» (87). 


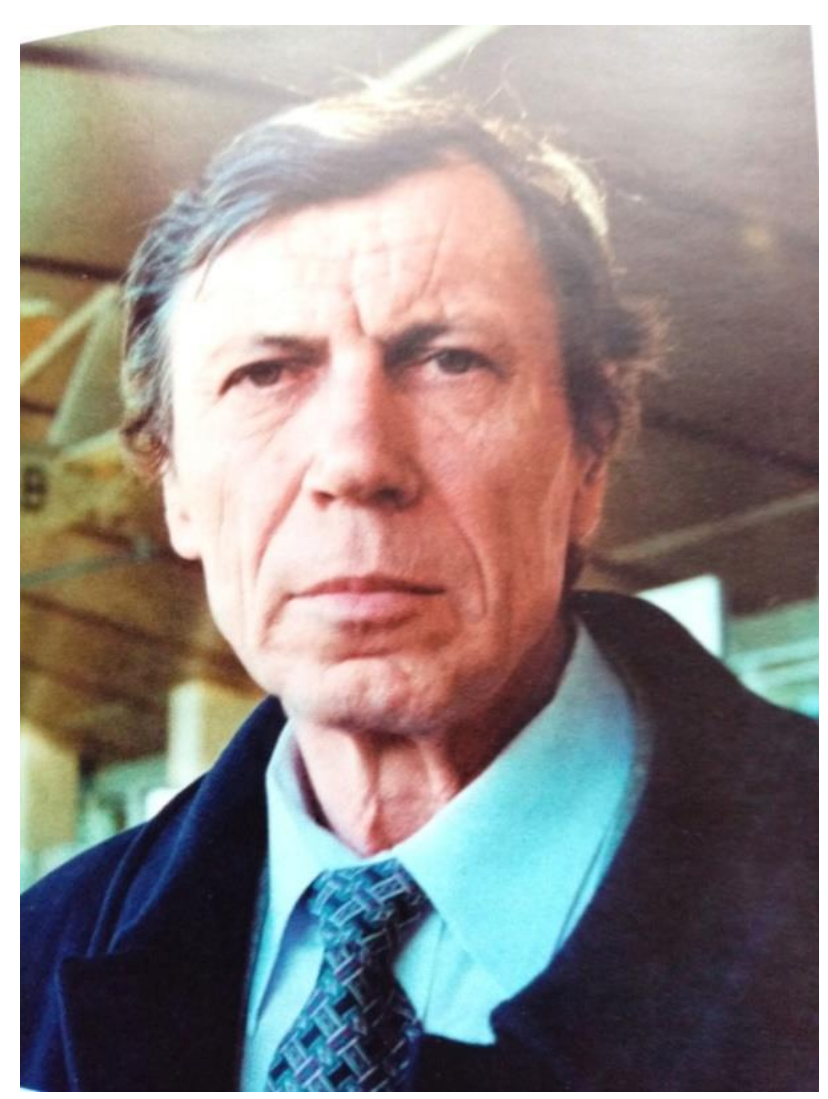

Виктор Иванович Унжаков, главный архитектор города Сургута (1989-2000),

\section{Заслуженный архитектор ХМАО-Югры, Заслуженный архитектор РФ}

Скептическое отношение к перспективе строительства города было вызвано и тем, что строительство домов в Сургуте велось в сложных гидрогеологических условиях. Обследование территорий поселения здесь показало, что при локально заболоченных участках на строительных площадках с линзами торфа мощностью до 1,5-2,0 м предпочтение следует отдавать методу замены торфа грунтом. Исключение могли представлять территории, выделяемые для временного строительства, и площадки, на которых генеральным планом не предусматривалось строительство зданий, сооружений, коммуникаций и других элементов гражданского и промышленного строительства. Если на застраиваемых территориях существовали локально заболоченные участки с линзами торфа мощностью до 1,5-2,0 м. и отдельно заторфованными котлованами и впадинами глубиной до 4-6 м., следовало предусматривать замену торфа грунтом на участке, где мощность торфа не превышала 1.5-2,0 м, и пригруз с частичным выторфованием или без него на 
участках с превышением мощности торфа в 1,5-2,0 м. Для инженерного освоения территорий со значительным или сплошным распространением заболоченных участков с мощностью торфа до 3,0-4,0 м рекомендовалось применять метод коридоров, включающий создание коридоров для трассировки магистральных инженерных коммуникаций, улиц и дренажей с заменой в них торфа на грунт и пригрузку торфа грунтом на площадках между коридорами коммуникаций.

Предлагаемые рекомендации сургутских инженеров-строителей легли в основу конкретных инженерных решений, разработанных институтом «Гипротюменнефтегаз» для проектирования подготовки к строительству территории промышленных баз и поселка нефтяников в Сургуте, где за основу был взят второй вариант. Для освоения значительных по площади и по мощности залегаемого торфа территорий в Сургуте использовался третий метод (88).

Естественно, что эти рекомендации не исключали для проектировщиков необходимость выполнения технико-экономических расчетов, являющихся основой выбора метода для каждого конкретного проекта. Так, например, Заслуженный архитектор России В.И. Унжаков вспоминал, что высокий уровень грунтовых вод и торфяные почвы существенно затрудняли монтаж инженерных коммуникаций на территории нынешнего пятого микрорайона Сургута, где было до пяти-семи метров торфа. Для того, чтобы гам построить жилое здание, торф в зимний период необходимо было выбрать и заменить песком (89).

Тем не менее, как отмечал Виктор Иванович Унжаков, территория застройки Сургута не являлась самой неблагоприятной. В Тольятти и Волгодонске, например, грунты носили просадочный характер, а в Салехарде существовала вечная мерзлота. В Сургуте болота были не трясинные, а верховые. Под всей территории города на глубине 2-3 метров проходила прослойка суглинков. Они не пропускали воду, и во время дождей она естественным образом стекала в Обь. Во время строительства торф выбирался, заменялся песком, вода отводилась и стекала в ливневую канализацию, подпитки для болот не оставалось, поэтому они бесследно исчезали (90).

Проект инженерной подготовки территории промышленных баз и поселка нефтяников в Сургуте вошел в учебные пособия по основам градостроения на севере и стал примером решения этих вопросов в других городах, расположенных на заболоченных и заторфованных территориях с 


\section{ГОРОДСКОЕ СТРОИТЕЛЬСТВО В ХАНТЫ-МАНСИЙСКОМ АВТОНОМНОМ ОКРУГЕ - ЮГРЕ (к.1950-х - сер.1990-х г2.)}

плоским рельефом и высоким уровнем грунтовых вод (91). Этот проект основывался на важнейших закономерностях движения вод в болотных массивах, установленных доктором географических наук, профессором Ленинградского государственного ордена Трудового КрасногоЗнамени гидрологического института К.Е. Ивановым. Тщательное изучение местности в натуре и по материалам наземной и аэрофотосъемки на основе методики К.Е. Иванова позволило установить линию стока на исследуемой территории. Она оказалась направленной от водораздела между реками Обью и Черной перпендикулярно к границе застраиваемого участка с этими реками. Это обстоятельство и предопределило направление трассы основного головного дренажа (92).

Для проектировщиков весьма ценным оказался и ряд других техникоэкономических показателей проекта планировки промышленной зоны и поселка нефтяников в Сургуте. По конкретным проектным данным этого микрорайона была определена также стоимость обустройства одного человека в условиях Среднеобского нефтедобывающего района, то есть обеспечение его жильем, культурно-бытовыми и коммунальными зданиями, детскими, школьными и медицинскими учреждениями. Согласно этим расчетам, стоимость строительства жилья и первоочередного минимума, необходимых общественных и культурно-бытовых предприятий для одного человека составляла в Сургуте 4315 рублей. То же в пересчете на одного работающего при коэффициенте семейственности, равном 3, достигло 12945 рублей. При этом $6,1 \%$ общих затрат на обустройство одного человека в рассматриваемом районе шло на инженерную подготовку территории (93).

Наряду со строительством пятиэтажных домов упрощенной планировки в этом микрорайоне Строительное управление № 9 приступило к заливке фундамента под дома улучшенной планировки, разработанные специально для северян (94). Чуть запоздавшие железнодорожники к 1978 году заселили на станции Сургут три первых жилых дома, построили столовую при локомотивном депо, открыли свой Дом культуры и профсоюзную библиотеку (95).

Высокие темпы панельного строительства актуализировали на севере вопрос теплоизоляции домостроительных конструкций, приобретавший в суровых климатических условиях буквально «жизненное значение». С пуском 27 января 1971 года первой очереди собственного домостроительного комбината в Сургуте стали строиться дома 164-й серии - «ленпроект», разработанный специалистами института ЛенЗНИИЭП и адаптированный к 
климату севера. Ежегодный объем этой серии был самым большим и составлял, например, в 1985 году 195,8 тыс. куб.м. В 1970-е гг. ими для энергетиков была создана 112-я серия, которую выпускал завод железобетонных изделий ежегодным объемом 34,8 тыс. куб.м. Ленпроектовские дома были специально разработаны для Сургута, впоследствии их строили в Надыме, Уренгое, Когалыме, Ноябрьске, Нефтеюганске (96).

Сургутский домостроительный комбинат выпускал также детали домов серии 467А ежегодным объемом 106,7 тыс. м ${ }^{3}$ и 125-ю серию улучшенных «малосемеек», или «трехлистников», особенно актуальных тогда для приезжающей молодежи в условиях дефицита жилья. Опыт жилищного строительства в Сургуте свидетельствует о правильном подходе к расчету жилья на пионерном этапе освоения нефтегазовой территории и определению его номенклатуры с учетом возрастной структуры населения всех строящихся городов. Сургутский домостроительный комбинат с момента своего возникновения стал одним из наиболее активных участников градостроительного процесса в Ханты-Мансийском автономном округе. В 1973 году в Сургуте им построено 14 из 33 пятиэтажных домов. На проектную мощность домостроительный комбинат вышел в 1974 году, после чего в городе выросло 35 пятиэтажек, что свидетельствует об интенсификации городской застройки в округе в эти годы (97).

В середине 1970-х гг. была произведена реорганизация домостроительного комбината: созданы два генподрядных строительномонтажных управления по строительству и сдаче жилья в эксплуатацию для улучшения материально-технического снабжения и комплектации строящихся объектов, Контора материально-технического снабжения была преобразована в Управление производственно-технической комплектации, для уменьшения доли ручного труда и увеличения производительности труда при производстве строительно-монтажных и отделочных работ создан хозрасчетный участок малой механизации.

Тогда же развитие строительной индустрии в Сургуте получило новый импульс. Для строительства новых и реконструкции старых цехов завода железобетонных изделий и строительных материалов было создано генподрядное строительное управление. Это позволило ежегодно обеспечивать прирост выпуска деталей и ввода жилья до 30 тыс. кв. метров в год. В 1977 году завод железобетонных изделий приступил к реконструкции цехов по выпуску деталей домостроения, осуществив эту задачу без снижения объемов 
производства. Если за восемь месяцев 1976 года заводом было выпущено 123 тыс. м $^{2}$, то за соответствующий период 1978 года выпуск составил 139 тыс. м², на 16 тыс. м² больше при одновременном освоении производства новой серии деталей домов (98).

Таким образом, несмотря на то, что к середине 1970-х гг. на севере Тюменской области активно осуществлялся процессе технического перевооружения предприятий производства строительных материалов и конструкций, вводились в строй новые домокомбинаты, дефицит жилья оставался исключительно острой социальной проблемой.

Ее главной причиной являлась недостаточная мощность строительных организаций. Аргументированно вскрывая эту проблему, директор филиала ЛенЗНИИЭПа С.В. Билецкий на пленуме Сургутского горкома КПСС в сентябре 1978 года разъяснял партийному активу: «Сургутский домостроительный комбинат по городу вышел на объем 100-150 тыс. общей площади в год, другими словами, осваивает средства порядка 30-45 млн. руб. в год, что явно недостаточно для комплексного строительства». По его мнению, «мощности строителей города должны ежегодно возрастать на $30-40 \%$, в то время как фактически рост составлял 10-15\%». Он справедливо утверждал, что в результате этого «при согласовании годовых планов треть объемов не утверждается со ссылкой на отсутствие сил, что приводит к срыву выполнения задач экономического и социального развития» (99).

Недостаточная мощность строительных организаций сопровождалась их слабой энерговооруженностью. Техническое оснащение строителей в Сургуте, как и в других районах Тюменского Севера, составляло 10\%, в то время как в центральных регионах РСФСР - 28-30\%. Производительность труда в Сургуте была ниже, чем, например, даже в далеко не южном городе Новосибирске (100).

Объективные природно-климатические и географические факторы строительства на севере Западной Сибири делали проблему создания индустриальной технологической базы на территории нового освоения особенно актуальной. Только индустриализация строительства открывала в сибирских условиях перспективу прорыва в этой отрасли. Радикальным решением всего узла противоречий, которые поставила перед людьми в Сибири природа, мог стать комплексно-блочный метод. Начали его освоение А.С. Барсуков, Ю.П. Баталин, И.А. Шаповалов, В.Г. Жевтун, Г.И. Шмаль, А.Я. Беккер, Я.М. Коган и другие передовые инженеры. Его внедрение дало возможность стране получить на год раньше срока 30 млн. тонн нефти и 
существенно повысить по многим показателям эффективность гражданского строительств (101).

По схеме комплексно-блочного строительства собственно возведение промысловых и некоторых гражданских объектов переносилось со множества разбросанных площадок в заводские условия. Предполагалось, что в обстановке заводского производства на потоке будут изготавливаться многие изделия и заготовки. Здесь же будут создаваться блоки промысловых и гражданских объектов, которые должны транспортироваться на строительные площадки.

Этот метод применялся и в градостроении. В 1976 году для поселка вблизи Сургута была введена котельная весом 350 тонн. Она была смонтирована на барже и доставлена к месту назначения водой. На ее установку и запуск ушло менее месяца, в то время как нормативный срок строительства составлял около года (102).

Инициатива многих других полезных начинаний родилась в ХМАО-Югре. Именно здесь были построены первые установки по выпуску перлита, изоляции труб теплотрасс в битумно-керамзитовой оболочке. Здесь же были внедрены передовые инженерные решения по освоению нулевых циклов зданий и сооружений. Среди новаторов индустриального строительства выделялись тогда молодые специалисты и руководители производства А. Касьянов, Л. Рокецкий, М. Собсович, В. Павлов, А. Холмогоров, М. Чижевский. В Сургуте была создана первая в стране научнопроизводственная фирма «Сибиргазстрой» (103).

На первом этапе промышленного и социального обустройства территории новой нефтегазовой провинции инженеры А.С. Барсукова существенно продвинулись вперед во внедрении прогрессивных технологических методов строительства. Но произошло это в значительной мере благодаря их энтузиазму, реализованному в условиях полукустарного проектирования и почти ремесленного производства в неприспособленных цехах непрофильных производств.

Необходимой поддержки со стороны государственных хозяйственных органов А.С. Барсуков не получил. Руководство страны не смогло найти необходимых средства для обеспечения многих передовых инженерных решений в строительной индустрии. Таких, например, как получение прогрессивных полимерных материалов, новых утеплителей и качественного алюминия. 
После знакомства с американскими суперблоками массой 1300 тонн Ю.П. Баталин, оценивая разработанный в годы работы А.С. Барсукова метод, отмечал, что просчет во внимании государственного руководства к индустриализации строительства главного топливного региона страны дорого обошёлся обществу и самой Западной Сибири. По его мнению, «обустройство могло и должно было быть, как задумывал А.С. Барсуков, более экономически корректным, менее ресурсозатратным, а самое главное - менее трудоемким, что позволило бы избежать привлечения в Сибирь десятков тысяч человек» (104).

\section{Примечания}

1. Государственный архив Тюменской области (ГАТО). Ф.1861. Оп.1. Д.1. Л.12.

2. Государственный архив социально-политической истории Тюменской области (ГАСПИТО). Ф.107.Оп.1.Д.224.Л.36-37.

3. Захаров И.П. Так было... // Новый город.2002. 21 августа.

4. Там же.

5. Марченков В.И.. Марченкова Г.И. Так это было. Сургут, 2001. С.73.

6. Дворникова Т. Здесь будет город сад? // Новый город.200. 28 февраля.

7. Долгая дорога к нефти. Сургут, 1997. С.71.

8. Розанов И.П. Крупнопанельное домостроение. М., 1982. С.100.

9. Там же.

10. Там же.

11. Там же.

12. Режим доступа: pikabu.ru/story/gorodsovetskiychast5surgutIsovetskiy urbanizmnasevere7709588

13. Розанов И.П. Указ.соч. С. 100

14. Сургутские ведомости. 2003. 10 ноября.

15. ГАСПИТО. Ф.124. Оп.200.Д.44. Л.5.

16. ГАСПИТО. Ф.1861. Оп.1.Д.6.Л.5.

17. ГАСПИТО.Ф.2010.Оп.1.Д.170.Л.5.

18. ГАТО. Ф.1861. Оп.1. Д.1. Л.18.

19. ГАТО. Ф.1861. Оп.1. Д129. Л.44.

20. ГАТО. Ф.1861. Оп.1. Д.1. Л.19.

21. ГАСПИТО. Ф.124. Оп.191.Д.73.Л.34.

22. Там же.

23. ГАСПИТО. Ф.124.Оп.1. Д.4065. Л.105. 
24. Там же. Л.106.

25. Там же.

26. ГАСПИТО. Ф.124. Оп.91.Д.73.Л.74.

27. Там же.

28. Там же. Л.108; ГАСПИТО. Ф.124.Оп.1.Д.4506.Л.4

29. Там же. Л.114.

30. Мамлеев Ш.М. Указ. Соч. С.11.

31. Долгая дорога к нефти. Сургут, 1997.С.163.

32. Судаков В.В. Тюменская быль. М., 1989.С.25.

33. ГАСПИТО. Ф.113.Оп.1.Д.30.Л.106.

34. Там же. Л.128.

35. Там же.

36. Баталин Ю.П. Воспоминания и взгляды. История и перспективы градостроительного освоения территории севера. Западно-Сибирский нефтегазовый комплекс. М., 2004.С.32

37. 38.Материалы ХХ111 съезда КПСС. М., 1966. С.132

38. Там же.

39. Баталин Ю.П. Воспоминания и взгляды. История и перспективы градостроительного освоения территории севера. Западно-Сибирский нефтегазовый комплекс. М., 2004.С.32.

40. ГАСПИТО.Ф.124.Оп.84.Д.64.Л.35; ГАТО. Ф.1861 Оп.1. Предисловие. Л.1.

41. Рычков Б.Соратники. Тюмень, 2002.С.75

42. Чинчевич А. Все остается людям // Соратники. Тюмень, 2002.С.76

43. Рычков Б. Сибирь-Иран // Соратники. Тюмень, 2002.С.75

44. ГАСПИТО.Ф.124. Оп.84. Д.64.Л.35; ГАТО. Ф.1861. Оп.1. Предисловие. Л.1.

45. ГАТО.Ф. 1861. Оп.1. Предисловие. Л.1-3.

46. Баталин Ю.П. От игр в кубики к «суперблокам» // Соратники. Тюмень, 2002. С.79

47. ГАСПИТО.Ф.П-124.Оп.1.Д.4506.Л.4

48. ГАСПИТО. Ф.П-124.Оп.1.Д.4506.Л.4(об)

49. Там же. Л4 (об)-5

50. Там же. Л.5.

51. Там же.

52. Там же. 
53. ГАТО. Ф.1861. Оп.1. Предисловие. Л.4.

54. ГАТО. Ф.1861. ОП.1. Д.1. Л.20.

55. Архивный отдел администрации города Нижневртовска.Ф.100.56 ед.хр. (1979-1991 гг.).

56. Архивный отдел администрации города Нижневартоска.Ф.27/131-л, 705 ед.хр. (1979-2000 гг.)

57. ГАСПИТО.Ф.124.ОП.191.Д.27.Л.3

58. ГАСПИТО.Ф.124. Оп.191.Д.27.Л.17

59. Режим доступа: www.trsm 72.ru. Тюменский комбинат строительных материалов.

60. Там же.

61. Режим доступа: zavodfoto.Likejournal.com. История промышленности России в фотографиях: ООО « Инвест-селикат-стройсервис».

62. Там же.

63. Режим доступа: www.lib.kingi-x.ru. ЗАО «Завод ЖБИ-3»: Продолжение биографии.

64. Режим доступа: www.tyumen-city.ruviasat...administrativekatalogyfondov.

65. ГАСПИТО.Ф.1.Оп.191.Д.27.Л.356.

66. Режим доступа: www.trsm 72.ru Тюменский комбинат строительных материалов

67. Донгорян Ш.С. Указ. соч. С.190.

68. Режим доступа: ru.wikipedia.org /wiki/ Городские населенные пункты Ханты - Мансийского автономного округа; Филипенко А.В. Указ.соч. С.138.

69. Донгорян Ш.С. Указ. соч. С.190.

70. Население Тюменской области. Режим доступа: https://yandex.ru/ images/search? text 1091/ Заглавие с экрана

71. Там же.

72. ГАТО. Ф.1861 Оп.1. Д.1. Л.20

73. Донгорян Ш.С. Указ.соч.С.190

74. Там же.

75. Там же. С.190-191

76. Там же. С.191.

77. Там же. С.189.

78. ГАСПИТО. Ф.124. Оп.191. Д.73. Л.67

79. Донгорян.Ш.С.Указ. соч. С.190. 
80. Ярошко А. Первый государственный. // Югра.1997.Июль. № 7. С.17.

81. Там же.

82. Там же.

83. Годы и люди Сургутской ГРЭС. С 23.

84. АОАГС.Ф.80. Оп.2. Д.82. Л.23.

85. АОАГС. Ф.3. Оп.1.Л.47.Л.168.

86. См.: Сургутские ведомости. 2003. 10 ноября.

87. Там же.

88. История и перспективы градостроительного освоения...С.92.

89. Унжаков В.И. Пока город строится, он живет. // Новый город. 2003. 9 августа.

90. Там же.

91. История и перспективы градостроительного освоения... С.101.

92. Там же.

93. Там же. С.103.

94. Долгая дорога...С.78.

95. Патранова В., Цареградская Л. Линия нашей жизши. Сургут, 2003. C.61, 189.

96. ГАТО. Ф.1861. Оп.1. Д.11. Л.16

97. Город Сургут в цифрах (Юбилейный статистический сборник). Сургут, 1995. С.36.

98. ГАСПИТО. Ф.103. Оп.31.Д.7. Л.103.

99. ГАСПИТО.Ф.113. Оп.31.Д.1.Л.1

100. ГАСПИТО.Ф.124.Оп.19. Д.4.Л.53

101. Вергасов. Ф. Сибирский «дед» с Орденом Двуречья. Режим доступа: htpp://www. psihologi.org/batalin/barsucov httm.- Загл. с экрана.

102. Баталин Ю.П. От игр в кубики к «суперблокам»// Соратники. Тюмень, 2002. С.81.

103. Вергасов. Ф. Сибирский «дед» с Орденом Двуречья. Режим доступа: htpp://www. psihologi.org/batalin/barsucov httm. - Загл. с экрана.

104. Баталин Ю.П. Указ.соч. С.81. 


\section{ГЛАВА 5. \\ ЖИЛИЩНОЕ СТРОИТЕЛЬСТВО В НОВЫХ СЕВЕРНЫХ ГОРОДАХ}

Начавшееся в 1960-е гг. интенсивное промышленное освоение края при отсутствии комплексной программы социально-экономического развития и генерального планирования городов и поселков предопределило ведомственный характер их застройки «методом хуторского хозяйства», как иронизировали тогда проектировщики. Ситуация усугублялась тем, что Совет Министров СССР в своем Постановлении от 4 декабря 1963 года № 1208 разрешил Совету Министров РСФСР и Государственному Комитету по газовой промышленности СССР в виде исключения осуществлять до 1 января 1965 года жилищное и промышленное строительство, связанное с обустройством нефтяных и газовых промыслов и разведок в Тюменской области, а также строительство производственной базы и жилых домов для соответствующих строительных организаций по рабочим чертежам и сметам на отдельные объекты (1). Эта «временная мера» стала «постоянной» для всего протяжения 1960-х гг. Местническая организация строительства лежала в основе градостроительной политики на территории округа и преодолевалась весьма болезненно.

Например, несмотря на то, что еще в 1971 году был определен генеральный заказчик по проектированию и строительству Сургута Миннефтепром (ПО «Сургутнефтегаз»), вопрос о едином заказчике не был решен до конца исследуемого периода. Наиболее активно за объединение заказчиков под эгидой «Сургутнефтегаза» боролся заместитель генерального директора этого объединения, возглавивший в 1977 году его Управление капитального строительства Г.М. Кукуевицкий. 


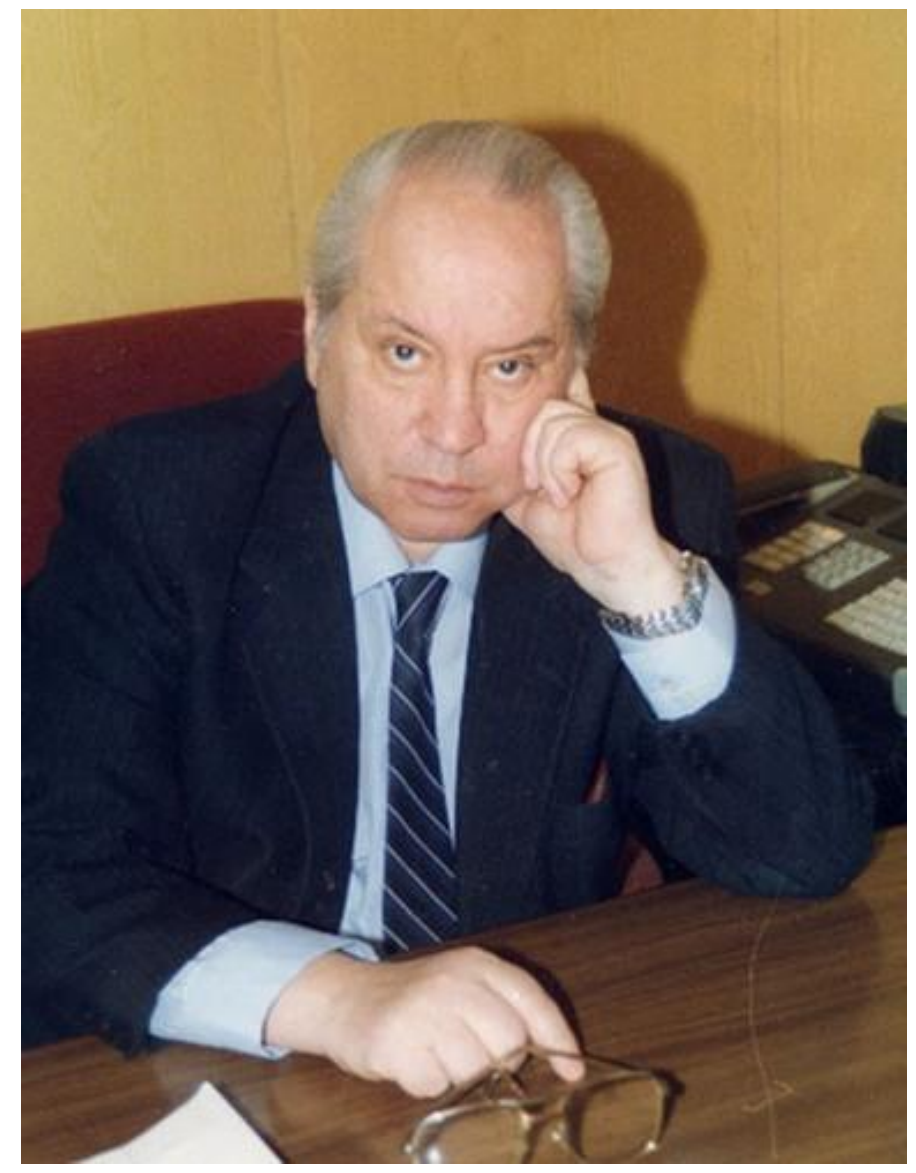

Григорий Михайлович Кукуевицкий, заместитель начальника по строительству п/о «Сургутнефтегаза» (1966-1970), заместитель генерального директора по строительству п/о «Сургутнефтегаза» (1977-1994)

После окончания Азербайджанского института нефти и химии Г.М. Кукуевицкий трудился на нефтепромыслах Татарии, а в начале 1966 года приехал в Сургут, которому посвятил 28 лет жизни. Опираясь на Постановление Совета Министров СССР № 919 от 21 декабря 1971 года и совместное Постановление ЦККПСС и Совета Министров СССР № 123 от 9 февраля 1978 года, определявшие в качестве генерального заказчика по проектированию и строительству города «Сургутнефтегаз», он неоднократно официально обращался ко всем организациям города с предложением принять от них в установленном порядке объекты капитальных вложений с планом подрядов, лимитов по труду и фондов на материалы и оборудование. Аналогичными были предложения и по проектно-изыскательским работам (2). 
C такими же предложениями «Главтюменнефтегаз» обращался к руководителям всех главков организаций, дислоцированных в Сургуте. Однако те и другие оставляли эти предложения без внимания, хотя на всех городских заседаниях и активах они ратовали о едином заказчике, отсутствие которого, по их формальному утверждению, препятствовало выполнению установленной государственной программы городского строительства в Сургуте. Странное консолидированное ведомственное молчание по поводу предложений Г.М. Кукуевицкого выглядело особенно нетерпимым, если учесть, что государственная программа по строительству жилья в Сургуте, очерченная в названных постановлениях ЦК КПСС и Совета Министров СССР, предусматривала для нефтяников и миннефтегазстроевцев почти равные объемы городского строительства (3).

Следует, однако, признать, что «отличный строитель-нефтяник, грамотный руководитель», по оценке генерального директора «Сургутнефтегаза» Н.П. Захарченко, Г.М. Кукуевицкий и специалисты УКСа нефтегазового объединения, а также Строительно-монтажный трест № 1 под руководством А.Ф. Мухи внесли большой вклад в преодоление ведомственнохуторской застройки, формирование современной инфраструктуры города, заполняя «бреши» между старыми поселками и новыми микрорайонами. Сокращалось и число заказчиков. Если в 1978 году их насчитывалось около 30(4), то в 1981 году в качестве заказчиков выступало пять основных министерств: Миннефтепром, Мингазпром, Минэнерго, Мингео, Миннефтегазстрой (5). Вся территория города, примерно 30 микрорайонов, была закреплена за отдельными заказчиками. За Миннефтепромом - 13 поселений, за Минэнерго - 5 и т.д. (6). Они представлены в таблице № 8 (7).

\section{Таблица № 8}

Основные заказчики строительства в Сургуте (кв.м.)

\begin{tabular}{|l|c|c|}
\hline \multicolumn{1}{|c|}{ Заказчик } & $\begin{array}{c}\text { План } \\
\text { года, } \mathbf{m}^{2}\end{array}$ & $\begin{array}{c}\text { Факт } \\
\text { года, } \mathbf{m}^{2}\end{array}$ \\
\hline п/о «Сургутнефтегаз» Миннефтепрома & 66116 & 71372 \\
\hline п/о «Сургуттрансгаз» Мингазпрома & 23572 & 29424 \\
\hline РЭУ «Тюменьэнерго» Минэнерго & 49100 & 34333 \\
\hline п/о «Обьнефтегеология» Мингео & 17195 & 17149 \\
\hline Дирекция строящихся промпредприятий Миннефтегазстроя & 31853 & 35467 \\
\hline Прочие & 48766 & 56879 \\
\hline
\end{tabular}


Из таблицы следует, что, несмотря на заметную концентрацию заказов пятью министерствами, ведомственную разобщенность преодолеть не удалось. Весьма показательным являлось то, что на долю «прочих» организаций приходилось 56879 кв. м. строительства, что почти в два раза превышало, за исключением «Сургутнефтегаза», строительные объемы других заказчиков.

Поэтому формирование своеобразного и выразительного архитектурнохудожественного облика городов ХМАО-Югры являлось процессом сложным и во многом противоречивым, зависящим от коллективной организационноплановой работы. В 1978 году на пленуме Сургутского городского комитета партии неслучайно звучала критика в адрес строителей «Сургутгазстроя»: «Нельзя не сказать о том, что ведущий городской трест, каковым является «Сургутгазстрой», по непонятным ни для кого указаниям «Главтюменнефтегазстроя», ориентирован на строительство явно не городских объектов, каковыми являются нефтеперекачивающие станции, заводы для нужд нефтяной промышленности». Ведомственная разобщенность, проявлявшаяся в различных сферах жизнедеятельности Сургута, оказывала отрицательное воздействие на возможность проведения единой централизованной градостроительной политики (9).

На протяжении исследуемого периода в городе не был решен вопрос и о создании службы единого генподрядчика. Осознание этого партийными и хозяйственными руководителями строительного комплекса позволило к 1985 году в Сургуте сконцентрировать строительство в руках трех основных подрядных организаций: ДСК «Главсибжилстроя», ДСК Минэнерго, треста «Сургутгазстрой». Их вклад в жилищное строительство представлен в таблице № 9 (9).

\section{Таблица № 9}

Вклад основных подрядных организаций в жилищное строительство Сургута в 1985 году

\begin{tabular}{|c|c|c|}
\hline Заказчик & План года, $\mathrm{M}^{2}$ & Факт года, $\mathrm{m}^{2}$ \\
\hline ДСК «Главсибжилстроя» & 141477 & 158626 \\
\hline ДСК Минэнерго & 61530 & 35518 \\
\hline Трест «Сургутгазстрой» & 5812 & 5812 \\
\hline
\end{tabular}




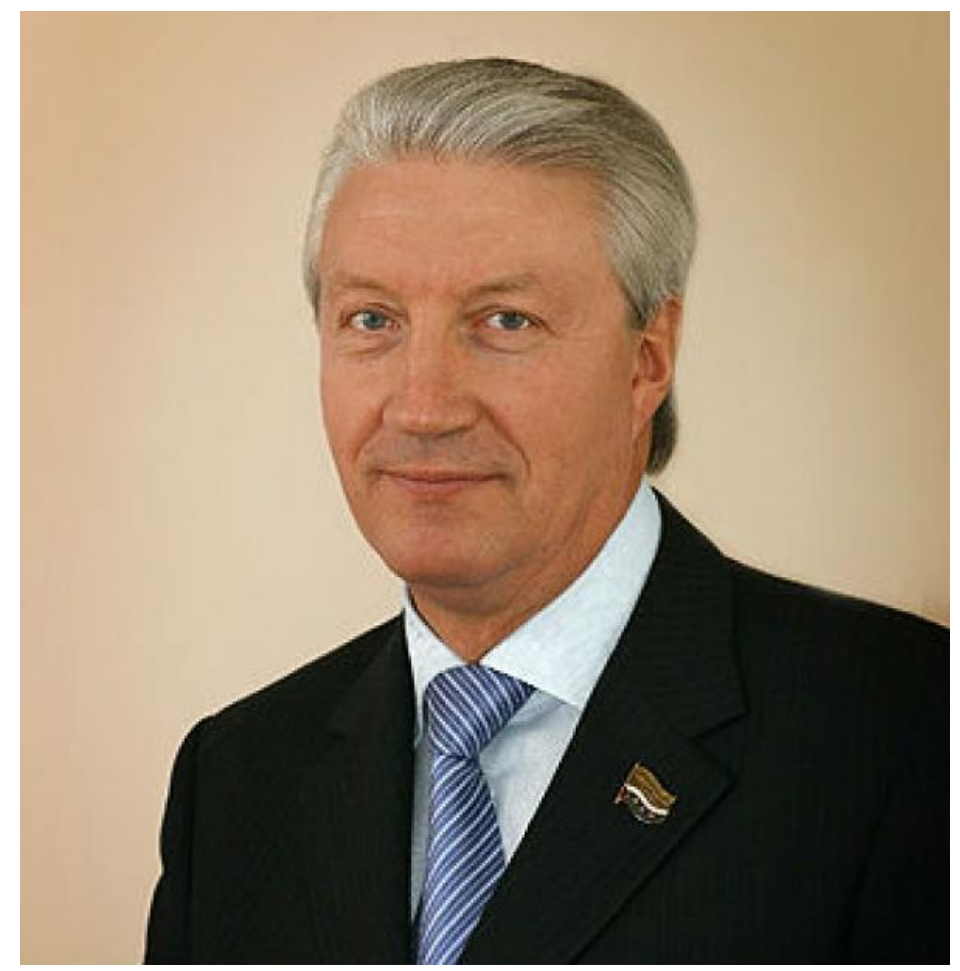

Александр Леонидович Сидоров,

главный инженер, начальник СУ-9 треста «Сургутгазстрой» (1978-1987), главный инженер треста «Сургутгазстрой» (1987-1988), заместитель Председателя (1989-1990), председатель горисполкома, глава администрации, мэр города Сургута (1990-2010)

Как следует из таблицы, в качестве главной подрядной строительной организации в исследуемый период выступал Сургутский домостроительный комбинат, чьи объемы вводимого жилья в 5 раз превышали показатели ДСК Минэнерго и были значительно больше, чем у «Сургутгазстроя». Однако трест «Сургутгазстрой» вносил наибольший вклад в строительство объектов социального, культурного и бытового назначения.

Такой концентрации и специализации подрядных работ было недостаточно. Заместитель генерального директора объединения «Сургутнефтегаз» Г.М. Кукуевицкий справедливо отмечал: «Вторым немаловажным фактором, влияющим на комплексную застройку города, является отсутствие единой генподрядной организации. На сегодняшний день Сургутский домостроительный комбинат, тресты «Сургутгазстрой» и «Спецгазстрой» выступают в роли генподрядчиков, при этом зачастую пикирующих друг с другом, а не решающих главную задачу» (10). 
Положение осложнялось тем, что в городе не было единого подрядчика по строительству улиц, дорог и магистральных сетей. До середины 1990-х гг. в Сургуте отсутствовали специализированные подразделения по благоустройству и озеленению города.

Как мы отмечали, с 1971 года функции генерального проектировщика стал выполнять Сургутский филиал ЛенЗНИИЭПа. Однако проектную документацию для селитебной зоны готовили и другие проектные организации. А основным проектировщиком промзоны являлся Московский проектный институт № 2 и позднее «Промстройпроект» в г. Тюмени.

Дисперсный характер стартовой застройки Сургута усугублялся отсутствием в городе органов архстройконтроля. В соответствии с положением о государственном архстройконтроле РСФСР разрешения на производство работ должны были выдаваться областной инспекцией госархстройконтроля. Однако в Сургуте, как правило, строительство велось либо без разрешения на производство работ, либо разрешение выдавалось самими заказчиками, что являлось прямым нарушением порядка, установленного законодательством. Главный архитектор города А.А. Асеева откровенно писала 4 ноября 1969 года в служебной записке начальнику областного отдела по делам строительства В.Д. Бешкильцеву и начальнику областной инспекции архстройконтроля Л.А. Новопрудецкой: «... я не в курсе дела, какие объекты и где строятся, соответствуют ли они генплану, обеспечены или нет финансированием и необходимой проектно-сметной документацией, каковы сроки начала и окончания строительства» (11).

В Нижневартовске состояние архитектурного контроля начало меняться к лучшему только в начале 1990-х гг., когда в 1991 году была создана Инспекция государственного архитектурно-строительного контроля управления архитектуры и градостроительства исполкома Нижневартовского городского Совета народных депутатов, преобразованная в 1992 году в государственный архитектурно-строительный надзор администрации города Нижневартовска. В 2002 году статус этого регламентирующего органа существенно возрос вследствие того, что был создан Нижневартовский городской отдел инспектирования Инспекции государственного архитектурно - строительного надзора департамента градостроительной политики, ставший в том же году непосредственной структурой Департамента строительства ХантыМансийского автономного округа (12). 
Создаваемые органы государственного архитектурно-строительного надзора за соблюдением хозяйствующими субъектами обязательных требований государственных норм и стандартов, технических условий, строительных норм и правил, проектов, других нормативных актов в области строительства и промышленности строительных материалов по мере совершенствования своей работы и усиления своего правового влияния сыграли решающую в торможении инерции утверждения ведомственного фактора в сфере реализации строительства и функционирования новых городов ХМАО-Югры, когда в начале своего нового рождения Сургут, например, представлял собой конгломерат разбросанных по обширной территории, слабо взаимосвязанных между собой, практически автономных ведомственных микрорайонов: геологов - на востоке, нефтяников - на западе, строителей - в центре, энергетиков - на севере. На приличном расстоянии за лесом чуть позже распростерся «хутор железнодорожников».

Каждое ведомство на вверенной ему территории не только имело «свой» жилой фонд, но и «свои» предприятия связи, торговли, общественного питания, бытового обслуживания, учреждения культуры и отвечало за их эксплуатацию. Эксплуатацией жилого фонда города занимались 20 организаций, водозаборными сооружениями - 13, связи - 16 предприятий различных ведомств и министерств, торговлей и общественным питанием - представители 5 ОРСов 8-ми министерств (12). Освоение городской территории отдельными ведомствами затрудняло комплексную застройку Сургута. Размещение селитебных территорий на сильно расчлененных участках вызывало удорожание строительства на 15-20\% (13).

Система ведомственного формирования городов округа приводила к хроническому однообразию повторения этапов его развития: дефицит всякого рода жилья переходил в дефицит детских садов и яслей, затем школ, объектов социально-бытового обслуживания. Последние чаще всего были сведены к примитивной форме клуба не как центра культуры, а как коммерческого прокатного заведения с узкой программой. Такая деформация социальной среды возникала в силу давно установленных причин: при ведомственном распределении средств на гражданское строительство городов определялся минимальный набор объектов их жизнеобеспечения, а при многоведомственном освоении картина еще более усугублялась. У рождающихся городов Югры не было единых хозяев. Местные Советы кредитами не распоряжались. 
Опыт создания новых городов на севере Западной Сибири показывает, что прогрессивные планы городского строительства успешно реализуются только при тесном содружестве единого генерального заказчика, генерального подрядчика и генерального проектировщика. При общей критической оценке отсутствия «единого хозяина» на начальном этапе городского строительства в «нефтяных городах» и формирования их селитебной зоны по профессиональному признаку - поселки геологов, строителей, нефтяников, энергетиков, железнодорожников - следует отметить, что такое районирование являлось результатом не только ведомственного финансирования, но и отражением самого процесса формирования городов по этапам освоения нефтегазовой территории: разведка, обустройство, нефтедобыча, транспорт.

Рискнем высказать и ряд положительных замечаний по этому поводу. В первые годы строительства городов важно было предусмотреть освоение в первую очередь участков, наиболее пригодных для застройки, резервировать для строительства на более поздних этапах или использовать для других целей территории, требующие значительных затрат на инженерную подготовку. В условиях ландшафта округа это имело особое значение. Пригодные для застройки площадки здесь были разобщены заболоченными и заторфованными участками, оврагами и ручьями. Освоение этих участков в первый, наиболее трудный период строительства города было экономически не оправдано. Невыполнение этого требования приводило к нарушению плана регулирования застройки. В то же время необходимо было резервировать для основных массивов жилой застройки города наиболее здоровые территории. Поэтому дисперсная структура города в виде отдельных компактно застраиваемых планировочных районов имела объективные причины (14).

Это очень хорошо понимал главный архитектор Сургута в период становления Западно-Сибирского нефтегазового комплекса В.И. Унжаков, который писал: «... нас в свое время критиковали, что мы размещали строительство жилья разрозненно, по ведомствам. Всем хотелось воспринять город единым. Но мы не могли допустить размещения на одном пятачке 4-5 строительных ведомств. Нужно было задействовать всю силу каждого ведомства, быстрее получить жильё, благоустройство, инфраструктуру по всему городу, ведь это - север» (15).

Заметим, что значительная часть территории, не вошедшей в площадь первоначальной застройки, позднее была использована как коридоры для прокладки инженерных коммуникаций, теплотрасс, линий электропередач, 
газопроводов, складских и прочих нежилых помещений, защитных зон и зон отдыха. По мере их освоения структура новых городов становилась все более центростремительной и компактной, нейтрализуя идентичность первозданных поселений.

Таким интегрирующим фактором централизованной застройки можно считать деятельность строительного Управления 219 треста «Главревмостсой», который начал свою работу в Нижневартовске в мае 1980-го года во главе с В.П. Кураковым. Трест вводил ежегодно около $60000 \mathrm{M}^{2}$ жилья, в основном это были девятиэтажные дома. Работы велись двумя строительными потоками, ломая границы «ведомственных пятачков» и органически включая их в единое централизованное жилищное пространство города. С 1982 года СУ-219 перешло на строительство современных комфортабельных шестнадцатиэтажных домов. Комплектующие для их строительства: плиты, обои, краски, сантехнику - поставляли московские домостроительные комбинаты. Это придавало архитектурному образу города особый «московсковартовский шарм». После реорганизации в 1986 году СУ-219 в трест «Мосзапсибстрой» ввод жилья увеличился до 100000 кв.М. в год. Его руководителем стал А.В. Добынцев. Трест занимался не только строительством жилищного фонда, но и объектов социального назначения: детских садов, поликлиник, школ. Все объекты сдавались в срок и под ключ. Предприятие закончило свою деятельность после образования в Нижневартовске собственного промышленного строительного комбината (16).

О собственном окружном характере застройки Нижневартовска свидетельствует стремительный темп образования на его территории строительно-монтажных трестов и управлений.

В 1971 году был создан строительно-монтажный трест «Нижневартовскнефтестрой» Главтюменнефтегаза Министерства нефтяной промышленности СССР, который, выполняя строительно-монтажные работы по обустройству нефтегазовых месторождений и промышленных объектов, значительное внимание уделял возведению объектов жилья и соцкультбыта (17).

В том же году было образовано значительно усилившее энергетический потенциал строительного комплекса города Нижневартовское Управление механизации строительно-монтажного треста «Нижневартовскжилстрой». С началом его работы заметно улучшилась обеспеченность строительства механизмами и техническими средствами, улучшился ремонт строительного оборудования и подъездные пути к стройкам (18). 


\section{ГОРОДСКОЕ СТРОИТЕЛЬСТВО В ХАНТЫ-МАНСИЙСКОМ АВТОНОМНОМ ОКРУГЕ - ЮГРЕ (к.1950-х - сер.1990-х г2.)}

Внимание к техническому совершенствованию градостроения в Нижневартовске, механизации выполнения строительных операций прослеживается на всех этапах его застройки. После создания Управления механизации в 1971 году в 1986 году было создано Управление малой механизации. Оно являлось структурным подразделением созданного ранее в 1975 году треста «Нижневартовскспецстрой» Главтюменстроя Министерства промышленного строительства СССР и внесло свой значительный вклад в совершенствование технологических операций выполняемого им жилищного и гражданского строительства в городе Нижневартовске. Ориентированный в своей производственной деятельности на строительство объектов жилого и социально-бытового назначения, он стоял у истоков строительства автодорог, внешних коммуникаций, инженерных сооружений и благоустройства города (19).

Город Нижневартовск с момента основания отличался приятным эстетическим видом, не в последнюю очередь благодаря высокому уровню внутренних и внешних отделочных работ. И это неслучайно, потому что с 1972 года в нем функционировало специализированное Управление отделочных работ специализированного треста «Нижневартовскспецстрой», сумевшего, несмотря на все административные потрясения 1980-1990-х гг., сохранить свой высокий профессиональный авторитет на протяжении длительного времени - до 2001 года, связанного с невыясненными причинами его ликвидации (20).

Вместе с уплотнением застройки неуклонно росла и численность населения городов, которая отражена на примере одного из наиболее показательных из них города Сургута в таблице № 10.

Напомним, что в 1957 году в Сургуте вместе с Черным Мысом проживало всего 5 тыс. человек. Из таблицы видно, что к 1965 году число горожан возросло до 11000 человек, а к 1966 году увеличилось до 15600 жителей, т.е. более чем в 3 раза, по сравнению с 1957 годом. В 1970 году численность населения Сургута составляла 34000 человек, что почти в 7 раз превышало уровень 1957 года.

В Сургуте в начале 1964 года имелось всего 16 тыс. м² жилой площади всех ведомств и 18 тыс. м частного сектора, т.е. в целом - 34,2 тыс. м² жилья, которого в рабочем поселке катастрофически не хватало. В расчете на душу его населения это составляло примерно $3 \mathrm{M}^{2}$ при санитарной норме $9 \mathrm{M}^{2}$ и расчетной 7 м². Исходя из расчетной нормы жилплощади на 1 человека 148 
планируемого населения, в 1965 году необходимо было ввести в строй 120 тыс. м² жилой площади. Это в четыре раза превышало имеющуюся в наличии жилую площадь. Реально же, согласно титульным спискам, до конца года предполагалось построить $12850 \mathrm{~m}^{2}$ жилья при потребности более чем в $73000 \mathrm{M}^{2}(21)$.

Таблица № 10

Численность населения Сургута

\begin{tabular}{|l|c|}
\hline \multicolumn{1}{|c|}{ Годы } & Всего жителей \\
\hline 1965 & 11000 \\
\hline 1966 & 15600 \\
\hline 1970 (по переписи на 15 января) & 34000 \\
\hline 1975 & 58897 \\
\hline 1979 (по переписи на 15 января) & 106724 \\
\hline 1980 & 120800 \\
\hline 1985 & 203300 \\
\hline 1989 (по переписи на 15 января) & 250198 \\
\hline 1990 & 256700 \\
\hline 1991 & 261800 \\
\hline 1992 & 259800 \\
\hline 1993 & 258500 \\
\hline 1994 & 259200 \\
\hline 1995 & 263000 \\
\hline
\end{tabular}

Прибывающим рабочим и специалистам реально грозила опасность остаться зимой 1964-1965 гг. без жилья. Они вынуждены были обратиться к председателю Сургутского райисполкома А.Г. Григорьевой с просьбой разрешить им самостоятельное строительство. Райисполком дал согласие на строительство 50 деревянных балков. Построили 380. Когда стали отставать со строительством котельной из-за отсутствия оборудования, начали внутри смены вести монтаж и наладку старых списанных котлов, чтобы дать тепло и не замерзнуть. Жили по восемь человек в комнате, предназначенной для двоих.

Наиболее комфортным жильем в то время считались комплектнобрусчатые восьмиквартирные, двенадцатиквартирные и шестнадцатиквартирные дома, производство которых осуществлялось на Белгородском лесопильном заводе стандартных сборных брусовых домов. В 1964 году для создаваемых в Тюменской области поселков и городов, предприятий и 
организаций объединения «Тюменнефтегаз» Тюменского территориального геологического управления и Государственного производственного комитета по газовой промышленности СССР трудовой коллектив завода взял на себя обязательство изготовить 10 тыс. м² таких домов, а в 1965 году - 24 тыс. м² (18). В Сургуте их сборку осуществляло Строительное управление № 9, которое вместе с СУ-10 одним из первых было сформировано в 1964 году. По состоянию на 24 сентября 1964 года в СУ-9 поступило 84 четырехквартирных дома, 9 восьмиквартирных домов, 6 общежитий ОЩ-60. Из них под крышей находилось 17 брусовых восьмиквартирных домов и 3 общежития ОЩ-60. Для срочного окончания работ по брусовым домам и общежитиям СУ-9 недоставало $21420 \mathrm{~m}^{2}$ сухой штукатурки и дерево-плиты для обшивки потолков и перегородок, 785 м $^{3}$ минваты для утепления, 32 т газовых труб для утепления, 10 т масляных красок (22). Несмотря на хронические задержки поступления строительных материалов, коллектив рабочих и специалистов СУ-9 успешно справился с поставленными задачами. Итоги выполнения плана строительно-монтажных работ представлены в таблице № 11 (23).

Таблица № 11

\section{Технико-экономические показатели выполнения плана} строительно-монтажных работ по Строительному управлению № 9 треста «Татнефтепроводстрой» за 1964 год

\begin{tabular}{|c|c|c|c|}
\hline \multirow{2}{*}{ Наименование заказчика } & \multicolumn{3}{|c|}{ Выполнение } \\
\hline & план, м $^{2}$ & факт, $\mathrm{M}^{2}$ & $\%$ \\
\hline \multicolumn{4}{|c|}{ «Главгеология» } \\
\hline Жилищное строительство & 700000 & 1007928 & 143,9 \\
\hline Культурно-бытовое строительство & 786000 & 53712 & 6,8 \\
\hline Промышленное строительство & 570000 & 59735 & 10,5 \\
\hline Ввод жилья, м² & 4575 & 3852,6 & 84,2 \\
\hline ИТОГО & 2056000 & 1121372 & 54,5 \\
\hline \multicolumn{4}{|c|}{ НПУ «Сургутнефть» } \\
\hline Жилищное строительство & 150000 & 225600 & 150,4 \\
\hline Культурно-бытовое строительство & 14563 & & \\
\hline Промышленное строительство & 23741 & & \\
\hline Ввод жилья & 660 & 690 & 104,5 \\
\hline ИТОГО & 150000 & 263904 & 175,2 \\
\hline \multicolumn{4}{|c|}{ Газпром СССР } \\
\hline Жилищное строительство & 395000 & 1389756 & 351,8 \\
\hline Культурно-бытовое строительство & & & \\
\hline
\end{tabular}


ГОРОДСКОЕ СТРОИТЕЛЬСТВО В ХАНТЫ-МАНСИЙСКОМ

АВТОНОМНОМ ОКРУГЕ - ЮГРЕ (к.1950-х - сер.1990-х г2.)

\begin{tabular}{|l|c|c|c|}
\hline Промышленное строительство & 251000 & 168930 & 67,2 \\
\hline Ввод жилья, ${ }^{2}$ & 1720 & 5276,8 & 306,8 \\
\hline ИТОГО & 646000 & 1558686 & 241,3 \\
\hline \multicolumn{2}{|c|}{ Всего по СУ-9 } \\
\hline Жилищное строительство & 1245000 & 2623284 & 210,7 \\
\hline Культурно-бытовое строительство & 786 & 68275 & 8.7 \\
\hline Промышленное строительство & 821000 & 252403 & 30,7 \\
\hline Ввод жилья, $м^{2}$ & 6955 & 9819,6 & 141,7 \\
\hline
\end{tabular}

Как видно из таблицы № 11, несмотря на острый дефицит строительных материалов и задержку обеспечения технической документации при общем недостатке жилья, план его строительства в 1964 году был выполнен трудовым коллективом на $230,7 \%$, а ввод составил $141,1 \%$. Тогда было построено

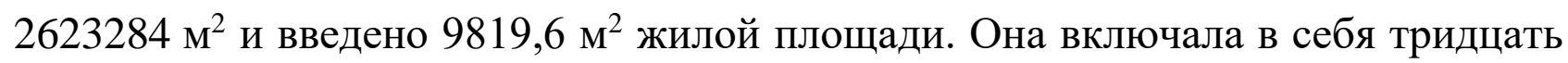
два восьмиквартирных дома с общей жилой площадью $7589 \mathrm{~m}^{2}$, восемь общежитий с площадью $2064 \mathrm{~m}^{2}$, четыре двухквартирных дома общей

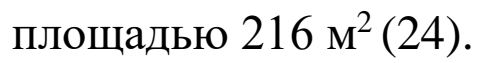

В разрезе заказчиков выполнение плана по вводу жилья в эксплуатацию выглядело следующим образом: строительство для «Главгеологии» по плану составляло $4575 \mathrm{~m}^{2}$, а выполнение - 3852,6 м², или 84,2\%. НПУ «Сургутнефть» заказывало по плану 660 м² $^{2}$ введено было 690 м2, или 104,5\%; соответственно

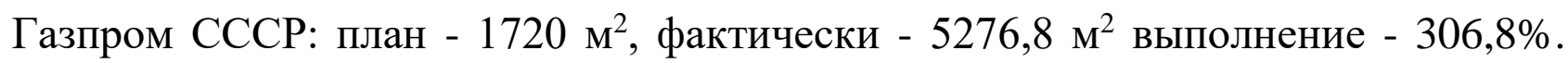
Собственное строительство по плану составляло $1720 \mathrm{~m}^{2}$, а было построено 5277 м² $^{2}$ или $306,8 \%$.

Столь высокие показатели жилищного строительства были связаны с тем, что план строительства промышленных объектов в 1964 году из-за несвоевременных поставок строительных конструкций был управлением свёрнут. Его выполнение составило 30,7\%. Тогда все имеющиеся в наличии производственные мощности были брошены на решение задач жилищного строительства. Это тем более было необходимо в силу того, что СУ-9 приняло в свои штаты в 1964 году более 800 рабочих и служащих.

Эти показатели были результатом инициативной самостоятельной работы его руководителя А. Кошмана, бравшего на себя ответственность за принятие нестандартных решений, граничащих с нарушениями порядка обеспечения вверенного ему строительного предприятия необходимой технической документацией и другими производственными инициативами, не согласованными с многочисленными ведомственными заказчиками и 
отраслевыми руководителями. Это становится особенно очевидным, если принять во внимание то, что субподрядная организация, какой являлось СУ-4 треста «Башнефтепромстрой», выполнила план жилищного строительства в Сургуге в том году всего на $34,5 \%$, т.е. при плане в размере $4000 \mathrm{~m}^{2}$ построила только $1150 \mathrm{M}^{2}(25)$.

Азы градостроения вынуждены были осваивать сами нефтяники. Сразу же после своего приезда они создали строительный участок под руководством С.С. Виниченко. Старший инженер В.А. Смыков выполнил топографические съемки и подготовил документы для отвода земли под застройку в противоположной от существовавшего поселка геологов части Сургута. Инженеры-нефтяники С. Пыриков, Т. Логинов, Е. Олейников на время стали проектировщиками нового жилого поселка нефтяников. Они дали дошедшие до нас сегодня яркие названия его первых улиц - Энтузиастов, Восход, проезд Молодежный, Нефтяников, Губкина.

Ввод в эксплуатацию стандартных брусовых домов позволял сургутянам достойно переносить суровые сибирские зимы. Возможно, застройка Сургута еще длительное время осуществлялась бы по этой «проектноградостроительной схеме», если бы не инициатива возведения первого пятиэтажного крупнопанельного дома начальника геофизической конторы В.С. Каткова и главного инженера М.С. Дубины. Комплект деталей дома был закуплен в Свердловске. Его сооружение взяла на себя бригада Н.Н. Щаденко.

Символично, что закладка бетона в его фундамент была произведена 26 июня 1965 года, то есть на следующий день после реорганизации рабочего поселка Сургут в город окружного подчинения. Через полтора года, в октябре 1966 года, в Сургуте, по адресу Набережный проспект, 46 был сдан в эксплуатацию первый в новом городе крупнопанельный дом (26), положивший начало отсчета индустриального каменного строительства в Сургуте.

Для деревянного жилищного строительства в Сургуте это был нестандартный, во многом решительный шаг, т.к. он был сделан в то время, когда «на верху» только решался вопрос о том, какими должны создаваться новые города, деревянными или капитальными, «каменными». Сохранился акт приемки первого крупнопанельного дома в Сургуте. Этот интересный документ свидетельствует о трогательном внимании создателей первенца сургутского городского каменного строительства к своему творению, их стремлении выполнить все формальности ввода его в эксплуатацию и тем самым обрести последователей в своем смелом начинании. 
Вслед за ним под руководством заместителя начальника производственного отдела Управления строительством Сургутской ГРЭС Алексея Белогорохова была сделана привязка на местности первого крупнопанельного дома в районе энергетиков. В 1969 году «Сургутгазстроем» в городе было построено 4 крупнопанельных пятиэтажных жилых здания сметной стоимостью 8733 рубля и общей площадью 7900 кв.м. (26). В микрорайоне строителей первое крупнопанельное пятиэтажное здание было возведено в 1971 году Строительным управлением № 22 во главе с В.Н. Пересыпкиным (27).

Город тянулся вверх. Вместе с ним росло его население. Его население стремительно росло. Опыт жилищного строительства в Сургуте свидетельствует о правильном подходе к расчету жилья на пионерном этапе освоения нефтегазовой территории и определению его номенклатуры с учетом возрастной структуры населения, которая представлена в таблице № 12 (28).

Таблица № 12

\section{Численность постоянного населения Сургута}

по отдельным возрастным группам

\begin{tabular}{|c|c|c|c|c|c|c|}
\hline \multirow{2}{*}{ Возраст, лет } & \multicolumn{6}{|c|}{ Годы } \\
\cline { 2 - 7 } & 1970 & 1979 & 1989 & 1991 & 1992 & 1993 \\
\hline 1 & 2 & 3 & 4 & 5 & 6 & 7 \\
\hline 0 & 636 & 2306 & 5312 & 3981 & 3527 & 2853 \\
\hline 1 & 596 & 2322 & 5913 & 4514 & 3944 & 34371 \\
\hline $0-2$ & 1834 & 6839 & 17364 & 13939 & 11927 & 10167 \\
\hline $3-5$ & 1825 & 6367 & 18514 & 18712 & 17651 & 15664 \\
\hline 6 & 655 & 2034 & 5889 & 6216 & 6221 & 6148 \\
\hline 7 & 677 & 1842 & 5196 & 6320 & 6109 & 6105 \\
\hline $8-13$ & 3859 & 9034 & 27084 & 30165 & 31719 & 32831 \\
\hline $14-15$ & 1048 & 12666 & 7241 & 8530 & 8644 & 8920 \\
\hline $16-17$ & 888 & 2628 & 5714 & 6830 & 7604 & 8313 \\
\hline $18-19$ & 1068 & 2476 & 3912 & 5572 & 5914 & 6469 \\
\hline $20-24$ & 3738 & 14646 & 17578 & 15606 & 14698 & 14864 \\
\hline $25-29$ & 3911 & 17855 & 34079 & 29844 & 26333 & 23167 \\
\hline $30-34$ & 5323 & 10907 & 33674 & 36126 & 35707 & 34419 \\
\hline $35-39$ & 3062 & 9109 & 26837 & 29634 & 30118 & 30717 \\
\hline $40-44$ & 2643 & 8560 & 14686 & 20884 & 22548 & 24016 \\
\hline $45-49$ & 1141 & 4622 & 11516 & 9528 & 9790 & 11169 \\
\hline
\end{tabular}


ГОРОДСКОЕ СТРОИТЕЛЬСТВО В ХАНТЫ-МАНСИЙСКОМ

АВТОНОМНОМ ОКРУГЕ - ЮГРЕ (к.1950-х - сер.1990-х г2.)

\begin{tabular}{|c|c|c|c|c|c|c|}
\hline $50-54$ & 707 & 3704 & 10006 & 12436 & 12679 & 11824 \\
\hline $55-59$ & 693 & 1311 & 4543 & 5124 & 5906 & 6986 \\
\hline $60-64$ & 398 & 736 & 3060 & 3821 & 3933 & 4002 \\
\hline $65-69$ & 244 & 573 & 1300 & 1818 & 2104 & 2449 \\
\hline 70 лет и старше & 297 & 815 & 2005 & 2340 & 2540 & 2615 \\
\hline ИТОГО & 34011 & 106724 & 250198 & 263445 & 262145 & 260845 \\
\hline $\begin{array}{c}\text { молодежь } \\
\text { трудоспособного } \\
\text { возраста }\end{array}$ & 9898 & 28782 & 81288 & 83882 & 82271 & 79835 \\
\hline $\begin{array}{c}\text { трудоспособное } \\
\text { население }\end{array}$ & 22782 & 75091 & 160192 & 168982 & 168249 & 168418 \\
\hline $\begin{array}{c}\text { старше } \\
\text { трудоспособного } \\
\text { возраста }\end{array}$ & 1315 & 2833 & 8718 & 10581 & 11625 & 12592 \\
\hline
\end{tabular}

Из таблицы видно, что основным контингентом рабочих кадров являлись молодые люди в возрастном диапазоне 20-40 лет. В этом возрасте люди приезжали преимущественно с ознакомительными целями либо холостыми, либо без семей. В 1970-1980-е гг. эта возрастная группа составляла почти 50\% населения города, а средний возраст населения равнялся 26,3 годам. Многочисленные «малосемейки» и «моспроекты» в этих условиях приобретали особенно важное значение для выполнения установок руководящих органов партии и государства по закреплению кадров на севере и расселению нефтяников, газовиков и энергетиков в благоустроенные квартиры.

Нижневартовский городской комитет партии, городской исполнительный комитет Совета народных депутатов и городской комитет ВЛКСМ в 1988 году выступили с интересной инициативой. Ими был создан «Организационный комитет молодежного жилищного комплекса». В 1988-1997-е гг. он осуществлял активную работу по строительству жилых домов и объектов социального, культурно-бытового и спортивного назначения, созданию единого комплекса, расположенного по месту жительства и решающего воспитательные, бытовые и социально-экономические проблемы молодежи. К сожалению, в 1997 году в связи с утратой ВЛКСМ своей ведущей роли в молодежном движении страны этот комитет прекратил свое существование (29).

Однако опыт расселения молодежи в начальный период градостроительства в ХМАО-Югре не был утрачен и приобрел своеобразную 
интерпретацию. Тогда дома гостиничного типа с малогабаритными квартирами, напоминающие общежития «трехлистники», способные затем трансформироваться в традиционные квартирные жилища, являлись объектом пристального внимания руководителей ведомств и местных хозяйственных организаций, участвующих в его застройке. Не случайно то, что городские исполнительные Советы депутатов трудящихся слабо реагировали на неоднократные команды центральных органов власти и Тюменского облисполкома о запрете проектирования с 1972 года и строительства с 1973 года жилых домов по устаревшим сериям. 125-я серия «трехлистников» даже в 1985 году продолжала выпускаться в объеме 16 тыс. м³ (30).

Объемы строительства домов переходного типа, способных по мере образования самостоятельных молодежных семей трансформироваться в полнометражные квартиры, незначительно отставали от масштабов их возведения и на многие годы явились залогом решения кадрового вопроса в промышленных отраслях. Конкретные объемы жилищного и социальнобытового строительства в городах и поселках Тюменской и Томской областей для удовлетворения нужд геологов и нефтяников, строителей и транспортников, газовиков и энергетиков были определены в Постановлении Совета Министров СССР № 919 от 21 декабря 1971 года и совместном Постановлении ЦК КПСС и Совета Министров СССР № 123 от 9 февраля 1978 года. В указанных постановлениях ведущая роль в строительстве жилья и объектов соцкультбыта отводилась сложившимся центрам нефтяной и газовой добычи. И они постоянно выполняли свой долг перед страной. Сургутские градостроители в девятой пятилетке (1971-1975 гг.) суммарно освоили 434,3 млн. рублей, в том числе в непроизводственном строительстве - 58,5 млн. рублей. За это время в городе было построено и введено в эксплуатацию 98,0 тыс. м² жилья, больничный комплекс на 240 коек и поликлиника на 500 посещений, детсадов на 510 мест, школ на 1280 учащихся, значительное число объектов общепита, торговли и коммунального назначения (31). 
Таблица № 13

\section{Общий объем жилищного строительства в Сургуте}

\section{(фактически произведенного)}

\begin{tabular}{|c|c|c|c|c|c|c|c|c|c|c|c|c|c|c|}
\hline Группа & Параметры & $\begin{array}{l}\text { Ед. } \\
\text { изм }\end{array}$ & ڤे & $\stackrel{?}{\stackrel{2}{\Omega}}$ & $\hat{ล}$ & $\stackrel{N}{a}$ & $\stackrel{\Re}{\sigma}$ & $\stackrel{+}{\stackrel{ \pm}{\Omega}}$ & $\stackrel{n}{a}$ & $\begin{array}{l}\stackrel{0}{2} \\
\vdots\end{array}$ & 今ิ & $\stackrel{\infty}{5}$ & $\stackrel{\bar{\infty}}{\varrho}$ & $\stackrel{\varrho}{\varrho}$ \\
\hline \multirow{3}{*}{ 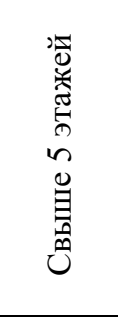 } & $\begin{array}{c}\text { Сметная } \\
\text { стоимость }\end{array}$ & $\begin{array}{l}\text { тыс. } \\
\text { руб. }\end{array}$ & & & & & & $\stackrel{q}{\infty}$ & 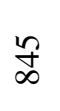 & $\stackrel{尺}{\stackrel{2}{I}}$ & $\stackrel{8}{ \pm}$ & $\begin{array}{l}\infty \\
\text { तె }\end{array}$ & $\frac{8}{m}$ & $\frac{8}{\infty}$ \\
\hline & $\begin{array}{c}\text { Количество } \\
\text { зданий }\end{array}$ & шт. & & & & & & - & - & $\nabla$ & $N$ & $n$ & $\ddot{\lambda}$ & $n$ \\
\hline & $\begin{array}{c}\text { Полезная } \\
\text { площадь }\end{array}$ & $\begin{array}{l}\text { тыс. } \\
\text { м3 }\end{array}$ & & & & & & $\stackrel{m}{\rightarrow}$ & $\stackrel{\sim}{-}$ & $\infty$ & $\stackrel{\infty}{\infty}$ & $\hat{\vec{i}}$ & $\stackrel{\infty}{a}$ & $\underset{\text { f }}{\stackrel{n}{d}}$ \\
\hline \multirow{3}{*}{ 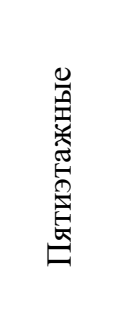 } & $\begin{array}{c}\text { Сметная } \\
\text { стоимость }\end{array}$ & $\begin{array}{l}\text { тыс. } \\
\text { руб. }\end{array}$ & 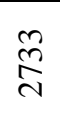 & $\underset{\infty}{ \pm}$ & $\begin{array}{l}\text { ڤิ } \\
\text { ลิ }\end{array}$ & 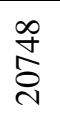 & ڤิ & $\begin{array}{l}\vec{a} \\
\infty \\
\infty\end{array}$ & $\begin{array}{l}\stackrel{8}{0} \\
\stackrel{9}{m}\end{array}$ & $\stackrel{q}{g}$ & 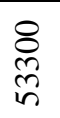 & 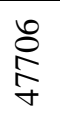 & 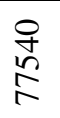 & 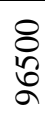 \\
\hline & $\begin{array}{c}\text { Количество } \\
\text { зданий }\end{array}$ & шт. & $\nabla$ & $a$ & $\approx$ & ส & $m$ & $n$ & $\stackrel{\infty}{\sim}$ & $\vec{m}$ & F & 오 & $\stackrel{n}{\sim}$ & in \\
\hline & $\begin{array}{c}\text { Полезная } \\
\text { площадь }\end{array}$ & $\begin{array}{l}\text { тыс. } \\
\text { M3 }\end{array}$ & $\stackrel{a}{r}$ & $\stackrel{\nabla}{\vec{\lambda}}$ & $\ddot{\infty}$ & $\cong$ & $\stackrel{\text { I }}{\Xi}$ & $\stackrel{\infty}{=}$ & $\stackrel{+}{n}$ & $\begin{array}{l}\infty \\
\infty \\
\infty\end{array}$ & $\stackrel{m}{m}$ & 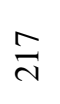 & $\begin{array}{l}\infty \\
\vdots \\
0 \\
e\end{array}$ & 离 \\
\hline \multirow{3}{*}{ 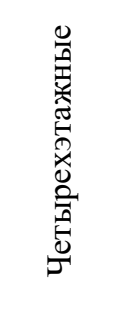 } & $\begin{array}{l}\text { Сметная } \\
\text { стоимость }\end{array}$ & $\begin{array}{l}\text { тыс. } \\
\text { руб. }\end{array}$ & & & & & कृ & & & & & $\stackrel{R}{n}$ & & \\
\hline & $\begin{array}{c}\text { Количество } \\
\text { зданий }\end{array}$ & шт. & & & & & - & & & & & $\sim$ & & \\
\hline & $\begin{array}{c}\text { Полезная } \\
\text { площадь }\end{array}$ & $\begin{array}{c}\text { тыс. } \\
\text { м3 }\end{array}$ & & & & & $\stackrel{\Xi}{\rightarrow}$ & & & & & $\bar{i}$ & & \\
\hline \multirow{3}{*}{ 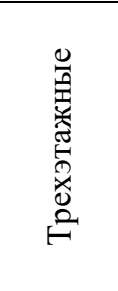 } & $\begin{array}{c}\text { Сметная } \\
\text { стоимость }\end{array}$ & $\begin{array}{l}\text { тыс. } \\
\text { руб. }\end{array}$ & $\hat{q}$ & $\tilde{8}$ & 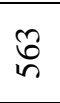 & $\begin{array}{l} \pm \\
\infty\end{array}$ & ๙্ & $\stackrel{8}{8}$ & $\stackrel{\infty}{\alpha}$ & & & & & \\
\hline & $\begin{array}{c}\text { Количество } \\
\text { зданий }\end{array}$ & шт. & - & $m$ & $m$ & $\nabla$ & - & - & $\sim$ & & & & & \\
\hline & $\begin{array}{c}\text { Полезная } \\
\text { площадь }\end{array}$ & $\begin{array}{c}\text { тыс. } \\
\text { м3 }\end{array}$ & $\stackrel{2}{2}$ & $\stackrel{\mathrm{N}}{\mathrm{N}}$ & ส & $\stackrel{\infty}{\stackrel{\infty}{+}}$ & & $\triangleright$ & $\vec{i}$ & & & & & \\
\hline \multirow{3}{*}{ 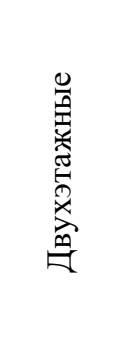 } & $\begin{array}{c}\text { Сметная } \\
\text { стоимость }\end{array}$ & $\begin{array}{l}\text { тыс. } \\
\text { руб. }\end{array}$ & $\underset{\sigma}{ \pm}$ & $\stackrel{\infty}{\infty}$ & $\frac{\infty}{\infty}$ & $\stackrel{P}{+}$ & 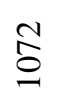 & $\vec{n}$ & $\frac{n}{n}$ & $\stackrel{?}{I}$ & $\infty$ & $\stackrel{\infty}{\Delta}$ & \&̊ & 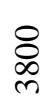 \\
\hline & $\begin{array}{c}\text { Количество } \\
\text { зданий }\end{array}$ & шт. & $\Xi$ & $r$ & $a$ & $m$ & $r$ & - & - & & $m$ & $\infty$ & 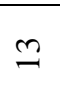 & 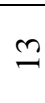 \\
\hline & $\begin{array}{c}\text { Полезная } \\
\text { площадь }\end{array}$ & $\begin{array}{l}\text { тыс. } \\
\text { м3 }\end{array}$ & $\stackrel{2}{r}$ & $\hat{m}$ & $\nabla$ & î & $\nabla$ & $\exists$ & $\exists$ & $\bar{i}$ & $\stackrel{m}{m}$ & $\hat{\infty}$ & $\stackrel{\Delta}{\Xi}$ & $\stackrel{0}{\infty}$ \\
\hline \multirow{3}{*}{ 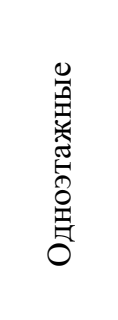 } & $\begin{array}{c}\text { Сметная } \\
\text { стоимость }\end{array}$ & $\begin{array}{l}\text { тыс. } \\
\text { руб. }\end{array}$ & & & & & & & & & & 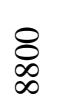 & & \\
\hline & $\begin{array}{c}\text { Количество } \\
\text { зданий }\end{array}$ & шт. & & & & & & & & & & $n$ & & \\
\hline & $\begin{array}{c}\text { Полезная } \\
\text { площадь }\end{array}$ & $\begin{array}{l}\text { тыс. } \\
\text { м3 }\end{array}$ & & & & & & & & & & $\stackrel{+}{i}$ & & \\
\hline
\end{tabular}




\begin{tabular}{|c|c|c|c|c|c|c|c|c|c|c|c|c|c|c|}
\hline \multirow{3}{*}{ 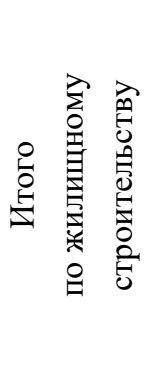 } & $\begin{array}{c}\text { Сметная } \\
\text { стоимость }\end{array}$ & $\begin{array}{l}\text { тыс. } \\
\text { руб. }\end{array}$ & $\frac{\text { i }}{m}$ & $\frac{n}{n}$ & $\begin{array}{l}\stackrel{2}{\infty} \\
\stackrel{2}{N}\end{array}$ & ָิ & m & $\begin{array}{l}n \\
\text { ñ } \\
\text { nे }\end{array}$ & 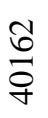 & 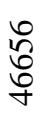 & \begin{tabular}{l}
8 \\
\multirow{0}{0}{} \\
$\qquad$
\end{tabular} & $\frac{n}{n}$ & $\stackrel{\text { g }}{\stackrel{2}{=}}$ & $\begin{array}{l}8 \\
\text { ¿ } \\
\text { ते }\end{array}$ \\
\hline & $\begin{array}{c}\text { Количество } \\
\text { зданий }\end{array}$ & шт. & $\stackrel{\sim}{\sim}$ & $\stackrel{9}{ }$ & $\bar{\lambda}$ & ৯े & $F$ & $m$ & $\stackrel{\infty}{m}$ & $F$ & in & $\stackrel{n}{=}$ & $\Xi$ & $\stackrel{\infty}{=}$ \\
\hline & $\begin{array}{c}\text { Полезная } \\
\text { площадь }\end{array}$ & $\begin{array}{c}\text { тыс. } \\
\text { м3 }\end{array}$ & $\vec{I}$ & กे & $\stackrel{\infty}{\infty}$ & $\stackrel{\vartheta}{I}$ & 守 & iे & $\stackrel{g}{ \pm}$ & $\begin{array}{l}m \\
\stackrel{g}{g}\end{array}$ & $\begin{array}{l}0 \\
\text { i } \\
\text { m }\end{array}$ & 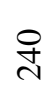 & $\stackrel{\vartheta}{\gamma}$ & $\begin{array}{l}0 \\
\dot{f} \\
f\end{array}$ \\
\hline \multirow{3}{*}{ 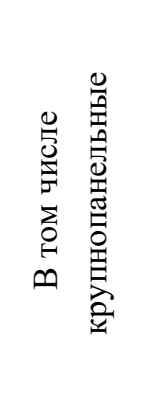 } & $\begin{array}{c}\text { Сметная } \\
\text { стоимость }\end{array}$ & $\begin{array}{l}\text { тыс. } \\
\text { руб. }\end{array}$ & $\stackrel{m}{\stackrel{n}{v}}$ & $\stackrel{尺}{\stackrel{N}{\infty}}$ & $\begin{array}{l}\text { ô } \\
\stackrel{n}{2}\end{array}$ & 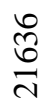 & $\frac{i}{\sigma}$ & \begin{tabular}{l}
\multirow{n}{n}{} \\
$\stackrel{n}{n}$
\end{tabular} & $\underset{\vec{m}}{\stackrel{a}{m}}$ & $\begin{array}{l}\text { 守 } \\
\text { i }\end{array}$ & $\begin{array}{l}\underset{8}{2} \\
\text { nn } \\
n\end{array}$ & 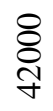 & $\begin{array}{l}\stackrel{2}{2} \\
\text { }\end{array}$ & \\
\hline & $\begin{array}{c}\text { Количество } \\
\text { зданий }\end{array}$ & шт. & $\nabla$ & $\simeq$ & 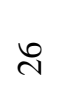 & 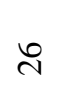 & $\stackrel{\infty}{\infty}$ & $m$ & $\stackrel{n}{m}$ & ల & 于 & $\mathscr{f}$ & 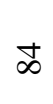 & $\curvearrowleft$ \\
\hline & $\begin{array}{c}\text { Полезная } \\
\text { плоишь }\end{array}$ & $\begin{array}{c}\text { тыс. } \\
\text { м3 }\end{array}$ & $\hat{\sigma}$ & $\begin{array}{l}0 \\
\text { aे } \\
\text { ה }\end{array}$ & $\hat{8}$ & $\begin{array}{l}\infty \\
\stackrel{\infty}{\varrho} \\
\underline{=}\end{array}$ & $\underset{ \pm}{ \pm}$ & ஜิ & $\stackrel{\infty}{n}$ & $\begin{array}{l}+ \\
\infty \\
\infty\end{array}$ & m. & $\stackrel{\circ}{2}$ & ले & $\overline{\mathbb{\delta}}$ \\
\hline 突 & $\begin{array}{c}\text { Сметная } \\
\text { стоимость }\end{array}$ & $\begin{array}{l}\text { тыс. } \\
\text { руб. }\end{array}$ & & & & & & & & & & & $\begin{array}{l}\text { 告 } \\
\text { ñ }\end{array}$ & \\
\hline 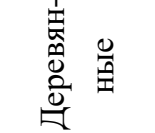 & $\begin{array}{c}\text { Сметная } \\
\text { стоимость }\end{array}$ & $\begin{array}{l}\text { тыс. } \\
\text { руб. }\end{array}$ & & & & & & & & & & & f & \\
\hline
\end{tabular}

Как видно из таблицы № 13, в Сургуте до 1974 года домов выше 5 этажей не строилось. Доминировало пятиэтажное строительство, которое после ввода Сургутского домостроительного комбината продолжало наращивать свои объемы. Четырехэтажных домов в Сургуте практически не строили, двухэтажное, трёхэтажное строительство к 1975 году было заторможено.

В дополнение к таблице скажем, что из 24 строительных организаций города в середине 1970-х гг. больше половины успешно справлялись с выполнением программ подрядных работ. Среди них передовиками являлись СУ-8, СУ-9, Управление строительством ГРЭС, СУ-904, СМП-33О, СК-53, СМУ-4, СМУ-6, СУ-16 и другие строительные организации, которые значительно перевыполняли план строительно-монтажных работ. В 1977 году, например, строительные организации города и района план строительномонтажных работ выполнили на $112 \%$. Они освоили 187,6 млн. рублей капитальных вложений, в том числе сверх плана 5,5 млн. рублей, ввели в строй основных фондов на 171 млн. рублей. В Сургуте и районе было введено в

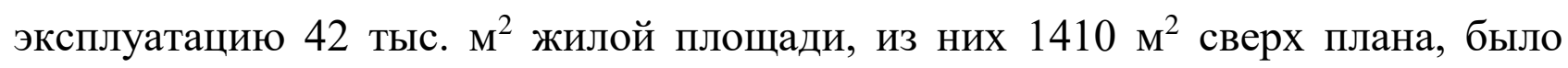


построено клубов на 800 посадочных мест, профессионально-технических училищ на 600 учащихся (32).

Их усилиями в 1977 году, по сравнению с предыдущим годом, освоение капитальных вложений возросло на 45\%. Ежегодные объемы полезной площади построенного жилья в Сургуте динамично росли и составили в 1981

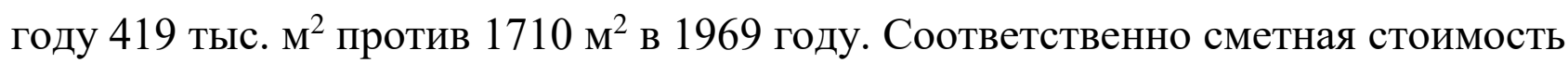
строительства возросла с 3120 руб. до 113140 руб. в 1981 году. В этом году было построено 111 зданий, причем 84 из них были возведены в крупнопанельном исполнении, в то время как в 1969 году соответственно только 26 и 4 (33).

Стремительные темпы роста ввода жилья актуализировали вопросы качества строительства. Они неоднократно выносились на обсуждение городского Совета депутатов трудящихся, им уделялось максимальное внимание на заседаниях городского комитета КПСС, большинство решений успешно выполнялось. В среднем на возведение типового «ленпроекта» в Сургуте при хорошем раскладе уходило четыре месяца. Однако часто дома возводили значительно быстрее. В условиях жесткого дефицита жилья и учреждений соцкультбыта заказчики вынуждены были принимать объекты с серьезными недоделками. Первый крупнопанельный дом в микрорайоне строителей вводился с серьезными нарушениями строительных норм и правил. Его монтаж, который осуществляли рабочие СУ-22, производился без соблюдения допусков, разрешенных СНиПами, лестничные площадки были установлены на самодельно выполненные опоры, не была произведена металлизация сварных соединений, плохо утеплены и гидроизолированы стыки между панелями. Новый комплекс ГПТУ-17 имел ряд серьезных дефектов, связанных с выполнением технических условий и недопустимо низким качеством строительных работ. В нем был проморожен фундамент корпуса теоретических занятий, в результате чего внутренняя стена просела сильнее наружных на 10-12 см. На еще не сданном объекте уже частично отвалилась облицовка из силикатного кирпича. В 1983 году Миннефтегазстрою для отчетности о выполнении плана за уходящий год не хватало вводимых метров жилья. Тогда при условии сдачи дома не позднее января 1984 года домостроительному комбинату было разрешено строительство пятиэтажного 86-квартирногодома для своих работников. Построенное в спешке здание было сдано в эксплуатацию 10 января 1984 года. Дом стоит до сих пор. 
Наряду с форсированным строительством имелись случаи, когда сроки других объектов города затягивались. На них городской комитет КПСС и исполнительный комитет городского Совета реагировали особенно остро. На IX сессии Сургутского городского совета депутатов трудящихся в 1971 году серьезной критике подвергся ряд хозяйственных руководителей в связи с тем, что Дом культуры геологов и нефтяников строится с 1966-1967 гг. Шестой год строится тубдиспансер, столько ж е прачечная на 2000 кг белья. Руководство треста «Сургутгазстрой» упорно не желает начинать строительство поликлиники в микрорайоне геологов, по их вине чрезвычайно медленно идет строительство больничного комплекса в поселке НПУ (34).

При таком низком качестве и предельной интенсификации строительства в городе на протяжении всего исследуемого периода жилой площади недоставало. В 1976 году на одного жителя Сургута приходилось в среднем $5,6 \mathrm{~m}^{2}$ жилой площади при норме по стране $9 \mathrm{~m}^{2}$. В городское строительство было вложено в 4 раза меньше финансовых средств, чем это требовалось в соответствии с численностью населения. Только для переселения трудящихся из вагонов и балков требовалось более 50 тыс. м² жилья. В январе-ноябре 1977 года в редакцию городской газеты «К победе коммунизма» поступило 240 жалоб трудящихся, из которых 74 были связаны с бытовой неустроенностью, перебоям с горячей водой, неисправностями инженерных сетей, нерешенностью вопросов благоустройства.

У некоторых сургутян жилищное положение было катастрофическим. Так, например, пенсионерка М.Р. Найда писала в Тюменский обком КПСС (пунктуация и орфография сохранены): «Прошу настоящей жалобой все же мне помочь нельзя так больше издеваться Сургутскому горкому... все обманные сроки прошли... живешь все в этой караулке в ней живу я с 1962 года и в ней не было никакого ремонта... я наверняка замерзну в ней она кругом вся дырявая и печь все время приходится ремонтировать... я советский человек проработавши свои лета работала все силы отдавала, но теперь престигла старость да болезнь не кому не стала нужна правда пенсию дали хорошую не жалуюсь...» (35).

Некоторые горожане, проживавшие в балках и не имевшие перспективы улучшения условий своего существования, самостоятельно решали свой жилищный вопрос. В Сургуте имели место случаи поджогов ветхого жилья. Например, отчаявшиеся жители базового городка СУ-28 подожгли его. Погорельцы сразу получили квартиры (36). Таким образом, дефицит 
благоустроенного жилья в городе Сургуте оставался острой социальной проблемой.

В предыдущей главе мы обращали особое внимание на слабую техническую оснащенность и недостаточную энерговооруженность строительных организаций ХМАО-Югры. Другой немаловажной проблемой развития строительной отрасли округа являлся острый дефицит рабочих кадров. Госкомитет Совета Министров РСФСР по профессиональнотехническому образованию по согласованию с Министерством газовой промышленности в III квартале 1968 года направил строительным организациям «Главтюменнефтегазстроя» 570 выпускников профтехучилищ Тюменской области (37). Однако действующие в области профтехучилища строительного профиля не удовлетворяли потребности строительных организаций в рабочей силе.

В 1968 году Тюменский обком КПСС в обращении к председателю Госкомитета Совета Министров СССР по профессионально-техническому образованию П.И. Кирпичникову адресовал просьбу «рассмотреть возможность направления из Татарской и Башкирской АССР, а также из других областей и регионов Российской Федерации молодых рабочих строительных специальностей, оканчивающих ПТУ в 1968 году, для работы в строительных организациях нефтяных районов Тюменской области «Главтюменнефтегазстроя» Министерства газовой промышленности СССР», гарантируя создание всех необходимых социальных условий для работы (38).

Основной формой комплектования кадров специального строительного главка в Западной Сибири являлось трудоустройство самими предприятиями. Оно охватывало $75 \%$ всех принимаемых на работу. Однако обещания их руководителей относительно «создания необходимых условий для труда и отдыха» оказывались призрачными. По расчетам «Гипрогора» в Сургуте должно было строиться ежегодно 60000 тыс. м² жилья и определенные нормами соответствующие им культурно-бытовые объекты. Фактически того и другого в Сургуте строилось в 2 раза меньше. Обеспеченность жильем в нем составляла в 1969 году 5,5 м² на человека, детскими учреждениями - 54\%, столовыми - 67\%, кинотеатрами - 68\%, детскими садами - 54\%. По этой причине текучесть кадров в 1969 году превышала 66\%. Тогда в город прибыло 8900 человек, а уехало 5400 (39).

Важным источником рабочей силы строительных предприятий ХМАО-Югры являлся «спецконтингент». 20 июня 1967 года было принято 
решение об открытии в Сургуте новой исправительно-трудовой колонии строгого режима ОМЗ УООП Тюменского облисполкома и дислоцировании ее на восточной окраине, в 7 км от центра города, с лимитом наполнения 1100 заключенных. В жилой зоне для размещения заключенных планировалось построить общежитие на 1100 человек, столовую-клуб на 350 посадочных мест, помещение камерного типа на 50 человек в кирпичном исполнении, банюпрачечную на 25 человек, КПП с комнатами свидании, амбулаторию-санчасть на 15 коек, склад личных вещей, магазин, профтехучилище и школу на 300 учащихся (40).

«Зону-лагерь» заключенных разместили на месте, где впоследствии построили ГПТУ № 17. Весь прилегающий к ней небольшой район строителей в народе называли «Бухенвальдом». Здесь, на месте нынешней улицы 30 лет Победы, проживали в бараках условно освобожденные заключенные (41). Всего же на стройках севера работало свыше 25 тыс. рабочих из числа заключенных и условно освобожденных (42).

Их труд широко использовался в ходе строительства завода железобетонных конструкций, годовая мощность которого составляла 70 тыс. м., комбината панельного домостроения с объемом производства

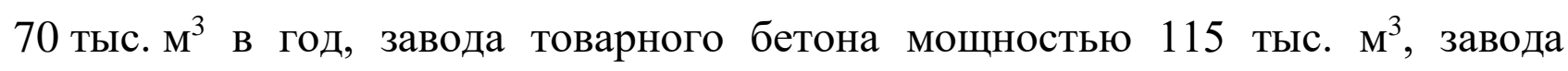
керамзитового гравия» с производством 100 тыс. м³ этого строительного материала и выпуском 100 тыс. м ${ }^{3}$ керамзитобетонных изделий промзданий. Труд «спецконтингента» широко применялся в Сургуте на сборке брусчатых домов, а также в ходе строительства и ввода в строй кирпичного завода в Локосово (43).

Для охраны колонии и производственных участков формировалась отдельно дислоцированная команда, численностью 122 человек, из которой 24 человека определялось в надзорную службу за счет дополнительной списочной численности.

Личный состав планировалось разместить в строящемся военном городке с периметром 1500 метров. Он включал в себя казарму на 100-150 человек, питомник служебных собак с вольером на 10 собак, гараж на 3 машины, баню-прачечную на 5 мест, склад вещевого, продовольственного и инженерного имущества площадью $52 \mathrm{~m}^{2}$, овощехранилище объемом 50 тонн, КПП на 1 пост с гауптвахтой, ограждение военного городка (44).

Для размещения начальствующего офицерского, сержантского составов, вольнонаемных работников, а также хозяйственного обслуживания личного 
состава конвойной охраны и заключенных было решено построить жилых домов на 70 квартир, овощехранилище на 250 тонн, гараж на 10 автомашин, продовольственно-вещевой склад площадью $300 \mathrm{~m}^{2}$, штаб подразделения на 40 человек (45).

Летом того же года Сургут принял около полутора тысяч условно досрочно освобожденных граждан. «Среди них были администраторы, швейники, парикмахеры и даже распространители театральных билетов, а вот для строительства, где их планировалось использовать, специалистов было мало», - вспоминал П.А. Мунарев (46). Даже в 1971 году на Сургутском домостроительном комбинате, полностью укомплектованном рабочими из числа «спецконтингента» исправительно-трудовой колонии, уровень их квалификации и организованности не соответствовал требованиям производства. На заводе железобетонных изделий, который в феврале 1971 года был создан в составе домостроительного комбината, разряд выполняемых работ составлял 3,8, а квалификационный разряд рабочих - только 3,3 (47). При этом если на заводе за счет осужденных исправительно-трудовой колонии штат рабочих был укомплектован полностью, то в обеспечении рабочими причалов и монтажных участков ощущался острый дефицит кадров. На участке комплектации, например, недоставало более 30 рабочих. С учетом расширения монтажных работ комбинату в ближайшее время должно было потребоваться еще до 30 человек вольнонаемных рабочих (48).

Особенно остро городское строительство ХМАО-Югры испытывало потребность в инженерно-технических работниках. Службы Сургутского домостроительного комбината, например, в мае 1971 г. были обеспечены ИТР только на 70-75\%. Совершенно не укомплектованы были такие важные производственные отделы, как отдел главного механика, организации труда и зарплаты, комплектации и снабжения, бухгалтерии, монтажного участка и участка технической комплектации. Для нормальной организации труда на комбинате требовалось дополнительно 60 инженерно-технических работников, в том числе 24 линейных. В их штате был высок удельный вес работников, не имеющих специального образования, остро ощущался дефицит специалистов с высшим образованием (49).

На заводе железобетонных изделий были не укомплектованы плановый отдел, конструкторский и главного энергетика, а также бухгалтерия и лаборатория. В цехах не хватало мастеров и механиков (50). 


\section{ГОРОДСКОЕ СТРОИТЕЛЬСТВО В ХАНТЫ-МАНСИЙСКОМ АВТОНОМНОМ ОКРУГЕ - ЮГРЕ (к.1950-х - сер.1990-х г2.)}

Весьма своеобразно начиналось строительство ДК «Нефтяник» в Сургуте. Как вспоминали очевидцы, строительство дворца, где навсегда должен был поселиться дух свободного творчества, замышлялось нефтяниками буквально в первые дни создания НПУ «Сургутнефть». Их мечтам суждено было сбыться только в начале семидесятых годов, когда развернули строительную площадку в центре микрорайона нефтяников. «Вырытый под сваи котлован обнесли колючкой, поставили сторожевые вышки и ...привезли заключенных» (51).

Вопреки мнению некоторых авторов о низком качестве работы «зеков», в литературе существует и другая точка зрения. Г. Северный пишет, что «они оказались на редкость трудолюбивыми. За четыре года им удалось в 4 раза увеличить объемы выпускаемого железобетона» на сургутском заводе (51). Противоречивую оценку давал им П.А. Мунарев. Выступая публично на IX сессии Сургутского райисполкома в 1964 году, он призывал областное руководство «не присылать в Сургут этих «тунеядцев», в то же время в своих воспоминаниях писал: «Многие «условники», как их тогда называли, стали мастерами своего дела. Такими, например, как бригадир плотников Герман Степанович Авдюков, награжденный по итогам работы в девятой пятилетке Орденом Трудового Красного Знамени» (52).

Вместе с тем следует отметить, что использование «спецконтингента» исправительно-трудовой колонии создавало негативные прецеденты в организации производства. Руководство Сургутского домостроительного комбината длительное время не могло добиться, чтобы работа на комбинате начиналась в 8 часов утра, а не в 9 из-за позиции администрации колонии. «Ее, по мнению Сургутского городского комитета КПСС в 1971 году, вообще не интересует, работают люди или нет. Лишь бы была выработка, то есть определенная зарплата в день. А что сделано, сколько заформовано изделий, что делали рабочие, колонию не интересует. Интересы дела требуют, чтобы руководство ИТК отвечало за освоение мощностей на домостроительном комбинате наравне с его руководством» (53).

Еще более серьезными были правоохранительные последствия использования этого контингента строителей, так как оно создавало сложную криминогенную обстановку в новых городах и поселках. Во время высадки ночью на пристани Мегиона подвергся смертельной опасности нападения досрочно освобожденных заключенных руководитель «Главтрубопроводстроя», будущий министр строительства нефтяной и газовой промышленности В.Г. Чирсков и сопровождающие его двое мужчин и две 
женщины. Только своевременное прибытие вооруженных милиционеров позволило остановить разъяренных утоловников (54).

Трагические события произошли в Урае. Там в ночь под Новый год после внезапного сорокаградусного похолодания размещенные в палатках досрочно освобожденные заключенные предприняли попытки самовольного расселения и захват домов города. В сводке райисполкома отмечалось: «За ночь шесть жителей города были зарезаны» (55).

В Сургуте использование труда условно освобожденных граждан постепенно сокращалось. Было услышано искреннее выступление П.А. Мунарева на X пленуме Сургутского городского комитета КПСС 31 января 1969 года: «На стройки нашего города едет очень много людей - есть хорошие и плохие люди, но к нам еще организованным порядком направляют тунеядцев из других городов Советского Союза, которые мешают создавать нормальные условия труда и быта» (56). После вынужденного привлечения таких строителей в ходе введения в эксплуатацию построенного домостроительного комбината они были заменены молодыми рабочими, прибывшими по комсомольскому призыву в основном с Украины. В целом на стройках севера Западной Сибири и обустройстве ее месторождений во второй половине 1970-х гг. использование спецконтингента было сведено к минимуму. В Сургуте на заводе железобетонных изделий перевод работающего спецконтингента на вольнонаемный состав начался в 1978 году (57). Основной состав трудовых ресурсов, занятых в отраслях строительства и промышленности формирующегося нефтегазового комплекса, стали представлять набранные по оргнабору рабочие и специалисты из центральных нефтедобывающих регионов страны (58).

Недостаток кадров строителей города и сложность природноклиматических условий компенсировались самоотверженным трудом таких жителей Сургута, как ветераны домостроительного комбината О.Н. Бердюгин, В.В. Крукавец, В.Н. Глущенко, Г.А.Крашенина, А.И. Сливкина, Е.В. Скорик, Н.Н. Ткачева. Благодаря напряженному труду рабочих строительных организаций в 1990 году удалось ввести в строй 201,2 тыс. м² жилья, обеспечивая темпы его роста, вдвое опережающие средние по стране (59).

Сургутские строители демонстрировали образцы высокопроизводительного труда. В 1976 году семь из восьми бригад маляров домостроительного комбината обеспечивали ежедневную выработку от полутора до двух с лишним норм. По две с лишним нормы в день выполняли 
бригады плотников Г.П. Гурина и Г.М. Аржаховского, монтажников К.Ш. Маеровича. Бригада монтажников С.П. Строцева в день монтировала $4,7 \mathrm{~m}^{2}$ полезной площади на одного рабочего при $1,1 \mathrm{~m}^{2}$ по плану. Она была близка к наивысшему показателю, достигнутому в южных районах страны, $5.2 \mathrm{~m}^{3}$ (60). Выработка строительно-монтажных работ на одного работающего составила в 1976 году 14,6 тыс. рублей при плане 13,5 тыс. рублей. Выпуск деталей крупнопанельного домостроения в 1976 году составил 189,5 тыс. м² при плане 187,0 тыс. м² (61).

Столь высокие производственные показатели стали возможными благодаря хорошо налаженному социалистическому соревнованию. На Сургутском домостроительном комбинате по решению парткома и объединенного постройкома во всех подразделениях были приняты повышенные социалистические обязательства и разработаны условия их выполнения. Согласно им победителем в социалистическом соревновании признавался коллектив, выполнивший на каждого человека не менее полутора дневной нормы с хорошим качеством работ, соблюдением техники безопасности и охраны труда. Итоги работы подводились ежедекадно специально созданным штабом.

Результаты соревнования доводились до сведения рабочих непосредственно на строительных объектах. Коллективам-победителям вручались денежные премии и почетные грамоты. В честь бригадпобедительниц, добившихся наивысшей выработки, ежедневно на стройплощадке поднимался красный флаг. На всех вводимых домах вывешивались призывные плакаты и стенды с указанием бригады, работающей на данном объекте, сроков начала и окончания работ, сдачи объекта.

В 1976 году за выполнение повышенных социалистических обязательств 13 коллективов были награждены Почетными грамотами комбината и денежными премиями, в их честь были проведены митинги, а шесть бригад отделочников и монтажников награждены Почетными грамотами объединения «Сибжилстрой» и обкома профсоюза «Миннефтегазпромстроя» с вручением крупных денежных премий (62). По итогам работы 1976 года завод железобетонных изделий, автобаза № 5, управление механизации № 6, строительно-монтажное управление № 3, специализированное управление № 42 были представлены к конкурсу на соискание классных мест в областном и всесоюзном социалистическом соревновании. Все они заняли призовые места и были награждены Министерством строительства предприятий нефтяной и газовой промышленности СССР (63). В 1976 году социалистическим 
соревнованием было охвачено 3116 рабочих Сургутского домостроительного комбината под девизами: «Ни одного отстающего рядом, ни одного отстающего коллектива!», «Работать по методу Басова, без травм и аварий!». В том году 606 человек добились высокого звания «Ударник коммунистического труда», в том числе 167 рабочих получили его в составе 11 бригад коммунистического труда» (63).

Во второй половине 1960-х гг. большую роль в обеспечении рабочими кадрами строительства в новых городах на севере Тюменской области начал играть Всесоюзный студенческий отряд. 30 марта 1965 года ЦК ВЛКСМ принял постановление о направлении студенческих отрядов в районы нефтяных и газовых месторождений. В 1967 году тюменский областной студенческий отряд включал в себя 8100 представителей 83 вузов из 27 городов России и Украины (64). В Сургут первые отряды студентов спали прибывать летом 1965 года. Самым многочисленным из них был отряд «Верховина» из Львова (65).

В 1966 году по просьбе Тюменского обкома КПСС в Сургут было направлено 2150 молодых людей трудиться на строительных объектах города и района. Они представляли более $1 / 3$ всего строительного отряда студентов, дислоцированного в Тюменской области (66). В последующие годы их число увеличивалось. В 1971 году в гражданском и промышленном строительстве города и района трудилось около 2500 молодых людей из разных областей страны. Большая часть из них работала на объектах треста «Сургутгазстрой», СМУ-4, СУ-16,СУ-22, СМП-33О, строительных участках ГРЭС. В 1970-е гг. более половины состава Всесоюзного студенческого отряда работали на объектах Западно-Сибирского нефтегазового комплекса (67).

Столь активное участие молодежи, не имеющей специальной подготовки и осваивающей строительные профессии непосредственно в процессе интенсивной практической работы, возлагало на руководителей промышленных и хозяйственных коллективов большую ответственность за организацию строительных работ, соблюдение правил техники безопасности, обеспечение благоприятных условий отдыха, питания и медицинского обслуживания бойцов студенческих отрядов.

Руководители партийных и строительных организаций города Сургута осознавали такую ответственность. В мае 1971 года бюро Сургутского городского комитета КПСС приняло специальное Постановление «О приеме и организации работы студенческих строительных отрядов», которое было обсуждено парткомами Управления строительством ГРЭС и треста «Сургутгазстрой», а также партийными организациями СМУ-8, СМП-384, 


\section{ГОРОДСКОЕ СТРОИТЕЛЬСТВО В ХАНТЫ-МАНСИЙСКОМ АВТОНОМНОМ ОКРУГЕ - ЮГРЕ (к.1950-х - сер.1990-х г2.)}

СУ-16, СУ-14. В ходе его обсуждения совместно с хозяйственными руководителями этих подразделений были приняты планы конкретных мероприятий, ставшие руководящими документами производственной и общественно-политической работы по организации труда и быта прибывающих в Среднее Приобье бойцов студенческих строительных отрядов (68).

Такая работа, начиная с 1966 года, систематически осуществлялась на основе соответствующих постановлений Сургутского городского комитета КПСС строго под контролем его промышленно-транспортного отдела. В целях еще большего усиления внимания к деятельности студентов во время трудового семестра за отдельными отрядами закреплялись ответственные работники горкома ВЛКСМ и строительных организаций. Для размещения штаба студенческих отрядов и медицинского пункта руководство «Сургутгазстроя» и ГРЭС выделяли специальные помещения.

Можно констатировать, что партийные и хозяйственные организации Сургута проводили достаточно большую работу по обеспечению прибывающих студентов строительных отрядов необходимым фронтом работ, материалами, механизмами и инструментом, созданию благоприятных условий для обеспечения их быта и отдыха. С ними проводилась достаточно большая профилактическая работа по соблюдению техники безопасности при проведении строительно-монтажных работ.

Однако первоначально возникшее движение студенческих строительных отрядов как инициатива отдельных вузов, став под эгидой ЦК КПСС массовым во второй половине 1960-х гг., выдвигало перед региональными строительными организациями трудноразрешимые производственные и социальные задачи. Не случайно то, что руководители ряда строительных организаций города Сургута в ряде случаев по объективным причинам оказывались недостаточно подготовленными к приему такого большого количества студентов, не в состоянии были обеспечить их необходимым фронтом работ, плохо организовывали их быт, не создавали в полной мере безопасных условий работы на строительных объектах.

Особенно очевидно это проявлялось на начальном этапе включения студенческих отрядов в строительное производство. В 1966 году руководство СМУ-9 не сумело своевременно обеспечить прибывшие студенческие бригады Львовского политехнического института фронтом работ, что привело к их простою в течение пяти дней. СУ-10 в начале трудового семестра того же года смогло расставить на строительные объекты Сургута только 80 человек из 205 прибывших минских студентов. СМУ-4 не сумело подготовиться к приему 
студентов Киевского инженерно-строительного института, в результате чего отряд был передан другой строительной организации. В СУ-16 бойцы студенческого отряда Тюменского индустриального института испытывали большие трудности в ходе использования строительных механизмов, которые не были своевременно отремонтированы техническими службами управления (69).

Летом 1967 года была неудовлетворительно организована работа студентов в СУ-8 треста «Сургутгазстрой», где 80 человек из Днепропетровского студенческого отряда на строительстве базы стройиндустрии не были полностью обеспечены работой в течение нескольких дней из-за отсутствия строительных материалов, а значительная часть строительных работ выполнялась вручную. В этой строительной организации из-за необеспеченности строящихся объектов стройматериалами, электроэнергией, необходимым рабочим оборудованием студенты до конца июля не были включены в работу по отделке школы на 964 учащихся, строительству клуба на 329 мест и других социальных объектов.

Имелись серьезные упущения в руководстве трестами расстановкой студентов по строительным объектам. В 1967 году в Сургуте больше половины студентов были расставлены на строительстве производственных объектов, хотя обязательства по вводу в строй юбилейных культурно-бытовых объектов строительными управлениями не выполнялись. Руководители студенческих отрядов высказывали существенные замечания по обеспечению строящихся объектов проектно-сметной документацией, работе транспорта по доставке бойцов на возводимые объекты (70).

Следует признать, однако, что по мере накопления опыта организационной работы по приему студенческих строительных отрядов таких просчетов в деятельности хозяйственных руководителей становилось заметно меньше. С другой стороны, руководители самих студенческих отрядов выработали формы контроля за этой работой. Теперь студенты заблаговременно, за несколько дней перед выездом основного контингента бойцов, высылали своих представителей на объекты дислокации и работы строительного отряда для проверки готовности хозяйственных организаций к его приему. Такие десанты «квартирьеров» оказались очень эффективными. Однако и в дальнейшем факты неудовлетворительной организации деятельности студенческих отрядов имели место. Например, в 1972 году студентам пришлось работать на строительных участках СУ-8, СУ-28 и ГРЭС с 
неисправными механизмами, нарушая правила техники безопасности и охраны труда (71).

Бойцы студенческих строительных отрядов, работавшие в Управлении строительством ГРЭС, не были обеспечены качественной питьевой водой, в СУ-9 - кухонной посудой, в СМУ-8 - постельными принадлежностями. Лагеря строительных отрядов в СУ-8 и СУ-28 треста «Сургутгазстрой» не были укомплектованы средствами пожаротушения и находились в пожароопасном состоянии (72).

Это происходило в условиях, когда интенсивность работы бойцов студенческих отрядов, дислоцированных в Тюменской области, была очень высокой. Здесь выработка на одного работника студенческого отряда составляла в 1969 году 5117 рублей, в то время как в строительных отрядах Томской области в том же году была почти в два раза ниже и составляла 2666 рублей (73).

В такой ситуации энтузиазм молодых строителей с их стремлением к многократному увеличению норм и объемов выполняемых работ часто сопровождался грубейшими нарушениями правил эксплуатации строительных механизмов и технологии производства, техники безопасности при организации строительных работ, приводил к производственному травматизму и несчастным случаям, имевшим порой смертельный исход. В результате грубейших нарушений организации производства и охраны труда в 1969 году погиб студент Львовского политехнического института П.П. Саик (74). 15 июля 1972 года, в 9 часов утра, при разборке лесов на строительстве пристройки к бетонному заводу Управления строительством ГРЭС произошел обвал строительных конструкций, под завалом которых погиб студент Бережанского техникума механизации и электрификации сельского хозяйства И.Т. Кацан (75).

Реальная производственная и бытовая повседневность общества «развитого социализма» открывала студентам, будущим руководителям трудовых коллективов, реальные, a не мнимые проблемы «его совершенствования». Уроки передовых методов управления и технологии строительных работ наряду с фактами вопиющей бесхозяйственности и неэффективности командно-административной системы, беспощадных форм эксплуатации энтузиазма передовых рабочих станут бесценным опытом для их дальнейшей трудовой деятельности. Многие активисты студенческих отрядов 1960-1970-х гг. навсегда свяжут свою судьбу с Ханты-Мансийским автономным округом и Тюменской областью. Из их числа выйдет целый ряд крупных руководителей строительства: В. Игольников, В. Потапов, 
П. Нидзельский, В. Возняк. Добрую память оставили о себе на сибирской земле Анатолий Мандриченко, Геннадий Широков, Виталий Сокол, Владимир Михайленко (76).

Прибывший в 1966 году в Сургут в составе студенческого отряда Львовского политехнического института Л.Ю. Рокецкий проявил себя как талантливый организатор работы студентов на строительных объектах города и района. После окончания института и вручения диплома о высшем образовании он был приглашен на работу в систему Миннефтегазстроя, где прошел путь от мастера до главного инженера треста «Сургутгазстрой». С 1982 года по апрель 1990 г. Л.Ю. Рокецкий работал в качестве заместителя председателя Сургутского горисполкома по строительству и председателем горисполкома.

В апреле 1990 года Л.Ю. Рокецкий был избран председателем Тюменского облисполкома, депутатом Тюменского областного совета, членом обкома КПСС. В августе 1991 года он поддержал Бориса Ельцина, в ноябре стал первым заместителем главы администрации Тюменской области. С января 1993 года - главой администрации Тюменской области. С 12 января 1997 года по январь 2001 года являлся губернатором Тюменской области, а с 8 июня 2001 года по февраль 2007 года работал представителем Таймырской (ДолганоНенецкой) окружной Думы в Совете Федерации (77).

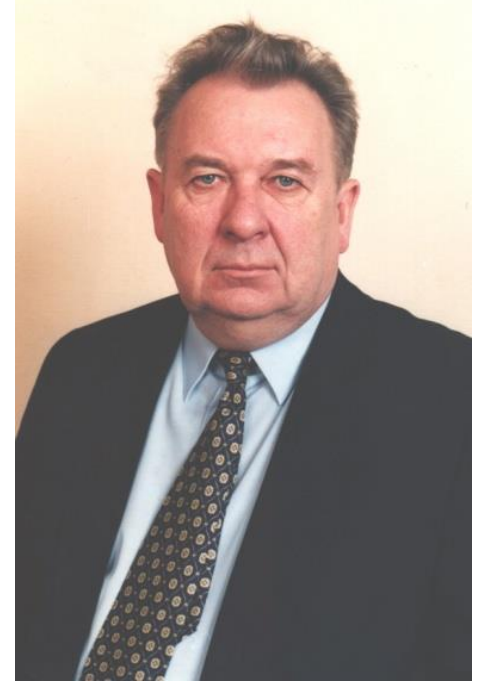

Леонид Юлианович Рокецкий, главный инженер и управляющий трестом «Сургутгазстроя» (1977-1980), заместитель председателя (1980-1988), председатель (1988-1990) Сургутского горисполкома, глава администрации и губернатор Тюменской области (1993-2001), сенатор (2001-2005) 
Как мы отмечали, большой вклад в градостроение Сургута внес директор ЛенЗНИИЭПа Семен Владимирович Билецкий, бывший боец студенческого строительного отряда, дислоцированного в Сургуте (78).

Вузовские студенческие строительные отряды сыграли большую роль в градостроении округа. В 1968 году они участвовали в строительстве шести 12-квартирных домов, осуществляли работы по нулевым циклам 80квартирных домов в поселке нефтяников Сургута. Совместно с СУ-22 выполняли большой объем работ по благоустройству и послеосадочному ремонту домов в поселках геологов, нефтяников и строителей. Всего в 1971 году студентами было освоено 6881 тыс. рублей капитальных вложений. Из них в ходе жилищного строительства - 1659 тыс. рублей, на объектах соцкультбыта - 650 тыс. рублей и в промышленном строительстве - 4552 тыс. рублей. В течение трудового семестра в 1971 году на стройках Сургута и Сургутского района ими было сдано в эксплуатацию 7 различных объектов и подготовлено к сдаче 12. Студенческие строительные отряды участвовали в строительстве 4 школ, 6 детских садов, выполнили работы по благоустройству и построили детский парк в микрорайоне энергетиков, вырубили более 40 километров просеки на строительстве железной дороги Тюмень-Нижневартовск, уложили 12,2 км инженерных сетей и коммуникаций, оказали практическую помощь в ремонте школ и детских учреждений, в своевременном проведении сельскохозяйственных работ (79).

Особую трудовую и общественно-политическую активность проявили в тот год бойцы Львовского объединенного студенческого отряда «Верховина», занявшего первое место среди студенческих отрядов Украины по Тюменской области. Командир отряда Зиновин и комиссар Костенко были награждены Почетной грамотой Сургутского горкома КПСС, исполкомов городского и районного Советов депутатов трудящихся (80).

В 1972 году объем освоенных капитальных вложений настройках округа значительно возрос. Только в Сургуте и Сургутском районе в летний период он был увеличен студентами на 419 тыс. рублей и составил уже 7 млн. 300 тысяч рублей. Они построили 4 и подготовили к сдаче 12 объектов. Будущие специалисты высшей квалификации приняли участие в строительстве 3 детских садов, 2 школ, 2 детских парков и ремонте других многочисленных важных социальных объектов. Кроме этого, студенты выполнили большой объем работ при сооружении железнодорожной насыпи Тюмень-Сургут и возведении Сургутской ГРЭС (81). 
После нескольких лет работы молодые строители оставили сургутянам улицы жилых домов, которым сами и дали названия: Артема, Марии Поливановой, Восход, Московская, Энтузиастов (82).

Очень важно при этом отметить, что студенты брали на себя и решение вопросов культурно-просветительской работы с жителями округа. Только в течение двух месяцев лета 1971 года ими было прочитано 187 лекций, дано 57 концертов, организовано 28 вечеров отдыха молодежи, налажена работа пионерского лагеря в поселке Белый Яр, где отдохнуло 80 учащихся. Студенты медицинских вузов оказывали помощь лечебно-профилактическим учреждениям региона (83). Сегодня ветераны Сургута с теплотой вспоминают о работе студенческой мастерской бытовой техники «Спасибо», где по вечерам будущие инженеры бесплатно ремонтировали престарелым жителям города утюги, примусы, керосинки, патефоны и другую домашнюю утварь (84).

Заметный след в истории городского строительства в ХМАО-Югре оставили и специалисты из Народной Республики Болгария. Идея создания болгарской строительной группы возникла в середине 1970-х гг. в рамках экономических соглашений между Советским Союзом и Народной Республикой Болгария. К этому времени болгарские строители уже не первый год успешно работали на объектах Курской магнитной аномалии, лесодобычи в Коми АССР, где было создано несколько болгарских поселков. Они работали на возведении Архангельского целлюлозно-бумажного комбината. После его успешного завершения летом 1976 года отряд квалифицированных болгарских специалистов перебросили на гражданское и жилищное строительство в областной центр и ряд городов округа (85).

В том году на сессии городского Совета депутатов управляющий трестом «Сургутгазстрой» говорил: «В тресте налицо проблема увеличения рабочих на 1000 человек. Половину мы решаем за счет болгарских товарищей... В сентябре мы ожидаем прибытия трехсот человек и далее еще двухсот» (86). Первоначально они были задействованы на строительстве социальнокультурных объектов, возводимых «Сургутгазстроем», и монтаже «хрущевских» пятиэтажек. Однако память о себе болгарские строители оставили главным образом возведением ярких для тех времен архитектурных стандартов домов на проспекте Набережном, напротив бывшего завода арбоблоков «Арболит». Эти восьмиэтажные здания, с некоторыми изменениями летнего варианта первоначального проекта, долгое время 
считались гордостью Сургута. В одном из них была размещена самая комфортабельная в те времена в городе гостиница «Обь».

Болгарская строительная группа, насчитывавшая в 1980-е гг. около 3 тысяч строителей (87), активно принимала участие и в изготовлении комплектующих строительных конструкций. Основным их поставщиком в Сургуте был завод железобетонных изделий сургутского ДСК. В 1978 году из-за допущенного работавшими там заключенными местных исправительных учреждений брака произошло обрушение одного из готовых к сдаче строительных объектов, расположенных на «Арболите». Комиссия, расследовавшая причины обрушения, приняла решение о разборке нескольких уже возведенных домов и отстранении от работы на ЖБИ полуторатысячного «спецконтингента» заключенных. Операция замены заключенных была проведена молниеносно, и об этом не знали даже руководители исправительных учреждений. К минимуму были сведены размеры сознательной порчи оборудования, которую могли сделать заключенные, хотя без диверсии с их стороны все-таки не обошлось. Они срочно были заменены болгарскими рабочими, сумевшими без заметного перерыва обеспечить сохранение темпов и объемов производства промышленной продукции завода железобетонных изделий Сургутского ДСК (88).

Совместное советско-болгарское сотрудничество в градостроении Сургута продолжалось до января 1991 года. После известных политических изменений в странах Восточной Европы конца 1980-х-начала 1990-х гг. Советский Союз разорвал соглашение, и около 48000 болгарских строителей покинули страну. Кроме Сургута, болгарские строители трудились на многочисленных объектах Тюмени, Нефтеюганска, Нижневартовска, Урала, Нового Уренгоя и Надыма. В Сургуте, в соответствии со специальным Постановлением Правительства России, осталось проживать около 440 человек болгар, членов образованных за годы их пребывания в Сургуте интернациональных семей (89).

Благодаря самоотверженному труду всех участников городского строительства в Сургуте, обеспечение его населения качественным жильем заметно росло. Несмотря на повсеместный «строительный обвал» в эти годы, Сургут возводил две трети жилищного фонда всего Ханты-Мансийского автономного округа (90).

На фоне интенсивно развивающихся новых нефтяных городов обращает на себя внимание особенность градостроения в столице округа - Ханты- 
Мансийске. Оказавшись за пределами эпицентра судьбоносных геологических открытий, город не имел градостроительных предприятий и поэтому неизмеримо уступал по темпам жилищного строительства и благоустройству новым «провинциальным» городам. Численность населения Ханты-Мансийска в 1970-1980-е гг. практически не росла. В 1971 году она составляла 24,8 тыс. человек, а в 1980 году - 28,1 тыс. человек (92). Он продолжал сохранять первозданные черты района Самарова, построенного еще в 1930-1940-е гг. Ханты-Мансийск состоял преимущественно из двухэтажных деревянных домов, из которых только половина была оборудована частичными коммунальными удобствами, включающими центральное отопление, водопровод и канализацию. Районы частной застройки вообще их не имели. В городе сохранялись многочисленные и многоквартирные бараки-общежития, построенные ещё в первые годы основания Остяко-Вогульска.

В июле 1930 года была создана специальная комиссия, в задачи которой входил выбор места для строительства окружного центра. Проекты расположения окружного центра в Октябрьском и Сургуте отпали, так как первый был слишком удален от сургутских и кондинских ханты манси, а второй от березовских и кондинских. Площадка на берегу Оби, у устья Иртыша, оказалась сильно изрезанной глубокими оврагами - отпал и этот вариант. Тогда комиссия избрала местом строительства глубокое урочище Большой Черемушник, расположенное в 5 км к северу от Самарово, за Самаровой горой.

Здесь стояла вековая сибирская тайга, могучий кедровник. В декабре 1930 года в тайге были прорублены просеки, обозначавшие улицы и кварталы. Всего планировалось построить улиц длиною в 15 км. В мае 1931 года в тайгу вышли бригады строителей. Первым зданием, построенным в окружном центре, был Дом Туземца. Сразу же за ним были заложены Дом Советов, здание окружного отдела милиции и семь жилых домов.

В 1935 году в окружном центре развернулось дорожное строительство. Был получен трактор, который использовался на раскорчёвке дороги, соединяющей Остяко-Вогульск с Самарово. В 1938 году дорога была вымощена булыжником. В 1937-1941-е гг. в поселке вступили в строй новая электростанция, однорамный лесопильный завод, а в южной части Самаровомеханические мастерские. Авиалиния Тюмень - Тобольск - Самарово Березово - Салехард связывала окружной центр с другими городами (93). 
В ходе разведки тюменской нефти Ханты-Мансийск становился одной из баз продвижения нефтяников и газовиков в центр Западной Сибири. В городе обосновался Геофизический трест и объединение «Хантымансийскнефтегазгеология».

В конце 1960-х - начале 1970-х гг. начинает осуществляться более активное благоустройство города. Появляются кирпичные дома, создаётся предприятие объединённых котельных и теплосетей, городское ремонтностроительное управление, была протянута ЛЭП от Сургутской ГРЭС для надежного электроснабжения города, начата прокладка городского водопровода, был построен собственный асфальтовый завод. В 1967 году начали работу телецентр и окружная студия телевидения. В 1977 году сданы в эксплуатацию Дворец культуры «Октябрь» на 600 мест и новая средняя школа на 964 учащихся. Построены первая пятиэтажка из сборного железобетона, здание Госбанка, торговый центр. В институте Ленгипрогор по инициативе первого секретаря горкома КПСС В.И. Рыбкина приступили к выполнению заказа на составление генерального плана развития города с домами повышенной этажности.

Следует заметить, что современный образ Ханты-Мансийска начал особенно интенсивно приобретать свои черты после 1993 года, когда округ обрел статус субъекта Российской Федерации и получил возможность формировать собственный бюджет. 28 марта 1995 года окружная Дума приняла закон о статусе города Ханты-Мансийска как столицы субъекта Российской Федерации, что еще более укрепило его административный и социальный престиж.

В последующие годы город, как центр крупнейшего российского нефтегазоносного региона, приобретает новое качественное развитие, не последнюю роль в котором сыграл губернатор округа А.В. Филипенко. Его численность населения увеличилась более чем втрое. Были построены новые современные, полностью благоустроенные жилые кварталы кирпичных и бетонных домов, широкие дороги с удобными развязками. В городе появилось множество современных медицинских учреждений и разнопрофильных спортивных центров как для взрослых, так и для детей, формировалась богатая культурная жизнь, включавшая разнообразные образовательные возможности, в том числе и поступления в Югорский государственный университет (94).

У Ханты-Мансийска есть оригинальное лицо: город утопает в зелени, окружен лесами и извилистой лентой Иртыша, имеет своеобразную 
архитектуру. Следует согласиться с мнением авторитетных градостроителей России о том, что «у маленького города Ханты-Мансийская - большая история и большие перспективы» (95).

Возвращаясь к предмету нашего исследования, вновь обращаемся к таблице № 13, свидетельствующей на примере Сургута о том, что ежегодный ввод жилья полезной площади за счет всех источников финансирования в округе интенсивно рос. Если в 1971 году - первом году ввода в эксплуатацию Сургутского домостроительного комбината - в городе было построено 27 зданий, в том числе 26 домов в крупнопанельном исполнении, с общей полезной жилой площадью 103,8 тыс. кв.м., то в 1985 году - 118 домов, 85 зданий с общей площадью 454,6 тыс. кв.м. (96) За этот период население Сургута возросло с 34000 чел. в 1970 году до 203300 чел. в 1985 году (97). Арифметический подсчет свидетельствует, что темп ввода жилой полезной площади, несмотря на высокий уровень миграции в город, существенно опережал прирост населения и выразился в коэффициентах роста 15,5 и 5,9 раза.

Характерным являлось и то, что ввод жилой полезной площади в городе Сургуте нарастал стремительными темпами. Согласно таблице № 13, если в 1971-1975 гг. он увеличился со 103,8 тыс. кв.м до 143 тыс. кв.м, то в 1976-1981 гг. - с 194,3 тыс. кв.м. до 419 тыс. кв.м. Расчет показывает, что в первом периоде прирост составил $39 \%$, а во втором $120 \%$. При таком темпе увеличения ежегодных объемов жилой площади обеспеченность ею жителей Сургута последовательно возрастала. В среднем на одного сургутянина приходилось в 1975 году 8 кв.м. жилой площади, в 1985 году - 10,9 кв.м., в 1990 году этот показатель составил уже 13,4 кв.м., в 2000 году. - 17,8 кв.м., в 2003 году - 18,5 кв.м., в 2004 году - 19,7 кв.м., в 2005 году - 19,7 кв.м., 2006 году 20,4 кв.м., в 2007 году - 20,7 кв.м., в 2008 году - 20,7 кв.м. (98).

Стремительный рост объемов жилищного строительства в Сургуте позволял его индустрии производить в 2003 году, по мнению городской газеты «Новый город», 2/3 жилой площади Ханты-Мансийского автономного округа - Югры (99), что создавало гораздо более благоприятную демографическую ситуацию по сравнению с другими городами округа. В чем не последнюю роль играл, впрочем, и не менее стремительно совершенствовашийся проектно-архитектурный ансамбль города и его социокультурное пространство. 
На фоне урбанизационных процессов в городах округа концентрация населения в Сургуте выглядела предпочтительней. Если в Нефтеюганске в 1990 году, по сравнению с 1989 годом, население возросло с 72,2 тыс. чел. до 77,5 тыс. чел., в Нижневартовске - со 177,9 тыс. чел. до 189 тыс. чел., Ханты-Мансийске - с 30,8 тыс. чел. до 31,4 тыс. чел., в Урае - с 29, тыс. чел. до 31,6 тыс. чел., в Сургуте оно увеличилось гораздо больше - со 187,8 тыс. чел. до 203,3 тыс. чел. (100.)

Не менее убедительно это выглядело и в последующие годы. В 1990-1995 гг., когда в условиях экономических и политических трудностей, переживаемых страной и округом, численность населения городов ХМАОЮгры сокращалась: Нижневартовска - с 249,3 тыс. чел. до 239,4 тыс. чел., Урая - с 39,7 тыс. чел. до 38,3 тыс. чел., Лангепаса - с 41 тыс. чел. до 36 тыс. чел (101), население Сургута незначительно, но стабильно росло. Если в 1990 году в Сургуте проживало 256,7 тыс. чел, то в 1995 г.- 263,0 тыс. чел. (102). Прирост населения составил 6300 чел.- 2,4\%.

Однако, несмотря на эту положительную тенденцию, в исследуемый период в Сургуте проблема дефицита благоустроенных квартир оставалась весьма острой. В конце 2000 года в списке очередников на улучшение жилищных условий при городской администрации состояло более 4800 семей. В 2001 году в городе насчитывалось 30 домов, называемых «фенольными», проживание в которых было признано невозможным (103). В 2005 году в Сургуте насчитывалось примерно 2000 ветхих строений, в которых проживало 5800 семей, насчитывавших 17000 человек. Их отселение велось на основе программы «Улучшение условий лиц, проживающих в ветхом жилье на территории ХМАО в 2000-2009 годы» и могло быть намного менее успешным, если бы не крупномасштабная работа по возведению объектов жилищного строительства, проделанная в округе во второй половине XX века.

К 2008 году в жилищном фонде Сургута, насчитывавшем 5765 кв.м., ветхое жилье составляло 91,2 кв.м., т.е. $2 \%$ его общего объема. Жилая площадь сборно-щитовых домов включала 72,2 кв.м., т.е. 1\%. Жилая площадь деревянных домов насчитывала 125,6 кв.м., т.е., 2.\%\%, кирпичных домов 773,7 кв.м - 13\%. Основную часть жилой площади представляло крупнопанельное домостроение, включавшее 4713 кв.м. и составлявшее $82 \%$ городского жилищного фонда (104).

Согласно данным Росстата, в ХМАО-Югре общая площадь жилых помещений городского округа по состоянию на 2013 год составила 
6996,9 тыс.кв.м., и при этом средняя жилищная обеспеченность находилась на уровне 21,1 кв.м. на человека (105).

Таким образом, городское строительство в Ханты-Мансийском автономном округе имело ярко выраженный интенсивный характер. За короткое время на территории округа обрели жизнь 15 новых городов. Их строительство было сопряжено с большими трудностями, связанными с отсутствием на начальном этапе необходимого проектно-изыскательного обеспечения, строительных нормативов и стандартов, транспортной инфраструктуры и бездорожьем, недостатками в поставках строительных материалов и механизмов. Повседневная жизнь строителей была сопряжена с суровым климатом и бытовой неустроенностью

Существенной проблемой формирования единой политики застройки нефтяных городов являлся местнический принцип организация городского строительства, его ведомственный характер. На протяжении всего периода городского строительства ХМАО-Югры для его новых городских поселений оставался актуальным вопрос единого генерального заказчика их проектирования и строительства. Возможность проведения единой централизованной политики блокировалась отсутствием службы единого генерального подряда и органов архстройконтроля, а также дисперсный характер организации проектирования селитебных и промышленных зон городов. Это приводило к хроническому однообразию повторения проблем строительства новых городов ХМАО-Югры, когда дефицит жилья сопровождался острой потребностью в социально-культурных и бытовых объектах урбанизирующегося округа.

Тем не менее в исследуемый период руководству страны, ХМАО-Югры и градообразующих предприятий удалось в целом значительно улучшить условия жизни населения округа, вводя в строй жилищные площади, темпы роста которых значительно опережали прирост городских жителей, создавая тем самым благоприятные условия расселения трудовых ресурсов новой, крупнейшей в стране энергетической провинции.

\section{Примечания}

1. ГАТО. Ф. 1861. ОП. 1. Д. 1. Л.6.

2. ГАС11ИТО. Ф.113. Оп.31. Д.7. Л.79.

3. Там же.

4. Там же. Л.110. 
5. АОАГС. Ф.80. Оп.1. Д.129. Л.7.

6. ГАСПИТО. Ф.113. ОП.31. Д.7. Л.110..

7. Таблица составлена по материалам: АОАГС. Ф.80. Оп.1.Д.129.Л.7

8. ГАСПИТО.Ф.113.Оп.31.Д.7.Л.110

9. Табл. сост. по мат.: АОГС.Ф.80.Оп.1.Д.129.Л.7

10. ГАСПИТО.Ф.113. Оп.31.Д.7.Л.78

11. ГАСПИТО. - Ф.113. Оп.31. Д.7. Л.78.

12. Архивый отдел администрации города Нижневартовска.Ф.171,71 ед. xp.1991-2004 гг. arhivugra:admhmao.ru / kratkiy - spravochnik/ 3 tom)

13. ГАСПИТО. Ф.113. Оп.31. Д.7. Л.78.

14. АОАГС. Ф.80. Оп.1. Д.130. Л.6.

15. История и перспективы градостроительного освоения Севера Западной Сибири. М.: Суханово, 2004.С.313

16. Там же. С.331.

17. Архивный отдел администрации города Нижневартовска. Ф.3/68, о.а.ф. 1025 ед.хр. 1965-1999.

18. Архивный отдел Администрации города Нижневартовска. Ф.18-16о-п, 620 ед.хр. 1971-2002.

19. Архивный отдел администрации города Нижневартовска. Ф.25/129л.212.ед.хр. 1986-1998.

20. ГАТО. Ф.1861. On.1. Д.1. Л.6.

21. Особенности градостроительства в нефтедобывающих районах Тюменской области. - Ленинград, 1972. С. 40.

22. Там же. С.30.

23. Город Сургут в цифрах. (Юбилейный статистический сборник). Сургут, 1995. С. 35.

24. ГАСПИТО. Ф.113. Оп.23. Д.6. Л.136.

25. ГАТО. Ф.1861. On.1. Д.11. Л.10.

26. Там же. Л.11.

27. Долгая дорога к нефти. Сургут, 1997. С.63.

28. Таблица сост. по материалам: ГАТО. Ф.1861. Оп.1. Д.11.Л.29.

29. Архивный отдел администрации города Нижневартовска. Ф.18/115-л. 41 ед.хр. (1988-1997).

30. АОАГС. Ф.80. Оп.1. Д.129. Л.70.

31. ГАСПИТО.Ф.113.Оп.31.Д.7.Л.77. 
32. Табл. сост. по материалам: АОАГС.Ф.80.Оп.1.Д.60.Д.3.Л.7;Ф.80. Оп.1.Д.52. Л.9; Ф.80.Оп.1.Д.58. Л.12; Ф. 80. Оп.1. Д.76. Л.21; Ф.80.Оп.1.Д.68. Л.31;Ф.80.Оп.1.Д.91.Л.2;Ф.80.Оп.1.Д.80.Л.6;Ф.80.Оп.1.Д.114.Л.14;Ф.80.Оп.1. Д.125. Л.9.

33. ГАСПИТО.Ф.113.ОП.24.Д.3.Л.99.

34. ГАСПИТО.Ф.113. Оп.19.Д.39.Л.39 об.

35. Дворникова Т. Здесь будет город сад? // МК Югра. 2002. 21-22 февраля.

36. ГАСПИТО. Ф.113.Оп.31.Д.7.Л.103

37. ГАСПИТО.Ф.124.Оп.191.Д.73.Л.47.

38. Западно-Сибирский нефтегазовый комплекс. История становления. Ч.2. Тюмень, 2005. С.64.

39. ГАСПИТО.Ф.124. Оп.191.Ф.73.Л.47.

40. ГАСПИТО.Ф.124. Оп.191.Д.4.Л.75.

41. ГАТО.Ф.1861.Оп.1.Д.228.Л.15-16.

42. Григорий Северный. Улица иронии судьбы. // Элетронная трибуна. 2007. 23 марта

43. История и перспективы... С.183.

44. Там же.

45. ГАТО. Ф.1861. Оп.1. Д.22. Л.15.

46. Там же.

47. Мунарев П.А. Указ.соч.С.71.

48. ГАСПИТО.Ф.113. Оп.23.Д.6.Л.136.

49. Там же. Л.11.

50. Там же.

51. Там же.

52. Там же.

53. Баталин Ю.П.Указ. соч. С.33.

54. Григорий Северный. Указ.соч.

55. Из воспоминаний В.Г. Чирского // История и перспективы... С.183.

56. ГАСПИТО. Ф.107. Оп.1. Д.2204. Л.37.

57. Из воспоминаний В.Г. Чирского...С.183.

58. Там же.

59. ГАСПИТО. Ф.107. Оп.1. Д.224. Л.37.

60. Гаврилова Н.Ю.Социальное развитие нефтедобывающих районов Западной Сибири. (1964-1985 гг.). Тюмень, 2002. С.43. 
61. Сургутская трибуна. 1990. 6 октября

62. Город Сургут в цифрах. (Юбилейный сборник). Сургут, 1995. С.118.

63. ГАСПИТО. Ф.113. ОП.29.Д.32.Л.5.

64. Там же. Л.7.

65. ГАСПИТО. Ф.124. Д.131. Л.40

66. Новый город.2004. 18 февраля.

67. ГАСПИТО. Ф.113.Оп.19.Д.7.Л.9

68. Баталин Ю.П. Вместо предисловия. // История и перспективы градостроительного освоения. С.33.

69. ГАСПИТО. Ф.113. Оп.23. Д.17. Л.112.

70. ГАСПИТО. Ф.113. Оп.19. Д.7. Л.8.

71. ГАСПИТО. Ф.113. Оп.19. Д.43. Л.15.

72. ГАСПИТО. Ф.113. Оп.24. Д.4. Л.15.

73. Там же.

74. ГАТО. Ф.1861. Оп.1. Д.484. Л.158

75. ГАСПИТО.Ф.113.Оп.21.Д.6.Л.34

76. ГАСПИТО.Ф.113.Оп.24.Д.4.Л.17

77. Шмаль Г.И. Юность комсомольская моя.// Соратники. Поколение Виктора Муравленко. Тюмень, 2002. С.377-378

78. Режим доступа: wiki 2.org Рокецкий Леонид Юлианович.

79. Новый город.2004.18 февраля

80. ГАСПИТО.Ф.113.Оп.23.Д.17.Л.113.

81. Там же.

82. ГАСПИТО.Ф.113.Оп.24.Д.4.Л.210

83. Новый город.2004.18 февраля.

84. ГАСПИТО.Ф.113.Д.17. Л.113.

85. Новый город. 2004. 18февраля.

86. Введенский В.В.Как болгары Сибирь покоряли // Югра. 2004. № 7. C.29.

87. АОАГС.Ф.3.Оп.1.Ф.101.Л.225.

88. Введенский А. Как болгары Сибирь покоряли. // Югра. 2001. №7. С.29

89. Там же.

90. Там же.

91. Новый город.2003.9 августа.

92. Стась И.Н. Стать горожанином: урбанизация и население в нефтяном крае. (1960-е-нач.1990-х гг.). Курган, 2018.С.42. 
93. Режим доступа: vhanty mansiysk. ru /history/ hm tml

94. Режим доступа: admhmansy.ru / city/ history. php

95. Режим доступа: wikiway. com / russia / khanty-mansiysk

96. Табл. сост. по материалам: АОАГС.Ф.80.Оп.1.Д.60.Д.3,Л.9;Ф.80. Оп.1.Д.52. Л.7; Ф.80.Оп.1.Д.58. Л.12; Ф. 80. Оп.1. Д.76. Л.21; Ф.80.Оп.1.Д.68. Л.31;Ф.80.Оп.1.Д.91.Л.2;Ф.80.Оп.1.Д.80.Л.6;Ф.80.Оп.1.Д.114.Л.14;Ф.80. Оп.1. Д.125. Л.9.

97. Город Сургут в цифрах. (Юбилейный статистический сборник). Сургут, 1995. С. 35.

98. Режим доступа: docvic wer yandex.ru /wier/ 40075351112/ ? page

99. Новый город.2003.9 августа.

100. Стась И.Н. Стать горожанином: урбанизация и население в нефтяном крае (1960-е-начало 1990- х гг.). Курган, 2018.С.42

101 Он же. Кризис организации и системы городского расселения Ханты-Мансийского автономного округа в первой половине 1990-х гг. // Вестник Югорского государственного университета. 2013. Вып.1. С.59.

102. Город Сургут в цифрах. (Юбилейный статистический сборник). Сургут, 1995. С. 35.

103. Югра.2001. № 12. С.8.

104. Югра.2001. № 12. С. 8.

105. Режим доступа: docvic wer yandex.ru /wier/ 40075351112/ ? page 


\section{ГЛАВА 6. \\ БЛАГОУСТРОЙСТВО НОВЫХ СЕВЕРНЫХ ГОРОДОВ}

Градостроительная стратегия в Западной Сибири, сильно зависимая от природно-климатических, географических условий и фактора времени, поновому определяла и последовательность решения ее основных задач.

По воспоминаниям первого главного инженера строительного главка «Главтюменнефтегазстроя», созданного в 1965 году для обустройства крупнейшей в стране нефтегазовой провинции, Ю.П. Баталина, «поначалу ситуация была тупиковой». Самой трудной проблемой тогда являлось отсутствие дорог на заболоченных территориях. В Азербайджане практически круглый год можно было проехать к любой точке нефтедобычи. В Татарии и Башкирии на строительство проездных путей была брошена дивизия военных строителей, и этого оказалось достаточно. Она успешно справилась с поставленной задачей и в опережающем режиме сделала автомобильные дороги. «А как быть в Сибири, где ни дорог, ни тверди под ногами и почти сплошь болота и вода?» - задавал он далеко не теоретический вопрос (1).

Очевидцы вспоминали, что в Сургуте в 1960-е гг. топкую яму, длительное время стоявшую перед строениями поселка нефтяников, не могли преодолеть даже автомобили-вездеходы. Машины через нее перетаскивал специально предназначенный для этого гусеничный трактор С-100. Во время дождей дороги становились непреодолимыми. Улицы города размывались до основания, по ним невозможно было пройти даже в яловых сапогах. В ненастные годы хлеб в магазины завозили на гусеничном вездеходе. На таком же вездеходе работали врачи «скорой помощи». Резкий наплыв строительной техники в города приводил дороги в катастрофическое состояние. В середине 1960-х гг. пассажирские автобусы не могли проехать до таких жизненно важных центров Сургута, как Районный тубдиспансер и «Сургутнефть». В 1968 году в городе сложилась критическая ситуация из-за обрыва транспортной связи с аэропортом (2).

Ханты-Мансийская транспортная контора и Тюменское автоуправление, на которые были возложены задачи обустройства эксплуатируемых магистралей, не располагали достаточным количеством дорожно-строительных механизмов и были не в состоянии с ними справиться. Единственный грейдер, имевшийся в наличии Сургутской нефтеразведочной экспедиции, большую 
часть времени был задействован на выполнении непосредственных геологоразведочных работ (4).

Трудности создания городской транспортной инфраструктуры в новых административных центрах усугубляли многочисленные ручьи и притоки Оби, рассекающие их на части. В Сургуте серьезной проблемой являлось преодоление речки Саймы, разделявшей строящийся город на два центра, Старый Сургут и Черный Мыс. Беспокойство вызывал построенный еще в 1952 году ряжевый мост через Сайму, соединявший Старый Сургут с Черным Мысом, где располагались речной порт, аэропорт, рыбконсервзавод и другие жизненно важные для города предприятия и учреждения.

Его строительство имело давнюю историю. Еще в 1961 году исполком Сургутского районного Совета депутатов трудящихся решил в соответствии с Указом Президиума Верховного Совета РСФСР от 7 апреля 1957 года начать строительство автомобильного моста, связывающего западную часть рабочего поселка Сургут с восточной, сургутскую экспедицию, рыбокомбинат, райсоюз, леспромхоз и ОРС, райконтору связи, промкомбинат и электростанцию. Руководителей этих предприятий исполком обязал до 1 ноября 1961 года обеспечить строительство моста стройматериалами и рабочей силой (5).

Однако, по воспоминаниям П.А. Мунарева, осуществить эту «всенародную стройку» не спешили. Мост, рассчитанный для проезда только гужевого транспорта, благополучно простоял до открытия нефтяных месторождений. Но с началом их промышленного освоения через него пошли машины всех марок, а порой проходили даже многотонные тягачи МАЗы-357 «Ураган». «Мы боялись, - вспоминал П.А. Мунарев, - что в половодье сильные майские ветры его раскачают и унесут» (6).

C началом промышленного развития города ускоренно была заказана проектная документация на мост через Сайму. Ее подготовили, но не на мост, а на плотину с мостовым переходом. По замыслу авторов, плотина должна была создать хороший городской пруд. Поскольку уровень воды в Оби часто поднимался выше допустимого уровня в создаваемом пруду, в теле плотины, кроме водоспускных шлюзов, предусматривалась станция перекачки воды по трубам. Гидромеханизаторов в городе тогда еще не было, и построить такое сооружение никто не брался. Поэтому вторично заказали проектную документацию. Теперь уже проект был перестроен так, что мост легко было переоборудовать в плотину (7). 
Чтобы разгрузить внутренние магистрали города, была построена окружная дорога, поэтому в 1963 году райисполком запретил движение по улицам поселка автомашинам с автокранами, прицепами и другими приспособлениями, категорически рекомендуя им с апреля до ноября использовать дорогу вокруг Сургута (8).

22 февраля 1966 года бюро Тюменского областного комитета партии совместно с областным исполнительным комитетом депутатов трудящихся приняло решение о завершении строительства общегородской магистрали, проходящей через Старый Сургут от Черного Мыса до жилого района нефтяников, и приступить к строительству мостового перехода через реку Сайма (9).

В соответствии с решением бюро Тюменского областного комитета КПСС силами рыбокомбината, райсоюза, леспромхоза и ОРСа, райконторы связи, промкомбината и электростанции «народное строительство» автомобильного моста было успешно завершено, связав западную и восточную части города и осуществив «многовековую мечту» сургутян о воссоединении материковой и речной частей средневекового поселения.

В Сургуте существовал и другой мост, соединявший жилой поселок строителей со Старым Сургутом. Он в то время для горожан представлял очень большое жизненное значение, так как в нем располагались госбанк, сберкасса, Дом культуры, кинотеатр, магазины и столовая. Этот мост во время паводка и дождей часто сносило, и предприимчивые сургутские мальчишки пользовались этим, зарабатывая себе на конфеты. Была установлена такса перевоза на лодке: 20 копеек для трезвых пассажиров и рубль для подвыпивших (10).

Критика по поводу периодического разрушения этого моста звучала повсеместно. Но горисполкому из-за отсутствия финансирования и проектирования трудно было построить новый мост. После длительных разговоров в исполкоме инициативу взял на себя начальник Мехколонны № 14, впоследствии развившейся в мощный строительный трест «Запсибэлектросетьстрой», Игорь Алексеевич Киртбая. Он решил вопрос с финансированием. На воскреснике силами автобазы № 4 во главе с начальником Петром Николаевичем Кротовым, автотранспортной конторы нефтяников, возглавляемой директором Виктором Лаврентьевичем Полюшкиным, автобазы геологов, руководимой Иваном Петровичем Дмитриевым, за один день отсыпали грунт. В карьере его на общественных началах грузили механизмы УМ-3во главе с его начальником Виктором 
Александровичем Чернышевым. СУ-16 треста «Спецгазстрой» под руководством Владимира Ивановича Балаклеенко забило в качестве опор стальные трубы, сварило горизонтальны швеллеры, участок «Ремстроя» сделал деревянный настил. Пешеходный мост был готов. Позже СУ-16 построило пешеходные мосты, связывающие поселки геологов и строителей, Старый Сургут и микрорайон строителей (11).

Большое значение для обеспечения города всеми необходимыми ресурсами и обустройства нефтяных промыслов имело тогда строительство дороги, связывающей Сургут с Нефтеюганском. Оно осуществлялось на основе Постановления Совета министров СССР № 208 от 4 декабря 1963 года и Приказа Государственного производственного комитета по транспортному строительству СССР от 19 декабря 1963 года № 234. В соответствии с этими документами проектирование автомобильной дороги Сургут-Нефтеюганск было поручено Киевскому филиалу государственного проектного института «Союздорпроект». 20 августа 1964 года исполком Сургутского поселкового Совета одобрил направление трассы этой дороги, проходящей «от причала на протоке Юганская Обь по улице проектируемого поселка Нефтеюганск, по южной окраине промзоны центрального нефтесборного парка Усть-Балыкского месторождения, находящегося на урочище Сингапайских островов, и далее в восточном направлении по островам Каменному и Городскому до примыкания к трассе проектируемого «Сибгипротрансом» мостового перехода через реку Обь у города Сургута» (12).

Необходимо еще раз подчеркнуть, что вследствие ведомственного разобщения градостроительства в Сургуте единого основного заказчика на строительство дорог в городе не было. В их роли выступали такие организации, как НГДУ «Сургутнефть», УСГРЭС, трест «Сургутгазстрой», нефтеразведочная экспедиция и эпизодически некоторые другие. Основная доля приходилась на НГДУ «Сургутнефть» как объявленного генерального застройщика города. Достаточно сказать, что только в 1972-1975-х гг. из 22,5 км. построенных магистральных дорог 8 км стоимостью в 1 млн. 818 тыс. рублей ввела в эксплуатацию эта организация. К 1980 году НГДУ планировало построить 28 км дорог стоимостью 9 млн. 600 тыс. рублей (13). Вторым предприятием, активно занимающимся строительством дорог в Сургуте, была ГРЭС, которая за этот период возвела 3,1 км дорог стоимостью 697 тыс. рублей (14).

Однако инициаторами строительства дорог с твердым покрытием в Сургуте выступили геологи (15). Из-за отсутствия финансирования и 
необходимых проектов они строили дороги за счет благоустройства своего района. У них не было железобетонных плит, поэтому бетон строители треста «Сургутгазстрой» укладывали непосредственно в арматуру полотна дороги. В 1965 году исполком поселкового Совета отмечал: «Учитывая заявление начальника нефтеразведочной экспедиции т. Чебана Н.И. о плохом качестве строящейся дороги, предложить начальнику Строительного управления № 9 А.Г. Кошману проверить и улучшить качество работы на строительстве дороги, обратить особо внимание на укладку арматуры». В этом же постановлении исполком напоминал руководителям СУ-9: «Принять к сведению заявление начальника строительного управления № 9 т. Кошмана А.Г. о том, что строительство дороги с твердым покрытием протяженностью 5 км в восточной части города будет закончено к 1 ноября 1965 года» (16).

Геологи успешно справились с этой задачей и силами СУ-9, как вспоминал П.А. Мунарев, «построили дорогу по всему Черному Мысу протяженностью 4 километра» (17). Нефтяники строили дорогу от своего поселка до Старого Сургута. В июле 1964 года в Сургуте была создана дорожно-строительная контора под руководством А.М. Колесникова. Ориентированная преимущественно на обеспечение подъездных путей к местам бурения и подготовку их производственных площадок, большое внимание она уделяла и дорожному строительству внутри города. В 1965 году началось сооружение твердого покрытия на сургутских улицах силами нефтяников. Первой из них стала ведущая к нефтебазе улица Гагарина. В порядке эксперимента ее решено было залить сырой нефтью с наполнителями. Затем на улицах Республики, Просвещения и Красных партизан появилось гравийное покрытие. В связи с этим в 1966 году исполком горсовета запретил проезд гусеничного транспорта по центральной улице (18). В 1969 году была введена дорога с твердым покрытием, соединившая западную и восточную части города (19).

В последующие годы, благодаря совместным действиям городской администрации, строительных организаций и крупных предприятий «Сургутнефтегаза» и «Тюменьэнерго», городская улично-дорожная сеть становилась все более современной. В начале 1990-х гг. переход к рыночной экономике и приватизация государственных предприятий сопровождались перепрофилированием производства некоторых из них. 28 сентября 1993 года было учреждено АООТ «Комплекс по производству железобетонных изделий ЖБК», директором которого был назначен В.В. Елисеев. Предприятие 
размещалось на площадях бывшей производственной базы треста «Запсибгидрострой», построенной 23 июля 1978 года и введенной в эксплуатацию 30 марта 1983 года. Первоначально основой номенклатуры ее производственной программы была продукция, предназначенная для жилищного строительства в кирпичном исполнении: фундаментные блоки, перемычки, прогоны, балконные плиты. Главными потребителями этих изделий были СГС, СНГ, СГП, ССТ и другие строительные и хозяйственные организации. В 1995-1996-х гг. производственные приоритеты были отданы продукции, предназначенной для дорожного строительства и благоустройства города. Она включала в себя бордюры, лотки, колодцы, осевой барьер безопасности и другие важные элементы сооружения дорожного покрытия. Основными заказчиками ЖБК стали САД, МП ДРСУ, ДСТ-1, Автодор - М. Постоянный контроль за выпуском продукции собственной лабораторией, аттестованной Госстандартом, позволил добиться ее высокого качества, особенно для дорог и благоустройства, где главным показателем является морозостойкость.

Кроме этого, в ходе обустройства ряда улиц Сургута тогда вводилось новшество: вместо бетонных бордюров устанавливались ограждения из гранитного камня. Их стоимость была в два раза выше стоимости изделий из бетона, но долговечность и возможность перестановки предопределяли более высокую экономическую эффективность использования таких элементов дорожного строительства (20).

В 1999 году начальник Управления транспорта и связи городской администрации Юрий Колисниченко с гордостью говорил о предстоящем открытии автомобильного движения на реконструированной улице Гагарина, о завершении строительства дамбы через Сайму, о практическом завершении обустройства тротуаров и освещения на улице Мелик-Карамова, открытии второго участка Комсомольского проспекта, трассируемого через 25 микрорайон на соединение с улицами Северной и Ленина, интенсивных дорожно-строительных работах на Пролетарском проспекте, которому предстояло новым дорожным полотном дотянуться до улицы Щепеткина и Речного вокзала. В конце 1990-х гг. впечатляющий объем дорожностроительных работ осуществлялся на улицах Кукуевицкого и Магистральной, были приведены в порядок улицы Губкина и Энтузиастов, а для приведения в эксплуатационное состояние улицы Маяковского недоставало только сооружения ливнесборной системы (21). 
В 1990-х гг. заметно улучшалось дорожное полотно не только на улицах в центре города, но и на его периферии. В 1999 году был закончен ремонт улицы Озерной и других автомобильных дорог Черного Мыса. Важное значение для отвода грузового транзитного транспорта из центра Сургута имел ввод в эксплуатацию транспортной магистрали по улице Профсоюзной, построенной в 1998 году и, по выражению Ю. Колисниченко, «доведенной до ума» в 1999 году (22).

Для транспортной развязки на окраине микрорайона нефтяников большую роль играла появившаяся новая улица, названная в честь одного из главных строителей города И.А. Киртбая. Влево от этой улицы уходила пока не завершенная объездная автодорога, которой суждено было в последующие годы пересечь протоку Боровую, уйти в сторону проспекта Набережного и по пойме вдоль Оби соединиться с улицей Югорской. Улица Магистральная найдет продолжение на пойме Оби и замкнется на восточную объездную дорогу. Так в Сургуте в соответствии с особенностями городской застройки формировалась радиально-кольцевая схема улично-дорожной сети.

По мере расширения дорожного строительства в Сургуте актуализировались вопросы организации работы автотранспорта. Очень важное значение для формирования города и его последующего развития имело транспортное обслуживание населения. Впервые автобусное сообщение в Сургуте было открыто в 1958 году. Маршрут проходил от Черного Мыса до Саймы (23). Его обслуживанием занималась Сургутская электростанция (24). Автоколонна, специально занимающаяся пассажирскими перевозками сургутян, была создана в 1962 году во главе с Л.В. Пешевым. Она являлась подразделением Ханты-Мансийской транспортной конторы Тюмень (26).

Из-за отсутствия ремонтной базы, недостаточного снабжения запасными частями, плохих дорожных условий ее руководитель Л. Пешев подвергался постоянной критике. «Автобусы часто сходят с линии, нарушается график из-за вынужденных поломок. По халатности шоферов автобусы запаздывают с выходом на линию или не укладываются в составленный график», - отмечалось в выступлениях делегатов 10-й сессии 8-го созыва поселкового Совета в ноябре 1962 года (27). Ежегодно у автобусов ломалось по 30-40 мостов ходовых агрегатов (28), коэффициент технической готовности автотранспорта составлял в 1962 году 52\%, а в 1963 году - 65\% (29), т.е. на линию выходила половина имеющегося в городе «автобусного парка». Тем не менее при очень плохом состоянии автотранспорта план по перевозке пассажиров автохозяйство во 
главе с Л. Пешевым выполняло на 130\% и более процентов (3О). Уже в 1963 году среднемесячная численность перевезенных пассажиров составила 154600 человек, т.е. в месяц на один автобус приходилось 17177 человек, а в день - 572 пассажира на один автобус при среднем расстоянии проезда пассажирами в 24 км (31).

Учитывая, что вновь созданная автоколонна не имела производственной базы в условиях роста интенсивности пассажирских перевозок, Сургутский исполком поссовета 16 января 1963 года принял решение «отвести земельный участок площадью 1,8 га под строительство гаражей и ремонтных мастерских из земель бывшей территории МТС» (32), а в декабре того же года обратился с просьбой к исполкому промышленного Совета депутатов трудящихся Тюменской области организовать в рабочем поселке Сургут автотранспортную контору и пополнить в 1964 году ее парк пятью автобусами ПАЗ-652. Кроме этого, Сургутский поселковый исполком просил поставить в рабочий поселок пять автомобилей ГАЗ-51, два автомобиля ГАЗ-63, три автомобиля ЗИЛ-157, пять самосвалов ЗИЛ-164, бензовоз на базе ЗИЛ-157 и пять таксомоторов «Волга» М-51. Особо важное значение имела просьба о выделении средств на строительство автогаража на 20 машино-мест и авторемонтной мастерской на 5 машино-мест (33).

Автотранспортное предприятие было создано. В конце 1964 года автоколонна в Сургуте располагала 14 автобусами, 6 грузовыми машинами ГАЗ-51 и двумя таксомоторами. Однако из 14 автобусов 5 не выходили на линию из-за отсутствия водителей и неисправностей. Грузовой транспорт использовался в основном торгующими организациями. Из-за нехватки рабочих затягивался ремонт гаража. В 1965 году автохозяйство работало плохо. План пассажирских и грузовых перевозок в приведенных тоннокилометрах выполнен на 73,3\%, а по доходам - на 72,3\%. Себестоимость автоперевозок была завышена на 7,2 тыс. рублей, допущен относительный перерасход фондов заработной платы на сумму 4,6 тыс. рублей, пережог бензина составил 108 тыс. литров, рост средней заработной платы обгонял рост производительности труда на $4,8 \%$, за год было получено убытков на сумму 6,6 тыс. рублей при плановой прибыли 4,9 тыс. рублей. Основной причиной неудовлетворительного выполнения плана явились простои машин. Коэффициент выпуска автомобилей на линию составил 0,358 , в то же время простой по разным причинам составил 64,2\% календарного времени, в том 
числе по причине неисправного состояния 31,2\%. Показатели использования автомобилей на линии также были крайне низкими. Продолжительность работы на линии легковых такси составила 5,8 часа, грузовых - 6,5 часа, автобусов 10,9 часа в день. Оставались нерешенными вопросы укрепления производственной базы, снабжения запасными частями для ремонта автомобилей, создания нормальных условий для работы. Утепленные гаражи и мастерские не строились, автомобили стояли и ремонтировались под открытым небом. В силу этого была велика текучесть рабочих кадров, особенно шоферов и ремонтных рабочих. Она составила в 1965 году 73\%. На предприятии не хватало 14 водителей (34).

Известно, что в декабре 1963 года в Сургутском районе автомобильный парк насчитывал 276 автомобилей и 232 трактора, в том числе в Сургуте имелось 133 автомобиля и 83 трактора (Зб). Поэтому злободневной становится проблема соблюдения правил дорожного движения, сокращения числа дорожно-транспортных происшествий, которые в последний год участились в Сургуте. В этой связи исполком Сургутского районного Совета депутатов трудящихся 4 декабря 1963 года отмечал на своем заседании, что «шофер автотранспортной колонны, будучи в нетрезвом состоянии, наехал на ученика Сорвина. Шофер Сургутской экспедиции в нетрезвом состоянии сбил машиной несколько телеграфных столбов, сломал переходный мостик. Многие водители нарушают правила, допуская перевозки в кузовах грузовых автомобилей людей и травмируя их». Особенно беспокоило депутатов то, что «водители не соблюдают скорость движения на перекрестках, возле школ и детских учреждений, подвергая тем самым детей смертельной опасности». В целях исключения аварий на автотранспорте исполком райсовета решил: «Вступить в ходатайство перед облисполкомом иметь в штате отделения милиции с 1 января 1964 года должность автоинспектора» (37). Из документов известно, что в 1965 году исполком Сургутского городского Совета просил «автоинспекторат усилить контроль за соблюдением правил дорожного движения водителями машин. Для чего привлечь общественных инспекторов и строго наказывать нарушителей» (38).

Особенно болезненно сургутяне воспринимали недостатки в организации движения автобусов в городе, когда «в морозы на автобусных остановках скапливалось много народу и тратилось по 30-40 минут на их ожидание». 
Много нареканий вызывали простои автомобилей и другой транспортной техники из-за отсутствия мастерских для проведения монтажных работ и технического обслуживания машин в автогараже (39).

Сургутский комитет КПСС вынужден был брать на себя непосредственные хозяйственные функции по обеспечению транспортных предприятий дорожными механизмами, автомобилями, тракторами, бульдозерами и экскаваторами. В 1969 году Сургутский горком КПСС, серьезно обеспокоенный организацией транспортного обслуживания в городе, убедительно просил горьковскую контору Главснабсбыта рассмотреть вопрос отгрузки 7 автобусов ПАЗ-672 в Сургут не в октябре, а в первой половине сентября 1969 года (40).

Развернувшаяся в 1960-е гг. под руководством Сургутского городского комитета партии и исполкома Совета депутатов трудящихся работа по улучшению производственной деятельности предприятий транспорта в Сургуте давала хорошие результаты. Были построены новые механические мастерские, ремонтные цеха, гаражи, в которых было установлено самое современное оборудование. Организация доставки народнохозяйственных грузов и пассажирских перевозок в городе значительно улучшилась.

О работе сургутских водителей и кондукторов тепло отзывались горожане: «Не первый год по улицам Сургута ходят автобусы. Теперь не надо тратить много времени и сил, чтобы попасть из одной части поселка в другую. Какие-нибудь 15-20 минут - и вы на пристани, за 5-7 минут можно от почты доехать до средней школы». «Строго по расписанию водит автобус молодой шофер Аркадий Уханов. Когда он на смене, в автобусе всегда чисто. Сам водитель всегда опрятно одет, вежлив с пассажирами» (41). «Хорошо ехать в автобусе, когда работает кондуктор Васса Дмитриевна Семенова. Никогда не услышишь грубого слова, и всем она приветлива, и каждому внимательна...» писали в редакцию районной газеты сургутяне (42).

Уже в 1969 году исполком городского Совета депутатов трудящихся утвердил новый маршрут автобусного движения в Сургуте. Любопытно проследить, что не только увеличение автобусных остановок, которых в 1969 году уже насчитывалось 30 единиц, но и их переименование отражало процесс благоустройства и социализации города. Например, остановка «Райисполком» 
стала «Площадью Гагарина», «Стройка» стала «Микрорайоном геологов», «СУ-16» - «Заводом ЖБИ» (43).

Заметно возросли масштабы производственной деятельности городской автотранспортной конторы. Если в 1970 году на Сургутском автотранспортном предприятии работало 85 человек, то в 1975 году его контингент насчитывал 431 специалиста, водителя и работника обслуживающего персонала. Были открыты филиалы сургутского автохозяйства в Нефтеюганске и Нижневартовске (44).

Большим стимулом для развития городского автотранспортного предприятия стало строительство Сургутской ГРЭС. Организация перевозок рабочих и специалистов потребовала выделения дополнительных значительных ассигнований для приобретения автобусов и других транспортных средств. Пик развития автопредприятия приходится на 1986-1987-е гг. Тогда в нем насчитывалось более 700 единиц техники. Кроме энергетиков, оно активно обслуживало нефтяников и строителей.

Однако в ходе реформ Минавтотранс стало терять свою роль монополиста в сфере продаж и распределения автомобилей. На рынке появилась свободная техника, которую стали приобретать предприниматели, а автотранспортный парк сургутского предприятия стал заметно сокращаться. В 1997 году в нем насчитывалось только 325 транспортных единиц, из которых около 70 требовали списания (45).

Тем не менее, имея надежную производственную базу, включающую в себя 4 комплекса по ремонту подвижного состава автотранспорта, оснащенную современным оборудованием, муниципальное предприятие «СПОПАТ» в 1997 году обслуживало 33 маршрута, в том числе 20 городских, 3 пригородных, 3 междугородных, 7 сезонных. Протяженность маршрутной сети насчитывала 770 км. Ежедневно 2100 автобусных рейсов перевозило 74000 пассажиров при регулярности движения 95,6\%. Коэффициент полезности при этом составлял 0,778. В транспортном процессе принимало участие 1100 человек, в том числе 925 водителей и рабочих. 230 водителей за работу без аварий были награждены почетными знаками (46).

Пассажирское автотранспортное предприятие являлось единственным специализированным предприятием в Сургуте, осуществлявшим пассажирские перевозки. Однако, кроме него, большое количество людей перевозили и ведомственные автохозяйства. О характере их деятельности можно судить на основе данных таблицы 14 (47). 
Таблица №14

Состояние пассажирских перевозок в 1970-1975-е гг.

\begin{tabular}{|l|c|c|}
\hline Единицы измерения & 1970 & 1975 \\
\hline Количество населенных пунктов, обслуживаемых транспортом & 2 & 7 \\
\hline общего пользования & 2 & 1 \\
\hline ведомственным транспортом & - & 6 \\
\hline Протяженность дорог, км & 121 & 282,5 \\
\hline в том числе с твердым покрытием & 77 & 232,5 \\
\hline в том числе городских & 56 & 74,5 \\
\hline из них обслуживаемых дорожными организациями & & 208 \\
\hline Количество маршрутов & 1 & 8 \\
\hline в том числе сезонного действия & 1 & \\
\hline Количество перевезенных пассажиров & 5806 & 20246 \\
\hline в том числе автопассажирским предприятием АТК «Главтюменнефтегаза» & 477,3 & 1035,7 \\
\hline
\end{tabular}

Из таблицы видно, что протяженность дорог с твердым покрытием увеличилась в 1970-1975-е гг. с 56 до 74,5 км, т.е. на 32\%. Число перевезенных пассажиров только одной АТК «Главтюменнефтегаза» увеличилось с 477,3 до 1035,7 тыс. человек, т.е. более чем на $100 \%$.

Интенсивность эксплуатации дорог приводила к тому, что в 1975 году $60 \%$ их протяженности требовали ремонта. Неудовлетворительное состояние магистральной инфраструктуры предопределяло большую часть поломок автомобилей и сход их с линий. Слабым звеном в обустройстве автобусных маршрутов являлось отсутствие оборудованных автобусных остановок и павильонов, съездных площадок (48).

Для ведомственных транспортных организаций, осуществлявших перевозку людей к месту работы на длительные расстояния, эта дорожная ситуация имела особенно печальные последствия. Они располагали автобусным парком, в 3 раза превышающим автобусный парк Сургутского автопассажирского предприятия. Однако большая часть машин, задействованных в перевозке вахт, из-за дефицита автобусов представляли собой переоборудованные автомобили и не отличались высокой комфортностью. Следует добавить, что этот многочисленный машинный парк включал в себя 19 моделей автомобильного транспорта, что существенно затрудняло их техническое обслуживание и ремонт (49).

Очень сильно усложняло транспортировку людей к месту работы отсутствие благоустроенного городского автовокзала. Автобусная станция 
имелась тогда только в микрорайоне НГДУ и находилась в одноэтажном деревянном помещении площадью $120 \mathrm{M}^{2}$, включавшем диспетчерскую и небольшой зал ожидания. Расположение посадочной площадки на проезжей части улицы рядом с «вокзалом», небольшая площадь комнаты ожидания существенно затрудняли осуществление централизованных перевозок и ставили перед заказчиками дополнительные трудноразрешимые задачи (50).

Таким образом, в процессе строительства автомобильных дорог и расширения автомобильного парка в 1960-1990-е гг. транспортная инфраструктура городов ХМАО-Югры заметно улучшалась. Особенно очевидно это прослеживается в Сургуте, где в 2000 году автомобильный парк города составил 113 тыс. единиц. На 22 городских маршрутах было задействовано 180 автобусов, которые перевозили в среднем 50 млн. пассажиров в год (51).

В ходе благоустройства новых городов, расположенных на территории нефтедобывающего района Среднего Приобья, весьма актуальной проблемой являлось обеспечение населения водой. Материковый автономный округ не испытал потребности в ней. Прогнозы ресурсов подземных вод ХМАО-Югры включали 94657 тыс. $\mathrm{M}^{3} /$ сутки, что составляло 66,39\% общего объема прогнозируемых подземных вод Уральского федерального округа и 10,88\% их общероссийских ресурсов. Обеспеченность населения округа водой речного

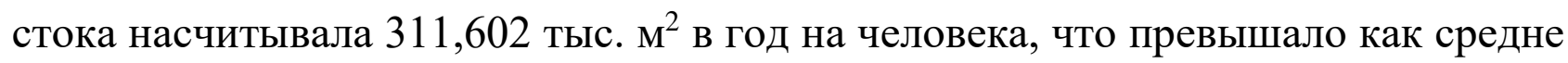
российские показатели $\left(31,717\right.$ тыс. $\mathrm{M}^{3}$ в год на человека) почти в 10 раз, так и показатели Уральского федерального округа (66,33 тыс. м³ в год на человека) почти в 5 раз. По этому показателю ХМАО-Югра занимал второе место среди регионов федерального округа после Ямало-Ненецкого автономного округа (52). Однако речная вода Среднего Приобья в зоне активного нефтегазового освоения и градостроительства была низкого качества. Это являлось следствием не только техногенного влияния, но и природных факторов округа: высокого содержания в воде растворенных органических веществ, повышенной цветности, очень высокой концентрации железа и марганца, что было обусловлено их интенсивным вымыванием из подступающих пород. На эти факторы, отмеченные еще в XIX веке, пристальное внимание обращают и современные исследователи (53).

Составляющие немалую часть водных ресурсов болотные воды провоцировали еще большую кислотную активность среды. Они содержали более высокое, чем в реках и озерах, содержание органических веществ, 
а также в силу весенних разливов, на время соединяющих многие водоемы друг с другом в единое водное пространство, создавали благоприятные условия для активной миграционной подвижности ряда химических элементов. В районе акватории строящихся Нефтеюганска, Сургута и Пыть-Яха, например, имелось превышение допустимых норм кремния, аммонийного азота, присутствовали в воде метан, свободная углекислота, большое количество железа. Это усугублялось губительными техногенными последствиями промышленного освоения севера Западной Сибири. В 1970-е гг., после завершения строительства и ввода в эксплуатацию ГРЭС-1 и ГРЭС-2, одним из основных источников загрязнения окружающей среды в районе бассейна Средней Оби стали их сбросовые воды. Основными видами отрицательного воздействия ГРЭС на водные ресурсы стало потребление ими большого объема воды для охлаждения оборудования и сброс промывочных вод технологических систем. В 1993 году объем сброса ГРЭС-1 и ГРЭС-2 составил соответственно 3425 и 171 тыс. м $^{3}$ воды. Большая доля сброса неочищенных вод приходилась также на долю рыбокомбината. В 1996 году объем его сброса составил 120 тыс. м³ (54).

В Среднем Приобье положение осложнялось также тем, что спад производства в 1990-е гг. стал причиной закрытия ряда предприятий, имеющих суда речной флотилии. Часть оставшихся без обслуживания судов, барж и других плавсредств, в том числе груженых и заправленных топливом, затонули. В результате этого ржавеющие танкеры и баржи стали источником загрязнения этой акватории. Очень большой разлив нефтепродуктов произошел в районе реки Черной.

Кроме того, на качестве ее воды отрицательно сказывалось множество экологических и санитарно-гигиенических нарушений бытовой жизни. В Сургуте, как самом большом строящемся городе, это особенно четко просматривается. Здесь острота данного вопроса усиливалась доставшимся ему в наследство антисанитарным состоянием рабочего поселка, на базе которого строился город.

Его неудовлетворительное санитарно-гигиеническое состояние ставило под угрозу в целом санитарно-эпидемический режим населенного пункта, так как водоснабжение рабочего поселка осуществлялось из реки Бардаковки. Это происходило в условиях, когда «в отведенные для свалки места нечистоты, мусор и навоз не вывозились, а сваливались на берегу речек Бардаковки, Саймы и Черной, которые служили источником питьевого водоснабжения населения. Навоз и мусор с территории поселка рыбоконсервного завода сваливался в 
овраг по улице Пионерской», - отмечалось в документах Сургутского райисполкома (55).

В январе 1963 года бюро Тюменского областного комитета специально указывало Сургутскому районному исполнительному комитету трудящихся на то, что «санитарное состояние населенных пунктов в районе остается неблагополучным. Не проводится своевременная очистка населенных мест, не организовано благоустройство свалки и мест сброса нечистот. Отсутствуют ассобазы, если не считать одну ассенизаторскую бочку на рыбоконсервном комбинате. Нет в достаточном количестве надворных санузлов. Воды хозяйственно-бытовых предприятий и учреждений, в том числе и в районном центре, сбрасываются в водоемы в непосредственной близости от мест водозабора» (56).

В 1964 году, по сравнению с 1963 годом, число больных острой дизентерией в Сургутском районе возросло с 36 до 522 чел., а эпидемическим паротитом - со 163 до 333 чел.(57).

В 1960-е гг. по мере расширения застройки города работа по его благоустройству начинает приобретать целенаправленный и последовательный характер. Тюменский областной комитет КПСС выражал серьезную обеспокоенность продолжающейся застройкой Сургута домами в деревянном исполнении без необходимого комплекса коммунальных удобств и современных требований градостроения. При таком строительстве отсутствовали инженерные коммуникации водопровода и канализации, не осуществлялось благоустройство территории. 21 июня 1968 года обком КПСС принял решение «осуществлять дальнейшую застройку городов Сургута и Нефтеюганска только в многоэтажном капитальном исполнении». На «Главтюменнефтегаз» были возложены функции единого заказчика по строительству в этих городах жилья и общегородских инженерных коммуникаций. На осуществление этих работ выделялись дополнительные финансовые средства (58).

Заметный вклад в строительство инженерных коммуникаций и тепловых сетей, ремонт зданий в Сургуте внес созданный в феврале 1966 года в составе Главтюменнефтегазстроя трест специализированных работ «Спецгазстрой» во главе с управляющим В.Г. Дурново. Еще в 1967 году в поселке нефтяников при плане 530 тыс. рублей, выделенных на строительство очистных сооружений и 
канализации, трестом было освоено 683 тыс. рублей, в поселке геологов таких работ было произведено на 303 тыс. рублей, в поселке строителей - на 45 тыс. рублей. Кроме этого, были подготовлены 3 насосные станции и радиальные отстойники (59).

Однако темпы и объемы строительства канализационных сетей и монтажа очистных сооружений были недостаточными и отставали от решения объективных проблем создания и совершенствования инженерно-технической инфраструктуры бывшего рабочего поселка. Ситуация осложнялась тем, что, в силу сложных технологических, экологических и ряда других особенностей строительства объектов городских очистных сооружений, подрядные организации не брали на себя ответственность за их строительство и последующую эксплуатацию (60). Особенно острой она являлась для ввода в строй санитарно-технических магистралей микрорайонов геологов и строителей. В 1971 году городское руководство выражало свое неудовлетворение ходом строительства КНС-1, учитывая то, что вся внутриквартальная работа в микрорайоне строителей была выполнена еще год назад. Результатом медленного строительства канализационной и водоочистительной систем в городе стала вспышка в Сургуте 28 августа - 4 октября 1971 года паратифа «Б». По разным оценкам, им переболело от 75 до 106 человек (61). Причиной его оказалось нарушение санитарногигиенического режима снабжением доброкачественной питьевой водой на Сургутском молокозаводе, располагавшемся в небольшом помещении на захламленной территории.

Из-за недостатка мест в больницах города пострадавших вынуждены были разместить в подъезде подготовленного к сдаче крупнопанельного дома. Во главе с главным эпидемиологом страны в Сургут прибыла авторитетная комиссия. Причины и последствия сургутской эпидемии стали предметом специального обсуждения на заседании Президиума Совета министров РСФСР (62).

Принятые решения способствовали активизации деятельности строительных и хозяйственных организаций по обеспечению в городе благоприятной санитарно-эпидемиологической обстановки. Ответственность за качественную питьевую воду, поступающую в квартиры сургутян, взяли на себя руководители «Сургутнефтегазстроя», преодолевшие многочисленные 
трудности в ходе строительства жизненно необходимых городу водозаборов, очистных сооружений и водных трубопроводов (63).

В округе общая протяженность водных артерий составляла несколько десятков тысяч километров. В конце 1990-х гг. более 70\% магистральных канализационных коллекторов в ХМАО-Югре имели износ более $50 \%$. Внутриквартальные сети были изношены на $60 \%$. В городах Урай, Лангепас, Лянтор, Нефтеюганск, Пыть-Ях износ сетей составлял 70-76\%. Свыше 400 км. канализационных сетей нуждались в срочном ремонте или замене (64).

Администрация округа предпринимала действенные меры по нейтрализации отрицательных последствий ухудшающейся экологической ситуации. Плодотворным шагом руководства ХМАО-Югры на пути обеспечения экологической безопасности в регионе стало принятие программы «Чистая вода». В ходе ее реализации в департаментах новых городов формировались отделы земледелия, природопользования и экологии. Они комплектовались опытными, квалифицированными специалистами. Среди них особенно высокой компетентностью и активностью отличался руководитель Сургутского отдела во главе с В.А. Браташовым. Он возглавил работу по осуществлению комплексного обследования состояния существующей системы водоочистки, определив основные направления реконструкции ее сооружений (65). В Сургуте она началась в 1995 году и велась даже более активно, чем в столице округа Ханты-Мансийске, где к ней приступили на год позже, в 1996 году. В масштабах ХМАО для ее реализации в 1998-2004-х гг. было финансировано 7,6 млрд. руб. (66).

В результате проведенной реконструкции очистных сооружений производительность КОС увеличилась. В Сургуте она возросла до 150 м $^{3}$ воды в сутки. Канализационные стоки попадали на очистные сооружения по напорным коллекторам с 19 станций. Они проходили двухступенчатую очистку, механическую и биологическую. Это способствовало заметному улучшению сточных вод (67).

Не столь благополучно этот вопрос решался в Нефтеюганске. Здесь реконструкция водоочистных сооружений затянулась до 2015 года. Качество воды контролировалось 12 раз в год на 26 гидрохимичеких постах. О ее качестве можно судить на основе данных таблицы № 15 (68). 
Таблица № 15

Сведения о качестве питьевой воды, подаваемой абонентам с центральных систем водоснабжения города Нефтеюганска

\begin{tabular}{|c|c|c|c|}
\hline $\begin{array}{l}\text { № } \\
\text { П/II }\end{array}$ & Показатели & $\begin{array}{c}\text { Результат } \\
\text { исследований }\end{array}$ & $\begin{array}{c}\text { Нормативы (предельно } \\
\text { допустимые концентрации) }\end{array}$ \\
\hline 1 & Запах при 20 градусах & 1 & не более 2 баллов \\
\hline 2 & Запах при 60 градусах & 2 & не более 2 баллов \\
\hline 3 & Цветность & 21 & не более 20 (35) град. \\
\hline 4 & Мутность & 0,8 & не более 1,5 (2) мг \\
\hline 5 & Привкус & 2 & не более 2 мг \\
\hline 6 & $\begin{array}{l}\text { Окисляемость } \\
\text { перманганатная }\end{array}$ & 4,46 & не более 5 мг \\
\hline 7 & Водородный показатель & 7,2 & от 6 до 9 единиц \\
\hline 8 & Жесткость общая & 1,42 & не более 7 (10) мг/дмз \\
\hline 9 & Хлориды & 57,4 & не более 350 мг \\
\hline 10 & Сульфаты & 3,4 & не более 500 мг \\
\hline 11 & Железо & 1,0 & не более 0,3 (1) мг \\
\hline 12 & Нефтепродукты (суммарно) & 0,017 & не более 0,1 мг \\
\hline 13 & Медь (суммарно) & 0,02 & не более 1 мг \\
\hline 14 & Нитраты & 0,1 & не более 45 мг \\
\hline 15 & Нитриты & 0,032 & не более 3 мг \\
\hline 16 & Марганец & 0,023 & не более $0,1(0,5)$ мг \\
\hline 17 & Аммиак (по азоту) & 1,7 & не более 1,5 (2) мг \\
\hline 18 & $\begin{array}{l}\text { Общая минерализация } \\
\text { (сухой остаток) }\end{array}$ & 303,067 & не более 1000 (1500) мг \\
\hline 19 & Цинк & 0,016 & не более 5 мг \\
\hline 20 & Свинец & 0,003 & не более 0,03 мг \\
\hline 21 & Фенол & 0,0005 & не более 0,001 мг \\
\hline 22 & $\begin{array}{l}\text { Поверхностно-активные } \\
\text { вещества (ПАВ) }\end{array}$ & 0,3 & не более 0,5 мг мг \\
\hline 23 & Ртуть & 0,00004 & не более 0,0005 мг \\
\hline 24 & Кадмий & 0,0002 & не более 0,001 мг \\
\hline 25 & Мышьяк & 0,005 & не более 0,05 мг \\
\hline 26 & Формальдегид & 0,02 & не более 0,05 мг \\
\hline
\end{tabular}

Материалы таблицы свидетельствуют о соответствии в основном результатов гидрохимических проверок нормам предельно допустимой концентрации вредных веществ в водоснабжении города Нефтеюганска. Из-за неспособности очистительных систем нейтрализовать губительный эффект 
железных примесей, превышавших допустимые нормы на 0,7 мг, и ряда других причин руководители города активно вели работу по строительству новых очистительных сооружений.

В ХМАО-Югре альтернативный поверхностному забор воды осуществлялся из подземных горизонтов водозаборными скважинами. Объемы пресных подземных вод в регионах севера Западной Сибири были достаточно большие. В Нефтеюганском районе, например, их разведанные эксплуатационные запасы составляли 200 тыс. м³/сут., почти 1 тыс. м³/сут. на одного человека, а прогнозные ресурсы были еще больше - 6910 тыс. м³/сут. (69).

Ссылаясь на устное мнение специалистов, заметим, что качество воды, извлекаемой из артезианских колодцев, в некоторых районах округа было в ряде случаев не хуже, чем на «большой земле».

Тем не менее в подземных водах ХМАО-Югры повсеместно присутствовали в большой концентрации вредные вещества. Качество подземной воды во всех муниципальных образованиях округа не соответствовало требованиям СанПиН 2.1.4.1074-01 «Питьевая вода. Гигиенические требования к качеству воды централизованных систем питьевого водоснабжения. Контроль качества».

Качество подземной воды в Нефтеюганском районе представлено в таблице № 16 (70).

Таблица № 16

Качество подземной воды в Нефтеюганском районе

Нефтеюганск и Пыть-Ях

\begin{tabular}{|l|c|c|c|}
\hline \multicolumn{1}{|c|}{ Показатели } & Ед. изм. & Поверхностная & Подземная \\
\hline Водородный & $\mathrm{pH} \mathrm{7,17}$ & 7,52 & 6,3 \\
\hline Температура & $\mathrm{C}$ & 3 & 7 \\
\hline Запах при 20С & балл & 0 & 0 \\
\hline Запах при 60С & балл & 1 & 1 \\
\hline Цветность & град & 50 & 9 \\
\hline Мутность & мГ/д & 1,31 & 0,13 \\
\hline Перманганатная окисляяемость & м/д3 & 4,6 & 3,81 \\
\hline $\begin{array}{l}\text { Щелочность } \\
\text { Общая }\end{array}$ & моль & 3,88 & 1,29 \\
\hline Жесткость & моль 1,45 & 1,78 & 5,6 \\
\hline Сухой остат & мг & 203 & 154 \\
\hline
\end{tabular}


ГОРОДСКОЕ СТРОИТЕЛЬСТВО В ХАНТЫ-МАНСИЙСКОМ

АВТОНОМНОМ ОКРУГЕ - ЮГРЕ (к.1950-х - сер.1990-х г2.)

\begin{tabular}{|l|c|c|c|}
\hline Хлорил-ион & мг & 52,45 & 11,26 \\
\hline Сульфа-ион & мг & 0.97 & 10,57 \\
\hline Полифосфаты & мг & 0,123 & 0,12 \\
\hline Нитрит-ион & мг & 0,009 & 0,012 \\
\hline Нитрат-ион & мг & 0,5 & 0,5 \\
\hline Аммиак & мг & 2 & 1,04 \\
\hline Железо общее & мг 1,8 & 0,2 & 10,4 \\
\hline Алюминий & мг & 0,02 & 0,11 \\
\hline Хлоростат & мг & 0,46 & 0,37 \\
\hline Нефтепрод. & мг & 0,056 & 0,037 \\
\hline
\end{tabular}

В Нефтеюганском районе питьевая вода извлекалась главным образом из Новомихайловского и Атлымского водоносных горизонтов. В городе Нефтеюганске водозабор осуществлялся скважинами, расположенными в центральной части населенного пункта. Вода подавалась с глубины 300 м., производительность водозабора составляла 23,8 тыс. м³/сут. В Пыть-Яхе каналами подъема воды из подземных горизонтов служили пять водозаборов проектной мощностью 8,0 тыс. м³/сут. (71).

Данные таблицы № 16 свидетельствуют о том, что в Нефтеюганске и Пыть-Яхе извлекаемая подземная питьевая вода имела повышенные показатели по цветности, мутности, содержанию железа и других веществ. Подземные воды, как и поверхностные, перед подачей в водопроводные системы требовали глубокой очистки на инженерных сооружениях. Причем поверхностные воды ограничивались только такой очисткой, а подземные воды в соответствии с технологическими требованиями претерпевали еще и специальную подготовку.

Однако очистные сооружения, установленные в Нефтеюганске, и водоподготовка были малоэффективны, т.к. основывались на устаревших технологиях, транспортировка воды осуществлялась в коррозированных трубопроводах, системы обеззараживателей воды работали малоэффективно.

Низкое качество было характерно и для питьевой воды сургутян. В Сургуте концентрация железа в воде составляло 2,5 мг/л при нормативе 0,3 мг/л., имелось превышение аммонийного азота, кремния, присутствовали в воде и газы: метан, свободная углекислота. Кроме того, вода в Сургуте была весьма мягкая и имела желтый цвет. Газета «Вестник» так писала об этом в 1998 году: «Наблюдая за желтой ржавой массой, текущей из крана городской квартиры, я вспоминала водицу из колодца в алтайской деревушке» (72). Перед употреблением сургутскую воду необходимо было отстаивать. В 1997 году, по 
компетентному мнению специалистов, «очистные сооружения города уже на 100\% не отвечали санитарным требованиям» (73).

Для решения принципиальных технологических вопросов реконструкции системы водоочистки в Сургуте администрация города под руководством мэра города А.Л. Сидорова привлекала специалистов ведущих научных учреждений страны в области водоподготовки. Руководство города активно сотрудничало с Научно-исследовательским институтом коммунального водоснабжения и очистки воды Академии коммунального хозяйства им. Панфилова (74). Большой вклад в эту работу внес приглашенный администрацией из Казани в Сургуте посвятивший этому благородному делу больше шести лет Ю.В. Антонов. Именно благодаря его опыту была проведена основная реконструкция всех станций водоочистки, централизованно снабжавших город Сургут питьевой водой (75).

В 2000 году четыре водозабора города ежедневно поднимали из артезианских скважин 107,5 тыс. м $^{3}$ воды. После прохождения через специальные фильтры, состоящие из двухметрового слоя чистейшего кварцевого песка, привезенного в Сургут с Урала, и установки кислородного окисления железа содержание этого металла в воде снижалось до 0,3 мг/л, что вполне соответствовало санитарным нормам (76).

В 1999 году Городской думой было принято решение отказаться от обеззараживания водопроводной воды хлором и перейти на обеззараживание ультрафиолетовым излучением. Этот метод очистки является самым эффективным современным способом. Применявшийся ранее сброс хлорированной воды наносил ущерб экологии. Некоторое время вместо хлора использовали хлористые соединения кальция, но и это не удовлетворяло экологов. В результате было закуплено оборудование для обеззараживания воды при помощи ультрафиолетовых лучей, что в значительной мере способствовало превращению потребляемой в Сургуте воды в самую чистую воду Тюменской области (77).

К концу 1999 года в Сургуте был преодолен казавшийся ранее недоступным барьер очистки воды от фтора. К этому времени питьевая вода в городе соответствовала санитарно-биологическим требованиям. Практически все горожане, охваченные центральным водоснабжением, потребляли питьевую воду в пределах санитарных норм (78).

Отмечая эффективную работу по очистке воды в городе Сургуте, следует указать на неудовлетворительное состояние систем водоснабжения и качества 
питьевой воды во многих крупных городах ХМАО-Югры. В ходе глубокого анализа этого вопроса исследователи А.Ю.Солодовников и Л.А. Солодовников показали состояние водопроводов питьевого снабжения в Нефтеюганске, представленное в таблице № 17 (79).

Таблица № 17

Состояние водопроводов питьевой воды в Нефтеюганске и Пыть-Яхе

\begin{tabular}{|l|c|c|c|c|}
\hline \multicolumn{1}{|c|}{ Показатели } & Год & Нефтеюганск & Пыть-Ях & Нефт. -он. \\
\hline $\begin{array}{l}\text { Колич. водопр., не соотв. } \\
\text { сан-эпид.нор. }\end{array}$ & 2012 & 100 & 100 & 81,3 \\
\hline Из-за отсутст. зон сан. охр. & 2012 & 100 & 25 & 100 \\
\hline $\begin{array}{l}\text { Из-за отсут.необх. комп. } \\
\text { очист. сооруж. }\end{array}$ & 2012 & 50 & 50 & 100 \\
\hline $\begin{array}{l}\text { Из-за отсут. обеззаражив. } \\
\text { установок }\end{array}$ & 2012 & 50 & 0 & 100 \\
\hline
\end{tabular}

Материалы таблицы свидетельствуют о том, что, несмотря на проделанную работу по обновлению водопроводов питьевого снабжения в исследуемый период, даже к 2012 году не удалось в целом по округу в городах ХМАО-Югры полностью решить эту задачу. Признать её удовлетворительной повсеместно во всех муниципалитетах региона оснований нет.

По данным Управления федеральной службы по надзору в сфере защиты прав потребителей и благополучия в ХМАО-Югре, как видно из таблицы № 18 на примере городов Нефтеюганска и Пыть-Яха, вода в значительной степени не соответствовала гигиеническим требованиям по санитарно - химическим показателям. При этом по микробиологическим показателям воды в основном были чистые (80).

Таблица № 18

Доля проб питьевой воды, не соответствующей гигиеническим нормам

\begin{tabular}{|l|c|c|c|c|c|c|}
\hline Муниципальные & \multicolumn{7}{|c|}{ По санитарно-хим. показ. } & \multicolumn{1}{c|}{ По микробиологич. показ. } \\
\cline { 2 - 7 } организации & 2012 & 2013 & 2014 & 2012 & 2013 & 2014 \\
\hline Нефтеюганск & 93,2 & 100 & 100 & 0,8 & 0,8 & 0,8 \\
\hline Пыть-Ях & 83,9 & 71,8 & 80 & 0,7 & 0,8 & 0,0 \\
\hline Нефт. р-он & 100 & 100 & 100 & 0 & 0 & 0 \\
\hline \multicolumn{7}{|c|}{ Поверхностные источники } \\
\hline Нефтеюганск & 100 & 100 & 100 & 0 & 0 & 0 \\
\hline Пыть-Ях & 83,9 & 71,6 & 80 & 0,7 & 0,0 & 0,0 \\
\hline Нефт. р-он & 100 & 100 & 100 & 0 & 0 & 0,4 \\
\hline
\end{tabular}


Переход к индустриальной застройке северных городов весьма остро ставил вопрос об их озеленении. Они располагались в северной и средней подзонах таежных лесов, где преобладающими породами по запасу являются сосна обыкновенная - 45,8\% и кедр (сосна сибирская) - 23,6\%. Почти 50\% лесных земель являли собой заболоченные территории с резко континентальным климатом. Неслучайно участник Великой Сибирской экспедиции Герхард Миллер, работая над фундаментальным трудом «Описание Сибирского царства», объезжая эти места в период с 1733 по 1783 годы, особо подчеркивал, что могучие реки пользовались у местного населения глубоким почтением. Как было прослежено, нередко городки, служившие местом пребывания, были своеобразными столицами местных князьков, возникали и сохранялись в течение веков возле озелененных пространств (81).

Из-за сокращения лесов меняются не только гидротермические параметры в пределах вырубленного массива леса, но даже микроклиматические условия. Более того, отмечаются случаи изменения метеорологического режима: в последние годы скорости ветра в Западной Сибири возросли до параметров смерчей. В начале 2000 года в долине Оби мощный ураган повредил пихтовый лес на площади 800 га (82).

Территория ХМАО-Югры относится $\quad$ к зоне малоблагоприятных природных условий для проживания населения. Его суровые климатические условия усугубляются неблагополучными почвенными и экологическими факторами, связанными с крупномасштабным углеводородным загрязнением центральной части Западной Сибири. Это диктовало необходимость четко дифференцированной, функционально обоснованной системы озеленения бурно развивающихся городов северного региона. Именно тогда зеленые насаждения городов и прилегающих территорий могли бы выполнять свои основные функции: санитарно-гигиеническую, рекреационную, эстетическую и природоохранную, а используемые растения в полной мере проявлять свои разнообразные возможности: защитные, декоративные, фитонцидные и т.п. - в данных природно-климатических условиях. В соответствии с оптимальным рекреационным районированием города должны располагать зелеными зонами, лесопарками и природными парками, которые смогли бы удовлетворить спрос городского населения на рекреационные объекты. Городские леса и зеленые насаждения важно было сделать неотъемлемой частью градостроительной структуры городов ХМАО-Югры, обязательным элементом их городского ландшафта. Их креативные, санитарно-гигиенические и психофизиологические 
функции существенно возрастают в условиях севера, продуцируют кислород, ассимилируют углекислоту, осаждая пыль, газообразные химические вещества, микроорганизмы, радионуклиды. Неслучайно ветеран освоения Тюменского севера, первый заместитель министра строительства предприятий нефтяной газовой промышленности в 1982-1991-х гг. Г.И. Шмаль с горечью писал об этом, ссылаясь на пример Сургута: «В Сургуте смелее следовало бы осваивать для застройки пойменные территории реки Оби, а не вырубать для этого лесной массив в западной части города» (83).

Отмечая справедливость слов ветерана социального обустройства севера Западной Сибири, отметим, что в исследуемый период во многих городах ХМАО-Югры Сургуте, Нижневартовске, Покачи, Лангепасе и ряде других осуществлялась определенная целенаправленная работа по формированию в них зеленых зон и прогнозировалось создание в них единой системы озеленения, объединяющей внутригородские объекты озеленения с пригородными посредством бульваров и пешеходных маршрутов.

В Сургуте таежный лес вводился в город отдельными широкими массивами в ряде мест периферии создаваемых микрорайонов. В нем сохранившаяся зеленая зона простиралась на западе города, за парком нефтяников. Большие надежды сургутяне связывали с благоустройством самой большой по площади парковой зоны «Кедровый лог» в районе телестанции «Орбита», где располагались спортивные сооружения, стадион «Нефтяник», лыжная и конно-спортивная базы, детский дом «На Калинке», пансионат «Нефтяник» (84).

Также на северо-западе Сургута к вокзалу примыкал большой участок таежного леса. Сохранился лес и в районе грэсовского «пятачка». Имелись парковые зоны таежного леса и в центральных районах. Наиболее привлекательной для сургутян была неплохо обустроенная парковая зона, находившаяся в ядре города, в пойме речки Саймы. Однако другие зеленые массивы Сургута трудно было назвать парками. Это были немногочисленные участки девственного леса, чудом сохранившиеся во время массовой застройки города, которые некоторое время не имели даже определенного статуса.

Однако в 1970-1980-е гг. такая работа не носила системного характера и осуществлялась силами общественности. Целенаправленный и организованный характер она начинает приобретать в 1990-е и последующие годы. Им мы и посвятим дальнейшее исследование. 
Тогда в планах развития новых городов их озеленение стало занимать гораздо больше места, чем раньше. Например, в 1995 году городская администрация и управление по зеленому строительству в Сургуте приняли решение о создании парка памяти коренных жителей города на территории зеленого массива старого кладбища по улице Энергетиков. (85) По свидетельству заместителя главного архитектора города Сергея Соловьева, планировалось также создать зону отдыха в пойме реки Оби параллельно улице Мелик-Карамова. Предполагалось осуществить благоустройство сквера у пересечения проспектов Ленина и Мира (86).

Однако время шло, а в городе площадь земель таежного леса неуклонно сокращалась. В 1993-2002 гг. при сооружении таких линейных объектов, как нефтегазопроводы, ЛЭП и автодороги, было вырублено более 11,5 тыс. м древостоя на площади 133,38 га. Всего же за период с 1997 года по 2002 год площадь лесных земель города уменьшилась на 158 га. При этом было вырублено $12487 \mathrm{~m}^{3}$ древесины. Данные о вырубке лесов по годам представлены в таблице № 19 (87).

Таблица № 19

Объем древесины и площадь вырубленных лесов в Сургуте в 1997-2002 годы

\begin{tabular}{|c|c|c|c|c|c|c|c|c|}
\hline \multirow{2}{*}{ Год } & \multicolumn{2}{|c|}{$\begin{array}{c}\text { Сооружение коридора для } \\
\text { коммуникаций }\end{array}$} & \multicolumn{2}{c|}{$\begin{array}{c}\text { Строительство } \\
\text { объектов }\end{array}$} & \multicolumn{2}{|c|}{$\begin{array}{c}\text { Изыскательские } \\
\text { работы }\end{array}$} & \multicolumn{2}{c|}{ Всего } \\
\cline { 2 - 9 } & га & $\mathrm{m}^{3}$ & га & $\mathrm{M}^{3}$ & га & $\mathrm{m}^{3}$ & га & $\mathrm{M}^{3}$ \\
\hline 1997 & 15,11 & 1362 & - & - & - & - & 15,11 & 1362 \\
\hline 1998 & 45,30 & 5273 & 10,9 & 16 & 0,25 & 15 & 56,45 & 5304 \\
\hline 1999 & 9,20 & 153 & 0,09 & 10 & 0,32 & 19 & 9,611 & 182 \\
\hline 2000 & 1,53 & 230 & 2,82 & 16 & 0,63 & 44 & 4,98 & 290 \\
\hline 2001 & 51,85 & 3151 & 4,06 & 230 & 0,26 & 25 & 56,17 & 3406 \\
\hline 2002 & 10,39 & 1479 & 5,2 & 446 & 0,13 & 18 & 15,7 & 1943 \\
\hline Итого & 133,38 & 11648 & 23,07 & 718 & 1,6 & 121 & 158,0 & 12487 \\
\hline
\end{tabular}

Из таблицы видно, что главная причина вырубки лесов заключалась в необходимости расширения систем коммуникаций и строительства площадных объектов. В ходе их сооружения было вырублено древесины на площади 156,45 га объемом 123,6 м³. Меньший ущерб лесному фонду наносился при проведении изыскательских работ, соответственно 1,6 га и $121 \mathrm{~m}^{3}$.

В связи с вырубкой значительной части таежного леса во время застройки городов, повсеместной выторфовкой, нарушением тонкого почвенного покрова, 
повреждением корневой системы при массовом хождении, изменением уровня грунтовых вод такой лес подвергался рекреационной дегрессии. По данным Комитета по природопользованию и экологии администрации Сургута в 2002 году, 41,6\% общей площади городского леса была подвержена изменениям. В подросте и подлеске поврежденные и усыхающие экземпляры составляли 5-20\%. В древостое удельный вес больных деревьев вырос до 20\% их общего количества. Лесная среда деградировала на 2,5\% городской площади лесного массива. Здесь более 70\% леса требовало восстановления (88).

В связи с вырубкой таежного леса и отмиранием его изолированных участков в новых экологических условиях произрастания необходимо было заменять его и высаживать более стойкие и культурные лесные породы.

По своему функциональному назначению все насаждения в округе делились на три категории: 1-я - общего пользования (ОП), 2-я - ограниченного пользования (ОгрП) и 3-я - специального назначения $(\mathrm{CH})$. Организаторы стремились к тому, чтобы основу, костяк в городской системе озеленения составляли насаждения ОП, к которым относились парки, сады, скверы, бульвары, лесопарки как насаждения ОП массового посещения.

В Сургуте еще в далекие послевоенные годы бригады молодых рабочих проводили дренаж его территории, организовывали комсомольские «субботники», объявляли декады борьбы за его чистоту, прокладывали новые тротуары и озеленяли улицы. Как вспоминал И.П. Захаров, в то время появились в Сургуте березовые рощи и парки у черномысовской неполной средней и сургутской средней школ. Энтузиастами и организаторами этого дела были молодые учителя Евлалия Александровна Кошкарова, Нина Петровна Маковецкая, а также Владимир Степанович Кочетков, Андрей Николаевич Сибирцев, Виктор Павлович Бирюков, Александр Федорович Шандыров (89).

В 1949 году комсомольцы Сургута заложили Парк имени XI съезда ВЛКСМ. К сожалению, тому парку не суждено было разрастись. В 1990-е гг. его и березовую рощу средней школы № 1, взращенную комсомольцами сороковых-пятидесятых годов, активно вырубали под жилые дома богатых людей Сургута (90). Но традиции массового участия жителей в озеленении города сохранились и в 1990-е годы. Тогда регулярно стали проводиться месячники по благоустройству города, в ходе которых осуществлялась посадка насаждений, ремонт инженерных коммуникаций, очистка территории. Например, в мае 1997 года в ходе месячника был выполнен большой объем работ по благоустройству города. Его ход контролировали три рабочие группы. 
Победители получили ценные призы, финансированные из бюджета администрации (91). 25 сентября 1999 года более 150 сургутян приняли участие в посадке деревьев на участке площадью 20 тыс. м², подготовленном фирмой «Зеленстрой» (92). Однако такая работа по озеленению Сургута велась стихийно, преимущественно по инициативе администрации и общественности города в ходе благоустроительных мероприятий.

Старожилы Сургута помнят бескорыстную работу жителя города южанина Саши Магорамова, который в начале 1960-х гг. начал привозить из отпуска не фрукты, а семена трав, сам их рассаживал вдоль новых улиц. Его примеру последовали тысячи сургутян, сажая деревья и кустарники возле своих возведенных домов. Сегодня эти внутриквартальные посадки разрослись в некоторых местах города в тенистые рощи тополей, русских берез, ярких рябин и плакучих ив (93).

По мере увеличения масштабов городского строительства в городах нефтегазового освоения экологическая работа на их территории начинает приобретать системный характер. В 1993 году был создан Комитет природопользования и экологии администрации города Сургута (94). Его возглавил человек, по-настоящему преданный делу его благоустройства, В.А. Браташов. Он же был назначен начальником созданного позднее, в 1997 году, Департамента по землепользованию, природопользованию и экологии. Департаменту подчинялся и финансировался в части исполнения муниципальных функций Комитет по земельным ресурсам и землеустройству. Работа департамента осуществлялась особенно эффективно в 1997-2001 гг., когда В.А. Браташов являлся заместителем мэра города Сургута. Возглавляемые им службы имели статус юридического лица и самостоятельный бюджет для реализации природоохранной программы города (95).

Природоохранная программа была ориентирована на достижение государственных норм озеленения, которые определялись в зависимости от численности городов. По категории объектов ОП эта норма составляла для крупных и больших городов $10 \mathrm{~m}^{2} /$ чел., а для малых - 7 м²/чел. (96). В 1970 году площадь насаждения ОП в Сургуте составляла 3,9 м²/чел., Лангепасе 1,2 м²/чел., Нижнвартовске - приблизительно 1,5 м²/чел., Нефтеюганске 2,6 м²/чел. (96). Это было существенно меньше установленных государственных стандартов, что делало работу департаментов городов особенно актуальной. 
Они прилагали большие усилия к озеленению городов. Нефтеюганск заметно похорошел после установки вертикальных цветочных вазонов, разбивки клумб и обустройства газонов. Большой блок работ касался планирования благоустройства. Согласно разработанной программе озеленения города, было предусмотрено и осуществлено создание зеленых зон, объединенных в одну систему, заметно улучшающую эстетический вид города. Особое внимание стало уделяться качественному оформлению городских улиц. Вдоль улицы Ленина появилась живая изгородь из кустарников. В городе успешно реализовался проект благоустройства жилых микрорайонов. На его основе был создан парк во 2-м микрорайоне. Администрация города планировала увеличить количества скверов, была продумана система дизайна малых архитектурных форм, велось обновление зеленых насаждений (97).

В Нефтеюганске посредством оригинального метода ландшафтной рубки создавались заданные композиции лесопарковых панорам, формировался необходимый породный состав и пространственная структура насаждений, влияющая на эстетическую ценность и жизнестойкость лесопарковых ландшафтов, улучшающих декоративное качество и лесопаталогическое состояние взрослых деревьев, подроста и подлеска.

Особенностью объектов ландшафтной рубки является то, что ими были отдельные функциональные зоны в рекреационных лесах. Их площадь значительно превосходила площадь жилой и промышленной застройки города, занимавшей всего около $12 \%$, а остальная территория представляла собой болотистую пойменную часть. Город располагался в болотистой местности, и все дома стояли в нем на намывном песке. Еще в 1970- е гг. цветочная клумба здесь была редкостью, и все улицы были засыпаны песочными барханами.

Нефтеюганск всегда поражал своей суперкомпактностью. В годы его становления городские кварталы и промышленная зона были тесно зажаты между берегом реки и магистральными трубопроводами. Узкие улицы, дома тесно примыкали друг к другу, лишали его жителей пространственного обзора и не создавали, как замечали архитекторы, настроения «социального оптимизма».

В 1980-е гг. эти образы начали ослабевать. В данный период Нефтеюганск стал заметно менять свой однообразный облик и очень преобразился, становился более уютным. Ландшафтный дизайн закрыл песчаные пустыни красивыми клумбами и лужайками. В Нефтеюганске исчезали уродливые деревянные постройки в центре города, а на их месте 


\section{ГОРОДСКОЕ СТРОИТЕЛЬСТВО В ХАНТЫ-МАНСИЙСКОМ АВТОНОМНОМ ОКРУГЕ - ЮГРЕ (к.1950-х - сер.1990-х г2.)}

появлялись газоны, площадки для отдыха, кафе, магазины, появилось разнообразие архитектурных стилей.

Земельный кодекс обязывал городской муниципалитет выставлять участки на земельный аукцион для застройки их жилыми домами, что способствовало существенному улучшению вида их палисадных насаждений, облагораживаемых заинтересованными домовладельцами. Хотя при этом следует признать, что индивидуальная застройка в Нефтеюганске должного развития не получила. Намного интенсивнее обустраивался государственный городской комплекс, заметно привлекательнее стала выглядеть городская набережная. 10 февраля 2010 года на историческом месте города, где прежде располагалась его первая «стартовая» городская улица Гагарина, был построен культурно-выставочный зал «Усть-Балык». В нем расположились музейные экспозиции. Сегодня в музее действуют постоянные выставки «Жилой дом 1960-х годов» и «Город, рожденный нефтью», а также организуются сменные экспозиции различной тематической направленности. В настоящее время на этой территории обустроена прогулочная зона с впечатляющим видом на реку Юганская Обь. Деревянные дома, построенные вдоль прогулочной зоны, олицетворяют историческое прошлое города. Строители выполнили большой объем работ: проложили инженерные сети, снесли ветхие дома, а также благоустроили территорию.

Заметно расширилась и похорошела улица Ленина благодаря установке бортового камня. Позже реконструкция коснулась также улиц вокруг 16-16а микрорайонов и главной площади Нефтеюганска.

Согласно утвержденному генеральному плану города Нефтеюганска на 2010-2020-е гг., осуществлялось зонирование территории города, продолжалось благоустройство микрорайонов как зон отдыха, создавались в каждом микрорайоне зеленые скверы, освобожденные от построек и предназначенные для отдыха. Значительное внимание уделялось благоустройству набережной, созданию на ней спортивных площадок (98).

В Нижневартовске зеленых насаждений первоначально также было немного, около 20 га. Они включали два бульвара, сквер и небольшой городской парк, который по размерам и планировке был похож на мини - сквер. Но в планировочном аспекте в исследуемый период в городе были все условия для создания полноценной системы озеленения с равномерным размещением объектов ОП, взаимосвязанных между собой озелененными трассами и бульварами, выходящими к Комсомольскому скверу, вокруг которого после 
проведения гидромелиоративных работ возможно было создать городской парк в естественном лесном массиве с предварительной реконструкцией его насаждений, на что были направлены усилия городской администрации (99).

Что касалось насаждений ОгрП, куда входили озелененные площади внутри микрорайонов: палисадники, дворы, придомные полосы, а также школы, больницы и другие учреждения - дела обстояли лучше, хотя площадь насаждений этой категории и здесь была несколько ниже установленной нормы.

Поэтому неслучайно в 1993 году Сургутской городской думой по инициативе В.А. Браташова была принята первая редакция городской природоохранной программы, которая в 1995, 2000 и 2002 годах подвергалась корректировке. Количество насаждений ОП в ближайшее время должно было составить $10 \mathrm{~m}^{2}$, а в перспективе достичь $20 \mathrm{~m}^{2} /$ чел. По плану озеленения Лангепаса ставилась задача увеличить площадь таких насаждений до $20 \mathrm{~m}^{2}$ на человека.

В этих целях в городах создавались специализированные предприятия: «Росток», «Сургутзеленхоз», «Зеленстрой», «Биоком». Для управления реализацией программы и экологической обстановкой в городах начали формироваться структуры специальных уполномоченных органов в области охраны окружающей среды. В Сургуте, например, к 2003 году она включала в себя Комитет природопользования и экологии администрации города и Департамент имущественных и земельных отношений, МУ «Управление лесопаркового хозяйства», МП «СЦ Природа», МП «НПЦ «Геоэкология» (100).

В условиях севера озеленение строящихся городов представляло собой дорогостоящее предприятие. Себестоимость одного кустарника колебалась от 20 до 41 рубля. Выполнение технологии полного комплекса работ по созданию газона включало в себя завоз торфа, его распределение по площади, посев растительного материала, поливку и ухаживание за растениями, что составляло в денежном выражении 35 рублей за один квадратный метр. Приживались далеко не все растения. Считается, что в центральных районах $20 \%$ посаженного материала должно погибнуть. У специалистов это называется «плановая норма приживаемости». В Сургуте, например, она составляла 35-40\%. Преимущественно высаживали желтую акацию, которая создавала живую изгородь, хорошо защищая от пыли, ветра и шума автотранспорта. Высаживали также сирень, жимолость, березу. Гораздо хуже приживались осина и хвойные породы: сосна, кедр, ель, лиственница. 
Кустарники и деревья в города ХМАО-Югры привозили из Тюмени и Кургана. А цветы выращивали местные умельцы-цветоводы. Это были частные лица, которые квартиры оборудовали под цветочные оранжереи. Департамент по озеленению, природопользованию и экологии заключал с ними соответствующие договоры. Покупка одного цветка колебалась в пределах 5 рублей за штуку. В это время начались работы по созданию собственного питомника в районе кооператива «Интеграл» на площади 15 га (101).

На озеленение города администрация ассигновала значительные средства. Особенно показательно это происходило в Сургуте. В 1996 году сумма финансирования озеленения составила в нем 10000000 рублей, в 1997 году 9500000 рублей. В 1999 году бюджет отдела озеленения, входящего в состав Департамента по озеленению, природопользованию и экологии администрации города составил 19602000 рублей. Из них на создание новых зеленых насаждений было направлено 3533000 рублей, на содержание зеленых насаждений - 8819000 рублей. Остальные средства были направлены на проектирование и строительство парковых зон города, благоустройство его зеленых зон, строительство питомника древесно-кустарных пород и ряд других мероприятий. В 2000 году администрация города выделила на благоустройство и озеленение Сургута 40000000 рублей, в два раза больше, чем в предыдущем году (102).

В эти годы создана система озеленения улиц Сургута, базирующаяся на финансовой и материальной поддержке частных предприятий и активной работе отдела озеленения города в составе Комитета по природопользованию и экологии администрации города. Это было необходимо в связи с тем, что по всем типам зеленых зон Сургут в 1997 году продолжал отставать от нормативов. Если в расчете на одного человека, согласно нормативам, необходимо было иметь $21 \mathrm{~m}^{2}$ насаждений, то фактически на одного сургутянина их приходилось в 2 раза меньше (103).

В 1999 году в зону экологического благоустройства входила 61 улица города, площадь зеленых насаждений которых составляла 125 га, а парковые территории охватывали 25 га (104). Работа по озеленению города Сургута представлена в таблице № 20 (105). 
Таблица № 20

Работа по озеленению Сургута в весенне-летний период 1999 года (кв.м.)

\begin{tabular}{|c|c|c|c|c|c|}
\hline Выполненные работы & $\begin{array}{c}\text { ЗАО } \\
\text { Зеленстрой } \\
\text { «Зеленстрой» }\end{array}$ & $\begin{array}{c}\text { ЗАО } \\
\text { Росток } \\
\text { Росток } \\
\text { «Росток» }\end{array}$ & $\begin{array}{c}\text { ЗАО Сургутзеленхо } \\
\text { «Сургугзеленхоз» }\end{array}$ & $\begin{array}{c}\text { ЗАО } \\
\text { Биоком } \\
\text { «Биоком» }\end{array}$ & Итого \\
\hline Создано новых газонов, м $^{2}$ & 15727 & 23575 & 28357 & 4777 & 72436 \\
\hline Восстановлено газонов, м $^{2}$ & 13202 & 10008 & 37497 & нет & 60637 \\
\hline Посажено деревьев, штук & 1617 & 1207 & нет & 2442 & 5266 \\
\hline Посажено кустарников, штук & 11193 & 8596 & 13932 & 5539 & 39260 \\
\hline Создано цветников, м $^{2}$ & 1505 & 750 & 510 & 1641 & 4436 \\
\hline Высажено цветов, штук & 22570 & 12000 & 10800 & 32820 & 78190 \\
\hline Установлено ограждений, м & 568 & 1164 & 210 & нет & 1942 \\
\hline Создано новых газонов, м $^{2}$ & 15727 & 23575 & 28357 & 4777 & 72436 \\
\hline Восстановлено газонов, м $^{2}$ & 13202 & 10008 & 37497 & нет & 60637 \\
\hline Посажено деревьев, штук & 1617 & 1207 & нет & 2442 & 5266 \\
\hline Посажено кустарников, штук & 11193 & 8596 & 13932 & 5539 & 39260 \\
\hline Создано цветников, м $^{2}$ & 1505 & 750 & 510 & 1641 & 4436 \\
\hline Высажено цветов, штук & 22570 & 12000 & 10800 & 32820 & 78190 \\
\hline Установлено ограждений, м & 568 & 1164 & 210 & нет & 1942 \\
\hline
\end{tabular}

Как видно из таблицы № 20, работа по улучшению экологического состояния улиц города Сургута в 1990-е гг. приобрела широкомасштабный характер. Ее осуществляли на основе хозяйственных договоров с администрацией четыре специализированных предприятия.

В результате их совместной деятельности под руководством В.А. Браташова площадь зеленых насаждений улиц, парков и скверов в 1993-2001- гг. увеличилась на 170 га (106).

Анализ проведенного в 2000 году социологического исследования показал, что сургутяне считали благоустройство и озеленение самой значительной работой, проведенной администрацией города за последние пять лет (107).

Таким образом, в исследуемый период администрация строящихся городов Ханты-Мансийского автономного округа ХМАО-Югры прилагала максимум усилий по созданию благоприятной креативной обстановки в новых 
населенных пунктах. Предметом особой заботы руководителей городов и их общественности являлась экологическая обстановка в местах проживания югорчан. В комплексе решаемых вопросов центральное место занимала проблема питьевой воды. Благодаря отечественным и приглашенным зарубежным специалистам в городах Югры удалось внедрить современные системы и технологии ее очистки и обеспечить качество питьевой воды, соответствующее в целом по большинству показателей санитарногигиенических норм.

Важным побудительным мотивом проведения эффективной экологической политики в городах Среднего Приобья являлось их расположение на территории, опасной для здоровья человека и особенно усилившей свою враждебность в результате технологического влияния на ее среду.

Необходимость нейтрализации этой опасности, сохранения природной среды, особенно в городах с особой уязвимостью таежных лесов, диктовало проведение в них масштабных рекультивационных работ. Принимаемые администрацией программы озеленения были связаны с большими экономическими затратами, но они выполнялись и имели значительный эффект. В Сургуте доля ПДК по взвешенным частицам сократилась с 0,9 в 1993 году до 0,5 в 2001 году. Тем самым превышение ПДК по взвешенным веществам в нем практически исчезло. В 2000 году площадь зеленых насаждений в пределах городской застройки составила уже $42,6 \%$ eе территории. Уровень обеспечения населения зелеными насаждениями увеличился до 50,7\%, что превышало нормативы более чем в 2 раза (108).

По итогам Всероссийского конкурса «Самый благоустроенный город России», в котором оценивалась деятельность администрации по благоустройству, вводу жилья и состоянию коммунальной сферы, города ХМАО неизменно занимали достойные места в своих номинациях, а Сургут в 1999 году был признан четвертым среди 370 городов с численностью свыше 100 тыс. чел. (109).

\section{Примечания}

1. Баталин Ю.П. От игр в «кубики» к суперблокам // Соратники. Поколение Виктора Муравленко. Тюмень, 2002. С. 79.

2. АОАГС. Ф.1.On.1. Д. 150. Л.9; Ф. 1.On.1. Д.25.Л.17. 
3. Особенности градостроения в нефтяных районах Тюменской области. Л., 1972. С. 90.

4. ГАСПИТО.Ф.113.Оп.16.Д.1.Л.16.

5. АОАГС. Ф.1.Оп.1.Д.131.Л.6.

6. Мунарев П.А. Так было, так начиналось. (Записки председателя). Сургут, 2008. С. 74.

7. Там же. С. 74-75.

8. АОАГС.Ф.1.Оп.1.Д.144.Л.6.

9. ГАСПИТО. Ф.124. Оп.182. Д.18. Л.7.

10. Мунарев П.А. Указ. соч. С. 75.

11. Там же.

12. АОАГС. Ф. 1. Оn. 1. Д. 156. Л.2-3.

13. ГАСПИТО. Ф.113. Оп.27. Д.28. Л.16.

14. Там же. Л.5.

15. Мунарев П.А. Указ. соч.

16. АОАГС. Ф.3. Оп.1. Д.5. Л.92-93.

17. Мунарев П.А. Указ. соч.

18. АОАГС. Ф.З. Оп.1. Д.10. Л.101.

19. АОАГС. Ф.З. Оп.1. Д.38. Л.194.

20. Новый город. - 1999. - 19 октября.

21. Там же.

22. Там же.

23. Краеведческий календарь. Политические даты Сургута на 2003 год. Сургут, С. 13.

24. К победе коммунизма. 1960. 2 сентября.

25. АОАГС. Ф.1. Оп.1. Д.144. Л.14.

26. СПОПАТовец. С. 1.

27. АОАГС. Ф. 1. On. 1. Д. 134. Л.9.

28. АОАГС. Ф.З. Оп.1. Д.14. Л.194.

29. ГАСПИТО. Ф.113. Оn. 16. Д.42. Л. 12.

30. АОАГС. Ф.3. On.1. Д. 14. Л.194.

31. ГАСПИТО.Ф.113. On.16. Д.42. Л. 12.

32. АОАГС. Ф. 1. On. 1. Д.142. Л. 10.

33. АОАГС. Ф. 1. On.1. Д. 144. Л.142.

34. АОАГС. Ф. 1. On.1. Д. 10. Л.70.

35. АОАГС. Ф. 1. Оп.1.Д.150.Л.9. 
36. АОАГС. Ф.1. Оп.1. Д.144. Л. 7

37. Там же

38. АОАГС. Ф.3. Оп.1. Д.5 Л.93

39. ГАСПИТО. Ф.113. Оп.16. Д.1. Л. 215

40. ГАСПИТО. Ф.113. Оп. 21. Д. 53. Л.14

41. К победе коммунизма.1960. 2 сентября.

42. К победе коммунизма. 1961. 3 февраля.

43. АОАГС. Ф.3. Оп.1.Д..28.Л.10, 11.

44. Там же. Л.10.

45. СПОПАТОВЕЦ. С.1.

46. ЛЕТ СПОПАТ. Буклет.

47. Таблица составлена по материалам: ГАСПИТО. Ф.113. Оп.227. Д.28. Л.6.

48. Там же.

49. Там же. Л.

50. Там же.

51. Сургут. Городское хозяйство. Транспорт и связь. Сургут. 2001.С.15.

52. Ханты-Мансийский автономный округ // Научно-информационная энциклопедия «Вода России». Интерактивный образовательный портал. Режим доступа: http water,rf /Регионы/25 57 / Ханты-Мансийский округ.

53. Гребенюк Н., Вавер О.Н. Указ.соч. С. 30.

54. Обзор состояния окружающей среды города Сургута 1993-2002 гг. Сургут, 2003. С.83

55. АОАГС. Ф.1.Оп.1.Д.144.Л.18.

56. ГАСПИТО. Ф.Ф.113Оп.16.Д.19.Л.9.

57. Там же. Л.9, 48.

58. ГАСПИТО.Ф.113.Оп.191.Д.22.Л.15.

59. ГАСПИТО.Ф.113.Оп.19..40.Л.58.

60. АОАГС.Ф.3. ОП.1. Д.54. Л.98.

61. ГАСПИТО. Ф.113.Оп.23. Д.7. Л.150.

62. Мунарев П.А.Указ. соч. С.34.

63. Новый город. 2011. 12 февраля. С.9.

64. ГАХМАО.Ф.387. Оп.1. Д.286.Л.10.

65. Сургутские ведомости. 2006.16 декабря.

66. ГАХМАО.Ф.387.Оп.1.Д.286.Л.10.

67. Сургутская трибуна. 2001. 2 февраля. 
68. Режим доступа: muksun.fm 11 августа 2020

69. Солодовников А.Ю., Солодовников Д.А. К вопросу о качестве питьевой воды в Нефтеюганском районе // Вестник Тюменского государственного университета. Экология и природопользование. 2016. С.23.

70. Там же. С.25.

71. Там же. С.23.

72. Вестник. 1998. 15 июня.

73. Там же.

74. Сургутские ведомости. 2006. 16 декабря.

75. Там же.

76. Вести СТС. 2001. 12 марта.

77. Сургутская трибуна. 2001. 11 января.

78. Вести СТС. 2001.12 марта.

79. Там же.

80. Там же.

81. История и перспективы градостроительного освоения... С.64-65.

82. Там же.

83. Шмаль Г.И. Юность комсомольская моя. Из воспоминаний Г.И. Шмаля // История и перспективы градостроительного освоения территории Севера. - М., 2004. - С. 185.

84. Югра.2000.Июнь. С.31.

85. Сургутская трибуна.1995.12 мая.

86. Экологическая газета.1997.№3

87. Табл. сост. по материалам: Обзор состояния окружающей среды города Сургута. 1993-1998 гг. Сургут, 2003. С.94.

88. Там же. С.94-95.

89. Новый город.2003. 10 июля.

90. Там же.

91. Новый город.1997.28 сентября.

92. Новый город.1999. 28 сентября.

93. Югра.2000.Июнь. С.30.

94. Обзор состояния окружающей среды города Сургута 1993-2002 гг. Сургут, 2003. С.120.

95. Там же.

96. Режим доступа: http://depprirod.admhmao.ru deyatelnost/na/yanvaraja 2019 goda 
97. См.: Сродных Т.Б, Денеко В.Н., Чикурова А.Ю. Озеленение городов Среднего Приобья //Леса Урала и хозяйство в них. Сб. научн. работ. Екатеринбург, 2003.С.238-245.

98. Неприенко П.Г. История культурных ландшафтов города Нефтеюганска // Режим доступа: school-science.ru 5/ 2/ 35847

99. Сродных Т.Б, Денеко В.Н., Чикурова А.Ю. Озеленение городов Среднего Приобья // Леса Урала и хозяйство в них. Сб. научн. работ. Екатеринбург, 2003. С.238-245.

100. Обзор состояния окружающей среды города Сургута 1993-2002 гг. C. 120 .

101.Сургутская трибуна. 1997. 11 июня.

102. Югра. 2000. Июнь. С. 30.

103. Обзор состояния окружающей среды города Сургута 1993-2002 гг. C. 120 .

104. Экополис. Экологическое приложение к газете «Сургутская трибуна». 2000. Январь. Вып. 1.

105. Таблица составлена по материалам: Экополис. Экологическое приложение к газете «Сургутская трибуна». 2000. Январь. Вып. 1.

106. Экополис. Экологическое приложение к газете «Сургутская трибуна». 2000. Январь. Вып. 1.

107. Югра. 2000. Июнь. С. 30.

108. Обзор состояния окружающей среды города Сургута 1993-2002 гг. С. $80,120$.

109. Вестник СТС. 1999.14 июня. 


\section{ЗАКЛЮЧЕНИЕ}

Подводя итог размышлениям об истории строительства городов Ханты-Мансийского автономного округа - Югры, хочется еще раз подчеркнуть её уникальный характер. Несомненным является то, что принятая в свое время модель «внутреннего расселения» доказала свою эффективность и масштабное строительство «нефтяных городов» явилось надежной основой промышленного и социального освоения крупнейшей нефтегазовой территории России.

Градостроение на севере Западной Сибири было сопряжено с огромными трудностями преодоления враждебности окружающей среды, создания проектно-изыскательских вариантов домостроения, ранее не существовавших в мировой практике строительства городов, разработке строительных норм, ранее не применяемых в условия заболоченности и экстремально низких атмосферных температур.

Кроме природного фактора, существенное торможение целостной и системной застройке городов Ханты-Мансийского автономного округа - Югры оказывала командно-административная система управления строительством с характерным для нее ведомственным, «хуторским» принципом, который, как правило, отторгал единого генерального проектировщика, заказчика и подрядчика, представительство государственного архитектурного надзора. Решающую центростремительную роль в этой стихии первоначального накопления градостроительного опыта сыграли местные партийные комитеты и подвластные им городские и районные исполнительные комитеты народных депутатов.

В силу своих возможностей автор попытался показать весь масштаб проделанной градообразующей работы, связанной с созданием строительной отрасли на севере Западной Сибири, и роль в этом процессе таких ярких руководителей региональной проектно-архитектурной работы и индустрии домостроения, как А.С. Барсуков, Ю.П. Баталин, С.В. Билецкий, Г.М. Кукуевицкий, В.И. Унжаков, С.В. Бешкильцев, А.Н. Отраднов, и других участников подвижнической работы, совершивших свой трудовой подвиг в такой немыслимо короткий срок.

Хочется надеяться, что изучение этой истории будет способствовать дальнейшему успешному социально-экономическому освоению Западной Сибири и продвижению России за полярный круг, в неизведанные пока в полной мере арктические просторы нашей необъятной Родины. 


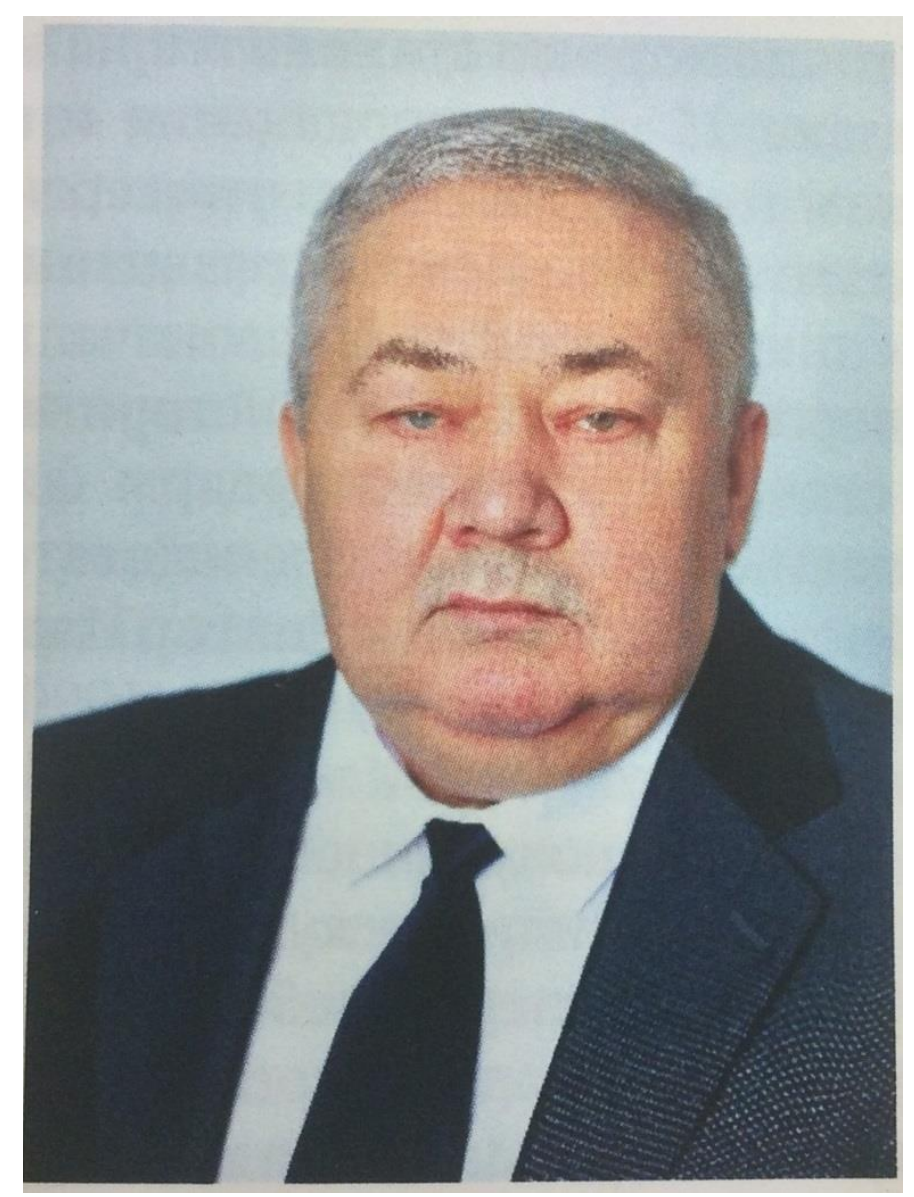

Сведения об авторе.

ПРИЩЕПА АЛЕКСАНДР ИВАНОВИЧ, в 1976 г. окончИЛ исторический факультет Уральского государственного университета им. А.М. Горького, д.и.н., профессор, Почетный профессор Сургутского государственного университета ХМАО - Югры, Заслуженный деятель науки Ханты-Мансийского автономного округа - Югры, Почетный работник Высшего профессионального образования Российской Федерации.

Автор 8 монографий и 300 научных публикаций. 
НАУЧНОЕ ИЗДАНИЕ

Прищепа Александр Иванович

\section{ГОРОДСКОЕ СТРОИТЕЛЬСТВО В ХАНТЫ-МАНСИЙСКОМ АВТОНОМНОМ ОКРУГЕ - ЮГРЕ}

(к.1950-х - сер.1990-х гг.)

\section{Монография}

Подписано в печать 01.02.2021 г.

Формат 60x84 1/16. Усл. печ. л. 12,85.

Тираж 500 экз.

МЦНП «Новая наука»

185002 , г. Петрозаводск

ул. С. Ковалевской д.16Б помещ. 35

office@sciencen.org

www.sciencen.org

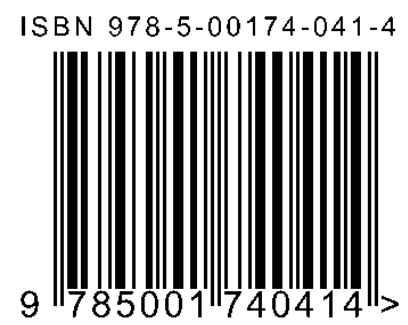

